
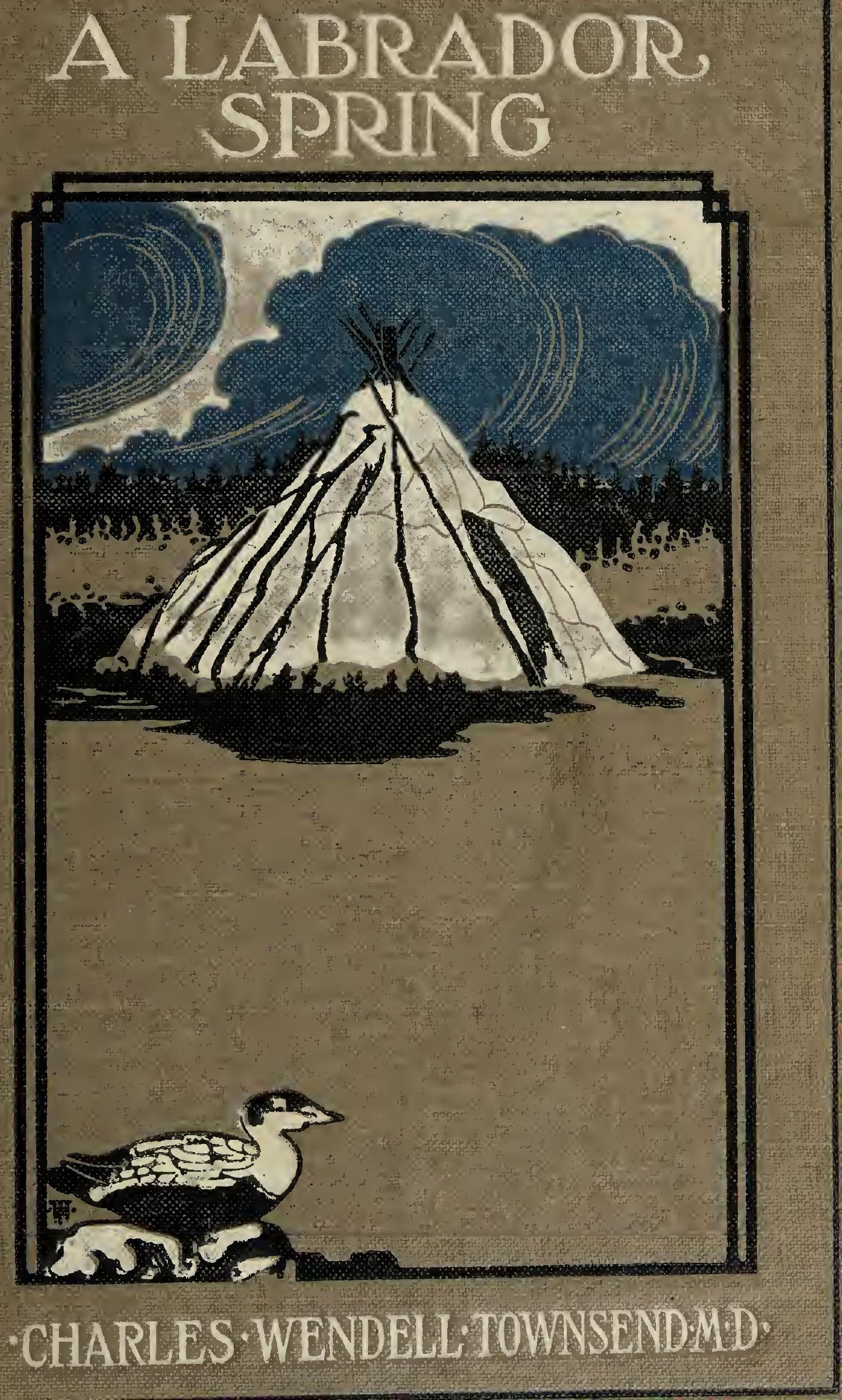


A Labrador Sprin\& 
Digitized by the Internet Archive in 2019 with funding from Kahle/Austin Foundation

https://archive.org/details/labradorspring0000town 



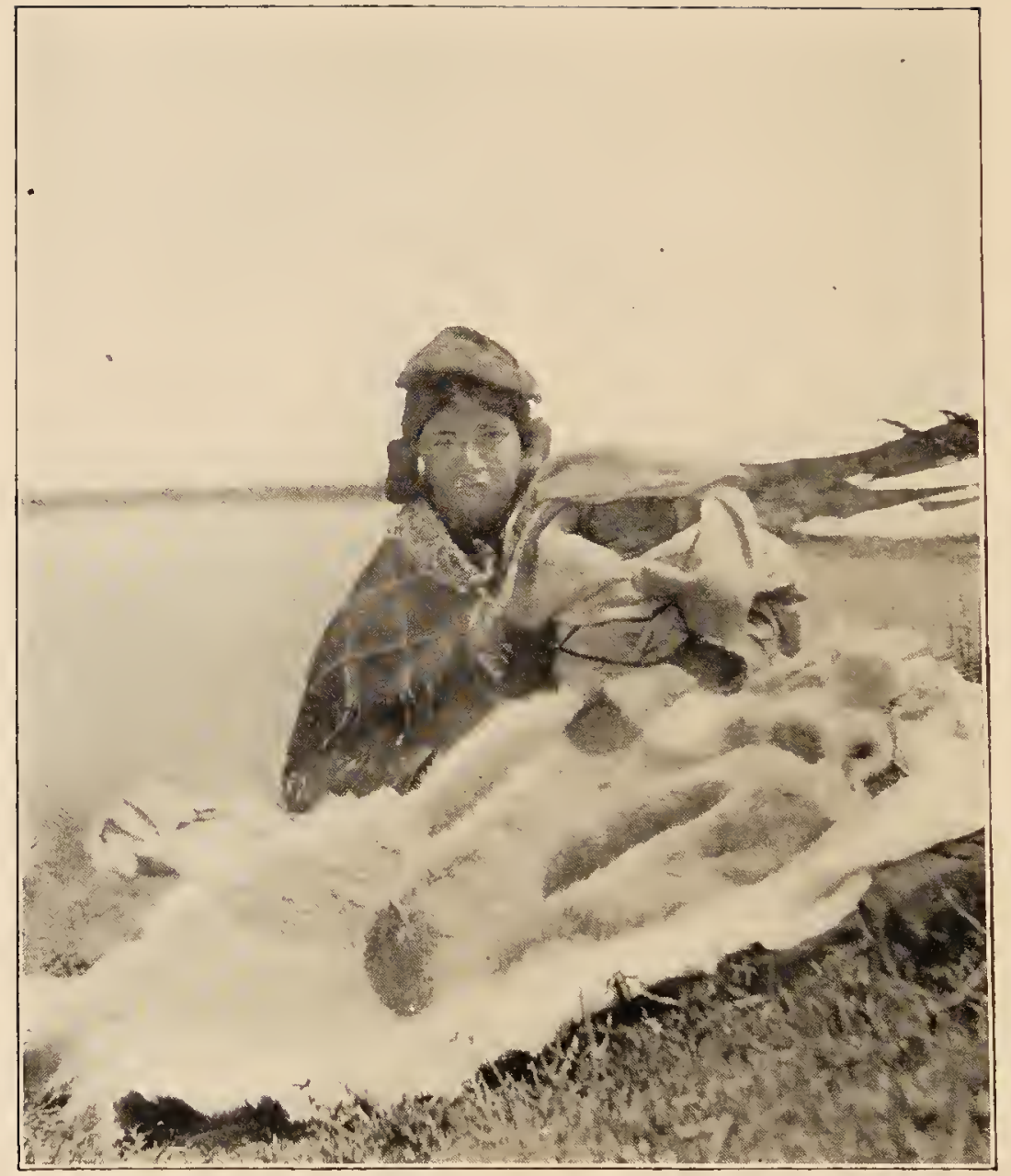

AN EARLY SPRING ARRIVAL IN SOUTHERN LABRADOR.

Frontispiece 


\section{A LABRADOR SPRING
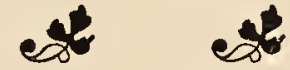

\section{BY \\ CHARLES W. TOWNSEND, M. D. \\ Author of "Along the Labrador Coast," etc.}

With Illustrations from Photographs

$$
\begin{aligned}
& \text { BOSTON DANA ESTES \& } \\
& \text { COMPANY MDCCCCX }
\end{aligned}
$$


Copyright, sqro

By Dana Estes \& Company

All rights reserved

Electrotyped and Printed by THE COLONIAL PRESS

C. H. Simonds \& Co., Boston, U.S.A. 


\section{Preface}

President Lowell in his inaugural address said to the professional man that "a firm grasp of some subject lying outside of his vocation is an advantage." The following chapters are the result of a five-weeks' trip in May and June, I909, by one who tries to live up to this advice. Although that subject, as may be gathered from these chapters, is ornithology, yet it may also be gathered that all branches of natural history on this Labrador coast were a delight to the writer, and that human studies, both Indian and white, came in for a full share of his observations. And perhaps this is well, for, as Professor Shaler said, "the most of our kind are not naturalists but humanists." In any event it is hoped that the following lines, which have been used by the Harvard Travellers Club, are appropriate: 


\section{PREFACE}

"He traded not with luker sotted, He went for knowledge and he got it."

The substance of Chapter VIII originally appeared in two papers published in the Auk in April and July, I909, and part of Chapter IV, in the $A u k$ of April, I 9 IO, and I am indebted to the editor for permission to republish in this form. I wish to express my thanks to Professor M. L. Fernald and Mr. Walter Deane for botanical identifications, to Prof. E. C. Jeffrey and his assistant Mr. E. W. Sinnott for the photograph of the little larch and the photomicrograph of its cross-section, and particularly to Mr. A. C. Bent for some of the illustrations and for his companionship in this Labrador Spring. 


\section{Contents}

CHAPTER

PAGE

PREFACE . . . . . . . . .

I. A Labrador SPring . . . . . . I I

II. From Seven Islands to Esquimaux Point 36

III. An Acadian Village . . . . . 64

IV. The Courtships of Some Labrador Birds 83

V. The Cruise of " La Belle Marguerite" from Esquimaux Point to Natashquan io3

VI. Three Modern Cartwrights . . . I 30

VII. The Montagnais Indians . . . . . I 49

VIII. Wings AND FEET IN THE AIR AND UNDER

WATER . . . . . . . I 80

IX. Some Labrador Trees . . . . . 206

X. Some Labrador Rivers . . . . . 220

INDEX . . . . . . . . $25 \mathrm{I}$

vii 



\section{List of Illustrations}

PAgr

An Early Spring Arrival in Southern Labrador

(See page 157)

Frontispiece

Mountain Saxifrage on Limestone Cliffs of Esguimaux Island •

Nearer View of the Mountain Saxifrage . . I7

Snowbank and Vegetation June 4 . . . . 30

Snowbank and Vegetation June I3 • . . 30

Indian Mother and Ten Days' Old Infant . . 37

The Town of Seven Islands . . . . . 37

Hudson's Bay Post of Mingan. Mountain Ridge

in the Distance • . . . . . . 45

The Barrier Mountain Ridge Back of Mingan

Showing Poised Boulder . . . . . 45

The Best Hunter of the Tribe, Just Back from

the Northwest River . . . . . . 50

A Montagnais Couple at Mingan . . . . 50

Indian Mother and Child at Mingan . . . 60

Toadstool-shaped Limestone Rocks at Esqui-

MaUX ISLE . . . . . . . . . . 60

Preparations for the Fishing Season . • . 73

The Procession at the Feast of Corpus Christi

at Esquimaux Point . . . . . . 78 


\section{LIST OF ILLUSTRATIONS}

PAGB

Raising the Host at the "Repository" . . 78

Returning to the Church of St. Pierre at the

Feast of Corpus Christi . . . . . 82

Nest of Great Black - Backed Gull . • . 86

Nest of Eider Duck . . . . . . . . 86

Entrance to Puffin Burrow, Bald Island • • 96

Water Worn Limestone Rocks at Bald Island.

Nesting Shelves for Razor - billed Auks • 96

" La Belle Marguerite" and Our Gallant Crew I05

Mathias and Martial and the Beaver. • . II 5

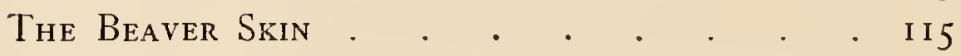

A Corner of a Cormorant Rookery at Seal Rock 125

Nest and Eggs of Double - crested Cormorant . I25

A Black Fox Park at Piashte - Bai . . . i36

Piashte - Bai River and Lake from the Beginning

of THE High LAND OF THE INTERIOR • . I36

Three Little Indian Girls . . . . . I 43

Two Montagnais Companions at Mingan • . I 43

Indians Shaving Seal Skin at the Isles des Cor-

NEILLES . . . . • . • . I54

The Papóose . . . . . . . . . 154

Wigwam in Process of Construction at Mingan I57

Completed Wigwam . . . . . . . I 57

Wigwam and Indian Family at Piashte - Bai • 159

INDIANS AT THE Isles DES CoRneIlles • • • I59

Loading the Canoe . . . . . . . . . $16_{3}$

The Embarkation of the Montagnais at Natash-

QUAN FOR MUSQUARRO . . . . . . . I63

Our Host, the Salmon - Fisher at Mingan, and

His Old Companion . . . . . . 170 


\section{LIST OF ILLUSTRATIONS}

Mr. J. A. Wilson, Factor at the H. B. C. Post at Mingan, on the Steps of the Company's House Built by Mr. Donald Alexander Smith, now Lord Strathcona and Mont Royal . i7o The Last Leaf on the Tree, Said to be iO4 Years

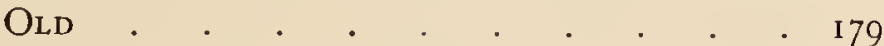
My Escort among the Indians at Mingan . . 190 Pierre of Piashte - Bai and the Beaver, Showing

Webbed Hind Foot of the Beaver, and "SKIN Boots" of MaN . . . . . . 197

Divarfed Spruces Dead and Alive at Esquimaux ISLAND • • • • • • • • • • 205 Ancient Larch at Quatachoo . . . . . 205 Larch Tree Sixteen Years Old, from Bog at

Esquimaux Island; Slightly Enlarged . . 2 II Photomicrograph of Section of Trunk Showing

Sixteen Annual Rings . . . . . . 2 II

The Old Salmon-fisher of Mingan Tending

His Nets . . . . . . . . 22I

The Mingan River Back of the H. B. C. Post . 227 Nest of the Pigeon Hawk . . . . . . 227 Falls of the Mingan . • • . • • . 235

The Romaine River North of Esquimaux Point 235

Falls of Piashte - Bai River . . . . . 243

Near the Foot of the Falls . . . . . 243

Bog Encroaching on Pool and Forest EncroachING ON BOG . . . . . . . . . . 248

Spruce Forest, Snow - bank and the River of the

CROW . . . . . . . . . . 248 



\section{A Labrador Spring}

\section{CHAPTER I}

\section{A LABRADOR SPRING}

"Come, gentle Spring, ethereal Mildness, come." - Thomson.

SOME years ago in Labrador in late July, I was interested to see within the space of a few yards all stages of the seasons from mid-winter to mid-summer. In the shelter of a rugged cliff was a snow-drift as white and devoid of life as winter itself. At its edge, for the space of a few inches, the ground was bare and brown; grasses and procumbent willows showed no evidence of life. A little further away the first signs of spring were visible in the swelling buds of the willows; a few feet further and one came on the bake-apple and Labrador tea in bud; still further removed in space from grim winter, they were as much in blossom as in mid-summer, while at a distance of 


\section{A LABRADOR SPRING}

three or four yards more, the ripening berries of autumn could be found. Here was no need of long journeys to pass from winter to summer, nor of long tarrying in one place for the seasons to pass. The melting snow-drift, the brief spring and the short arctic summer condensed all the seasons in space and time.

Spring is a long process in New England. From the first appearance of the blue-bird and skunk cabbage in early March or even in late February, to the departure of the last black-poll warbler for the north and the falling of the apple blossoms in early June, spring dallies along the way for over three months. Not only does spring dally in this temperate region, but, in its early progress, it sustains frequent interruptions - eruptions one might call them if that hot word can be used in a cold sense - of winter.

I have always longed to watch the arrival of spring in the country, but to absent oneself from one's duties for over three months is plainly out of the question. The northern spring, however, has its advantages in these hustling times; it is a hustler itself. The change from mid-winter to mid-summer is so 


\section{A LABRADOR SPRING}

brief that northern regions are said to have no spring. The whole glorious ecstasy of bursting buds and migrating birds is concentrated into the space of a few weeks or even days. As the bake-apple springs into flower when the snowbank melts, so does spring burst upon the scene in these regions when winter departs.

It was with great eagerness therefore that I explored the country on my arrival at Esquimaux Point in southern Labrador on May $24^{\text {th }}$ for signs of spring, fearing that I might be too late, and that the summer had already come. Fortunately it was a tardy season and all was still wintery. Cartwright in his Labrador journal of May 21, I77I, one hundred and thirty-eight years and three days before, made this record: "The first green leaf appeared to-day, which was a currant." I found

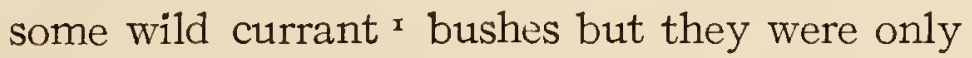
in bud and the leaves did not appear until a few days later. The alders still kept their buds closed, but they had already begun to hang out their "golden curls," and the yellow

${ }^{1}$ The scientific names of the birds and plants will be found in the Index after the common names. 


\section{A LABRADOR SPRING}

pollen floated on the pools of water that came from the dwindling snowbanks. Snowbanks were everywhere, the largest often on the warmest or southern slopes, a paradox that could be explained by the fact that in the southern lees, the snow, driven by the prevailing northerly gales of winter, had accumulated to great depths, and, although exposed to more sunlight, took longer to melt than did the smaller banks on the wind-swept northern exposures. The larch and the canoe birch, the mountain ash, and the red osier were all bare and wintery, but on the ground an occasional fresh grass blade, or the bud of the cow parsnip, - Cartwright's "alexander," - could be found.

The presence of such arctic birds as snowbuntings, making the green spruces look like Christmas trees when they perched on their branches, added to the wintery aspect of the scene, and although the hardier summer birds like the robin, fox sparrow, Lincoln's sparrow, white-throated and white-crowned sparrows had arrived and were in full song, most of the summer residents were still tarrying farther south, and had been passed during our more 


\section{A LABRADOR SPRING}

rapid railroad migration to the north. I breathed a sigh of relief at the result of this hasty survey of the situation, for I had arrived in time, and in the next four weeks I was to be present at the rapid change from winter to summer, at the miracle of the Labrador spring.

Although there were no fresh green leaves to be seen, there was no absence of this colour in vegetation, and it was not limited to the cone-bearing trees to which the name evergreen is usually limited. These latter are quickly enumerated, namely the black, white and a few red spruces, the balsam fir and two kinds of ground juniper, for there were no pines in this region, and spruce and fir were by far the prevailing trees. On the ground of the bogs or barrens, which extend their vegetation into the spruce forests, the universal sphagnum moss as well as many other mosses were evergreen. As the various lichens which abound in Labrador assume every colour of the rainbow, some of these also were green. Clumps of pitcher-plant leaves were everywhere in the bogs, looking often as fresh and intact as if they had been preserved in a green-house, instead of lying buried 


\section{A LABRADOR SPRING}

under the snow for seven long months. Many of these, however, merged from green to red, to magenta and deep mahogany colour. The dark green shining leaves of the goldthread also came out intact from the cold storage of winter, and the laurel and Labrador tea formed great clumps of colour which shaded off from pale olive green to dark brown. Another abundant evergreen in the bogs was the cassandra or leather-leaf, pale green and silvery in colour with drooping leaves, while the andromeda, undismayed by the long winter, carried its dark green, narrow leaves erect. These last two and the laurel were in full blossom by the end of the third week in June, but now were blossomless.

In the woods the dwarf cornel came out from the winter with leaves intact, but blushing deep red, while, forming a carpet with its tiny green leaves and running branches, was everywhere the snowberry, appropriately called chiogenes, or born of the snow. Another broad leaf evergreen to be found especially on gravelly open places near the shores, and one which, prone on the ground, spread like great mats over several square feet of surface, 


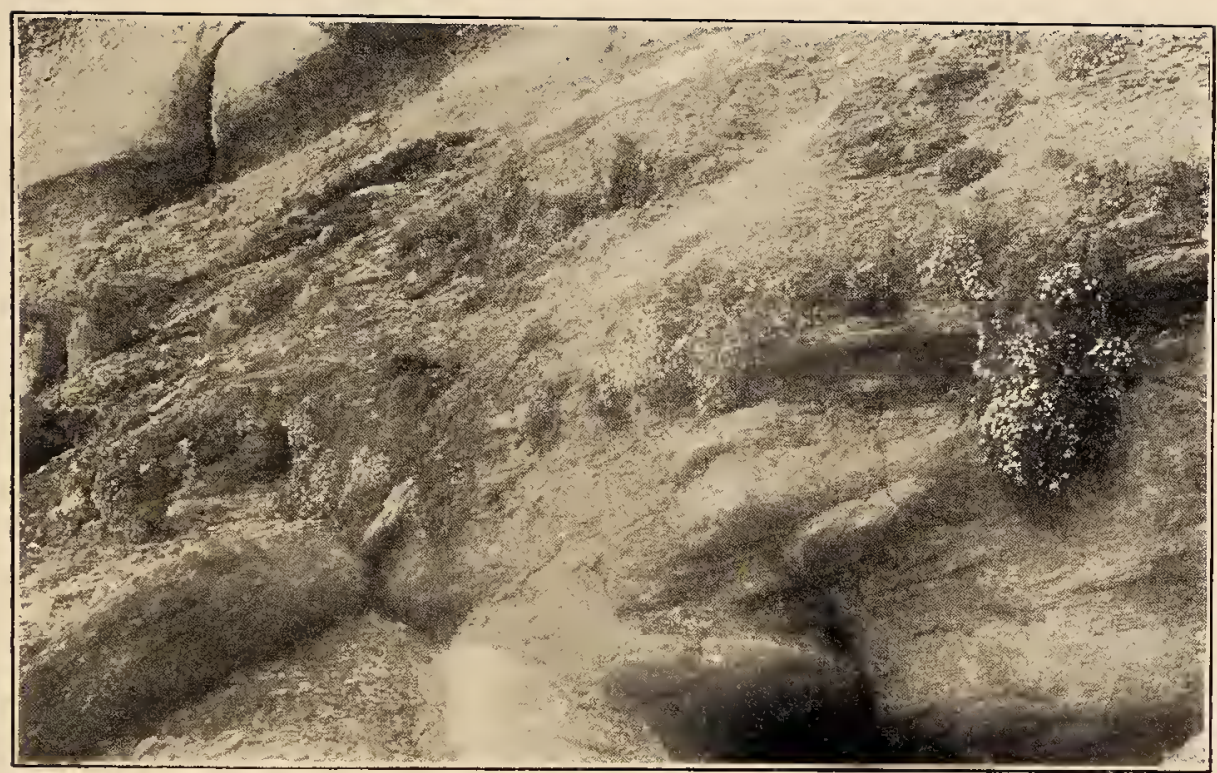

MOUNTAIN SAXIFRAGE ON LIMESTONE CLIFFS OF ESQUIMAUX ISLAND.

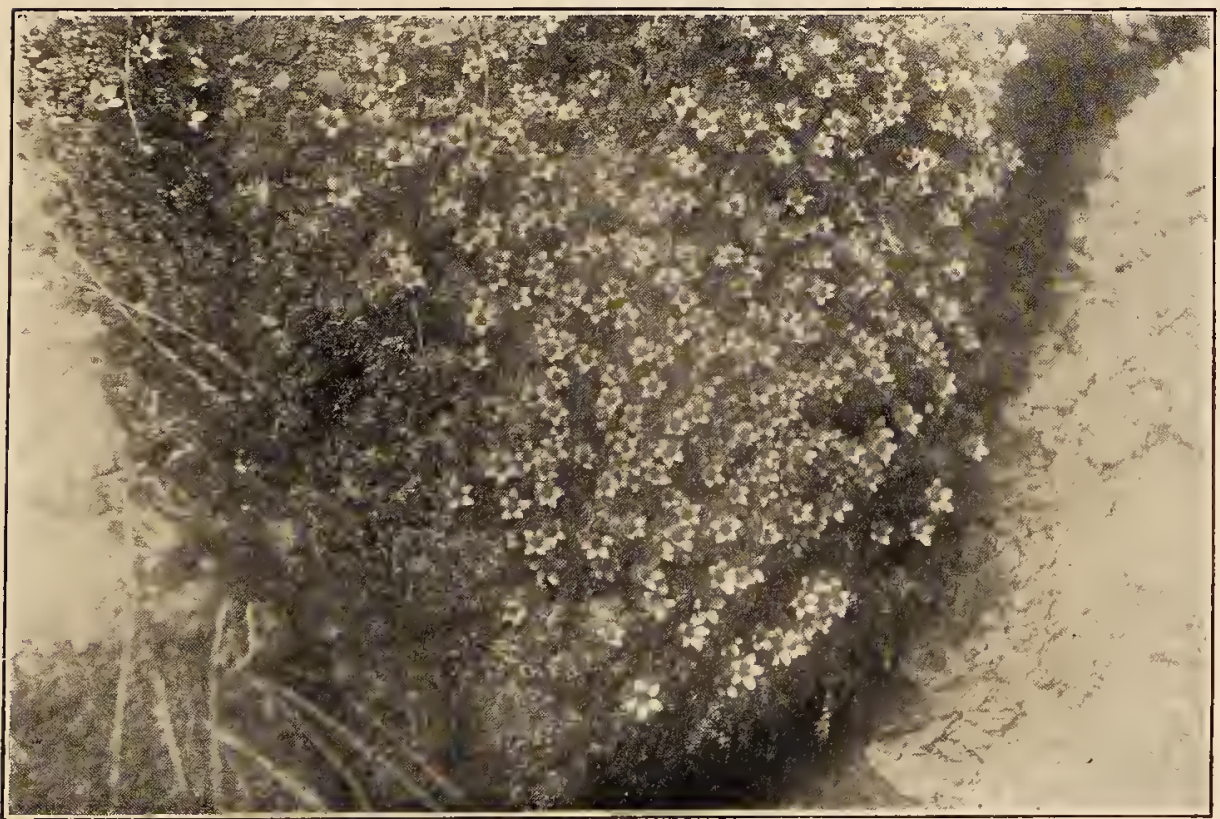

NEARER VIEW OF THE MOUNTAIN SAXIFRAGE. 



\section{A LABRADOR SPRING}

was the bearberry. This also came into flower before we left.

Although not a new leaf bud had opened, there was one conspicuous exception to the flowerless vegetation, and this was the mountain saxifrage which grew in great abundance on the limestone cliffs of Esquimaux Island. It is a tufted moss-like plant, the leaves evergreen and inconspicuous, but the flowers, of a wonderful shade of pink, so crowded the ends of the short stems that they formed glorious masses of colour, hanging in festoons from the cliffs or studding the rocks in great bosses. It was in full flower when we first discovered it on May $25^{\text {th, }}$ and it exhaled a fragrance like that of the trailing arbutus, but much more delicate.

Another sign of spring was the continued trilling of toads which greeted my ears that first evening at the Pointe aux Esquimaux, a sound which is always associated in my mind with pussy willows and a brown, wet countryside, but with the glorious promise of bright flowers, migrating birds and the coming of summer. Although this sound is at times almost overpowering in its intensity in New England 


\section{A LABRADOR SPRING}

where toads abound, it is rarely noticed except by the initiated, and to those who have not consciously heard it, it is rather difficult to describe. Gadow speaks of this love-song of the toad, for love-song it certainly is, as "a peculiar little noise, something like the whining bleat of a lamb." As most people appear to be deaf to the bird notes and even bird songs that may actually fill the air about them, so are they also, but to an even greater degree, deaf to this humble music of the toad; a song which, from its association with the season at least, has its charms. The louder and better known notes of the hylas were absent on these shores.

In these northern regions spring advances by bounds, and the saying that "nature never makes leaps" was certainly contradicted by an experience on the eleventh day of June. On this day, while we were eating our dinner on the banks of the Romaine River, enjoying the wonderful beauty of the scene, listening to the undertone of the rapids and the incisive song of the redstart, and breathing in the aromatic, incense-like perfume of the alder catkins, a birch, released by the melting 


\section{A LABRADOR SPRING}

of the snow, suddenly leaped up to greet the sun. It was still bare as in winter, but in a few days it would be clothed with the fresh green that its recently escaped companions had already assumed.

Birches and especially alders accommodate themselves to the winter snows, and submissively bend before them, but with the coming of summer their bonds melt away and they arise unharmed from their supine position. In this winter pressure the birch very rarely breaks, the alder, almost never. Not so the spruce, the larch and the fir, and green-stick fractures of these trees abound, and sometimes in the lee of a bank where the snow settles in deep, heavy masses, these trees show the scars of many winters by a series of partial breaks. In some of these the trunk assumes a position at right angles with its original growth, and parallel with the ground; in other cases the trunk points downward at first, but in any event, unless fatally wounded, the tree again aspires, only to be beaten down again perchance in another winter. Around the breaks calli in the form of rounded masses of wood form just as they do about 


\section{A LABRADOR SPRING}

broken bones, until the tree presents a woefully crooked and crippled appearance. One of these warty calli as big as a man's head was shown me at Natashquan, where it had been preserved as a curiosity. The difficulties of Labrador tree-life are great!

Perhaps the most active week in this brief spring drama was that of the third to the tenth of June. On the third I found white violets covering a sunny bank hitherto bare, while a few marsh marigolds, their bright yellow flowers contrasting well with their dark, almost black leaves, appeared on the edges of a brook fed by a snowbank. Near by a few ferns were pushing up their "fiddle-heads" from the rich mould, and the cow parsnip was sending up its buds of folded leaves beside the gigantic dead stalks which had survived the winter storms. The dwarf willows and birch were trying to show green in their leaf-buds, and the larger buds of the mountain ash were slowly unfolding. On the next day I found the first white flower of the goldthread, and on the fifth the currant, the first shrub to leaf out, was in blossom.

June $7_{\text {th }}$ was a red letter day in the spring calendar. The red osier, hitherto so bereft 


\section{A LABRADOR SPRING}

of foliage, but noticeable by its red and green stems, began to thrust out its opposite, pointed leaf-buds, canoe birch leaves were half out, the fiddle-heads were unfolding, and, like magic, groups of tiny orchids had sprung into being. This orchid, a calypso, with its broad, rounded leaf rose two or three inches from the moss, each plant bearing a single flower, a five rayed one, between pink and purple in colour, with a brilliant gold spot on the delicately veined lip. One is apt to associate orchids with tropical or at least warm climates only, but this little orchid extends its range from Labrador to Alaska. Near where I first found this orchid on Esquimaux Island, there were numerous arrivals among the birds, for the night before had been a favourable one for migration, and small birds that feed by day must of necessity use the night for migration. The association of orchids, spruce forests, snowbanks, magnolia warblers and redstarts certainly seemed an unusual one, and I satisfied my enjoyment of the incongruous by following a redstart until his brilliant red and black plumage was set off by a background of dark spruces and white snow. 


\section{A LABRADOR SPRING}

Another flower, almost as charming as the orchid, I found for the first time on this day, springing up from its procumbent mass of dark, evergreen foliage, the mountain avens or dryas, a rock nymph rather than a wood nymph, however, for it grew on the scanty soil of the limestone ledges close to the sea. The leaves are arrow-head shaped, dark, shining green above, white below, while the flowers, growing in abundance on short erect stems, open their lovely white cups, like single roses, to the sky. Where the buds of these conspicuous flowers were hidden but a week before, I do not know, although I had collected and pressed this pretty evergreen without even suspecting that it would be covered with conspicuous flowers a week later. The mountain avens extends its range through arctic America even to Greenland.

Another exceedingly pretty little flower, a lilac coloured one, that sprang up on the limestone rocks at this time, was especially noticeable on account of its leaves which were covered with a white powder below. This was a variety of the mealy primrose, and, curiously 


\section{A LABRADOR SPRING}

enough, this variety had never been found east of the Rocky Mountains before.

As in the Doone valley so here in Labrador the words of John Ridd were appropriate, for " the spring was in our valley now, creeping first for shelter slyly in the pause of the blustering wind. ... There she stayed and held her revel, as soon as the fear of frost was gone; all the air was a fount of freshness, and the earth of gladness, and the laughing waters prattled of the kindness of the sun."

On this day also a snowbank which had covered a steep slope of Esquimaux Island, and into which I had plunged to my waist in ascending to the higher land on May 25th, was now breathing its last. I use this metaphor advisedly, for much of the snow must disappear by evaporation, and what melts does not all stream down the hillside, but is largely absorbed, as if in a great sponge, by the lichens and mosses. These plants fulfil here the boy's definition of a sponge as the only article with a bottom full of holes that holds water. It is not, however, fair to say that these mosses had no bottom, for, during the spring at least, they are underlaid by hard ice. For example, on 


\section{A LABRADOR SPRING}

June ist in a bog near the Natashquan River I found ice everywhere about eight inches below the surface of the moss. In a space where there was no moss, and the dark brown, almost black surface of the peaty mud attracted the sun's rays, the ice was ten inches down. On the same day in the lee of a bank a hundred feet above the sea, the sun felt hot and the thermometer registered $76^{\circ}$ when exposed directly to its rays. In the shade the temperature was $47^{\circ}$, and at a depth of eleven inches in sandy, peaty soil, all was hard frozen, and the thermometer registered $32^{\circ}$. No wonder vegetation, with such a cold region about its roots, was tardy in its appearance.

On June ith near the Romaine River back of Esquimaux Point I found the ice surface ten inches beneath the moss in the bogs where the surface was dry, while in wet places the ice was sometimes twice as far away from the surface, and in the mudholes and ponds, with the sticks at hand I could find no hard ice bottom at all. My friend remarked, in a mildly sarcastic manner, as we were resting in one of these endless Labrador bogs, that when there were no birds in sight, and I had col- 


\section{A LABRADOR SPRING}

lected all the botanical specimens within reach, and had noted down all my observations, I had always one resource left, - I could dig for ice.

My last exploration in this direction was made on the 2 ist of June. In a bog part way up the mountains above the falls of the Mingan River, I cut out a triangular piece of sphagnum with my sheaf knife, and proceeded to dissect the peaty soil below, and excavate it by hand. Our Indian guide, who could not speak a word of either English or French, gravely watched the proceedings as I gradually dug until my arm was inserted in the hole to the elbow. At this depth the ground was very cold, but I could feel no ice even with my knife-blade thrust below. I then solemnly replaced the triangular piece of sphagnum at the top of the hole, and the Indian and I silently resumed our march. I have often wondered whether he thought I was seeking for gold, was performing a religious ceremony or was merely a little crazy.

Perhaps the most notable arrival of southerners on the day of the orchid and mountain dryad, - this glorious seventh of June - was 


\section{A LABRADOR SPRING}

a kingbird we saw at Esquimaux Island. Now the kingbird is a very familiar and commonplace bird in New England, but it rarely extends its range to these boreal regions if we can judge by the fact that no one but Audubon had recorded it for southern Labrador before. But on the last day of this week, June roth, a day when my thermometer recorded the highest temperature at noon, $62^{\circ}$ in the shade, although it was but $44^{\circ}$ in morning and $48^{\circ}$ at night, a day when I found the first bakeapple flower, - the shechootai of the Indians, a burst of summer appeared in the form of delightful little flycatchers that at once took possession of all the alder thickets. The flycatcher family is a confusing one, and even the great Audubon was not infallible in this direction. For example, he says in his "Birds of America" of the wood pewee: "I have seen them in Labrador," and on June 22, I 833, at American Harbour near Natashquan he says in his journal: "I heard a wood pewee." Now the wood pewee is more southern in its range, and Audubon was ignorant of the existence of the yellow-bellied flycatcher, which was first named by Baird some ten years later, and 


\section{A LABRADOR SPRING}

which has a sweet, gentle whistling note resembling very much one of the notes of the wood pewee.

Bird songs are believed to be developments from call-notes. In some cases this is very evident. The European house sparrow repeats its nerve-racking call-note so continuously, and with such evident purpose on spring mornings, that a thoughtful observer must admit that this repetition constitutes the bird's love-song. In other birds this connection is less evident, but the evolution of the song can often be detected. The wood pewee, by the irony of scientific fate although technically classed among the nonsinging birds, has developed from its sweet and simple whistling call-note a delightfully complicated and truly musical composition, which, without question, deserves the name of a song. This in its delightful entirety is only vouchsafed in the full ecstasy of passion. A first cousin of the wood pewee, a bird that resembles it as closely as the proverbial peas resemble each other, has a very different song, which indeed as a musical performance has no claim to the name of song. This bird - the least flycatcher - is also called the chebec from the 


\section{A LABRADOR SPRING}

distinctness and frequency with which it calls this incisive dissyllable in the spring. That this constitutes the song with which it gives vent to its emotions I think there can be no question. Its call and conversational notes are simple and short. Now our friend the yellow-bellied flycatcher, whose arrival I have just chronicled, a bird that is so abundant on this southern Labrador coast after June Ioth, has two distinct notes, one a soft, musical, double whistle resembling that of its cousin the wood pewee, and a harsh incisive je-let very suggestive of the chebéc of its other cousin the least flycatcher.

I had always supposed that this latter note was its song, while the whistle was merely a call-note, but some observations I made in this Labrador spring induced me to change my mind, and tended to throw it into some confusion on the subject. Thus I occasionally stole on a bird unawares who was repeating the sweet, double whistle at frequent intervals. Here I said to myself is the first stage in the evolution of a song, which in the course of ages may become similar to the delightful musical composition of the wood pewee, when 


\section{A LABRADOR SPRING}

the bird, suddenly becoming aware of my presence, changed its note to repeated explosions of its harsh je-lét, and I was convinced of the truth of my observations, and concluded that the je-lét was merely an alarm note and not a song. Unfortunately for this theory, all the birds did not act in the same way, and the same bird varied its course at different times, for even when unaware of my undesirable presence, and in the absence of any visible annoyance, these flycatchers would sometimes repeat the je-lét in a way that suggested the pouring out of their souls in this soulless disharmony - a song not inferior to that of the least flycatcher, and that is saying a good deal. The same birds when disturbed would emit at times the double whistle note. I was forced to conclude therefore either that the yellowbellied flycatcher was developing one of two songs, one to our ears musical, the other the reverse, and, in this community at least, that the particular song had not been determined, or that the bird was developing two songs. Let us hope that the soft and liquid whistle may alone survive, and be further elaborated. I am very sure, if the bird did but know it, his 


\section{A LABRADOR SPRING}

sweetheart would prefer this song to the harsh je-lét.

A first cousin of the bake-apple, the arctic raspberry, must have blossomed about this same time, but I did not find it until June I 7 th, when I came across great masses of the pinkishpurple bloom in a marsh near the Mingan River. Like the bake-apple, this modest raspberry displays but two or three leaves besides its blossoms, and is rarely more than two or three inches high.

To return to the subject of snow and ice, I would mention a snowbank in a lovely wooded ravine near Esquimaux Point that I photographed with its leafless surroundings on June 4th. The region was almost birdless also, for although I listened for an hour at this place the only bird voice I heard was the hymn of the hermit thrush - but that one song was well worth a full chorus of bird songs. After this, hermit thrushes became common, but on this day the song was heard for the first time in this Labrador spring. On my walk to and from the snowbank I found pipits, fox and whitethroated sparrows, juncos and snow buntings, a few black-poll warblers, ruby-crowned king- 


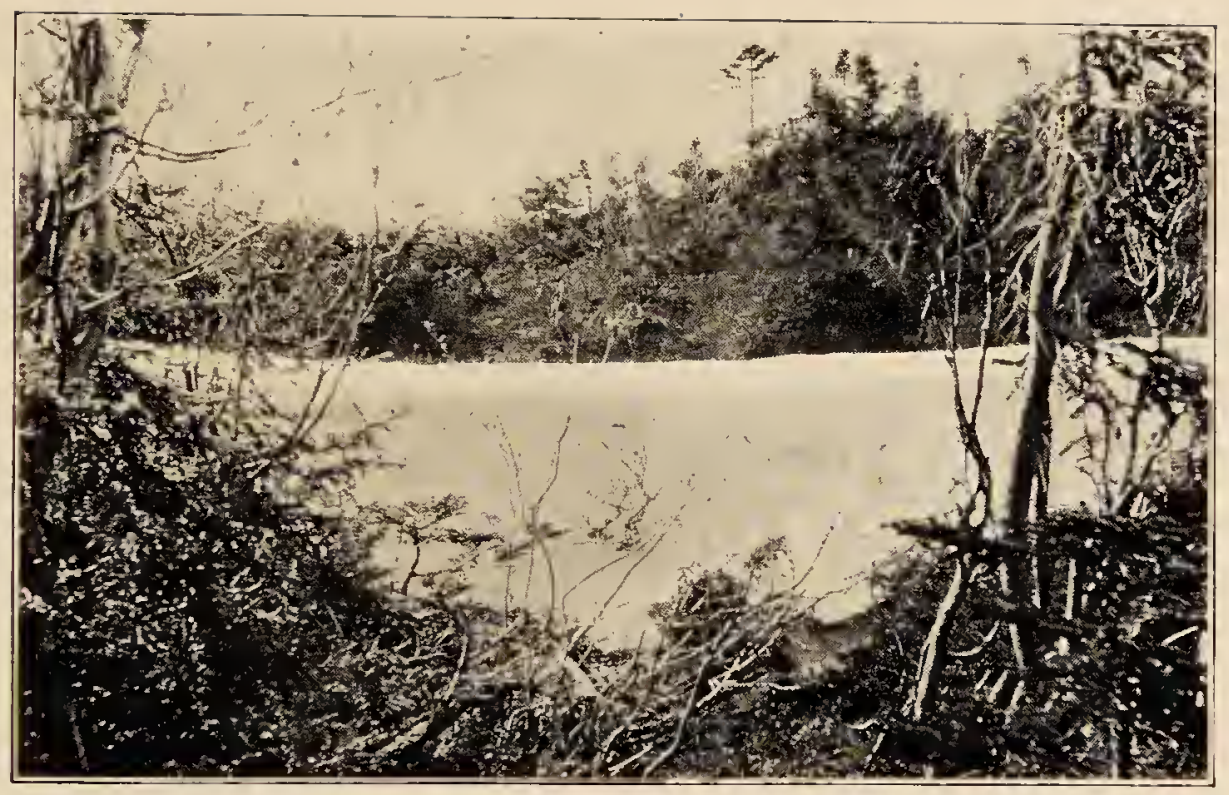

SNOWBANK AND VEGETATION JUNE 4 .

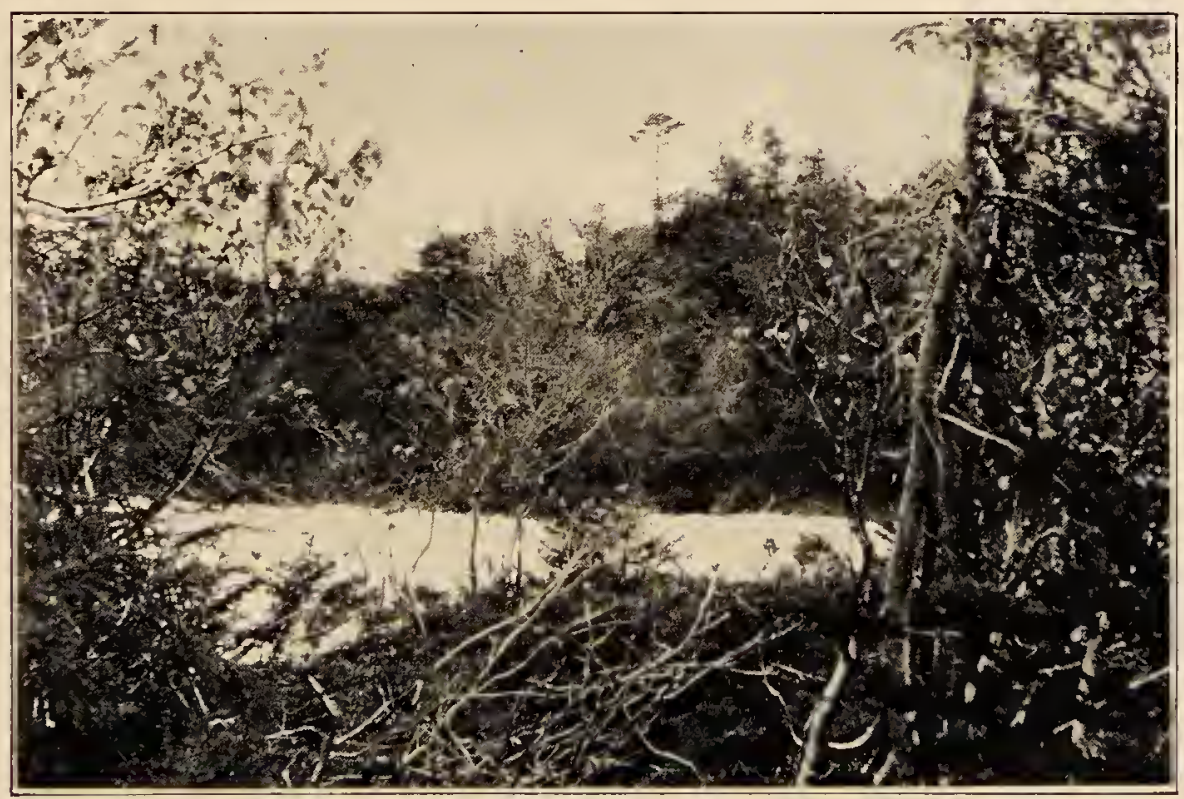

SNOWBANK AND VEGETATION JUNE 13 . 



\section{A LABRADOR SPRING}

lets and robins. On the thirteenth of June I again sought the ravine, and photographed from the same spot the much dwindled snowbank around which the alders, birches and mountain ashes were unfolding their leaves. The woods were far from silent, as they had been nine days before. Pipits and snow buntings had departed for more northern regions, but, in addition to the other birds found before, the woods were full of warblers. Blackpolls were everywhere, lisping their simple, lazy songs; brilliant magnolia warblers and redstarts displayed their yellows and reds and blacks, and sang unceasingly; Wilson's warblers, jet black in cap, elsewhere bright yellow, appeared undisturbed by my presence and sang at close range; a rare - for these parts Nashville warbler gave vent to the emotions of his heart from a clump of mountain ash sprouts, and, lastly, from among this gentle band of warblers, a Maryland yellow-throat not only sang from some bushes, but in the intensity of his passion was borne aloft to the level of the next terrace, and dove to earth again, filling the air with a confusing and surprising explosion of his calls and songs. 


\section{A LABRADOR SPRING}

In the alder thickets by the brook fed by the departing snows, yellow-bellied flycatchers were common, and the wild but tender warbling song of an unseen Lincoln's sparrow came suddenly to my ears, and, at not infrequent intervals, the more mechanical, ringing song of the winter wren burst forth. These two birds are about as easy to see as wood mice. The contrast was as great among the birds as in the appearance of the snowbank and the surrounding vegetation on these two days.

It is difficult in these days of specialism to be an all-round naturalist, but one need not be an entomologist, if one has been in Labrador in summer, to be very conscious of the fact that in this cold, brief spring mosquitoes and flies were singularly conspicuous by their absence. Although I noted two mosquitoes on June ist, and several on June $19 t h$, as well as flies, they were gentle, harmless things, and the cold kept down the ardour of their passion for human blood. In fact it was not until the last day - June 2 ist - that I was attacked by black flies and mosquitoes, and that very feebly and in scanty numbers. It is interesting to note that Cartwright on this same day of June 


\section{A LABRADOR SPRING}

in $177 \mathrm{I}$ records in his journal: "A very hot day, and the moschettos bit for the first time this year."

For this relief many thanks! I can speak with feeling, for in these parts, as old Hakluyt puts it: "There is a kind of small fly or gnat that stingeth and offendeth sorely, leaving many red spots on the face and other places where she stingeth." Hakluyt happens to be right about the sex, for the male stingeth not. In another place he speaks of "certaine stinging Gnattes, which bite so fiercely that the place where they bite shortly after swelleth and itcheth very sore." But for quaintness of description and ingenuity of spelling, the following from Whitbourne, writing early in I600 of the Newfoundland mosquito, is perhaps the most satisfactory: "Onely a very little nimble Fly (the least of all other Flies), which is called a Muskeito; those Flies seeme to have a great power and authority upon all loytering and idle people that come to the New-found-land; for they have this property that, when they find any such lying lazily, or sleeping in the Woods, they will presently bee more nimble to seize upon him 


\section{A LABRADOR SPRING}

than any Sargeant will bee to arrest a man for debt."

'The temperature of this Labrador spring as revealed by my thermometer was rather cool, for, as Whittier says:

"The Gulf, midsummer, feels the chill blockade Of icebergs stranded at its northern gate."

It averaged during the last part of May and the first part of June about $43^{\circ}$ Far., morning and night, and $50^{\circ}$ at midday in the shade. At night the thermometer generally went down to $32^{\circ}$. During the last part of our stay in June the average was $46^{\circ}$, morning and night, and $5 \mathrm{I}^{\circ}$ in the middle of the day. The highest temperature was $62^{\circ}$ at mid-day on June roth. Unfortunately, like all good explorers, I broke my thermometer on June r 7 th, so that I had no record for the last six days of our stay.

Although it was often bitterly cold in the wind and out of the sun, it was often delightfully warm when these conditions were reversed, and a complete sun-bath was surprisingly free from any sensations of chilliness, in fact " toasty warm" even in the neighbourhood of a snowbank which, by reflection, in- 


\section{A LABRADOR SPRING}

tensified the sun's rays. It is difficult to measure the exact value of the effect of the sun's rays on the bare skin, but that it is considerable is easily appreciated by. those who have tried sun-baths, and experienced the pleasant sense of well-being that results. As to the value of a plunge in icy salt water after the sun-bath, that may be open to question, and my friend remarked that I probably enjoyed these baths in the same spirit as did the historical character, who employed a boy to pinch him in order that he might experience a comfortable sense of relief when the process was over. However, in the language of the country, chacun a son gout, and my fricnd preferred to keep his clothes on, but I am inclined to think that a taste for these two invigorating procedures adds a great deal to one's appreciation of the Labrador spring, which is certainly rugged, and not one of "ethereal mildness," as the misleading quotation at the beginning of this chapter might have led the gentle reader to infer. 


\section{CHAPTER II}

FROM SEVEN ISLANDS TO ESQUIMAUX POINT

\footnotetext{
" Backward and forward, along the shore

Of lorn and desolate Labrador

And found at last her way

To the Seven Islands Bay."
}

-Whittier.

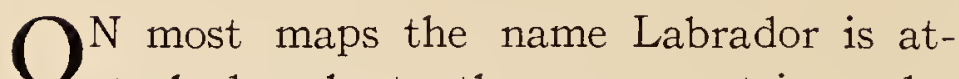
tached only to the narrow strip under the jurisdiction of Newfoundland on the Atlantic coast, yet it belongs in reality to the entire peninsula which begins at the Gulf of St. Lawrence at the point where the 5oth parallel strikes the coast. A line drawn from this point to the southern extremity of Hudson Bay, or rather of its offshoot, James Bay, separates the great peninsula from the rest of Canada. This westernmost point of the Labrador coast in the Gulf of St. Lawrence is about thirty miles to the west of Seven Islands, and about three hundred and fifty east of Quebec.

As we approached the Labrador coast, after 


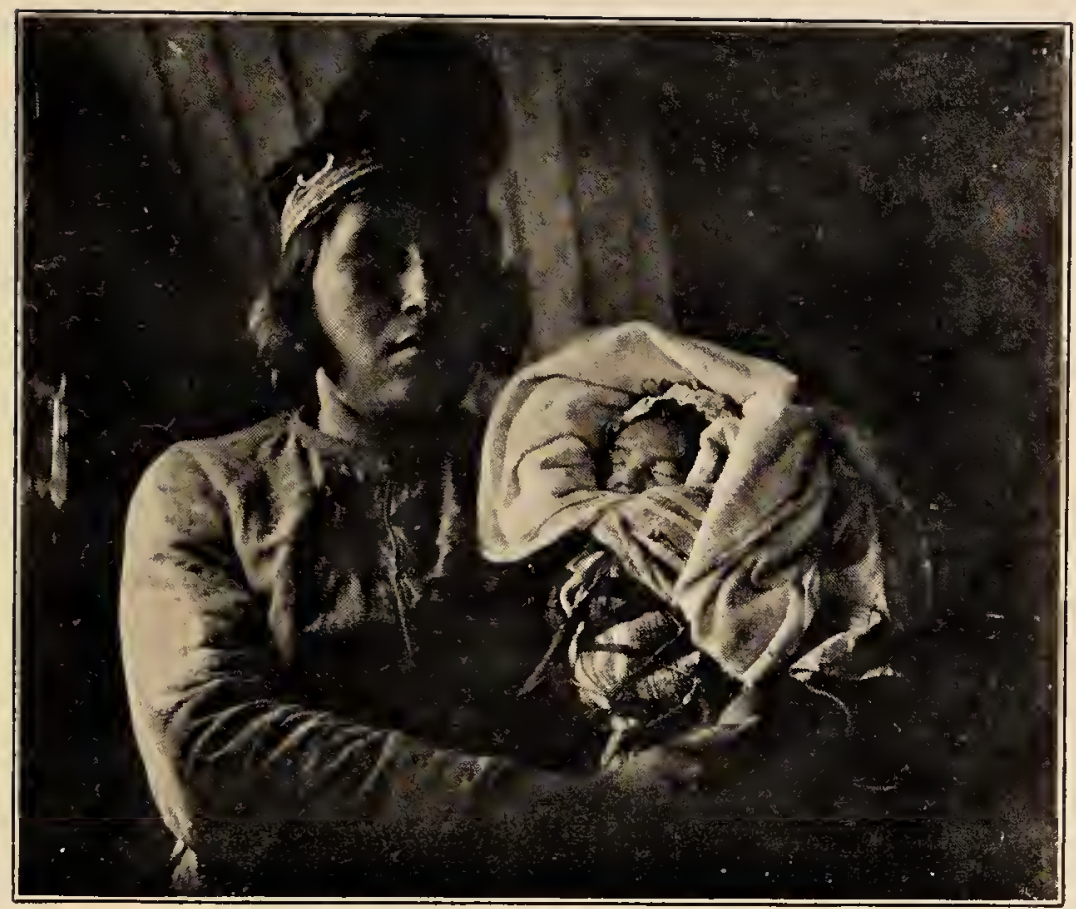

INDIAN MOTHER AND TEN DAYS' OLD INFANT.

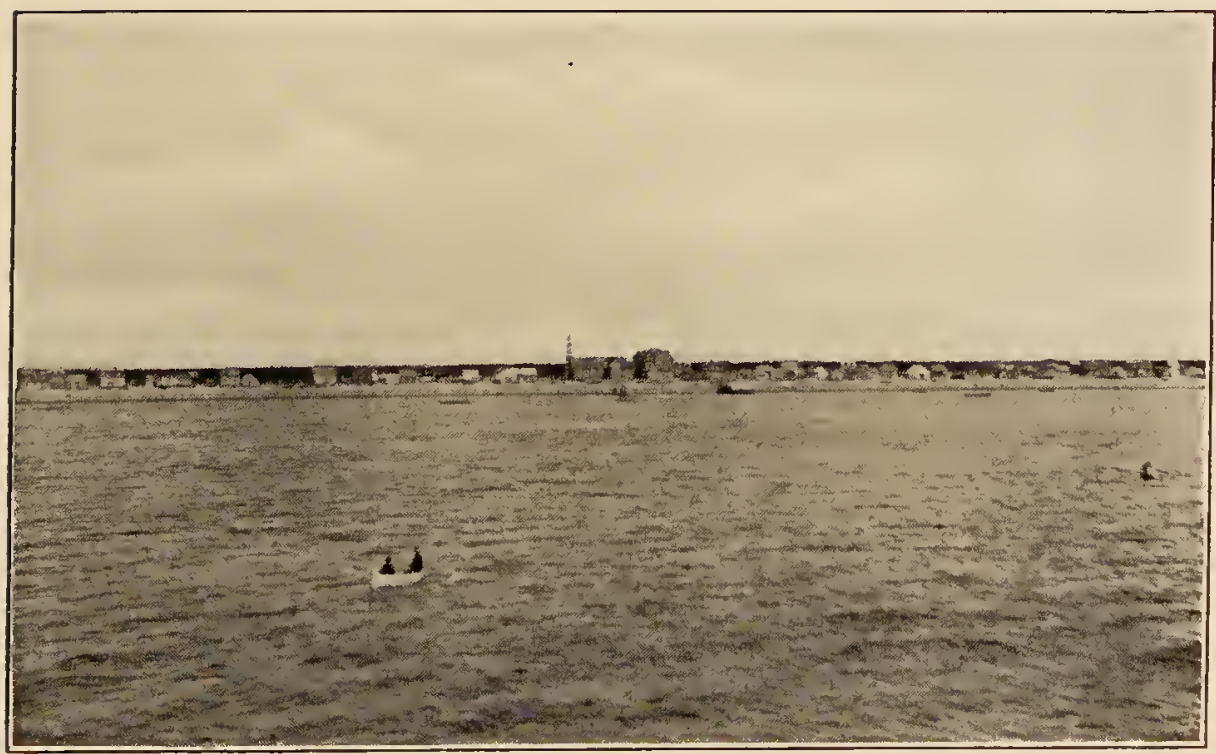

THE TOWN OF SEVEN ISLANDS. 



\section{TO ESQUIMAUX POINT}

an interesting sail down the mighty St. Lawrence from Quebec, we could see in the clear morning air the precipitous mountains of Gaspé, sixty miles to the south, in places white with snow and brilliantly illuminated by the morning sun, but dark in the shadows of the deep ravines. The whole southern coast of Labrador is notable for its rivers which empty their floods, swelled in the spring by the melting snows, into the Gulf of St. Lawrence. The first of these is the St. Marguerite River, which, like nearly all these rivers, cuts through sand bluffs and is partly blocked by a bar extending part way across the mouth from the east. The town of about a dozen houses is perched on the western bank with a setting of dark spruce forest.

The bay of Seven Islands is of great beauty and forms a nearly circular basin some four miles in diameter, and almost completely landlocked. Seven mountainous islands, of which the highest is Great Boule, block the entrance, rising abruptly from the water to a height of 500 to 700 feet, granitic, rounded, glaciersmoothed, yet well forested in places with dark spruces. The birch trees, bare and leafless 


\section{A LABRADOR SPRING}

when we steamed east along the coast, were in full leaf on our return, and dotted the dark forest with light green spots.

On the extreme left of the bay, as one faces north, under some hills which match the islands in height, was a clearing on the edge of the forest, occupied by the motley buildings of a whale factory, a familiar sight to one who has been on the eastern Labrador coast or in Newfoundland. A little further in the bay was a wharf piled with bales of white wood-pulp, which had been brought by rail from Clark City lying concealed in the forest some nine miles inland. This "city" is a model one in many ways, steam-heated and electric lighted, although its effect on the forest is not pleasant to contemplate, yet I was told that proper forestry methods were employed, so that the land was not left entirely destitute, and the continued growth of the forest was assured. From the wharf the bay sweeps around in a lovely even curve of white sand beach, backed by the eternal spruce forest, which stretches back to a mountain barrier. This bay is of interest to the ornithologist from the fact that thousands of brant rest and feed on the eel-grass there 


\section{TO ESQUIMAUX POINT}

every spring, preparatory to their flight overland of 500 miles across the broad isthmus to Hudson Bay. Their migration does not stop here, for they continue on to the far north, as they are not known to nest south of the $83 \mathrm{~d}$ degree. This migration takes place between the last week of May and the first two or three weeks of June, and as we traversed the bay going east on May $24^{\text {th }}$, and returned on June $22 \mathrm{~d}$, we missed the migration almost entirely, although we obtained from several hunters and Indian-traders a very satisfactory description of it. We did see, however, one laggard brant hurriedly flying north across the bay on June $22 \mathrm{~d}$, the last of the mighty throngs that had preceded him.

Jacques Cartier visited this beautiful bay in I539. One can imagine what his sensations must have been as he sailed day after day up this mighty gulf and river, entering as he thought the direct waterway to the mysterious East. Sir Humphrey Gilbert wrote in Hakluyt's Voyages: "Jacques Cartier . . . heard say at Hochelaga in Nova Francia how that there was a great sea at Saguinay, whereof the cnd was not knowen: which they presupposed to 


\section{A LABRADOR SPRING}

be the passage to Cataia." Beyond Cartier's farthest west lay China, and the rapids above Montreal bear the name La-Chine even to the present day.

In an ancient "Discourse of divers Voyages" it is said that "Many haue traualed to search the coast of the lande of Labrador, as well to thintente to knowe howe farre or whyther it reachethe, as also whether there bee any passage by sea throughe the same into the Sea of Sur and the Islandes of Maluca, which are under the Equinoctial line: thinkynge that the waye thyther shulde greatly bee shortened by this vyage." Sebastian Cabot had in truth " a great flame of desyre" increased in his heart "to attempt some notable thynge" when he heard that "Don Christopher Colonus, Genuese, had discovered the coastes of India, whereof was great talke in all the courte of kynge Henry the Seunth, who then reigned: in so much that all men with great admiration affirmed it to bee a thynge more diuine then humane, to sayle by the Weste into the East where spices growe, by a way that was never knowne before."

Cartier said that the Indians described some marvellous fishes that lived in the Bay of Seven 


\section{TO ESQUIMAUX POINT}

Islands, which " had the shape of horses, spending the night on land and the day in the sea." Lescarbot, writing in 1609 , says these fishes were " hippopotami." These explorers were not romancing, but doubtless referred to walruses, which in those days occurred even in this southern region.

There are many interesting names connected with the early history of Labrador. The Cabots, John and his son Sebastian, take of course first place in 1498 , and the Portuguese, Gaspar Corte-Real is a close second in ${ }^{5} 500$. In later days two names that are not usually connected with Labrador appear. Louis Jolliet, the discoverer of the Mississippi, was an explorer of the Labrador coast in the latter part of the I 7 th century, and he died there about i 700 . He married one of the daughters of Sieur Bissot de la Rivière, and became involved in the endless disputes about the seignory of Mingan. A still more unexpected name to stumble upon in Labrador annals is that of the renowned circumnavigator, Captain Cook. In I759, four years after entering the navy, he was engaged in making a chart of the St. Lawrence, and in I764 he received a commission as marine sur- 


\section{A LABRADOR SPRING}

veyor of Newfoundland and Labrador, in which "arduous service he continued until the winter of $1767 . "$

To return to our own voyage: - on the right hand or easterly extremity of the Bay of Seven Islands, in a narrow line between the white beach in front and the dark forest behind, stretches the town of the same name. The small houses all looked thrifty, brightly painted in white or gray with dark blue or red roofs, dominated by a large priests' house and a church with a tin-covered spire and a red roof. At the left hand end of the town is the Indian village with its smaller houses and church and numerous tall flagstaffs, and beyond is the Hudson's Bay Company's Post with H. B. C. in large letters on the roof of the store.

In May the larger fishing boats were still for the most part drawn up on the sand, but, as soon as the steamer came to anchor a mile or so from the shallow beach, a crowd of smaller boats and canoes raced for her. In one of the latter with an Indian was the Hudson's Bay Company's factor, Dr. Ross. The steamer was soon boarded by a picturesque and weatherbeaten crowd, and the usual excitement of the 


\section{TO ESQUIMAUX POINT}

brief exchange of mail, news and merchandise prevailed. It reminded me of similar occasions on the eastern Labrador coast, but the French language and a certain French love of dress added a peculiar charm to this more southern region. One man, who had given rather more than the usual care to his apparel, appeared in tall yellow boots and yellow riding gloves with tassels, a high starched collar and a purple necktie. His pointed waxed moustaches gave the finishing Parisian touch to the picture.

Behind the town the forest stretches to the range of low mountains which extend in a rocky wall from east to west parallel with the coast. This rocky barrier, the beginning of the high land of the interior, stretches along the entire southern coast that we visited from Seven Islands to Natashquan. In places it recedes many miles from the sea as at Natashquan, where a coastal plain of thirty or forty miles intervenes; in other places it reaches the coast, as at Magpie. At the Moisie River it is fourteen miles from the sea, and at Mingan only three miles away. At Seven Islands, although the main range is several miles back of the head of the bay, a rocky spur comes to the sea at the 


\section{A IABRADOR SPRING}

western extremity of the bay, and forms the various mountainous islands that block its mouth. Everywhere the ridge stands up as an impressive rocky barrier to the view from 600 to $\mathrm{I}, 000$ feet in height, attaining in some places, as at Mount St. John, a few hundred feet more of altitude. This mountain is entered on the charts as 1,476 feet in height. Low, the Canadian geologist, states that several of the summits in this belt are more than 2,500 feet above sea-level, and Hind found some of the mountain ranges about the Moisie River to be 3,000 feet high.

The top of the ridge, although nearly level, presents rounded gaps, through which higher mountains can be seen. To the west of the Moisie River the mountains are wooded to their summits, while to the east of this point they stand up as barren rocky ridges, clothed here and there only with patches of forest growth. During the early part of our visit, snow was plentiful in the ravines, but it grew less towards the end of June. Everywhere this ridge invited and mocked us, and we longed to reach it, and explore its rocky fastnesses. Its barren appearance like that of the rocky hills further 


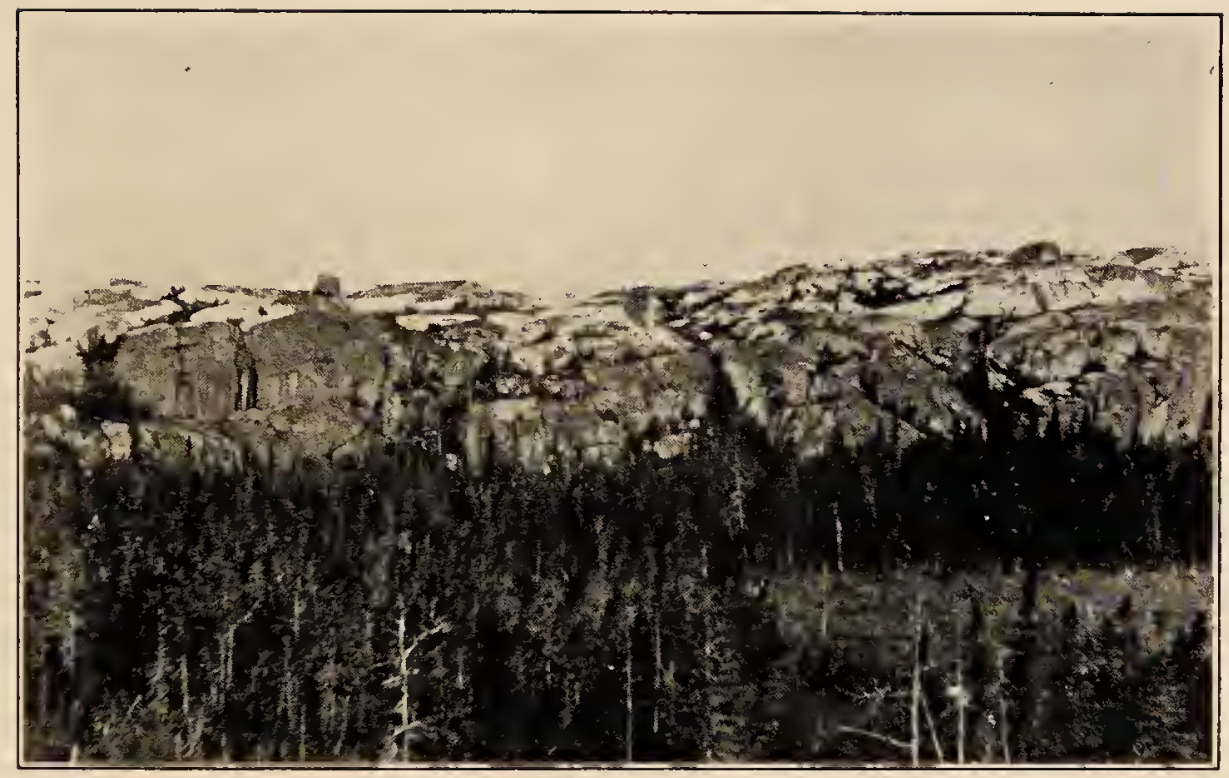

THE BARRIER MOUNTAIN RIDGE BACK OF MINGAN SHOWING POISED BOULDER.

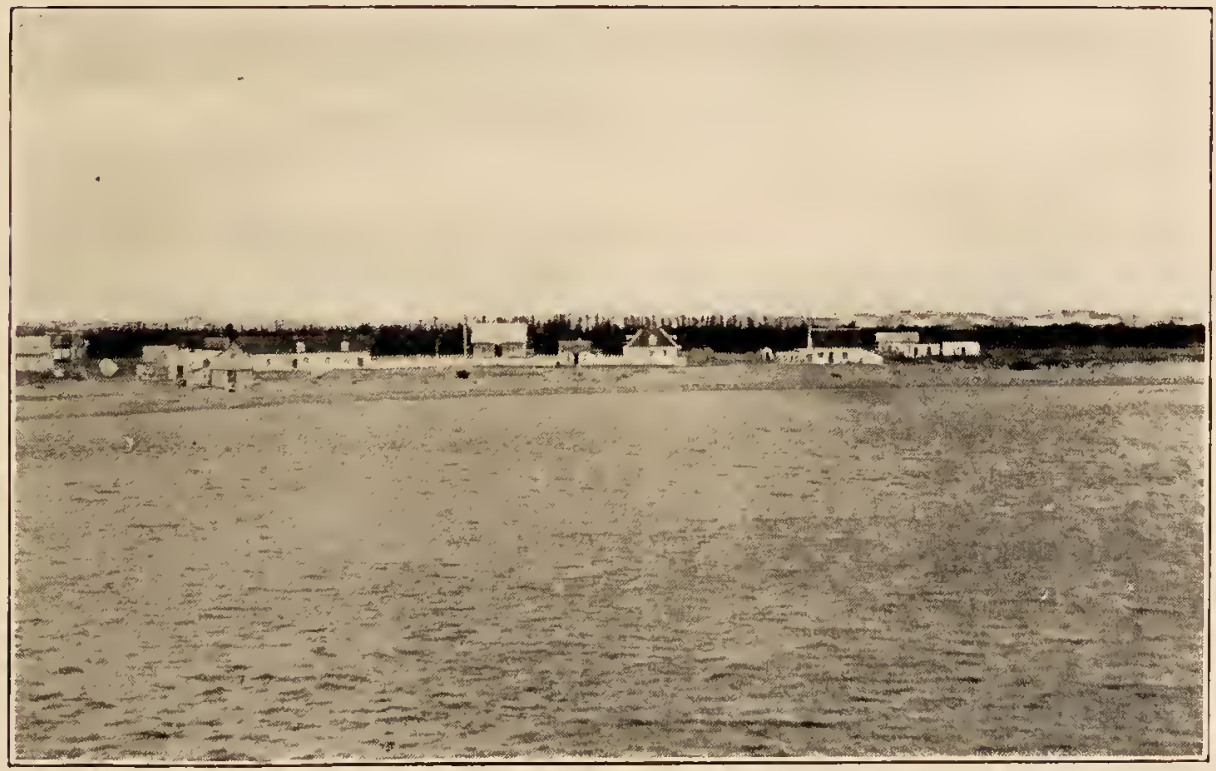

HUDSON'S BAY POST OF MINGAN. MOUNTAIN RIDGE IN THE DISTANCE. 



\section{TO ESQUIMAUX POINT}

north, and so characteristic of the eastern Labrador coast, suggested arctic conditions, and we had visions of arctic birds breeding there, of horned larks and pipits and possibly of ptarmigans. At Esquimaux Point we made our longest trip inland, a laborious tussle with the bog for five hours, yet we found ourselves apparently no nearer the mountains than at the start. According to Low the range is here twenty miles from the shore.

At Mingan, however, the approach to the high land is short and easy. A three mile paddle up the swift but smooth waters of the Mingan River brings one to the foot of the barrier, up which an Indian portage path leads to Manitou Lake, high up in the rocky wilderness. Not until the last day of our stay at Mingan were we able to take this trip, and it was well worth taking, as it solved many questions we had previously asked ourselves. The first discovery we made was that there were traces of forest growth even on the tops of the ridges, as shown by stumps and trunks of considerable size. All of these, although for the most part smoothed and bleached by long exposure to the weather, showed in their crevices and in- 


\section{A LABRADOR SPRING}

teriors the black marks of fire. The ranges beyond, still higher - for no matter how high we climbed on the elevated plateau there were always summits beyond still higher - showed also gaunt trunks, and in places a considerable growth of birch and aspen where there had probably been a previous growth of spruce.

Here was an explanation for the absence of arctic birds. The region was not arctic, although from a distance it simulated it perfectly. It had originally been clothed with a forest in which forest birds had dwelt. Mr. J. A. Wilson, the factor of the H. B. C. at Mingan, told me that a great fire had swept over this region forty years ago, starting hundreds of miles inland at the Grand or Hamilton River; it had reached the Gulf shore with a front over a hundred miles broad. Hind gives the dates of several great fires before this. Not only was the forest destroyed, but the undergrowth of bushes, the low herbs, and more important still, the mosses and lichens as well as the peaty soil were all licked up by the flames, exposing the naked framework of bed-rock and boulder. This soil destroyed represented the disintegrating work of water in its solid and liquid form, 


\section{TO ESQUIMAUX POINT}

and of vegetation working through thousands of years on the solid Laurentian rock that had been left naked and scoured by the ice of the last glacial period. The remains of this soil, the precious product of so many years, no longer protected by vegetation on the steep slopes, was soon washed down into the valleys, and these rocky hills are now almost as devoid of soil as they were when the glaciers melted. On the bare rock lichens are again growing and disintegration is gradually creeping on even there; in the crevices the mosses and the herbs and bushes are striving to gain a foothold, and slowly a soil is being formed, which after many, many years will be sufficient for the re-growth of the Hudsonian forest of spruce and balsam. Verily what a great destruction a little fire kindleth! The mills of the gods grind slowly indeed in this case!

Here at a height of five or six hundred feet glacial boulders abounded, many of them poised on slopes of such an angle that a touch seemed all that was needed to disturb their equilibrium and send them crashing into the valley below. The presence of these boulders shows that the land here had never been submerged below the 


\section{A LABRADOR SPRING}

sea since the departure of the ice-sheet from the country. Elsewhere in the lowlands between this rocky barrier and the sea, there was everywhere evidence of previous submersion, and poised glacial erratics were absent. The rocks on which these boulders lay were in some places as smooth and polished as if the glaciers had but just receded, and grooves and scratches could easily be made out.

As in the plains the hollows are being gradually filled with vegetation, and the water ousted or rather absorbed into the meshes. At a point in these mountains where I sat a narrow tarn of dark blue water lay at my feet, encroached upon from the north by the sphagnum bog. Beyond lay a bog in a broader, larger depression between the rocks, a bog still incomplete, for here and there were small circular ponds. On the other side a still larger bog was to be seen covering entirely what was originally a lake, and no spot of water remained. One must not suppose that these regions were altogether desolate. Far from it. Great patches of brilliant rhodora, varying in shade from light pink to dark crimson or purple, illuminated the hillsides. Laurels and other members of the 48 


\section{TO ESQUIMAUX POINT}

hardy heath family, dwarf cornels and bakeapple flowers were everywhere in profusion. To match these brilliant colours, a Wilson's warbler in dress of lemon yellow with a shining black cap sang from an alder thicket in the shelter of some rocks, while a full plumaged purple finch called my attention to himself by a rapturous flight song, which he repeated again and again as he fluttered upward, and made me believe I had never heard a purple finch sing so sweetly before.

While the view to the north was barred by a succession of rounded mountain tops, stretching up gradually towards the interior of the Labrador peninsula which, according to Low, varies from $\mathrm{I}, 600$ to $\mathrm{I}, 800$ feet in height, the view to the south showed the great coastal plain with its bogs and lakes and forests, its sandy shores and winding rivers, its fringe of limestone islands, forested and still bearing here and there patches of pure white snow, the sparkling blue sea, and in the distance the blue outline of Anticosti. When this coast was submerged in the distant past so that the sea washed the bases of this granite barrier and entered into the deep valleys, a shore line similar to that of the 


\section{A LABRADOR SPRING}

present eastern coast must have been formed, with its numerous outlying islands, its deep fiords or "tickles," and its land-locked harbours.

Beyond Seven Islands stretches a long beach, and, cutting through high sand and gravel banks, the dark brown waters of the Moisie River pour into the Gulf. Here the steamer anchored two miles or more from the shore, and we had a chance to study the little village of a dozen red-roofed houses and a church with our glasses during the slow process of landing salmon casks on the beach. Moisie is a great salmon station and the owners of the mail steamer, the Holliday Brothers, catch in nets great quantities of this fish every spring.

Again the beach stretched eastward, backed by an elevated gravel plain, mostly spruce covered and edged with a pure white bank of snow. The sea was like glass, and we were treated to some near views of three whales. Two crossed our bow and spouted close at hand, displaying light gray backs; another swam lazily along on our starboard side, showing a broad upper jaw and long narrow dorsal fin. Off the Saguenay we had seen numbers of white whales, 


$$
\frac{2}{8}
$$





\section{TO ESQUIMAUX POINT}

whose snowy forms contrasted well with the dark water. Once we had seen a burgomaster or glaucous gull of snowy whiteness fly above one of these, as it came to the surface, both white creatures looking perhaps for the same prey. Later in the harbour of Mingan we had watched some small whales sporting about, followed by a flock of twenty or more common terns, who screamed and darted down at the water whenever a whale appeared.

The effect of the absence of wind on the loons which dotted the surface of the water was interesting. This bird is a powerful and swift flyer when he once gets under way, but as his wings are rather small in proportion to his body, it is almost impossible for him to rise above a flat surface without the aid of the wind to oppose his aeroplanes. Out of twenty or thirty loons disturbed by the steamer that afternoon only two succeeded in rising from the water. The others attempted to rise, and struggled along with both wings and feet striking the water, going off from the steamer like meteors at tangents; and leaving wakes like boats. After a longer or shorter time, - a quarter of a minute to a minute as a rule, al- 


\section{A LABRADOR SPRING}

though one greatly terrified fellow kept up the flopping for three and three quarters minutes by the watch, - they would give up the struggle and dive, and their subaqueous departure was probably more rapid than their amphibious one. They reminded me of children who are able to walk fairly well, but, when terrified, forget their acquired art and return to a primitive scramble on all fours. Diving by loons, like walking on the hind legs by man, is an art of comparatively late development.

On this same $23 \mathrm{~d}$ of May, as we steamed east from Moisie, many flocks of old squaws or long-tailed ducks flew about us, or, rising from the water, mounted to a considerable height and flew hither and thither as if they had not yet made up their minds which way to go next. In all there must have been over a thousand of these beautiful ducks. The distance and the noise of the steamer prevented our hearing their voices, but they were doubtless as garrulous as usual, and from their talkativeness they derive their names "old squaw." On the eastern Labrador coast they are called "hounds," a very appropriate name, for at a distance, their voices sound like those of a 


\section{TO ESQUIMAUX POINT}

pack of hounds in full cry. It is an interesting and musical cry, and some of their expressions may be represented by the syllables ong-hic, and $a$-ond-a-lou. The Indians call these ducks cock-a-wee, a name doubtless suggested by some of their conversational calls. Now as we did not see any more old squaws farther east, and as there were none to be found here on our return, we concluded, - and this conclusion was confirmed by the reports of hunters along the coast, - that the old squaws like the brant migrate north over the isthmus of the Labrador Peninsula.

The sun set that night in a cloudless sky, cold, clear, golden yellow, and the glow in the northwest was very slow in fading. The twilights are long and beautiful in these regions.

Issuing from a dark ravine the Rivière Blanche pours its white cataract of waters almost directly into the sea, and in the distance in the forest the mist arising from the great falls of the Manitou River can be seen. The next stop was made by the steamer at Grand or Sandy River, a desolate rocky and sandy spot where a score of unpainted houses and a small gray church cling desperately to their mooring. 


\section{A LABRADOR SPRING}

Shelldrake and Thunder Rivers were the next ports of call, and Magpie, a picturesque little town dominated by a long building with the letters C. R. C. painted on its roof. These letters stand for Collins, Robin Company, a firm that deals in fish, as was evident from the very extensive fish-flakes that were spread out on the hillside, and that looked from a distance like a cultivated field. The town itself seemed to consist of only a dozen houses and a church built close to the rocky hill, which here comes to the sea. On our return at the end of June a fleet of twenty-six black, two-masted boats floated at their moorings, prepared to cover the fish-flakes with the harvest of the sea.

Beyond the town, the Magpie River ${ }^{\mathrm{I}}$ with its white cascade enters the sea. While we were watching from the steamer the wreath of mist that hovered about the falls, a trapper and trader with the Indians related the adventures

${ }^{1}$ I am indebted to Prof. W. F. Ganong for a hint which probably explains the existence of the unexpected name of the Magpie River. The old as well as the present name here of the gannet is margot, and this has in former days been wrongly translated magpie. Gannets formerly abounded in this region and still occur, but magpies are not found here. 


\section{TO ESQUIMAUX POINT}

of a certain famous ox and of a traveller by this same cascade. He told the story briefly in English, but noticing the interested and puzzled looks of our friend the good priest of Esquimaux Point, he retold it in French, enlarging skilfully on the details, and embellishing the whole with gestures and facial expressions that added much to the realism of the account in a way that only a French version could give.

It seemed that a certain ox of the village of Magpie was in the habit of wandering along the little road that leads to the river for the sake of the good pasturage there, and, being of a social disposition, and having no friends of his own race with whom to associate, for it was the only ox that the village boasted, and much petted and familiarly conversed with, - he was wont to welcome all human beings passing along the road. If they stopped, he would nose up against them in the most friendly manner; if they walked, he would sedately walk beside them; if they ran, indeed he would run too, and he could run well, very well for a great ox, but then he was very fond of human companionship, and that accounted for it all, and indeed all the villagers understood 


\section{A LABRADOR SPRING}

and appreciated him. Now one day there passed along this road a stranger on the march for the Hudson's Bay Post of Mingan, an elderly man of timid disposition, and ignorant of the customs of the Magpie ox, and indeed not familiar with any horned cattle.

As he approached the bridge that crosses the river near the cascade, he perceived the ox grazing by the roadside, and quickened his pace, for he did not relish such close proximity to a great beast with long horns, and these with such sharp points. Our friend the ox stops grazing and steps out rather quickly in order to say bon jour, so to speak, to the traveller. He, poor man, starts to run to escape what he believes to be an animal with vicious intentions, and to his terror the beast runs after him. Away they go, faster and faster, down the hill towards the bridge. Just before reaching this point, the road turns sharply to the left at the river's brink. The man, terrified as he is, has enough wits left to take the turn successfully, and gains the bridge, but the ox in the ardour of his desire for social intercourse, and the slowness of his mind and of his huge bulk, is unable to turn quickly 56 


\section{TO ESQUIMAUX POINT}

enough, but crashes through the single rail over the bank - down - down - down like a plongeur into the Magpie River.

The good man relieved of the pursuit of this ravenous beast, but trembling like a leaf in every limb, tells his beads and gives thanks to the bon Dieu. Across the bridge he goes, but he is suddenly struck stiff with horror at the reappearance of the ox, who, having arisen from his plunge, like a veritable plongeur that he is, has swum the river and clambered out on the rocks of the opposite shore.

At this point in the story the trader, like a good raconteur, suddenly ceased his tale with arms wide spread and an expression of horror in his face. None of us asked what happened next, but he confidentially assured me on the following day that the story was entirely and exactly true.

The St. John River, about a hundred miles from Seven Islands, is the next stopping point, and, while we anchored, boats with red sails came out to greet us. The town is built on the lowest of three sandy terraces on the right bank of the great river, which is blocked at the mouth by a sand-bar extending half way 


\section{A LABRADOR SPRING}

across from the east, behind which are sheltered the fishing boats. Back of the little village with its faded pink church was a great cross on the bleak hillside, and in the distance, about a dozen miles from the sea, Mount St. John, looking as if it had split open and fallen apart, stood up blue and snow flecked.

Again more beach and Long Point was reached, a flat sandy place, a not inconsiderable village abounding in fishing boats, but destitute of a harbour. Some of the houses were of logs, others clapboarded and neatly painted peagreen, yellow or slate with red roofs. There were two churches, a large new one evidently to replace the old one. Behind stretched the eternal forest of pointed firs and spruces, and the grim barrier of rock, blue, gray and white, brought up the rear. Men pushed out through the surf to meet the steamer, while boys and mongrel dogs waited on the beach. About six miles off Long Point on one of the Perroquet islands is a lighthouse.

The Perroquets were formerly the nestingplaces of countless puffins, razor-billed auks and gannets. Now these birds are all gone except a few pairs of puffins and possibly a razor- 


\section{TO ESQUIMAUX POINT}

billed auk or two. Lucas, who visited the islands in $\mathrm{I} 887$, found "a few Gannets - in spite of the incessant persecution of the Indians who regularly make a clean sweep there." The persecution continued and no gannets have nested there for fifteen years. The birds have a sentimental attachment for the spot, however, and visit it every year, and on June 2 Ist we saw about thirty of these splendid birds flying near the island.

Of an entirely different character from the forlorn little villages we had passed was the trig settlement of Mingan, some six miles beyond Long Point, protected from the sea by a wooded island which shelters a deep sound. The dominating feature here was the Hudson's Bay Company's Post neatly fenced and painted as all these posts are. This was flanked on the west by the Indian village, and on the east by the substantial house of a salmon fisherman, where we made our home during the latter part of June for a week.

While the Seven Islands are granitic, and rise steeply to rounded summits, the group of Mingan Islands which begins off Long Point at the Perroquets and extends for fifty miles to St. 


\section{A LABRADOR SPRING}

Genevieve Island are flat-topped and composed of light gray limestone, whose strata are nearly horizontal but dip slightly to the west and south. These islands vary in size from those of an acre or two in extent like the Perroquets, which rise but a few feet above the water, to those of ten or fifteen miles in circumference, like Esquimaux Island, with cliffs seventy-five or one hundred feet high.

All display the effect of the wear of the ocean on the limestone cliffs, which are often hollowed and turreted in a curious manner. In places great caverns are formed by the waves; in others rounded pillars are the predominant features, and, owing to the varied resistance of the strata, these pillars sometimes assume strange shapes. If the harder layers are in the middle, the pillars become worn above and below, and a series of spinning-top shaped masses line the shore. In other places, where the denser layers are on top, the wear results in toadstool forms which sometimes extend for considerable distances along the water front. In many ways these limestones reminded me of the water-worn ice formation seen on the eastern Labrador coast. 


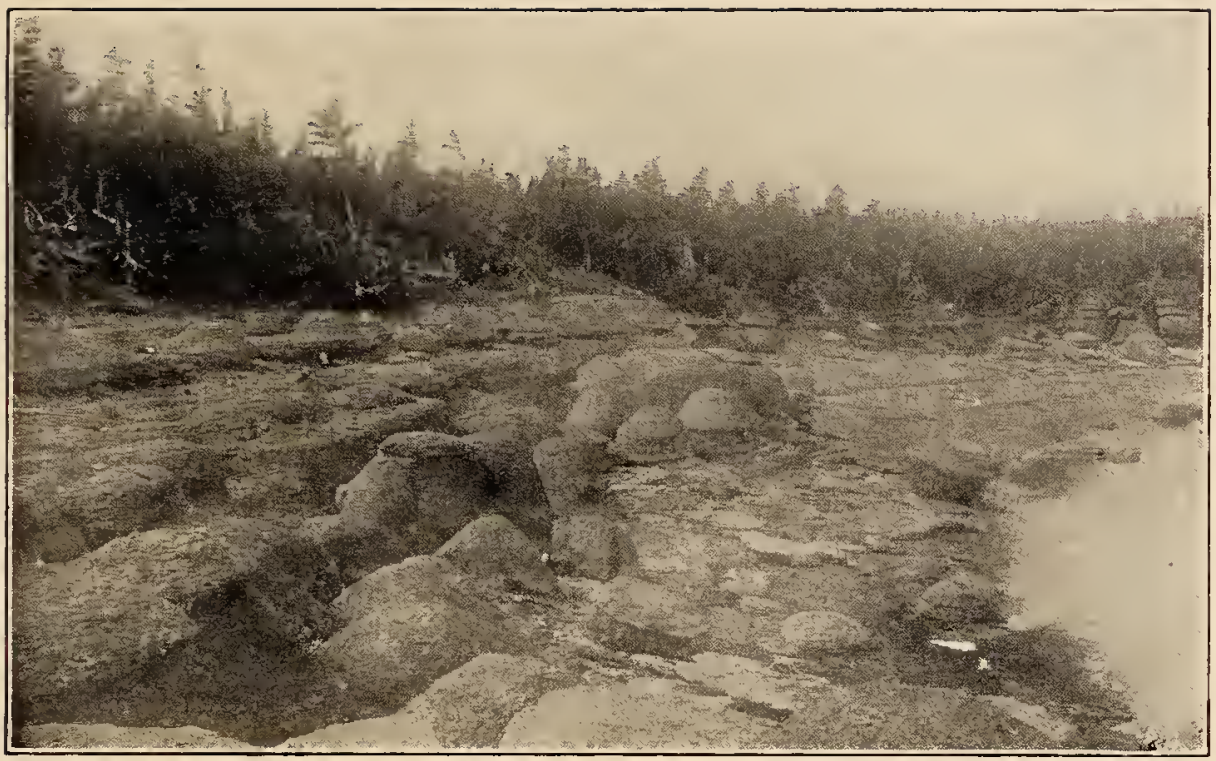

TOADSTOOL-SHAPED LIMESTONE ROCKS AT ESQUIMAUX ISLE.

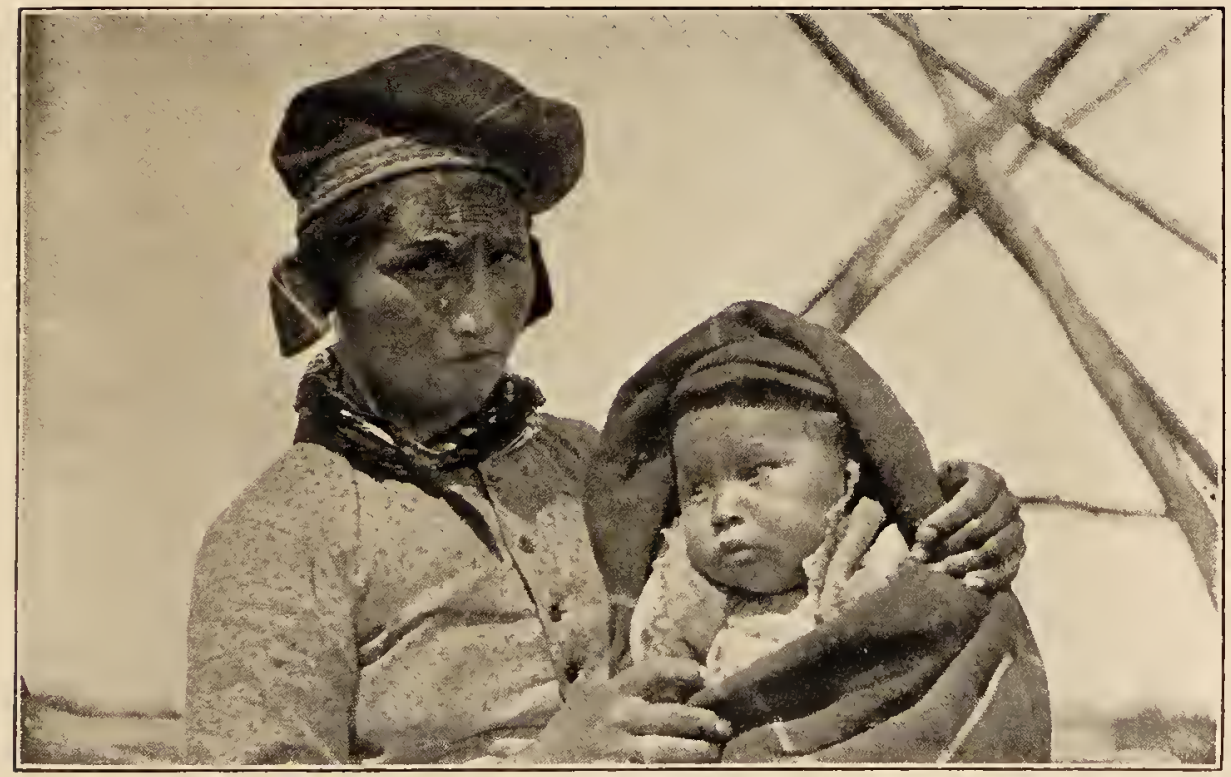

INDIAN MOTHER AND CHILD AT MINGAN. 



\section{TO ESQUIMAUX POINT}

In other places the immediate shore is a flat shelf of limestone, smoothed, polished and grooved by the glaciers of long ago. Many of these grooves are shallow, rounded depressions several yards wide, extending south into the sea, and slightly sloping in that direction. So smooth and uniform are these shelves, that they would make perfect slips for whale factories; all that is needed is a tackle on the land, a whale in the water, and the thing is complete. In some places, however, this fresh polished surface is marred by numerous little hollows which suggest selective solvent power of water on some of the ingredients of the stone. In other places the limestone is cracked and broken off in square blocks suitable for house building, or in smaller fragments making pebbly beaches.

As the islands are all alike in a way, a description of Esquimaux Island, which we frequently visited from the village of Esquimaux Point, will do for all. This island is separated by a sound three quarters of a mile wide from Esquimaux Point, and is of irregular outline with numerous deep bays. On June 3 d we had a splendid opportunity to study the limestone formations of the island, for we walked around 


\section{A LABRADOR SPRING}

its entire coast line, and concluded that although the island was only about three miles in diameter, its periphery with all the sinuosities measured at least fifteen miles. My friend believes the distance is much greater, and as we walked without stopping the last four hours, after we had already gone a considerable part of the way, I am inclined to think he is right. Granite rocks are soft in comparison with these hard, marble-like limestones, and the effect on my hob-nailed shoes was disastrous. It was hard walking, and I was reminded of the saying, "Hit hisn't the 'unting that 'urts the 'oss, hit's the 'ammer, 'ammer, 'ammer on the 'ard 'igh way."

The cliffs on the eastern end of the island are particularly fine, and in one of the inaccessible hollows an ancient nest of a raven was to be seen, made up of a multitude of weatherworn sticks piled up and woven together to a mass the size of a clothes basket. Although the ravens were said to breed there every year, we saw no signs of them on our visits. It was evident, however, that a few black guillemots or sea pigeons were nesting in the deep crevices of these cliffs, for they often flew out on our 


\section{TO ESQUIMAUX POINT}

approach and swam nervously about in the water outside. Everywhere the water was dotted with eider ducks.

The centre of the island consists of tangled forests and sphagnum bogs, and differs in no ways from the character of the mainland. On the borders of the bog-pools, eiders and great black-backed gulls were generally resting, their striking black and white plumage contrasting well with the vegetation. One could easily spend a whole summer on this one island, and not discover all its secrets. 


\title{
CHAPTER III
}

\author{
AN ACADIAN VILLAGE \\ "Where a few villagers on bended knees \\ Find solace which a busy world disdains." \\ - Wordsworth.
}

IN the year 1605 a small party of Frenchmen with their wives and children came from the western part of France, from Rochelle, Santonge and Poiteau, to establish homes for themselves in the new world. They settled in what is now known as Nova Scotia, but which came to be known in those days as Acadia, and the French settlers, who thrived and spread to New Brunswick, Cape Breton, Prince Edward Island and the Magdalens, as Acadians. Because these people are generally pictured as a happy, pastoral race, one is apt to suppose that the name Acadia is a corruption of Arcadia, but this is not the case, for it is derived from a word-ending of the Micmac Indian language, meaning " the place of " or " region of," and was used as a suffix by these Indians in 


\section{AN ACADIAN VILLAGE}

numerous names of places. The name has also been derived from the Indian Aquoddie, meaning the fish called a pollock.

The deportation of the Acadians from Nova Scotia in 1755 is well known, and is familiar to all from Longfellow's poem of Evangeline. About a hundred years later, namely in 1857 , Ferman Boudrot, an Acadian from the Magdalen Islands, sought to establish a home at Esquimaux Point on the southern Labrador coast, and his example was so contagious that in I86I, when Hind visited the place, there were already forty Acadian families settled there. Now there is a little village of some one hundred and twenty houses, a substantial church with a steeple and a priests' house.

That La Pointe aux Esquima uxde La Côte $d u$ Nord is peopled by those of French descent is obvious, for, as Thomas Hood used to say, even the little children speak French - such as it is - a patois which always suggested to me that the language of Paris had been chewed and partially swallowed. However, if my knowledge of the French language had been greater, I should doubtless have recognized traces of the ancient dialects of the parts of France from 


\section{A LABRADOR SPRING}

which the Acadians came, and the French language of the sixteenth century. The little children shrugged their shoulders delightfully, and said s'paw as cleverly as their elders. Now $s^{\prime}$ paw is merely a contraction of je ne sais pas, and corresponds to "I dunno," or to the more forcible "search me" used by our friend the Yankee painter. Only the doctor and the storekeeper as far as I could discover spoke English in this place.

The continued use of the French tongue by a people living under the English flag, extending through so many generations, is interesting and is found not only in out of the way places like this little village, but also in a city of the size of Quebec, where one sees the words " maison a loué" placed above " house to let." The French and English appear as difficult to mix as oil and water. That a certain amount of assimilation, however, has taken place is shown in the use of the word potates instead of pomme de terre, and in the incorporation of various terms used in connection with navigation. For example, "heave tranquilement" and "heave le slack away," and "go ahead un peu" were orders which arrested my attention on the 


\section{AN ACADIAN VILLAGE}

French steamer that plied along the coast. The sign "Passagers are not admit on Footbridge" showed a recognition of the existence of English-speaking people, and a desire to reconcile the two languages.

As the people of Esquimaux Point are all fisher-folk, their houses are strung along the shore so as to be in close touch with the pastures of the sea from which the harvest is gathered. Each family lived in a picturesque little house, and, as they all were very similar in appearance, one description will do for all. They were of wood neatly painted in white or gray with dark coloured roofs, their greatest charm, aside from the little dormer windows, being the graceful up-curve at the eaves, a universal characteristic. The windows all in one piece appeared to be permanently sealed, but as June advanced the winter fastenings of some were withdrawn, and they were opened to the air. Plaster was not used in the construction of these houses - indeed only two plastered houses did we find along this Labrador coast - but the generous wood-piles and the stoves made to burn half a dozen long logs at once gave an idea of the warmth to be 


\section{A LABRADOR SPRING}

found in these thin-walled houses even in mid-winter.

The firmly closed windows of these houses reminded me of a former experience on the eastern Labrador coast. My companion and I occupied an 8 by io room, and, being peculiar, felt it essential to have the window open. This was not easily accomplished for the window, either through lack of practice or because it was not intended to be opened, was almost as immovable as the rocks on which the house was built. However, we at last managed to raise it far enough to insert our arms in the crack, and then, with a heave all together, we succeeded in wedging it up about eighteen inches, enough to let the fresh air blow in and the fog. When we left, my friend remarked that they would have some difficulty in closing that window, and as we stopped at the same house on our return from the north, I was amused to see that his prophecy was correct, for there were marks of blows on the window-frame and an axe was in the corner. The axe stood us in good stead in opening the window again. Dr. Grenfell's hardest work is to teach the Labradorians the value of fresh air inside their 


\section{AN ACADIAN VILLAGE}

houses. It is said that Newfoundland owes the purity of its air to the fact that the inhabitants keep their doors and windows tightly closed, and it seems probable that Labrador owes its wonderful atmosphere to the same cause.

The church with its steeple and the priests' house were of ample proportions, well painted and prosperous looking, and timber was being hauled for a new convent to replace the one recently burned. In the convent the youth of the region is instructed by the good sisters. Several large crosses were placed at various points in the village and a crucifix was in the little burial ground. From the eastern extremity of the town to the church, a distance of over a mile, a long, narrow, well fenced lane stretched parallel with the beach, and in this lane a few cattle always wandered. One of these was familiarly known to my friend and myself as "Paul Potter's bull" from his resemblance to that celebrated animal, but his familiarity with the human race at close quarters had rendered his disposition so amiable that we soon lost our instinctive fear of him. The object of the high fences on either side of the 


\section{A LABRADOR SPRING}

narrow lane, fences sometimes consisting of seven or eight bars, was to keep the cattle from the little garden plots of which each house boasted.

The first of June appeared to be the beginning of the spring season with the agriculturalists of Esquimaux Point, for at this date the tilling of the gardens began. With the aid of broad bladed mattocks, deep furrows were made in the dark peaty and sandy soil, the women working side by side with the men, if haply these latter were not engaged with their boats, and the familiar pictures of French peasantry were at once suggested. The soil is enriched with dark, strong-smelling seaweed brought by boats from the islands, and the seeds planted; turnips and cabbages, salads, radishes and potatoes were the chief crops. The rhubarb was just beginning at this date to peep above the ground.

Near the houses large black pots were often hung for the purpose of washing clothes, and a few open air ovens were to be seen, although the modern stoves had almost entirely crowded out these picturesque relics of the past.

The fourth of June seemed to be an es- 


\section{AN ACADIAN VILLAGE}

pecially busy day in this community; agricultural operations in the little house plots were in full progress, and the farmers were generally of the female gender, although boys as well as girls assisted their mothers, who, in short, woollen skirts, with bright handkerchiefs about their necks or on their heads, were labouring with mattocks to complete the work. The men were busy painting their houses or boats, which, drawn up on the beach out of the reach of the storms, had weathered the long winter under thatches of balsam boughs. New rigging was being installed, new spars were trimmed, nets and sails were spread out to mend, and the whole place showed an air of great bustle and activity. From time to time the men would leave their own work to gather in numbers to assist a neighbour to launch his boat.

One very enterprising man had already been out to fish, and had brought back the first cod of the season, his small boat half filled with them. A group of men surrounded the boat on the beach to talk ovcr the exciting event after the long winter. It was all good fun. Our friend the Yankee, - and Yankees 


\section{A LABRADOR SPRING}

are not slow in talking, - said he never saw people with so much to say to each other. If they meet after two hours' absence, he said, they jabber away as if they had not seen each other for months. For example, he had watched six men shingling the roof of the doctor's house, and they were talking so hard that only semioccasionally was a nail driven. A couple of Yankees, he was sure, could have done the work in half the time - but this perhaps was merely spread-eagleism.

At all events, the people seemed to be enjoying themselves and to be looking forward with pleasure to the short three or four months' fishing season after the long winter. The winter is the season of wood-cutting, of risiting and of travelling along the icy pathway of the coast on dog-sleds, while the summer is devoted to fishing, and about I 50 sails hail from Esquimaux Point. The summer is their season of work, the winter they call play.

The boats, like the houses, are all of the same type. Each boat was about thirty feet in length, pointed at both ends and schoonerrigged with two masts, although the jib and a bowsprit were often lacking. Picturesque 


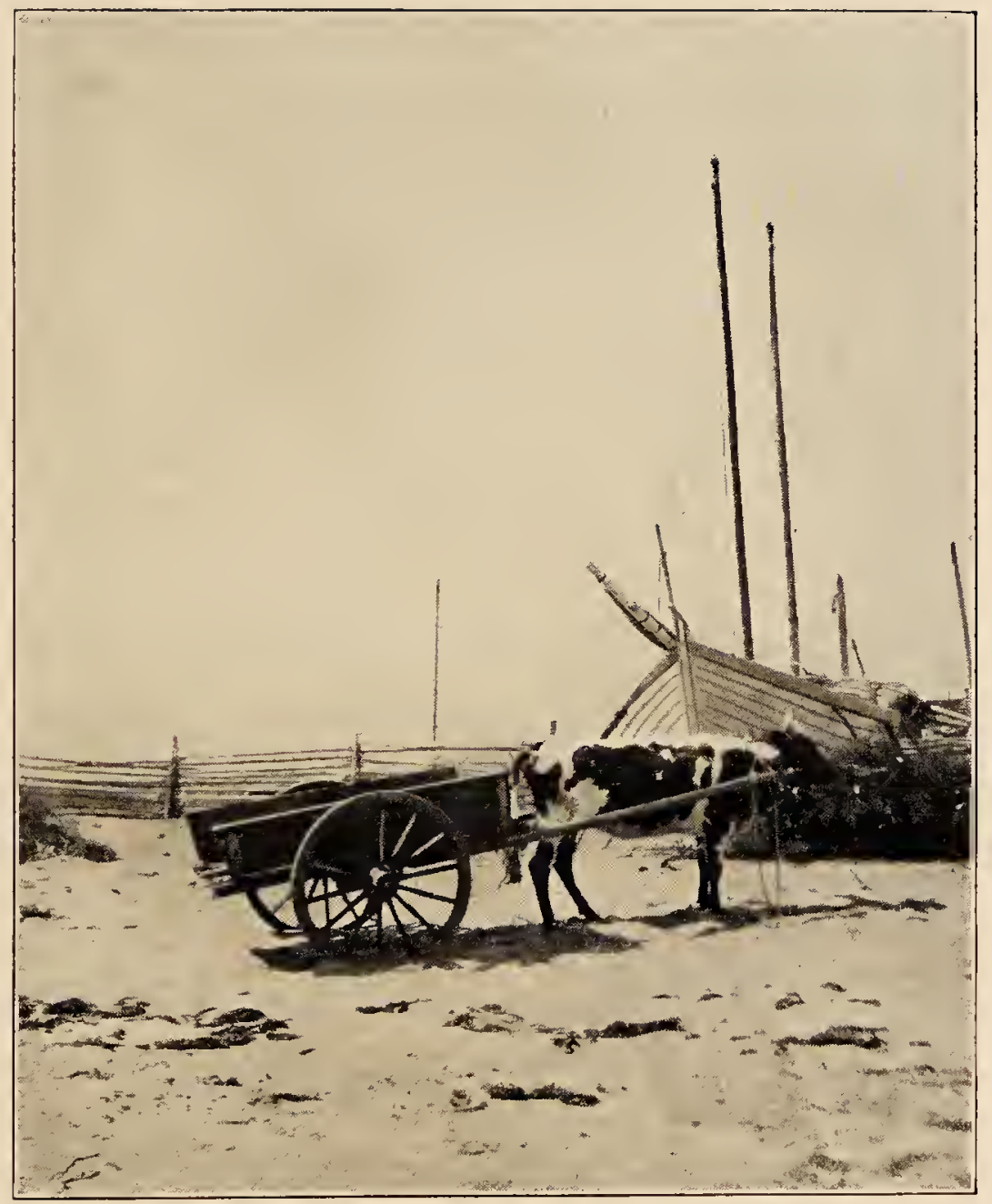

PREPARATIONS FOR THE FISHING SEASON. 



\section{AN ACADIAN VILLAGE}

boats they were, especially when the sails were dyed a light pink or terra cotta red to preserve them from the weather. About the middle of June they all depart for the cod fishing banks off Natashquan, and they return with their cargoes of dried and salted fish about the middle of July, to begin the deep-sea fishing eight or ten miles off the home port, a season that lasts two or three months more. Hand lines only are used, which leave their impress in deep grooves on the sides of the boats. Net traps, so universal on the eastern coast of Labrador, are not allowed here.

The scene in the village and on the beach at this time was always interesting and picturesque. One man in the hurry of his work had pressed a small cow into service; she was dragging a tiny cart loaded with ropes and nets down to his boat on the beach, while he dramatically strode on ahead.

Religion takes a prominent place in the lives of these people. The church bells ring out many times a day to summon them to prayer, and to prayer they go, not the women and children merely as in some communities and some faiths, but men too unless they are absent 


\section{A LABRADOR SPRING}

at their duties. These bells, which were " jangled, out of tune and harsh," so interfered at times with my observation of small birds, whose notes I was trying to detect, that I was often tempted to say "Silence that dreadful bell: it frights the isle from her propriety."

As the village is a village of fishermen, it is appropriate that St. Peter should be its patron saint, and that a large tin fish perforated with the name of St. Pierre should swim as a weathervane on a mast in the church yard, and that St. Peter's cock, very fat and of considerable height, should act as a vane on a large cross at the end of the town. Still more appropriate is the painting over the altar in the church of the miraculous draught of fishes, where the boats are such as might be used at the present day on this stormy coast, and the details of pointed sterns and thole-pins have a familiar look. The painting, a copy of one by Tissot, is the work of a self-taught native, and is remarkably well done in soft and harmonious colours. Doubtless many a sturdy worshipper, while his lips moved in prayer as he counted his beads, has cnvied the success of this draught, 


\section{AN ACADIAN VILLAGE}

and has instinctively calculated its weight and value, for one can easily count the fishes, they are very accurately done and are not painted in the impressionist style. I was very glad that it rained hard one Sunday morning, so that I should not be tempted afield, and I went to church for the principal service. As the bells jangled from the steeple, mine host led me up the front steps which were crowded with men, who politely touched their hats and made way for us as we entered the church. Up the main aisle I meekly followed my guide, feeling the penetrating gaze of all the congregation fixed upon me. With a flourish I was given the front pew and left to my meditations. The vacant places in the pews must have been soon filled, I imagined, as I did not at first dare to look back of me, for I could hear the stamping of heavy boots as the crowd of men filed into the church at the last moment. When I did summon up courage to look around, I was impressed with the black clothes of the worshippers, - the brilliant sweaters, dresses and handkerchiefs of the workaday life had vanished, to be replaced in the women by black caps and black dresses, and in the men by coats, 


\section{A LABRADOR SPRING}

which, although often weather-beaten to a lighter hue, were evidently intended to be black. In the gallery near at hand was a row of a dozen little girls, among them my friends Lalouise and Yvonne, each with her black eyes uninterruptedly fixed on the strangers in the front pew. As I cast surreptitious glances about the church from time to time, I could not help noticing the similarity in type between these sturdy Acadians and the peasantry of France with whose forms and faces modern French art has made us so familiar.

The service seemed to be very sincere and impressive, and the ten little boys, the acolytes, whose brown faces and hands, and whose shocks of brown hair contrasted well with their white vestments, each did his part well. The sermon was on La signe de la croix, which the good father showed was everywhere, for even the birds in the air as they fly, and the fishes in the sea as they swim, make the sign of the cross. I believe I shall always remember these words which rang out through the church at the end of almost every sentence. I could not help thinking as I watched the two priests with their strong faces, their black robes and 


\section{AN ACADIAN VILLAGE}

their brilliant vestments, of les robes noirs, who accompanied the explorers of the seventeenth century in these parts, and of the admiration and astonishment they caused among the savages, for whose conversion from paganism they laboured so hard. Then the power behind them was a mighty power in the kingdom of France. Now they are outcasts, repudiated in their own home, the French Republic, and are seeking liberty to practise their religion here in the new world.

Of the present bishop of this region, Monseigneur Gustave Blanche, it is said in a pamphlet describing his inauguration to office in $\mathrm{r} 905$ that "the violent persecution of I 903 found him at his post. Thrown on the street, like all the clergy that an impious government could no longer endure, he took, with a hundred of his brethren, the road to Canada in the month of August, I 903. " r These were the Eudiste fathers, a branch founded by Jean Eudes. Up to 1867 all the territory of Labrador was part of the

${ }^{1}$ Translation from "Les Fêtes du sacre de Mgr. Gustave Blanche, evêque titulaire de Sicca, Vicarre, apostolique du Golf St.-Laurent. Célébres á Chicoutimi les 28 et 29 Octobre, I905." Quebec, 1906. 


\section{A LABRADOR SPRING}

diocese of Quebec, but after Rimouski was erected into an Episcopal seat, all that immense country of the north-east was detached from Quebec and included in the new diocese, which was called "La Prefecture apostolique du Gulf St.-Laurent." This includes the northern shore of the Gulf of St. Lawrence from Portneuf to Blanc-Sablon, and extends to the north and east as far as Hudson and Ungava Bay; it also includes the island of Anticosti. Previous to 1903 it was difficult to find priests for these isolated regions, but the difficulties were, as the pamphlet says, removed by the "providential banishment" of the Eudiste fathers from France in that year and their assumption of the work in this diocese.

The fathers certainly have most devoted followers in this little village of Esquimaux Point, and their piety was beautifully shown at the celebration of the feast of Corpus Christi, which occurred on the last Sunday of our stay at the place. The village was gaily decorated. Long strings of bright flags and pennants stretched from the church, and a long lane down one side of the village brook, across a bridge up the other side, and so on across another bridge 


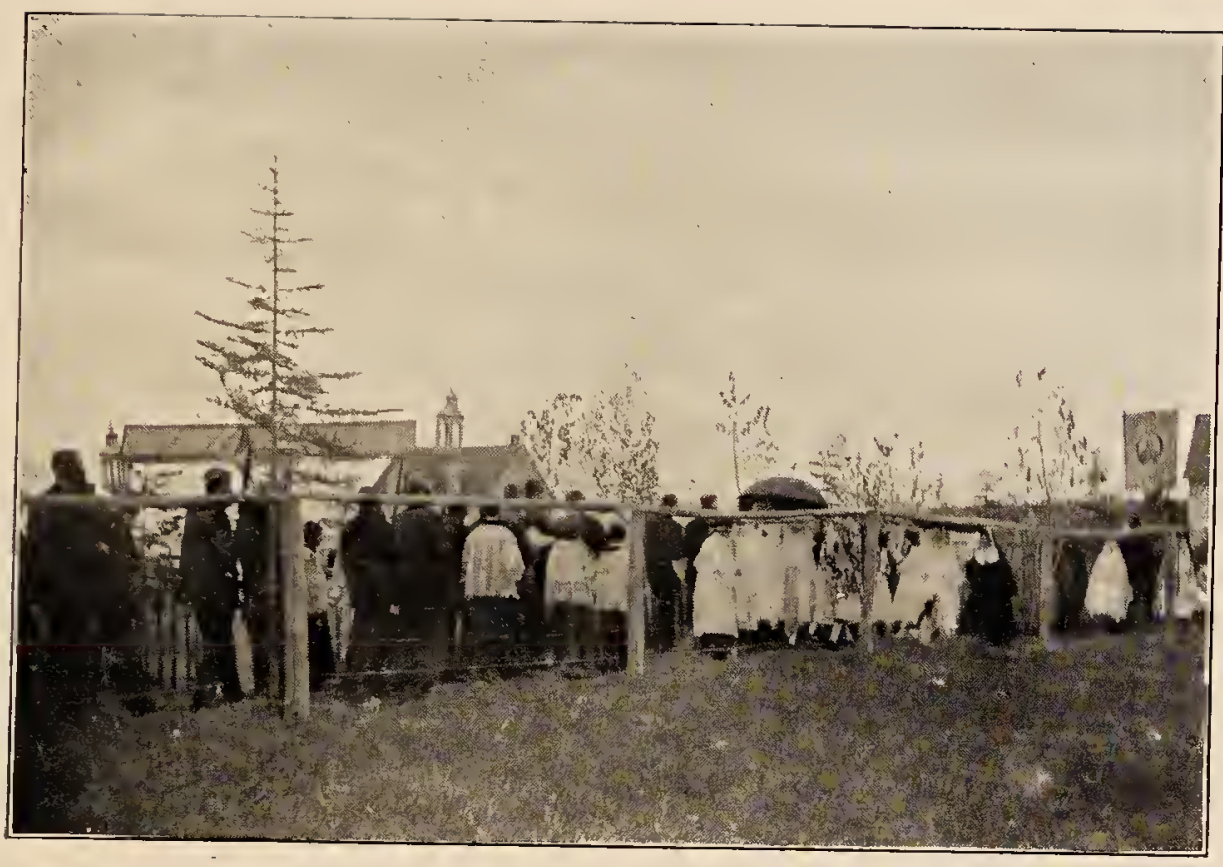

THE PROCESSION AT THE FEAST OF CORPUS CHRISTI AT ESQUIMAUX POINT.

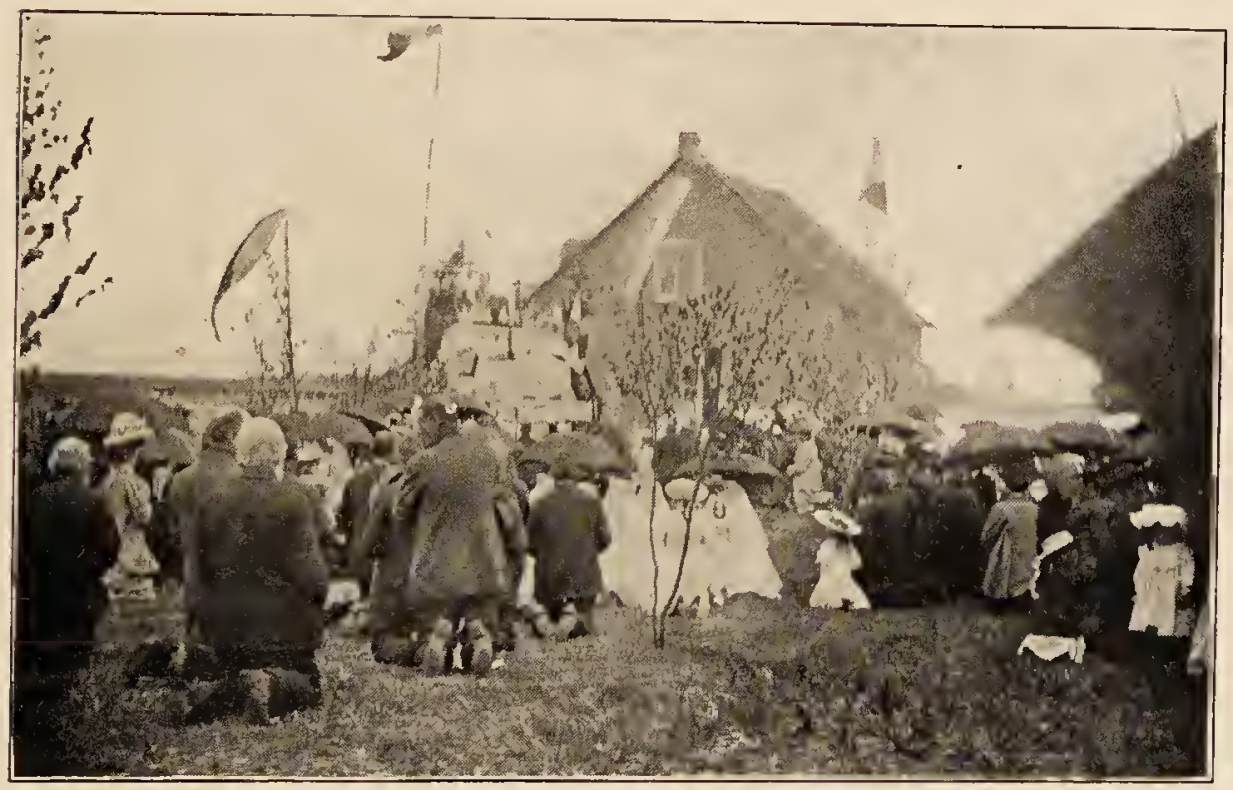

RAISING THE HOST AT THE " REPOSITORY," 



\section{AN ACADIAN VILLAGE}

to the church, had been lined with balsam fir and spruce and birch saplings stuck in the sandy soil and tied to fence posts. The day before, on looking from the door of our house, I had been startled by seeing islands of verdure advancing like Birnam wood across the sound. The islands were boats so filled with trees that the rowers were invisible. Flags and banners of all shapes and colours waved gaily in the wind along this lane and added to the joy and beauty of the scene.

After an impressive vesper service in the church, the whole congregation, which was indeed the entire community, sallied forth on the prepared way. First came an acolyte, a sturdy, handsome youth, bearing aloft in his strong hands the cross, and attended by two smaller boys bearing candles. All the acolytes were resplendent in scarlet cassocks and white lace cottas. Then followed all the little children of the village marshalled into some sort of order by two anxious nuns, the boys in one line, the girls in another. The image of the virgin, borne on the shoulders of two women and attended by little girls in the bridal dresses of their first communion, came next. Behind followed the 


\section{A LABRADOR SPRING}

women, young and old, many with babes in arms. The central figure of the procession was the priest dressed in gorgeous vestments and bearing the host. He strode along under a canopy supported by four sturdy fishermen, preceded by a banner, a company of men singers, and four large candle-lanterns, raised aloft on poles by four white-bearded men. Seven boys in scarlet and white took their appointed positions in the group. Behind the priest followed the long throng of men, all bare-headed, with whom I reverently joined.

Along the narrow, sandy lane we slowly walked. Great solemnity, piety and adoration of the sacred services were shown on every face. There was no levity, no idle conversation; there were no lookers-on, all were participants. The men sang, the priest intoned, the bells in the steeple rang forth; a fox sparrow's flutelike tones issued from the brook-side, clear and sweet, and the holy vespers of the hermit thrush came faintly from the distant forest. At last we reached a turning in the lane where the priest entered a repository, gayer still with flags and bright pictures, images and paper flowers, and with carpets placed about. Here, 


\section{AN ACADIAN VILLAGE}

after a short service, the host was raised and the prostrate people blessed. Again the journey was continued over a little bridge to another repository, where the same service was repeated. Again the church bells jangled forth, and the procession slowly wound its way to the bridge by the church, and so on into the sacred edifice. Here the services were completed with much burning of incense and music.

To even think of photographing such a holy procession seemed sacrilegious, but on inquiring beforehand, I had learned that the good father would consider it a privilege if some photographs could be obtained of such an event, as cameras were unknown in the village. So from time to time my friend and I slipped from the ranks of worshippers and endeavoured to fasten on the photographic films some records, however imperfect, which might remotely suggest the simple piety and beauty of the scene.

It was with regret that I left this little Acadian village with its simple, peaceful life. One of the first settlers who had brought his family from the Magdalen Islands is reported to have said in reply to a question by Abbé Ferland as to his reasons for leaving long-settled regions 


\section{A LABRADOR SPRING}

for the wilderness: "The plagues of Egypt had fallen upon us. The first three came with bad harvests, the seigneurs, and the traders; the remaining four arrived with the gentlemen of the law. The moment the lawyers set their feet upon our island there was no longer any hope left of maintaining ourselves there." Fortunately his animadversions were not extended to any other profession, so I was always treated with the politeness that is characteristic of the race. May the simple life long continue on these shores! 


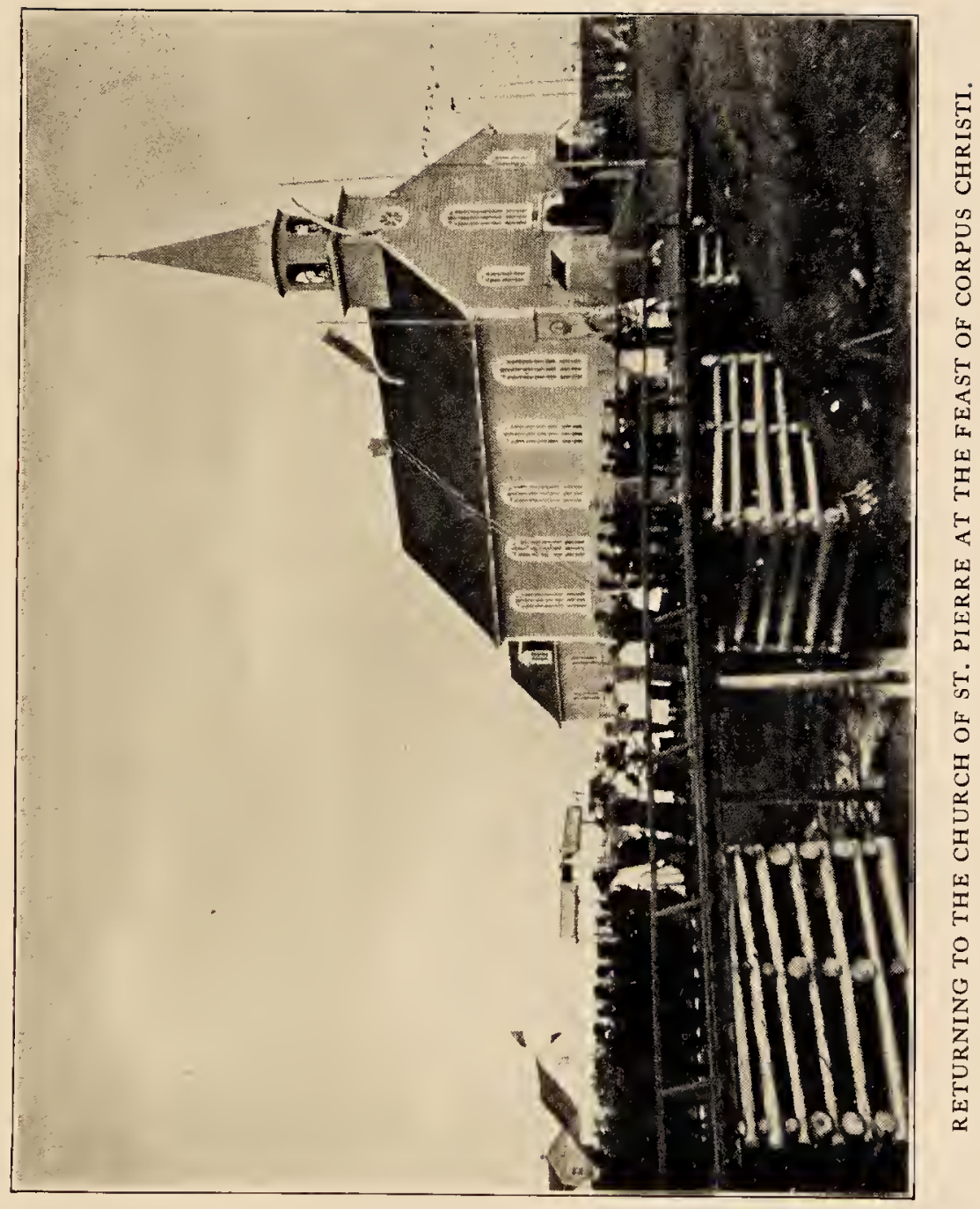





\section{CHAPTER IV}

THE COURTSHIPS OF SOME LABRADOR BIRDS

"Mille modi veneris."

- Ovid.

$\triangle$ MONG the primitive races of mankind $\mathcal{A}$ the male as a rule adorns himself more than the female. He it is that rejoices more in tattoo markings and paints, in the beauty of the dressing of his hair and in adornments by bright feathers. The female is modest by comparison and quiet in her savage apparel. Among the lower animals this adornment in the male is, with a few exceptions, the rule. The stag with his great antlers is a striking object beside the demure doe. Among the birds the contrast between the sexes is still more emphasized, and the brilliantly coloured cock often appears to belong to a different race from the quietly dressed hen. The most striking contrasts are to be seen among the famous birds of paradise 


\section{A LABRADOR SPRING}

where the females are as dull coloured and inconspicuous as sparrows.

That all this is very different from the present day fashion among civilized mankind is of course a trite observation, but one wonders whether the old instinct is not still present, for men. when away from the restraints of conventionality, love to adorn themselves with striking raiment, as witness the cow-boy and the tourist-sportsman, while it is an open question whether men are not naturally more attracted by the women quietly but carefully and tastefully dressed, than by the woman whose garments suggest the male bird of paradise. Most women think otherwise, if we are to judge from outward appearances, but I am inclined to think they do not understand men, and are ignorant of this deep, inherited taste.

One of the most marked examples of the adornment of the male and of the quiet dress of the female among birds is the eider, a common and characteristic duck of this Labrador coast. The male is indeed a striking bird; he is a splendid duck of large proportions with a creamy white upper breast and back. His wings, tail, lower breast, belly and top of his 


\section{COURTSHIPS OF LABRADOR BIRDS}

head to just below the eyes are jet black, while the sides of his face and the back of his head are washed with a most delicate and lovely shade of green. Seen from the side, when he swims on the water, the black crown, wings and tail contrast beautifully with the general whiteness of the rest of the plumage. From behind, the black crown is seen to be carefully parted by a white line in the centre, while the black wings and tail, separated by a white division, make a striking pattern. In flight, the black belly and white breast are conspicuous, an arrangement the reverse of the usual in bird colouration.

The female eider, on the other hand, effaces herself in a garment of brown, so that she is often invisible against the dark water, while her mate shines forth conspicuously. One may see at a distance a company of eiders all apparently males, but on nearer approach the company is found to contain a number of females, which were at first invisible owing to their plainer colouring. To their mates these lady eiders must appear very charming, and indeed to human eyes, the beauty of the plumage of the females must be granted, for, when seen at close range, they show most wonderful 


\section{A LABRADOR SPRING}

pencillings of rich brown and black, and each feather is a work of art. The dress is modesty itself, but in richness of colouring and good taste it cannot be excelled. In fact, as a constant companion, I should prefer the richly but modestly dressed duck to the gaudy drake, but this, of course, is my inherited masculine taste, a taste, however, that appears to be shared by the drake.

That the drake is fond of the duck is evident from the love-makings that go on in these cold waters, and indeed the study of the courtships of the eider was one of my greatest interests in this Labrador spring. Everywhere we went among the rocky islands that line the coast, pairs and little bands of eiders abounded. We found twenty nests on one island of a few acres, and, on our walk around Esquimaux Island, we must have seen at least 500 of these beautiful birds. They were usually in pairs, and, when flying, the female preceded, closely followed by the male. This was certainly the rule when the birds were flying about unaware of the presence of man, but, when disturbed or frightened by his presence, I regret to have to state that the male often 


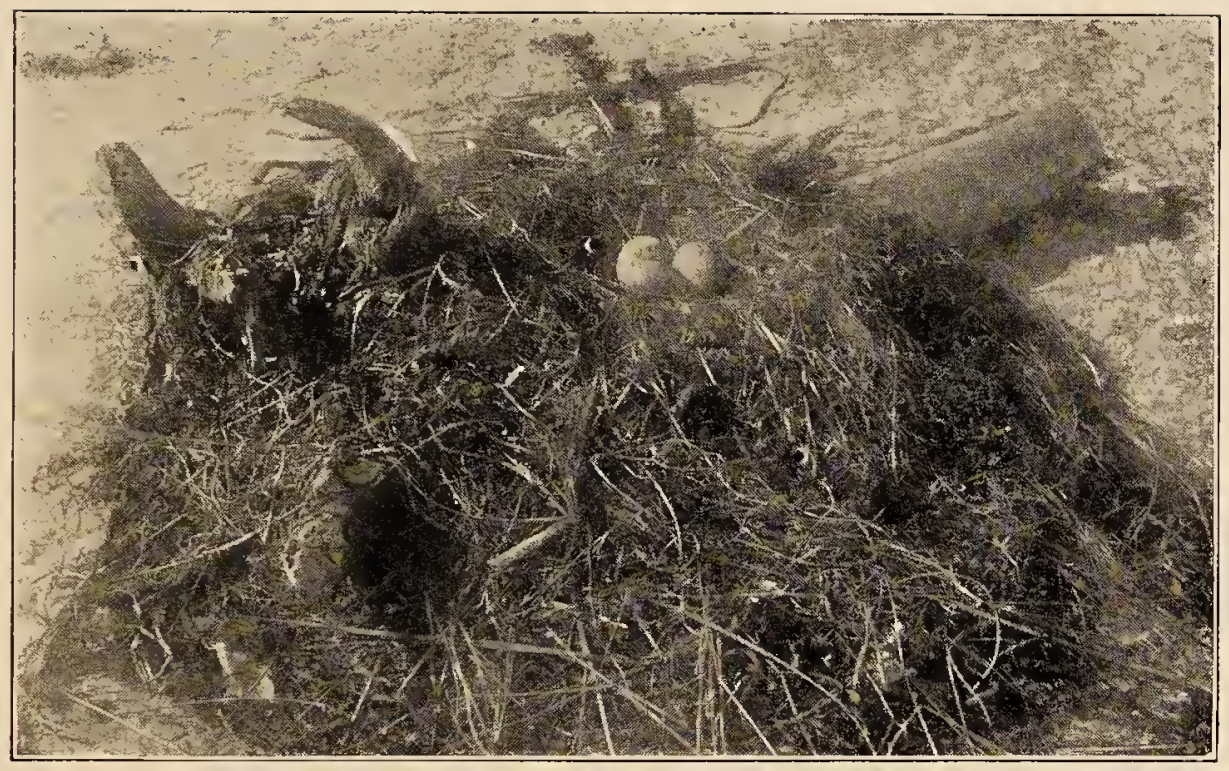

NEST OF GREAT BLACK-BACKED GULL.

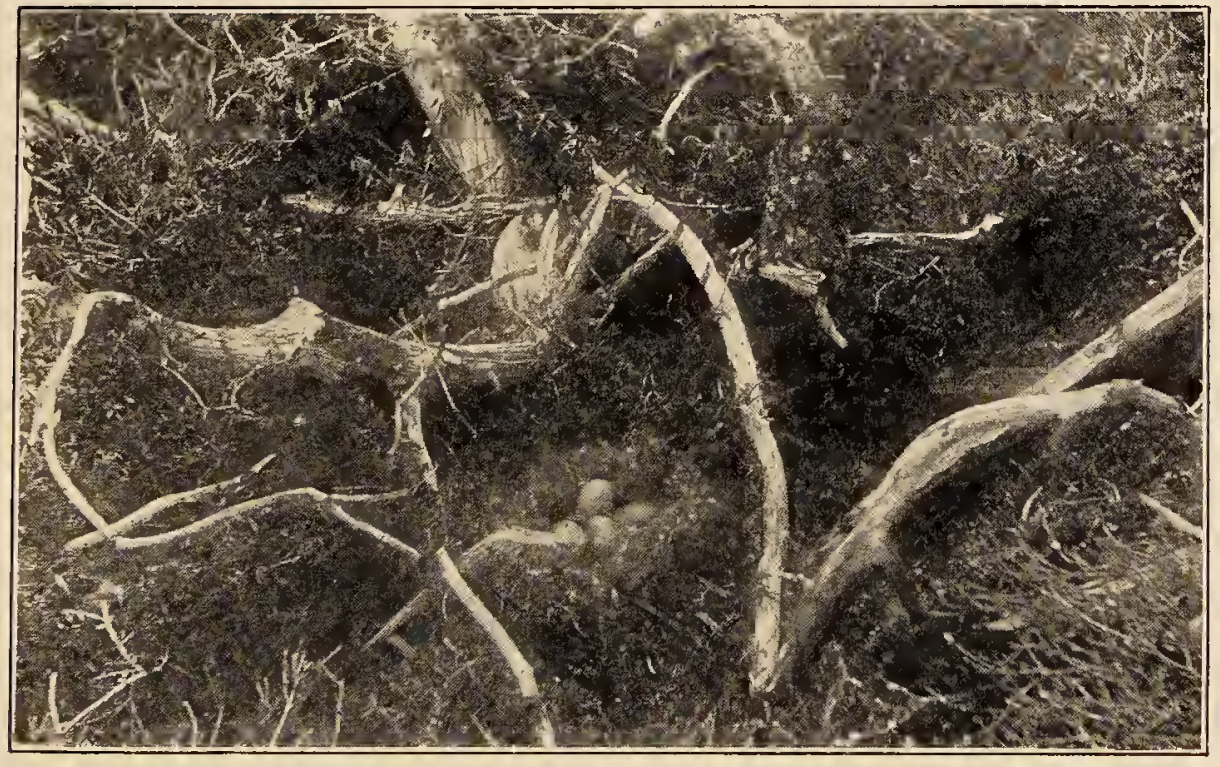

NEST OF EIDER DUCK. 



\section{COURTSHIPS OF LABRADOR BIRDS}

flew first in his eagerness to get away from danger. Sometimes several pairs, apparently mated, would swim about together or rest on the rocks close to the water, while at other times one or two females would be surrounded by six or eight males that were crowding about them to win their favours.

The actual courtship of the eider, or moynak, as it is universally known along this FrenchIndian coast of Labrador, may be recognized from afar by the love-note of the male, a note that Cartwright likened to the cooing of the stock-dove. To me it sounded like the syllables aah-ou, or ah-ee-ou frequently repeated, and, while low and pleasing in tone, its volume is so great that it can be heard at a considerable distance over the water. On a calm day, when there were many eiders about, the sound was almost constant. While the syllables aah-ou express very well the usual notes, there is much variation in tone from a low and gentle pleading, to a loud and confident assertion. In fact the tones vary much as do those of the human voice, and there is a very human quality in them, so much so that when alone on some solitary isle, I was not infrequently startled with the idea 


\section{A LABRADOR SPRING}

that there were men near at hand. To all these pleadings the female remains silent or occasionally utters a low and simple $k u k u k u$.

But the wooer of the demure one does not depend on his voice alone, he displays his charms of dress to best advantage, and indulges in well worn antics. It always seemed to me a pity that the magnificent black lower parts should disappear when the drake is swimming on the water, and the bird evidently shares my sentiments, for during courtship, he frequently displays his black shield by rising up in front, so that at times, in his eagerness, he almost stands upon his tail. To further relieve his feelings, he also throws back his head, and occasionally flaps his wings. The movements of his head and neck are an important part of the courtship, and although there is considerable variation in the order and extent of the performance, a complete antic is somewhat as follows: the head is drawn rigidly down, the bill resting against the breast; the head is then raised up until the bill points vertically upwards, and at this time the bill may or may not be opened to emit the love notes; after this the head is jerked backwards a short distance still rigidly, 


\section{COURTSHIPS OF LABRADOR BIRDS}

and then returned to its normal position. All this the drake does swimming near the duck, often facing her in his eagerness, while she floats about indifferently, or at times shows her interest and appreciation by facing him and throwing up her head a little in a gentle imitation of his forcefulness. ${ }^{1}$

Another duck whose courtship antics are even more interesting than those of the eider is the American golden-eye or whistler, the plon-

${ }^{1}$ Abbott $H$. Thayer's statement in the Introduction to Gerald $H$. Thayer's wonderfully interesting book on "Concealing-Coloration in the Animal Kingdom" that "This discovery that patterns and utmost contrasts of colour (not to speak of appendages) on animals make wholly for their 'obliteration,' is a fatal blow to the various theories that these patterns exist mainly as nuptial dress, warning colours, mimicry devices (i.e., mimicry of one species by another), etc., since these are all attempts to explain an entirely false conception that such patterns make their wearers conspicuous," seems to me hard to believe in the case of the male eider. I have watched this bird on land, on water and in the air, on rocks, in bogs and among bushes both green and brown, among icebergs and ice floes, and, if I were a gyrfalcon intent on eider flesh, I should not wish for a more conspicuous mark. I can not help thinking that the brilliant orange-yellow legs of the male golden-eye, the vivid blue lining of the mouth of the double-crested cormorant and the wonderful black belly-shield of the male eider are instances of the workings of sexual selection. 


\section{A LABRADOR SPRING}

geur of this coast. While the eider makes its nest on the ground often concealed under the grass and bushes, and lays from four to seven large olive green eggs, which it smothers in its own down, the whistler lays six or more pale green eggs in a hollow tree. Of the former we found many nests, of the latter only one, and this was in a large hollow stub about twelve feet from the ground on the edge of a high cliff overlooking the sea near Esquimaux Point. In this well chosen spot, which commanded extensive views of the surrounding country and ocean, a whistler had deposited fifteen eggs and covered them thickly with down.

As the cliff was over a hundred feet high, the process of transfer of the future brood from the nest to the water would have been well worth waiting to see, if only one had had the time. Tree-nesting ducks have been observed to entice the young from the hole, inducing them to drop or flutter down into the grass or the water, and it has been said that they sometimes fly down carrying the young in the bill, or even on the back. Careful observations of these last named methods are, however, few or lacking, and our regret at not being able to stay 


\section{COURTSHIPS OF LABRADOR BIRDS}

and watch the process was therefore the greater.

Although I did not observe the courtship of the whistler in Labrador, and its extreme shyness is probably the reason that so little has been written on the subject, I have observed it at Ipswich and Barnstable in Massachusetts, and especially in the Charles River Basin at Boston where, owing to the protection afforded by the great city, the birds are unusually tame and unsuspicious.

The spring is of course the time when the courtship actions are most indulged in, and they begin in mild days in February and continue until the departure of the birds for the north early in April. In the autumn months, however, it is not uncommon to see the same performance given both by the adults and young males, although but incompletely carried out in the latter case.

The courtship action varies considerably, but a typical and complete one may be described as follows: One or more males swim restlessly back and forth and around a female. The feathers of the cheeks and crest of the male are so erected that the head looks large and 


\section{A LABRADOR SPRING}

round, the neck correspondingly small, and as he swims forward the head is thrust out in front close to the water, occasionally dabbing at it. Suddenly he springs forward elevating his breast, and at the same time enters on the most typical and essential part of the performance. The neck is stretched up, and the bill, pointing to the zenith, is opened to emit a harsh, rasping, double note, zzee at, vibrating and searching in character. The head is then quickly snapped back until the occiput touches the rump, whence it is brought forward again with a jerk to the normal position. As the head is brought to its place, the bird often springs forward, kicking the water out behind, and displaying like a flash of flame the orange coloured legs. This appears to be the complete performance, and the female although usually passive, sometimes responds by protruding her head close to the water in front, and then bringing it up so that it also points to the zenith. Further than this, I have not seen her go. It must be remembered that even as late as March there are many young males whose plumage resembles that of the female, although the males are of larger size, yet it is often difficult to distinguish them from the 


\section{COURTSHIPS OF LABRADOR BIRDS}

female. That the female does take part to this limited extent in the nuptial performance, I have, however, convinced myself. Although this performance is more striking than that of the eider just related, the family resemblance can be detected.

There are many variations of this curious action. It may be curtailed, so that the thrusting of the head up into the air alone remains, or it may be limited to the upward thrust of the head and the jerk to and from the rump. When the birds are at such a distance that the note can not be heard, it is impossible to say when it is emitted, but I have observed birds close at hand go through the performance silently. I have also seen them thrust out the head in front in such a way as apparently to scoop up the water and then elevate the head, the bill pointing straight up but closed as if they were drinking the water. Sometimes the head is held on the rump for several seconds before it is snapped into place.

A male after ardently performing the courtship actions near a female flew off with his head low about a hundred yards. The female swam rapidly after him with head stretched 


\section{A LABRADOR SPRING}

close to the water, but lifted up vertically from time to time in the courting manner, and she soon joined her mate.

The display of the brilliant orange legs and feet by the males is particularly interesting. These members in the female are pale yellow in colour, and it may be supposed that the males have attained the more attractive orange as a result of sexual selection. They certainly make good use of this brilliant colour in the courtship display, for the flash of the orange feet contrasting with the snowy flanks of the bird and the dark water is extremely effective, and noticeable even at a considerable distance. In this connection it is interesting to note that the legs and feet of both male and female Barrow's golden-eye are alike pale yellow. I am not familiar with the courtship of this bird, and as far as I know it has never been described, but I think it is reasonable to infer that the display of the legs, as in the American goldeneye, is not a part of the performance. As the Barrow's golden-eye lacks the peculiar localized swelling of the lower wind-pipe found in the other species, one might suppose that the musical part of the performance was also 


\section{COURTSHIPS OF LABRADOR BIRDS}

lacking in their case. A study of the courtship of this very similar yet very different bird is much to be desired, and might throw considerable light on the relationships or evolution of the two species.

There is no more unusual and bizarre sight in the bird world than a dozen or more beautiful whistler drakes crowding restlessly around a few demure little females, and displaying these antics of head, neck, and feet, while ever and anon their curious love-song pierces the air.

At Esquimaux Point on June 2nd, as I was standing on the rocks on the shore, I was startled by the loud quack or croak characteristic of the female black duck, and looking up I saw two large black ducks, evidently males, in close pursuit of a smaller female. They doubled and twisted in a manner wonderful to see, as the duck appeared to be straining every nerve to elude the drakes. At last one of the drakes gave up the pursuit and disappeared over the low forest, whereupon the other drake and duck sailed away together, as if it had all been arranged beforehand, straight to a secluded pool out of sight behind the rocks. The whole affair was of short duration but very exciting 


\section{A LABRADOR SPRING}

while it lasted, and very decisive; one of the drakes had to be rejected.

Another water bird whose courtship I watched on the Labrador coast was that curious individual - that compound of dignity and comicality - the puffin. On this coast the bird is universally known as the "perroquet," but Sir Richard Bonnycastle in his "Newfoundland in $\mathrm{r} 8{ }_{42}$ " justly says it " may be called the sea-owl, from its extraordinary head and wise look." Near Bald Island they delighted to gather on the water in compact parties of fifty or sixty individuals, that were constantly moving in and out like a crowd at an afternoon tea. Every now and then one would sit up on the water and spread its wings, and once I watched two fighting with flapping wings, and, at another time, two struggling together for a full minute with interlocked beaks. Occasionally one puffin would face another, and throw its head back with a quick jerk so that the bill pointed vertically up, and then lower it again. At one time I saw several birds do this, but as the wind was strong, the water rough and the distance considerable, my observations were far from complete and satisfactory. Edmund 


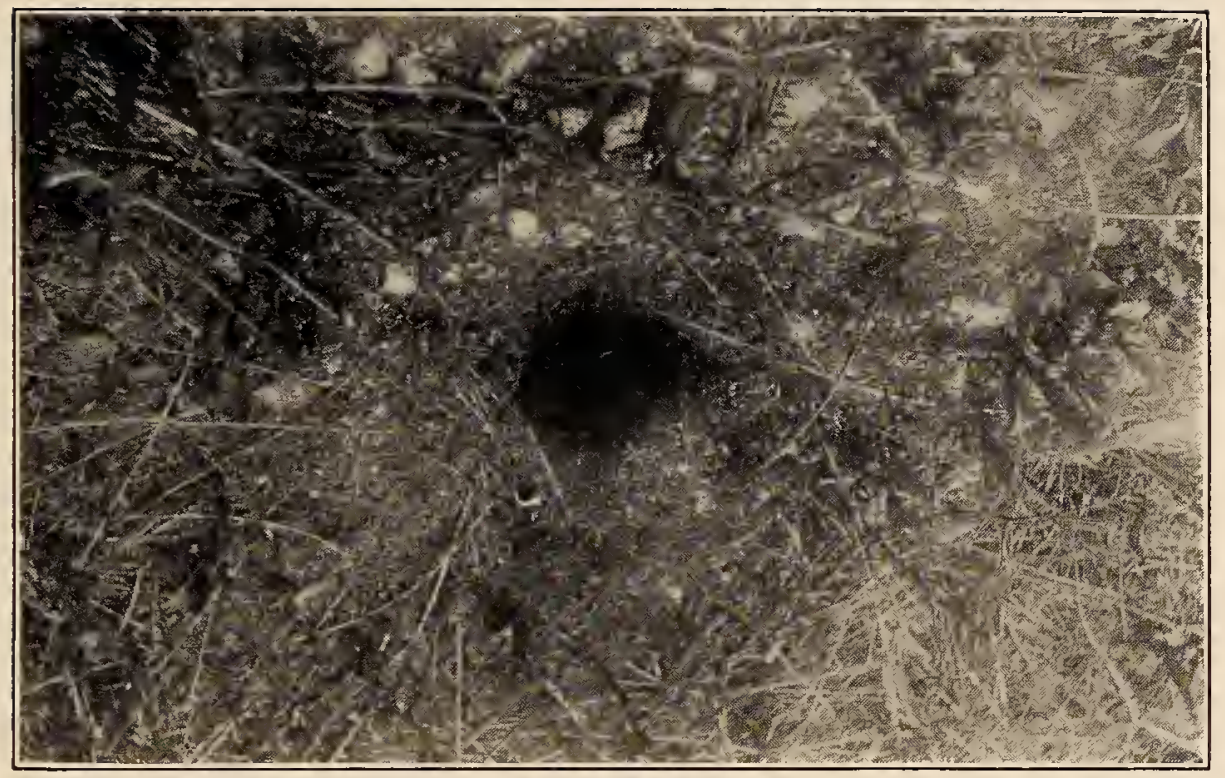

ENTRANCE TO PUFFIN BURROW, BALD ISLAND.

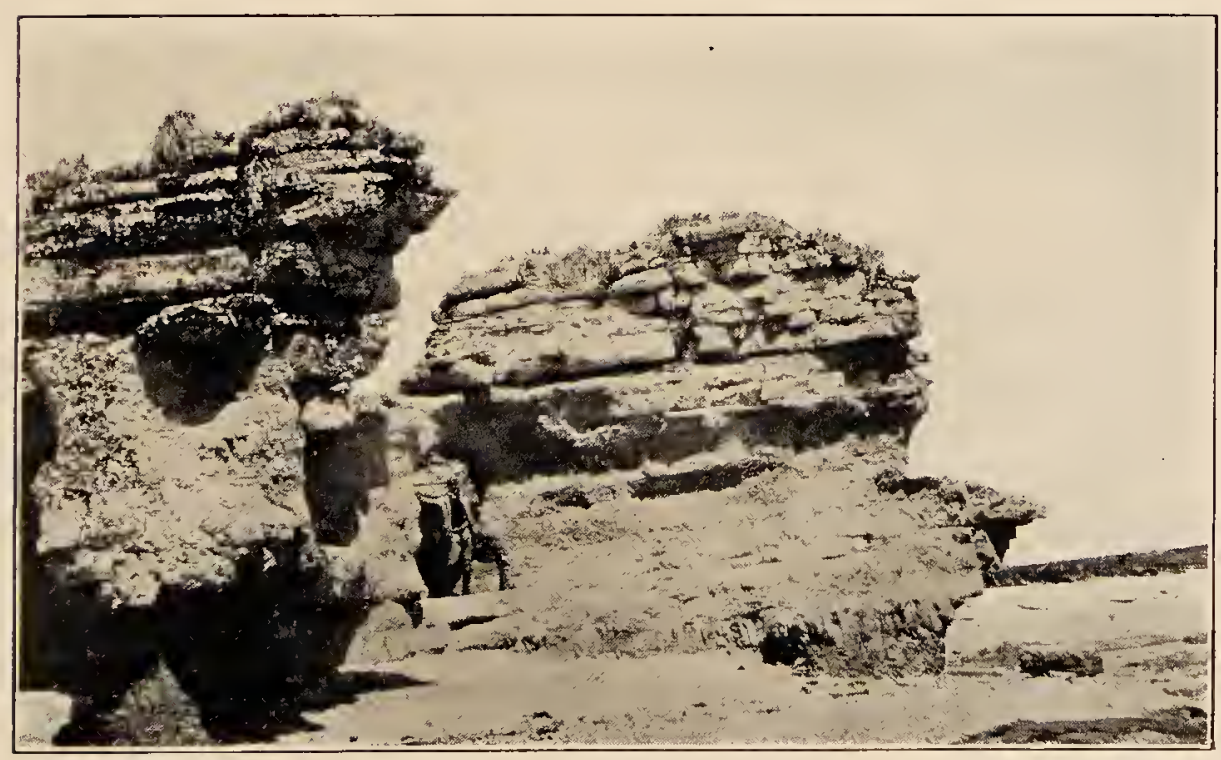

WATER WORN LIMESTONE ROCKS AT BALD ISLAND. NESTING SHELVES FOR RAZOR-BILLED AUKS. 



\section{COURTSHIPS OF LABRADOR BIRDS}

Selous, ${ }^{r}$ who has watched sea-birds in the Shetlands, says of the puffin: "One of the birds, standing so as directly to face the other, will often raise and then again lower, the head, some eight or nine times in succession, in a half solemn manner, at the same time opening its gaudy beak, sometimes to a considerable extent, yet all the time without uttering a sound." Not only is the outside of the beak gaudy in scarlet with white and blue lines, but the inside with its brilliant yellow lining is superlatively so, and is probably, as Selous suggests, developed as a result of sexual selection. The inside of the mouth of the double crested cormorant is a vivid blue - that of the European shag described by Selous is curiously enough a "bright gamboge yellow" - while on opening the mouth of a black guillemot I found it to be scarlet. All these birds open wide the beak in courtship, according to Selous.

Among many of our smaller birds it frequently happens in the height of the spring season and in the ecstasy of their passion that they rise into the air with rapidly fluttering

${ }^{1}$ The Bird Watcher in the Shetlands. London, I905, p. 246 . 


\section{A LABRADOR SPRING}

wings as they pour forth their love-song. This happens regularly in the case of such birds as the pipet, the horned-lark and the long-billed marsh wren, and less regularly in the song sparrow, oven bird, and Maryland yellowthroat.

In these cases the slight music made by the rapid and forcible fluttering of the wings is wholly subordinate to the song. In the case of the ruffed grouse on the other hand, the music of the wings is everything, there is no vocal music and no locomotion, for the bird stands on a $\log$ and flutters its wings so rapidly that a loud whirring or "drumming " sound is made, by which the bird expresses, doubtless, the same emotions as are expressed by the fox sparrow with its wonderful song.

Mr. William Brewster, in his description of a drumming grouse, says: "Suddenly he paused and sitting down on his rump and tarsi, crosswise on the $\log , \ldots$ he stretched out his wings stiffly at nearly right angles with the body. . . . Now the wings were drawn slightly back, a quick stroke given forward, at the air, and a pulsating throb, entirely different from any sound I have ever heard, struck my ear, pro- 


\section{COURTSHIPS OF LABRADOR BIRDS}

ducing at such short range an almost painful sensation: the wings were immediately recovered, and another stroke, a trifle quicker than the first, was succeeded by another still quicker, until the wings vibrated too fast to be followed by the eye, producing the well-known terminal roll of muffled thunder."

Although this performance is very different from the fluttering flight of the singing bird, yet there are two other Labrador birds that illustrate very well, it seems to me, the stages in its evolution. One of these is the willow ptarmigan, which, we were told came to the southern coast in great numbers every five or six winters. In this season the bird is snow-white with the exception of a black tail, but in summer it is brown and matches so well its surroundings that it is almost impossible to see it on the ground. In the love season it does not drum like its cousin the ruffed grouse, neither does it sing, in fact it tries to do both, but, as is often the case under these circumstances, it falls between two stools and does neither well. Mr. L. M. Turner thus describes the nuptial performance of the willow grouse, as he observed it in Labrador:"In the spring these birds repair, as the snow 


\section{A LABRADOR SPRING}

melts, to the lower grounds and prepare for the nuptial season. About the roth of April they may be heard croaking or barking on all sides. A male selects a favourable tract of territory for the location of the nest, and endeavours to induce a female to resort to that place. He usually selects the highest portion of the tract, whence he launches into the air uttering a barking sound of nearly a dozen separate notes, thence sails or flutters in a circle to alight at the same place whence he started, or to alight on another high place, from which he repeats the act while flying to his former place. Immediately on alighting, he utters a sound similar to the Indian word chu-xwan (what is it?) and repeats it several times, and in the course of a few minutes again launches in the air."

The second stage in the evolution of the drumming performance is illustrated by the Canada grouse or spruce partridge, who has developed the wing music to such an extent that he has given up the vocal music. The wing music, however, appears to be still somewhat dependent on flight and has not advanced to the stage seen in the ruffed grouse, where the wing music has become a performance in itself 


\section{COURTSHIPS OF LABRADOR BIRDS}

and not incidental to flight. Although we saw a number of spruce partridges in various places on the coast, and although we watched and listened eagerly for their nuptial performance, we were unsuccessful. Bendire quotes the following description of the act: "After strutting back and forth for a few minutes, the male flew straight up, as high as the surrounding trees, about i 4 feet; here he remained stationary an instant, and while on suspended wing did the drumming with the wings, resembling distant thunder, meanwhile dropping down slowly to the spot from where he started, to repeat the same thing over and over again." He also quotes another description of the drumming as follows: "The Canada Grouse performs its 'drumming' upon the trunk of a standing tree of rather small size, preferably one that is inclined from the perpendicular, and in the following manner: Commencing near the base of the tree selected, the bird flutters upward with somewhat slow progress, but rapidly beating wings, which produce the drumming sound. Having thus ascended 15 or 20 feet it glides quietly on wing to the ground and repeats the manœuvre." 


\section{A LABRADOR SPRING}

Whether in the future ages the ptarmigan will reach the stage of the spruce partridge, and the latter that of the ruffed grouse, or whether they will each branch out on original lines of their own, time alone will determine, but in the present age they represent very well different stages in the evolution of the wonderful performance of the ruffed grouse. 


\section{CHAPTER V}

THE CRUISE OF LA BELLE MARGUERITE FROM ESQUIMAUX POINT TO NATASHQUAN

" Through the Northern Gulf and the misty screen Of the isles of Mingan and Madeleine."

- Whittier.

1 HE Labrador Coast from the base of the Peninsula to Cape Charles at the entrance of the Straits of Belle Isle is nearly 600 miles in length, and from Cape Charles to Cape Chidley at the northern extremity of the eastern coast the distance is about 700 miles. With a few insignificant gaps this entire coast line of over one thousand miles is so beset with islands that it is possible to cruise in a small boat in protected water-ways nearly the whole distance. One must bide one's time, however, in the gaps, for in the Gulf of St. Lawrence as well as on the Atlantic Coast the seas are often of the stormiest.

At Esquimaux Point, with the kind assist103 


\section{A LABRADOR SPRING}

ance of the government physician, Dr. Tremblay, we were put in touch with two good men, Mathias and Martial, owners of a fishing-boat, with whom we proposed to cruise along the coast to the eastward, stopping wherever we wished and exploring all places of interest. The boat was like all the fishing-boats of that shore, staunch and seaworthy, thirty feet long and pointed at the ends like a canoe or ancient caravel. I suppose its model dated back to European ones, although an evolution from the Indian canoe at once struck my fancy. The birch canoe of the Indians in this region has been replaced by them with one of the same model but covered with painted canvas. The ease with which canvas can be obtained as compared with birch bark of the proper size, its lightness and strength and resistance to injury, has endeared the canvas canoes to the Indian, as well as to the white. The next step in the evolution is the wooden canoe, a stauncher and stronger boat and useful on the sea, one that is propelled both by oars and paddles. From that to the strong canoe-shaped rowing boats used as tenders by the fishermen here seems also a simple step, while the large sailing boat 


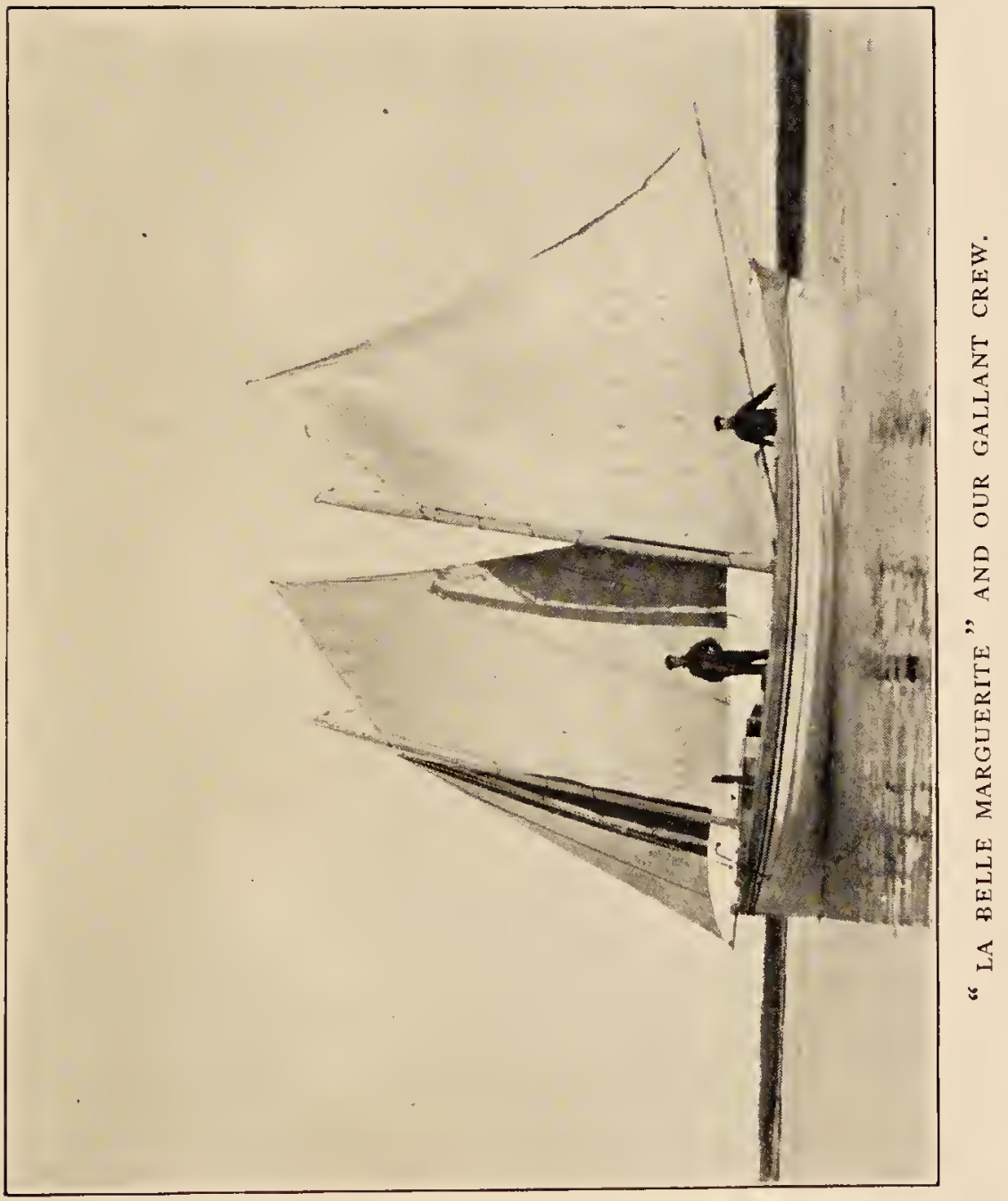





\section{CRUISE OF LA BELLE MARGUERITE}

with its pointed ends appears to be but an amplification of the tender.

Our boat or barge, as it was technically called, was decked over and provided with a small cock-pit astern, and an equally small cabin or cuddy in the bow. It was schooner-rigged with two masts, and, although the owners took great pride in the white sails, and said the boat could therefore sail the faster, I myself regretted that the sails were not stained a picturesque red, or pink, or brown, as were those of many other barges in this region. Some of these stains were wonderful bits of colour, shading like a water-colour wash from dark mahogany in one part of the sail, to a light pinkish hue in another part. Others were more uniform, but the effect was always pleasing and suggestive of the colouring of the sails in far less rugged and more smiling waters.

In the cuddy of our boat was a tiny iron stove, which, however, took up so much of the little room that there was but space for one man to lie out at length on that side, and here my friend made his bed. On the other transom Mathias and Martial by overlapping end to end were able to sleep, and sleep they did there 


\section{A LABRADOR SPRING}

every night on the narrow shelf as quietly as babies. A small triangle of floor was left between on which a child of six might have been able to lie at length, and which Martial explained by expressive pantomime made an excellent bed if one sat up and leaned against the mast.

Guns, charts, food, cameras, clothing and materials for preparing specimens took up all available space not devoted to sleeping and cooking, but by a little care in managing, we were able to live very comfortably. It certainly simplifies life to have, as Martial expressed it, la salle d̀ manger, la salle à fumer, la chambre à coucher, le salon et la cuisine all together. One could put one's hand on every thing from a central point. According to Dr. Grenfell, there is a Labrador beatitude which says: "Most blessed is the man who can get along with least things."

Although there was plenty of air in these somewhat confined quarters, and it was always cold at night, I preferred all out of doors for my chambre à coucher, and, provided with a sleeping-bag and a bed of balsam boughs carefully thatched on the deck, I enjoyed this chambre to my heart's content during the cruise. 


\section{CRUISE OF LA BELLE MARGUERITE}

A sleeping-bag is a delightful thing in a cold climate; one dresses instead of undressing for bed, and puts on all the clothes he has, if his blanket is thin, while going to bed is very much like crawling into a hole and pulling the hole in afterwards, a thing most of us would like to do metaphorically from time to time.

To sleep out under the stars in cool, pure air, free from mosquitoes or flies of any sort, to breathe in the fragrance of the balsam and the sea, to be gently rocked by the subdued ocean waves in protected harbours, to be lulled to sleep by the lapping of the water against the boat's sides, by the calls of the spotted sandpiper and the evening hymn of the robin, to awake to the song of the fox sparrow and the whitethroat on the shores, and the love-cooing of the eider on the water, - this was indeed good and productive of heart's content.

Such a boat as this should needs have a name, but the need apparently had not occurred to the owners. I asked, therefore, the name of one of the daughters of Mathias, who, in preparation for the cruise, was diligently scrubbing the cabin at the moorings off Esquimaux Point, and at once with due solemnity christened the 


\section{A LABRADOR SPRING}

boat "La Belle Marguerite," choosing the name the more readily as one of my own also bore it.

From Esquimaux Point we set sail in "La Belle Marguerite" with a good breeze on May

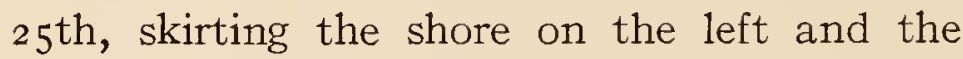
islands on the right, successively passing Esquimaux Island, Sea Cow Island, Charles Island and Hunting Island, all of the Mingan group. At times it seemed more like sailing in inland lakes than in the sea. The second of these islands just mentioned takes its name, not from the sea-cow or manatee, but from the walrus which formerly extended its range from the arctic regions along this Labrador coast, but is now never seen there except in the most northern portions of Labrador.

From Esquimaux Point a beach extends eastward for twelve miles or more, backed by a sand and clay cliff, brown and white and gray, which increases in height towards the eastwards, where it reaches an elevation of a hundred and twenty-five feet. Here, as we afterwards discovered, bank swallows had made their nesting holes, and about sixty of these little birds, uttering their rasping chirps, were flying about. How they manage to dig their 


\section{CRUISE OF LA BELLE MARGUERITE}

deep holes in the hard bank with their feeble claws and bill is always a mystery. It only shows what persistence will do, and the same lesson was taught by the great cross gullies, or canyons, made in these cliffs by little rivulets, that had been slowly cutting down to sea level, or perhaps had always remained at sea level as the cliffs were gradually elevated.

On the way we stopped to watch a single northern phalarope, sitting like a miniature swan in the water and pirouetting about in the stormy waves. The bird proved to be a female. It is interesting to remember that among the phalaropes the females are larger and more brightly coloured than the males, that they do the courting, and that they leave to the downtrodden husband the duties of incubation and care of the young. They are suffragettes with a vengeance.

At Faux Pas Island, a gravelly and grassy bank of a few acres in extent, we landed and feasted our eyes on our first saddle-back's or great black-backed gull's nest. A conspicuous object it was, over four feet across, made of roots, grasses and seaweed, and built over a derelict tree trunk. Inside it measured ten 109 


\section{A LABRADOR SPRING}

inches in diameter, was lined with fine grasses and contained three great eggs, olive-green in colour, beautifully decorated with large brown spots. After this we found many of these nests, - nearly every island contained several of them. Some of the nests consisted only of depressions in the turf surrounded by rings of particularly green grass, nests that had probably been used for successive years. We were rarely out of sight or hearing of these splendid birds all the time we were in Labrador, even when we were trudging over the inland bogs. Splendid great birds they were indeed with their snow-white heads, breasts and tails, and their black backs and wings, and they recalled slightly by their size, colouring and majestic flight the bald eagle. Their calls were interesting and very various. Some were suggestive of human anger or grief or derision. At times their voices appeared to threaten, at times to deride, and again they appeared to be conversing in low tones to each other as they flew overhead or sailed about gracefully in the strong winds. Hoarse $h a, h a$, ha, high pitched $k i, k i, k i$, harsh and croaking caw, caw, caw, were some of their calls I noted, and sometimes 
CRUISE OF LA BELLE MARGUERITE

they cried car-ca-son most distinctly. That evening we anchored behind Hunting Island in the sheltered harbour of Betchewun, and paid our respects to the solitary inhabitant.

Again we were off, and this time, taking advantage of the calm water in the early morning, we laid our course for Seal Rock, which was a barren lime-stone rock, one of the last of the Mingan group. Not altogether barren this rock proved to be, however, for, although only about an acre in extent, it could be seen even from a distance to be covered with black objects, which stretched up their necks in alarm at our approach. Suddenly about 400 birds, - double-crested cormorants or shags as they are also called, - sprang into the air and flew about over our heads, for the most part silent but occasionally uttering hoarse croaks. Weird birds they are, with long, snake-like necks and great feet like bat's wings, with webs connecting all their toes. Their black plumage, showing a purple metallic sheen, is relieved by orangecoloured patches of bare skin at the throat, at the base of the bill and in front of the eye. Their eyelids are black with a beading of blue spots, while the eyes themselves are emerald- 


\section{A LABRADOR SPRING}

green. The inside of the mouth is one of their greatest charms, and, according to Selous, is displayed during courtship; it is coloured a vivid, theatrical blue, which contrasts in a striking manner with the bare, orange throat. How irresistible a cormorant beau must be when he casts his jewelled eyes at his lady love, and opens on her the blue grotto of his mouth! To complete his charms, he is provided with two little tufts of feathers, one either side of his head, from which he gets his specific name.

From afar we scented their domiciles, for an all pervading " ancient and a fish-like" smell rose upon the air. We counted 204 nests, basket-like structures six inches to a foot high and a foot and a half across, made of sticks and seaweed cunningly woven together and lined with grasses. Some were decorated, - I use the word advisedly, - with large gulls' feathers, and many with branches of evergreen, balsam, fir, spruce, juniper and laurel. Nearly all contained eggs, chalky white and dirty, from one to five in number. One needed a strong stomach and a sure foot to walk about these rocks slippery with " la farine des cormorants," which painted rocks and nests alike a 
CRUISE OF LA BELLE MARGUERITE

dirty white colour. At last we finished our work of counting, photographing, and notetaking, and, as we departed, we were glad to see the great black aeroplanes sail gracefully down to their unsavoury abodes.

"As with his wings aslant, Sails the fierce cormorant, Seeking his rocky haunt, With his prey laden,"

Milton in "Paradise Lost" offers a tribute to the uncanny nature of this bird, when he says of Satan:

"Thence up he flew, and on the tree of life, The middle tree and highest there that grew, Sat like a cormorant."

After this we hoped to explore Bald Island, the home of the puffins, but the wind proving unfavourable we deferred this visit for a future time, and again turned our prow eastward and soon passed a solitary house on the rocky shore, which was used in the lobster fishery. Here, beginning the first week in June, lobsters are caught and canned. Farther to the eastward near the mouth of the Corneille River is another house used by salmon-fishers. At last 


\section{A LABRADOR SPRING}

we came to anchor in a lovely land-locked harbour among Les Isles des Corneilles, and here we spent a most interesting twenty-four hours, exploring the low, rounded granitic islands and the main land with its salt marshes, its bogs, its impenetrable forests and its rushing turbid river.

Eiders were everywhere and their love notes were constantly in our ears. They were to be seen not only on the water, but also on the rocks and among the stunted spruce bushes of the islands where we frequently stumbled on their nests, the large olive-green eggs concealed in a mass of soft eider down.

A flock of twenty-eight geese were feeding in a shallow pool between two islands, and, as I watched them from a sheltered sunny nook beside a great snowbank, I listened to the songs of the melodious sparrow family as represented by the white-crowned, white-throated, tree and fox sparrows, all good singers. To the majority of people the word sparrow calls up only the English sparrow of our streets with its nerveracking chirps! Little do they know how musical are most of this tribe and what a great tribe it is. 


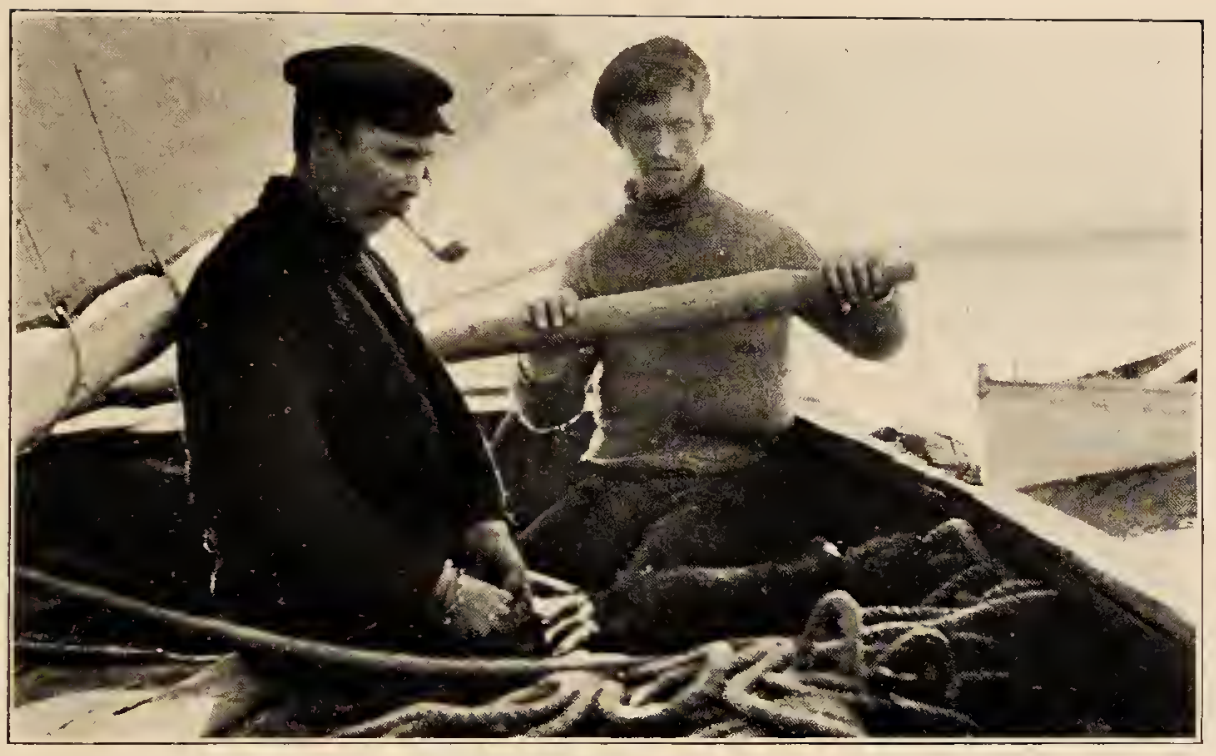

MATHIAS AND MARTIAL AND THE BंEAVER.

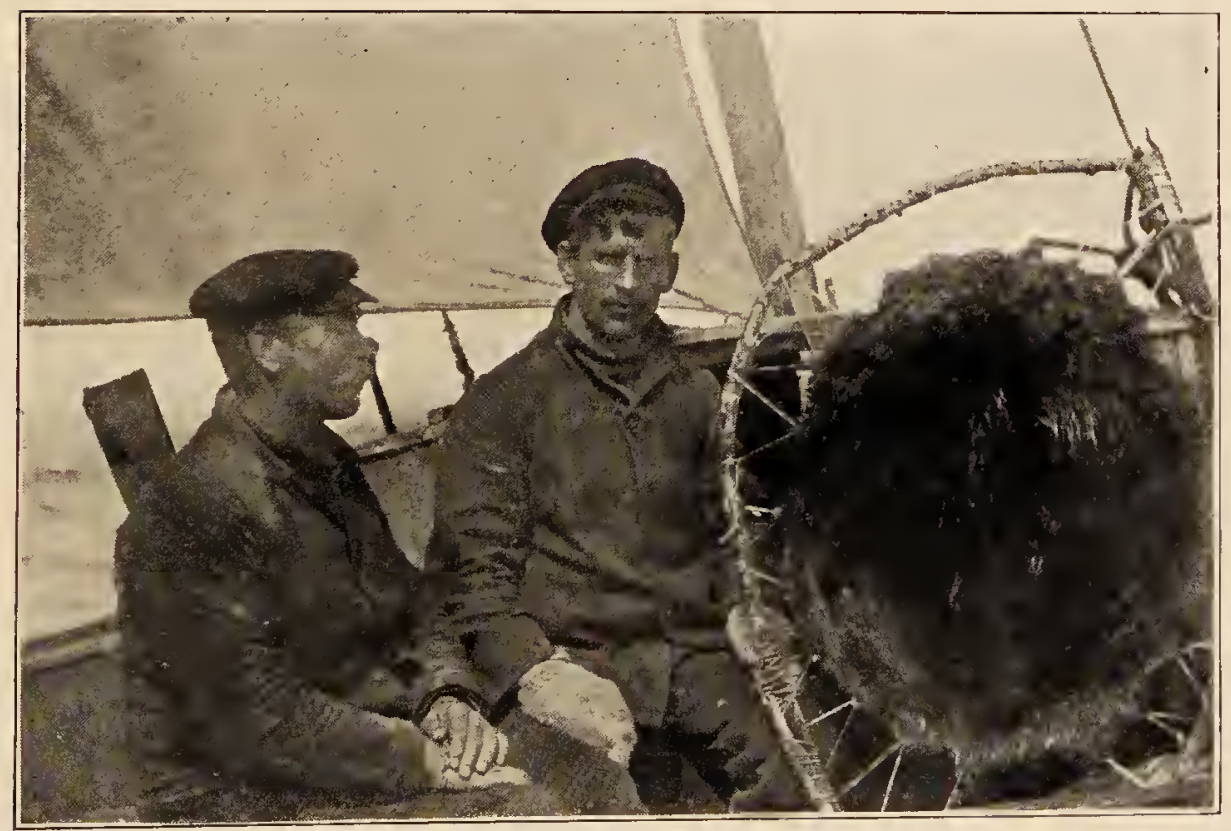

THE BEAVER SKIN. 



\section{CRUISE OF LA BELLE MARGUERITE}

It was here in the little harbour of the Crow that Mathias, he of the brass bracelet to keep off rheumatism and salt-water sores, cried out "Les Sauvages!" and here I made my first visit on these interesting people.

Again we bore away, and this time for $\mathrm{Pi}$ ashte-bai Bay, at whose mouth we visited a solitary Indian wigwam, and spent part of two days with a fur-trader, visiting his house, ascending the river to the falls and gathering much interesting information.

While we were on the shore we met one of the inhabitants returning from his traps with a large beaver on his back, and, on our return to "La Belle," we found that the men had shot another as it was swimming across the harbour. They are interesting beasts, these beaver, from many points of view, historical and otherwise, and that night I learned some new facts. With great care Mathias prepared the tit-bit, the tail, for supper. First he roasted it slightly over the embers, so that the black, scaly skin could be easily scraped off; then with an axe he cut up the white meat into little cubes, and boiled it in a sauce-pan. 'It tasted something like pigs' feet, and although good eating, was not as 


\section{A LABRADOR SPRING}

pleasant to my palate as beaver steaks, which were delicious and suggested goose. As we were eating I suddenly remembered it was Friday, and feared our good friends were committing a grievous sin. Not so, however, for, as Mathias explained, beaver is poisson, as is also the moynak or eider and other sea ducks, but one may not eat of river ducks on Friday, for they are viands. There are more ways than one of whipping the devil around the stump. Of eggs, however, there was no question, and my companion was an ardent collector of egg shells. With a drill he carefully bored a hole in one side of the egg into which a small blowpipe was inserted; now this blow-pipe was connected with a rubber bulb, which, on compression by the hand, forced out through the same hole the contents of the egg. These contents were not wasted, - far from it, - but were received into the frying-pan, and we had, with a clear conscience and as the result of scientific activity on our parts, omelets of eiders', great-black-backed gulls', puffins' and even cormorants' eggs. The last named we let Mathias prepare after a Labrador receipt: flour in generous proportion was mixed with the eggs, 


\section{CRUISE OF LA BELLE MARGUERITE}

together with salt and butter, the whole forming a stiff pancake which was browned on one side, turned over and browned on the other, and then cut into four pie-shaped pieces that could stand alone. It tasted good, although a trifle fishy, but it had great staying qualities, in fact, as I noted in my journal, it was " fine and filling."

That afternoon we did not sail far, for even in Labrador it is calm sometimes, and we cast anchor in the Grand Bay of Piashte-bai, the nomenclature which I follow with great care is at times difficult. Here we were surrounded by granitic glacier-smoothed islands, cut by dark basaltic dykes, supporting but little vegetation and that of an arctic type, - a bleak coast. On one of these islands we found the remains of a white man's camp as shown by a circle of empty tins, and discovered the cause of his presence in some blasting operations which had been conducted for the purpose of obtaining a small quantity and poor quality of mica. The quest for "wealth in the rocks" proves often a disastrous will-o'-the-wisp for mankind.

We visited another cormorant colony the 


\section{A LABRADOR SPRING}

next day, undeterred by our first experience, and found seventy-three nests on the bare rock, after which we bore away for the high headland of Quatachoo, which stood up like a sentinel among the multitude of low, prostrate islands where we took refuge from the stormy sea in a deep and quiet anchorage. The water was tinged the colour of tea from the river which poured with the roar of distant rapids from the mainland to the north. From a rocky hill, which rose about a hundred and twentyfive feet nearly sheer from the ocean, I could see between the scuds of fog that drifted landwards the low island-studded coast, barren for the most part, save for the trees in the gullies. The red and gray granitic rocks were relieved by great veins of white quartz, and cleft by dark basalt, while every deep hollow contained a snowdrift of unsullied whiteness, and all the seaward shores were surf-fringed.

"The Night-winds sigh, the breakers roar, And shrieks the wild sea-mew."

It was cold, it was barren, it was lonely, for there was no sign of man to be seen in any direction, yet it was a scene thoroughly to be enjoyed. 


\section{CRUISE OF LA BELLE MARGUERITE}

There is a charm about the barren places of the earth not easily described in words, a charm that the artist attempts to transfer to canvas, and one that appeals often times with especial force to the naturalist.

After an excellent dinner of broiled duck in the salle à manger of "La Belle," for I must not have the gentle reader imagine that I lived only on air and view and philosophy, we turned our prow again to the eastward, and sought through the stormy sea for the place the canards des roches, the curious many. coloured harlequin ducks, were said to frequent, a place known in these parts as Watcheeshoo. On peering over some rocks here we saw three of these curious birds and watched them swim and fly away.

While I was toasting my toes on the little Io $x$ I 6 inch stove at the entrance of the cuddy that night, listening to the cooing of the eiders, the gentle chiding laughter of the saddle-backs, and to the roar of the surf on the outer side of the island, - while within was calm and peaceful, - watching the sun go down in a.golden glory, and thinking of our luck in seeing the harlequins, a canoe silently glided alongside. 


\section{A LABRADOR SPRING}

Kneeling in the bottom at the paddles were two Indians, one an old man with a scanty beard, the other a beardless youth. They came on board and shook hands, exchanged a few unintelligible words with our men and departed as silently as they came.

The Indians that I saw in canoes on the coast always kneeled and did not sit up on the thwarts as their white brothers often do. At Mingan one Indian refused to take me in his canoe unless I sat in the bottom and did not paddle. To escape that ignominy I kneeled at the bow paddle in the canoe of another Indian, but when I could bear the position no longer, and my knees were almost paralyzed, I made bold to raise myself to a sitting position on a basket and continued to paddle. My friend, who was sitting facing the Indian in the stern, said that his countenance expressed the utmost anxiety at this move on my part, and that drops of perspiration stood out on his brow. And I do not blame him, for he did not know, and I could not tell him whether I had ever been in a canoe before or not, and he probably was unable to swim.

That evening Martial told us of his trip on 120 


\section{CRUISE OF LA BELLE MARGUERITE}

the ice a hundred and fifty miles up the Romaine River one winter, hunting and dragging stores on a sled for men who were measuring and charting that great stream. His clever pantomime made his patois more intelligible, and every now and then he would favour us with snatches of song. He was a merry fellow. The songs of Mathias were slower and more solemn, and I often wondered whether they were not some of the old songs brought by the Acadians from France in 1605 . His family name is among the list of those expelled from the basin of Minas in I755.

Sunday, May zoth, was a cloudy, rainy day with a cold northeast wind, and, under reefed sails, we threaded the narrow passages among the islands in a manner that showed a wonderful knowledge of this region by our men. The charts we brought with us they never looked at, and indeed these charts showed but a small part of these islands and of the intricacies of the coast. Up Yellow Bay, a long, narrow land-locked passage, we sailed with apparently no chance of escape, but suddenly we opened up what on the eastern coast would be called a "tickle," and through this we glided to the open sea. 


\section{A LABRADOR SPRING}

As we passed Pashasheeboo Bay, a name which Mathias delighted to roll on his tongue, we saw a solitary house, a lobster fisherman's. For a long distance we sailed among rocky islands, and we passed a lovely protected harbour, forest skirted, which Mathias called le hâvre des sauvages, for, he said, fourteen or fifteen families of Indians camped there every summer, and I admired their taste.

Soon the scene changed, and we skirted at a safe distance a ten mile, surf-lined beach, backed by cliffs and a dark spruce forest. The $\mathrm{Na}$ besippi River flowed out in the middle of this beach, and, at the eastern end, the Agwanus River discharged. Here was a big church, a bigger trading-house and a dozen or two small houses of the habitants, all fishermen and trappers. Hundreds of terns or sea swallows, as they are called, graceful creatures, flew about us screaming, and it was evident that they were nesting on the barren islands. As the breakers appeared to form a continuous white line across the entrance to the harbour where a ,few fishing boats were riding, at anchor, we concluded that the open sea was much pleasanter, and we pushed on in our staunch boat. 


\section{CRUISE OF LA BELLE MARGUERITE}

Two or three more miles of sand beach and then rocky islands uncounted appeared as we sailed by Washtawooka Bay. The land was everywhere terraced and flat topped, showing stages of elevation above the sea, the edges of the terraces marked with lines of snow which made good settings to the fringes of spruces. It was a glorious day's sail of over fifty miles in the storm and wet, but our boat was staunch, our crew were skilful, our oilskins tight, and the air and the water contained many objects dear to the ornithologist.

We reached Natashquan, literally " the place where the seals haul out," at the end of the afternoon, and cast anchor in the shallow, sandy harbour at the mouth of the little Natashquan, after running on to a sandbar. Mathias, while rowing us ashore in the canoe, after failing to make us understand in his native tongue, astonished us by an attempt in English. "Sirs," he said, for he afterwards told us he had learned English at Clark City, "the tide she rise low, maintenant."

We were hospitably received by Martial's sister, who asked us, as I thought, whether we wished crabs, for breakfast next day. I 


\section{A LABRADOR SPRING}

eagerly acquiesced, having visions of broiled crabs, but there appeared on the table large pan-cakes much soaked in fat, crêpes, a favourite dish along the coast, and one we found stood us in good stead on an all day tramp. There was, however, no crape, as my friend suggested there might be, on the door next day.

Natashquan is a rambling village on both sides of the mouth of the Little Natashquan River. On the right bank was a small group of houses including the trading post, which went under the name of the Labrador Fur Company, and as the wife of the trader had just entertained eight Indians at dinner she was much wearied, yet on learning that we came from the States and talked English, she herself came from Chicago, - she and her husband made us at home, and gave us with the aid of a piano and her pleasant voice a musical evening.

Another building on the right bank was the house of the telegraph operator, he of the wig and a face devoid of eyebrows, lashes and beard. The trader told us that some years ago this man and another strongly opposed the appointment of a certain schoolmaster by the 


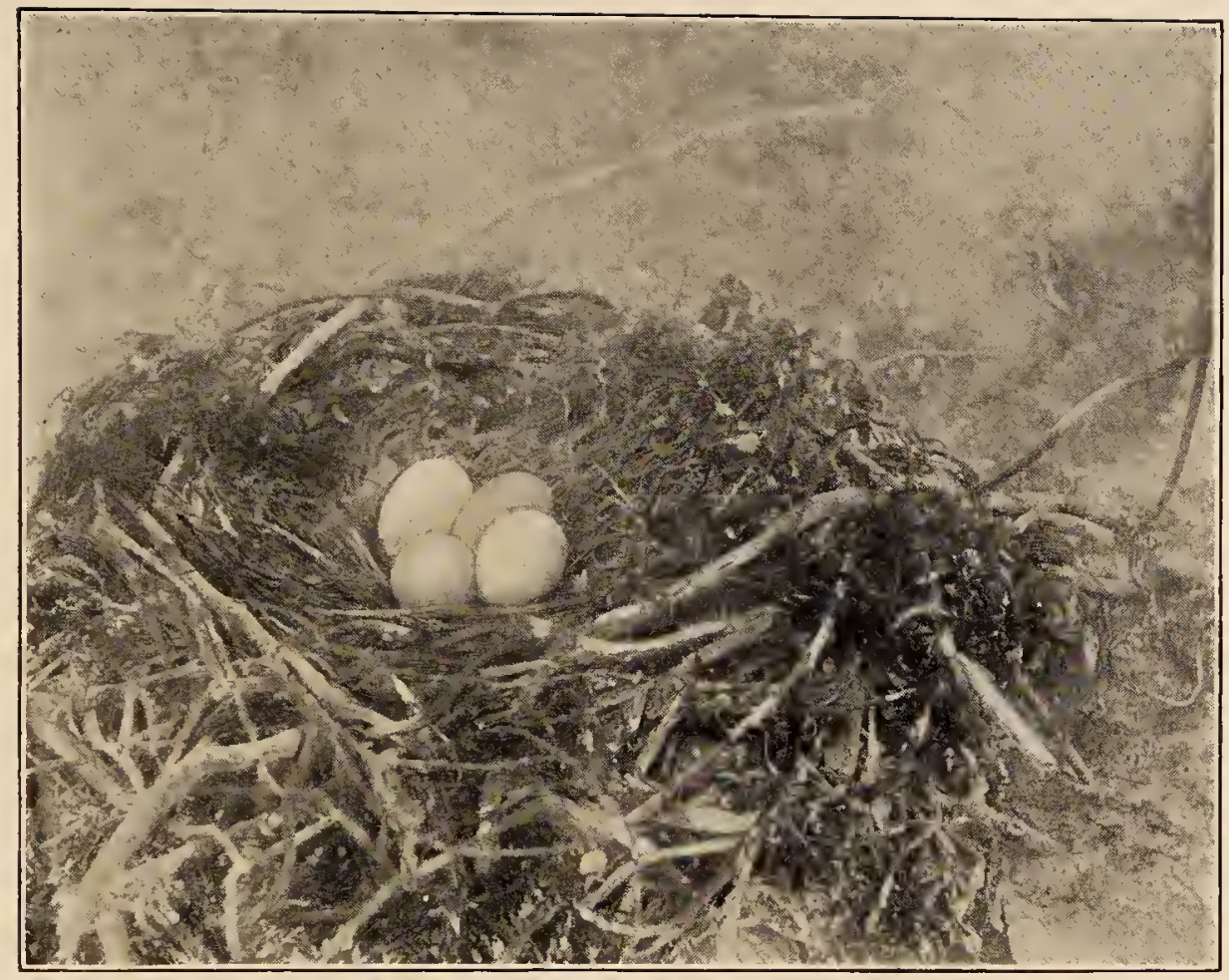

NEST AND EGGS OF DOUBLE-CRESTED CORMORANT.

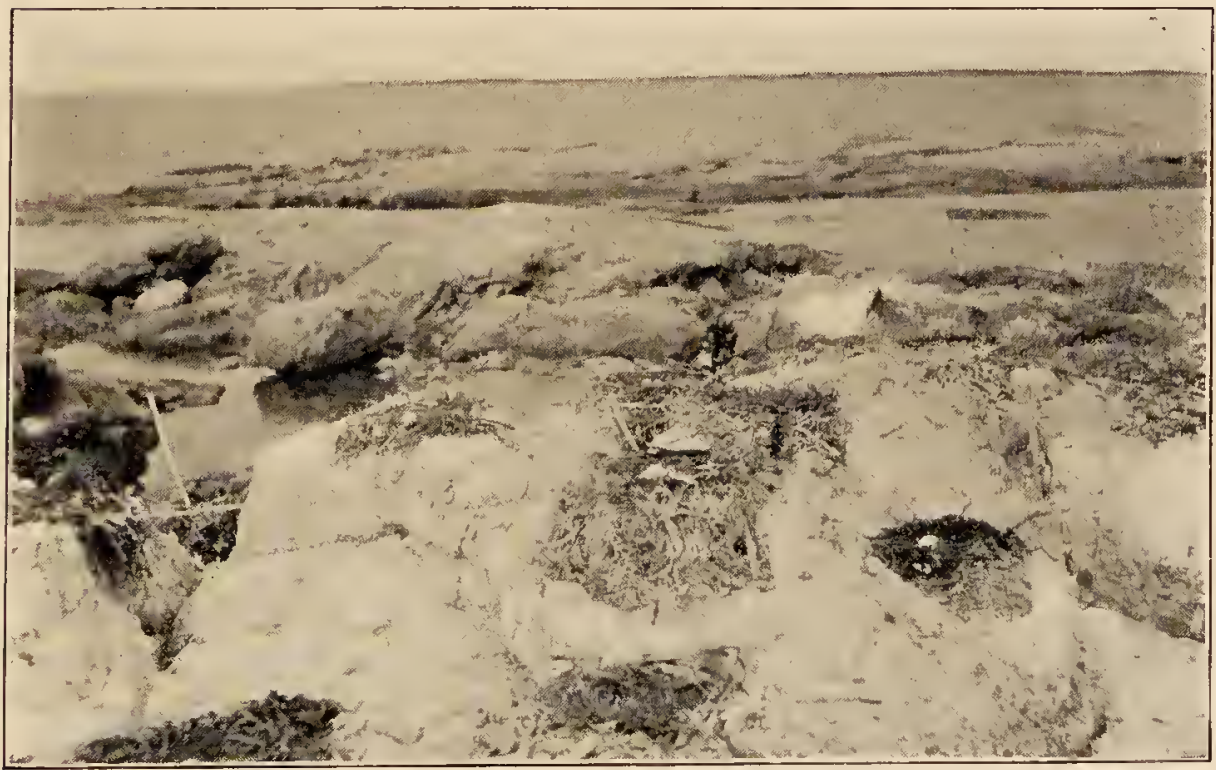

A CORNER OF A CORMORANT ROOKERY AT SEAL ROCK. 



\section{CRUISE OF LA BELLE MARGUERITE}

priest, and in the heat of the argument, they exclaimed "may we lose every hair of our bodies if this vile one is appointed." The priest had his way, and they both began to lose their hair. One in fright and repentance made his peace with the priest, and all was well. Not so the stubborn telegraph operator, and to this day he is as devoid of hair as is an apple.

On the eastern side of the river, which we crossed in one of the numerous small boats left on its sandy shores, were a few more houses and a large church and a priests' house. From the latter a straight path led along the top of a ridge, - an old raised sea beach, - bordered on either side with thickly growing white spruces. Beyond lay the beach four miles long, backed by shifting sand dunes, and at the end of the beach was the Great Natashquan River with its little Indian village.

It was on this beach that we saw a pair of piping plovers, with their sweet mournful calls, a bird that has not been recorded for Labrador before, and a splendid Caspian tern flew by so close that we could surely identify it. Audubon had found this bird here in 1833 and Frazer in 1884 had discovered a breeding 


\section{A LABRADOR SPRING}

colony. We were glad to find that the bird still survived.

Near the town the spruces and firs had been so cut away that the sand was sweeping back and had already overwhelmed one house. A large cross, evidently erected to stop the progress of the shifting dunes, stood in the midst of this waste. Heretic that I was, I could not help thinking it would have been wiser to plant beach-grass and trees.

As we had been told at Quebec that the mail boat reaching Natashquan about the first of June would continue on to Harrington, we climbed aboard the "Aranmore" as she lay at anchor at a long and safe distance off Natashquan, fully expecting to go on further east. What was our surprise when our old friend Captain Hearn turned her prow westward again, and my hopes of glimpses of the bird colonies of Cape Whittle and of Dr. Grenfell's hospital at Harrington were dashed. However, we were glad to return to Esquimaux Point, and I knew by previous experience that a Labrador steamer, like life itself, was very uncertain.

As unfavourable winds had prevented us 


\section{CRUISE OF LA BELLE MARGUERITE}

from reaching Bald Island near Betchewun on this cruise, we visited it on the 8 th and 9 th of June by sailing from Esquimaux Point in "La Belle Marguerite." The island is of about a dozen acres in extent, and presents to the sea turreted and arched limestone cliffs from fifteen to thirty feet high. Its flat top was covered with deep black soil, on which a forest of giant stalks of cow parsnip were still standing from the previous summer. In this loose soil and under the rocks were numerous burrows of puffins, or perroquets, as they are universally called on the Labrador coast. Each burrow was from two to three feet long, and, at the end, the owner was usually sitting on her single dirty white egg in a nest of straw.

Extraordinary birds are these puffins, about I 50 of whom were to be constantly seen flying and swimming about the island. Their large parrot-like red bill, their pale gray spectacled face and black collar, and their short, chunky build made them appear grotesque on the water or in flight, and even more grotesque when they stood bolt upright on the rocks, and comically anxious when they walked about near us. Their bills in the breeding season, when examined 


\section{A LABRADOR SPRING}

carefully, are seen to be scarlet, with a steel blue base on the lower mandible, a white line on the upper and an orange patch at the commisure. There is a curious blue horny spur above the eye, and the edges of the eyelid are vermilion, while the inside of the mouth is a deep gamboge yellow, and the feet are orange red.

Another bird that later in the season laid its eggs on this island, one can not say nested, for the egg is deposited on the bare rock, was the razor-billed auk, and we saw a little company of seventeen of these birds flying about the island, all that was left of the throngs that bred in that region in Audubon's day. Here the bill is jet black ornamented with a curved white line, and wonderfully set off, when the bird opens its mouth, by the brilliant yellow lining of that cavity. The birds were swimming about in little bands with their tails cocked up, and were evidently discussing matrimonial plans.

One does not expect to pick up the eggs of wood birds at sea, but on our return from Bald Island we were obliged to anchor behind Little St. Charles Island, where a fishing boat from Esquimaux Point had also taken refuge from 128 


\section{CRUISE OF LA BELLE MARGUERITE}

the high wind. An exchange of shouted civilities between the two boats resulted, in which it appeared, - for our fame had spread, that some eggs of the spruce partridge, greatly desired by my companion, had just been found. In fact the fisherman while ashore for wood had put his foot into the nest, and broken four of the twelve eggs. However, the remainder, beautifully speckled with brown, were gratefully received.

I have now finished a cursory survey of the Labrador coast from its western point to $\mathrm{Na}$ tashquan, a distance of 250 miles. In another book I attempted to describe the 600 miles of coast between Bradore and Nain. The hiatus of about 240 miles between Natashquan and Bradore was explored and described by Audubon in I 833 , and I hope some day to follow in his steps; in the meantime it is a satisfaction to feel that the gap in one's narrative is so well filled. 


\section{CHAPTER VI}

\section{THREE MODERN CARTWRIGHTS}

\section{"In such like Toils and Sports, the Year goes round, And for each day, some Work or Pleasure's found."}

- Cartwright.

T the latter part of the eighteenth cen1 tury an adventurous Englishman spent sixteen years on the bleak eastern Labrador coast engaged in fishing, trapping and hunting, and in trading with the aborigines. Captain Cartwright's Journal, originally published in I793, shows the evident joy of the man in his rugged life on those shores, and his appreciation of its attractions, notwithstanding the severity of its climate and its loneliness. Although, as a younger son in an old family of depleted fortunes, his ostensible object was the accumulation of money, it is evident that the spirit of sport and adventure, and not the desire to amass a fortune, was his guiding star. Originally possessed of independence of character, 130 


\section{THREE MODERN CARTWRIGHTS}

his life in Labrador further developed it, as such a life naturally would, and instead of leading the trivial humdrum life of the average sporting squire, which would probably have been his lot if he had settled down at home, he became a careful observer and an accurate recorder of animal and vegetable nature, a skilful leader of men, and just in all his relations with them, notably so in his relations with the savages, both Eskimo and Indian, - an interesting figure indeed in the early days of the Labrador coast.

This same joy of living in remote parts, away from the conventional life of the cities, this same love of a wild life with all its hardships and struggles, is still an attribute of humanity not difficult to find. The conventional city life has been of very recent advent in the history of the human race; it is a mere speck in his inheritance of the past, and we all tend to revert to the savage. The man who does not is sincerely to be pitied; he does not know the full joy of living.

Three friends that I made on this Labrador coast each suggested in his own way my old friend Cartwright. The first was a New Eng- 


\section{A LABRADOR SPRING}

lander from a poky little suburb of a great city, a clear-eyed, well-bronzed, rosy-cheeked man, spare and sinewy. He had spent fourteen years on this coast and he loved the life, and so did his wife, who joined with him in trapping and shooting. They lived in a comfortable house in a lovely bay protected by a fringe of pointed firs and higher land on the north, and by an outlying island on the south. A spring of clear cold water bubbled forth summer and winter on the little beach in front of the house. They had no neighbours but the white-throated sparrows and hermit thrushes in summer, the ptarmigan and snow buntings in winter, for the nearest settlement was eighteen miles away, but they did not lack for occupation and diversion, and they had much of interest to show and talk about when they hospitably received us at their table. Of birds, as always when we met intelligent people, we talked much, and our host showed us some stuffed birds, his own handiwork, including an albino murre, and, of live birds, a pair of black ducks he had brought up as pets. Of trapping he had many tales to tell, both of his successes and failures. He had that day returned from setting some 132 


\section{THREE MODERN CARTWRIGHTS}

great bear-traps, for in the spring when the bears first come out from their winter hibernation, their fur is in good condition.

Of the common belief, so frequently enlarged upon by writers of popular natural history, that animals frequently bite off their own legs to free themselves from traps, he had no regard. In fact, although he said the animal sometimes eats the severed and dead foot under the trap, he had found no evidence of their biting the flesh or bone above the trap. By twisting and pulling, however, in their attempts to get away, he said the animal not infrequently escapes and leaves the foot behind. In the case of the rabbit this freeing from the trap by the loss of a foot is not uncommon, an accident that the slender bones and tender skin of this animal would easily account for, while the usual explanation, in an animal accustomed to use its teeth on bark and other vegetable substances only, he deemed very improbable. Although I had never considered the subject before, and had accepted the usual explanation, I believe he is right, for the method of escape from a trap by biting off the foot would be a most unnatural procedure, and would call for a considerable 


\section{A LABRADOR SPRING}

amount of reasoning power, while the struggle ending in breaking away would be the natural and instinctive one.

Of shooting seals with a rifle he had much to tell us, and of the pleasures of this pursuit conducted by lying down covered with a sack on a reef, and acting and grunting hoarsely like the animal; and he showed us some beautiful skins both of the bay seal and of the horse-head. Between the tenth of June and the tenth of July he catches seals in nets, and one hundred and eighty pelts were the result of his work the year before.

Of his dogs he spoke with great affection, and they - massive brutes, some Eskimo, some half Newfoundland - fully reciprocated it. To one who is familiar with the cruel way in which many of the Eskimo dogs are treated on the eastern Labrador coast, it was a pleasure to see the different treatment accorded them here. Unfortunately an epidemic among the dogs had spread like wild-fire along the coast the winter before, and many of the most valued animals were dead, some within the space of a day after the first seizure.

My New England Cartwright had much to 134 


\section{THREE MODERN CARTWRIGHTS}

say of the intelligence and strength of some of these, and of the pleasure of speeding over the icy highways that line the coast in winter behind a team of these useful animals. The winter season, instead of shutting him up to wait impatiently for milder weather, was a season of great interest and pleasure, the trapping season and the season for much travelling. In summer his means of transportation was a staunch little schooner, about the size of our "Belle Marguerite," to which he had just applied a fresh coat of paint, and had got ready for the launching. The life of this former New Englander was a varied and interesting one, and I could not help comparing it with the life he would have led if he had remained in the suburb of the great city.

Of the second figure in this company of three I speak with particular admiration and respect. $\mathrm{He}$ is a Belgian who has lived here for thirteen years and married a Labradorian; both he and his charming wife and sister-in-law received us with great courtesy and hospitality. $\mathrm{He}$ is an interesting and picturesque figure, a man in many respects lile Cartwright, although superficially very different, and belonging to 


\section{A LABRADOR SPRING}

a different nation. At the head of a little bay close by the discharge of a tumultuous river on a granitic glacier-smoothed rock he has built his house, - the finest house I have seen on all the Labrador coast. The roar of the rapids beside him, and the subdued murmur of the distant cataract in the forest, is always in his ears. On the one side the sun rises over the bay with its rocky islets, and sets on the other behind the barren hills which terminate his view over the dark spruce forest. On the shore of the bay below him are the half dozen houses of the habitants, and a tiny chapel completes the picture of the little village, while several fishing boats ride at anchor a stone's throw away.

On the opposite side of the river are some large enclosures that at once attracted our attention. These are parks for the breeding of black foxes, whose skins, beautiful in themselves, have been greatly enhanced in value by the whims of royal fashion until they have become one of the most precious products of the Labrador coast. To the trapper in the wilds they are lucky incidents, a much hoped for dream which may never be realized. To 


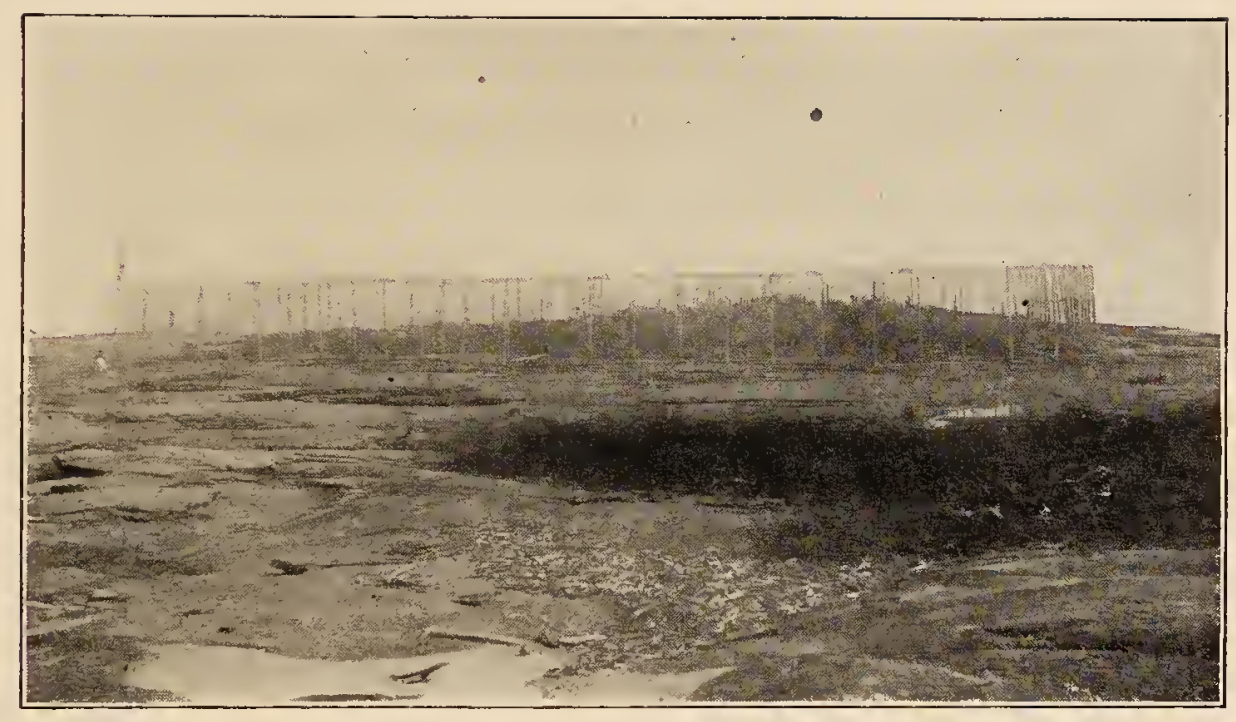

A BLACK FOX PARK AT PIASHTE-BAI.

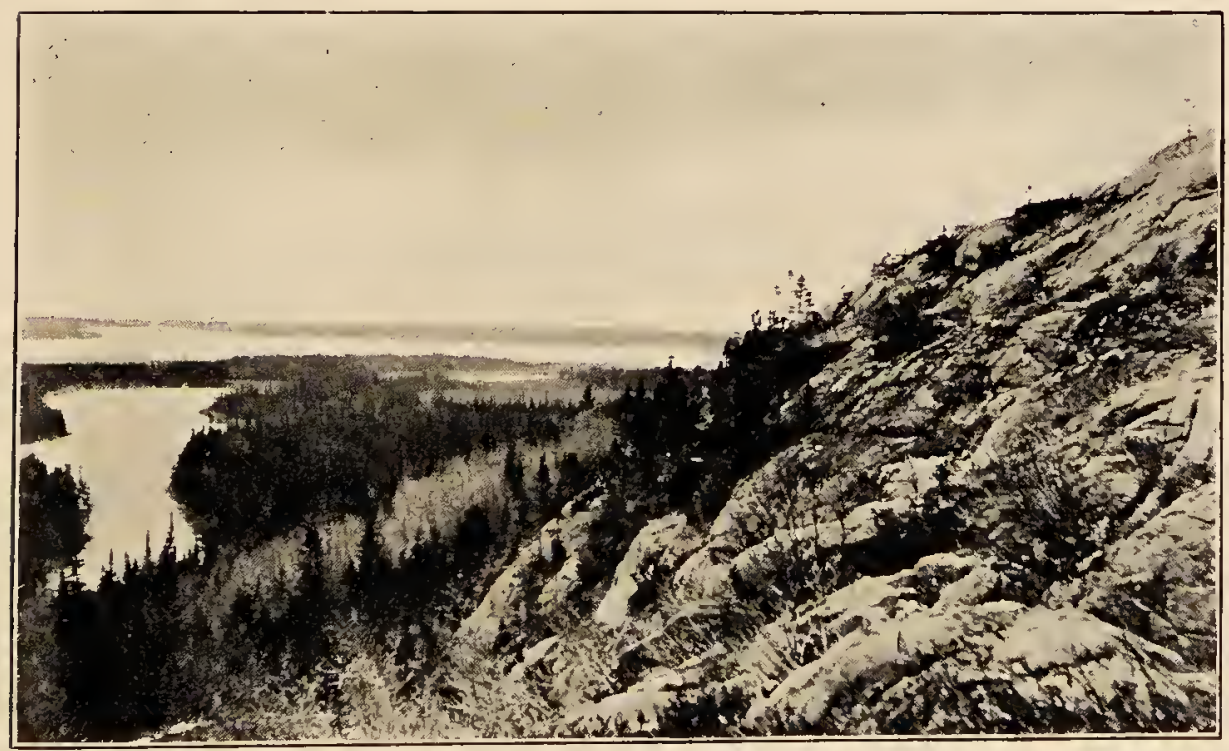

PIASHTE-BAI RIVER AND LAKE FROM THE BEGINNING OF THE HIGH LAND OF THE INTERIOR. 



\section{THREE MODERN CARTWRIGHTS}

produce these in captivity has been one of the many schemes of the active brain of this Belgian Cartwright, and he has devoted many years to the study of the subject. He has five or six parks each of an acre and a half in extent, surrounded by strong wire netting fences, supported by posts eighteen feet tall. An overhang at the top prevents the escape of the active inhabitants above, while the solid Laurentian rock is an effectual bar below. Each park contains but one family, and they have plenty of room to roam, and plenty of place for concealment among the stunted spruces. They live well, for lobsters are especially procured for their table. I caught a glimpse of one splendid fellow running about with his thousand dollar coat. We were told that these skins are of more value than those of wild ones, for the animals are well looked after and their food supply never fails them. It is not, as with Indians and wild foxes, a short feast and a long famine. In July they bring forth their litters of five to nine each, and breed true.

The black fox is merely a colour-phase of the common red fox, and not a separate species. 


\section{A LABRADOR SPRING}

The red fox varies from the common form, which is a rich fulvous red with a white tip to the tail and small black markings on feet and ears, through certain well marked stages, known as the cross or patch fox, and the silver, to the black fox. In the cross fox the feet, legs and under parts are black, while red more or less mixed and overlaying black extends over the head and back. In the silver fox the red is nearly absent, and the fur is dark at the base, while the tips of the hairs are white or gray. In the pure black fox the white or silver tips to the hairs are everywhere eliminated, except at the tip of the tail, which always remains white. The red phase is of course the most abundant form, while the others increase in rarity in the order given. The black is the rarest, and a good black fox skin brings an extremely high price. The Fur Trade Review for I907 says: "The fashion for this article continues, and the fine dark skins are specially in demand - the highest priced skin realized $£ 440 "$ (\$2, I 40). Our Belgian friend told us he had obtained from $\$ 400$ to $\$ \mathrm{I}, 400$ for his skins, and averaged $\$ 700$. After five or six years he had succeeded in eliminating all the red from 


\section{THREE MODERN CARTWRIGHTS}

their furs, and the animals were now breeding true and producing only the black phase.

The United States Department of Agriculture has recently published a farmer's bulletin on the subject of silver fox farming, by Wilfred $\mathrm{H}$. Osgood. It concludes that fox farming should never be attempted south of the southern boundary of the Canadian zone, and it states by way of summary that: "Like most new enterprises, fox raising is a business regarding which opinions vary. The favourable facts are that silver foxes are easily and securely kept in simple wire enclosures; that suitable food for them is cheap and easily obtainable; that they are not subject to serious diseases, and that their disposition and the colour of their fur can be improved by selective breeding. Opposed to these are the unfavourable facts that they are by nature suspicious, nervous, and not inclined to repose confidence in man; and that, largely for these reasons, they do not breed regularly and successfully, except when cared for by experienced persons more or less gifted in handling them.

"The number of persons now engaged in the business is relatively small, and the work is 


\section{A LABRADOR SPRING}

still experimental, yet many of the initial difficulties have already been overcome. Numerous minor failures seem explainable in large measure, and are offset by several conspicuous successes. It is therefore probable that under proper management fox raising will be developed into a profitable industry, and it is perhaps not too much to expect that a domestic breed of foxes will be produced. Only time will show how such expectations will be realized, but present indications must be regarded as very encouraging."

The house of this Belgian Cartwright did not remind one of Labrador, although many of the trophies displayed on its walls were products of the country. The rooms were large and comfortable, with ample doors and windows. One room suggested an armoury, as it contained racks of guns of all sizes and patterns, from the newest hammerless breech loaders to the oldtime muzzle loader with an elongated barrel. The window-sills of the billiard-room were lined with flowering plants, and the walls contained many products of the chase, - boars' heads from Europe and caribou antlers, seal skins and bear skins from the neighbourhood. A 


\section{THREE MODERN CARTWRIGHTS}

walrus skull and an Eskimo harpoon from the northeastern coast hung near some cabinets of mounted birds, the product of his gun along the coast. Among these we found a blue jay, a bird hitherto unrecorded for Labrador. This bird he had shot the previous winter not far from his house; later we saw a single bird of this species at Mingan, so that our record for this bird for Labrador is very satisfactory.

One of the most interesting departments of the household was the refrigerating plant, built after the master's own design. It consisted of a detached building in which were several zinc-lined chests surrounded by a freezing mixture of snow and salt. In these chests, frozen solidly, was game of all sorts, mostly obtained in winter for summer use. Trout and porcupines, haunch of caribou and of beaver and of other animals, for our host, like Cartwright of old, being of independent mind and not subservient to custom, was fond of trying the flesh of animals not commonly used as food. Among the birds were willow ptarmigan, white as snow, with the exception of their black tails and the black centres of their wing quills, and a couple of splendid Barrow's golden-eye ducks. 


\section{A LABRADOR SPRING}

These were at once courteously given us for our collections.

Of the man himself it is almost unnecessary to speak; the environment which he created is sufficient to describe him. Ardently devoted to the chase, a good shot, interested in natural history, a clever artist, a quick and accurate observer, he afforded us many delightful hours spent in his company, for we were so fortunate as to meet him not only as guests at his house, but at several other places on the coast where he had gone to meet Indians to trade for their furs and incidentally to fish and to shoot. His observations on birds, for one who had not made an especial study of the subject, were particularly acute and interesting, and he entered with ardour at our suggestion upon a more careful and scientific study of ornithology. Like Cartwright he had kept a journal of his daily life and observations.

Like his prototype Cartwright, also, he was interesting in figure and in dress. Picture to yourself a rather small man with pointed beard and moustaches, piercing black eyes lighted up with kindliness and vivacity, and a lithe frame showing great vigour and activity. In 


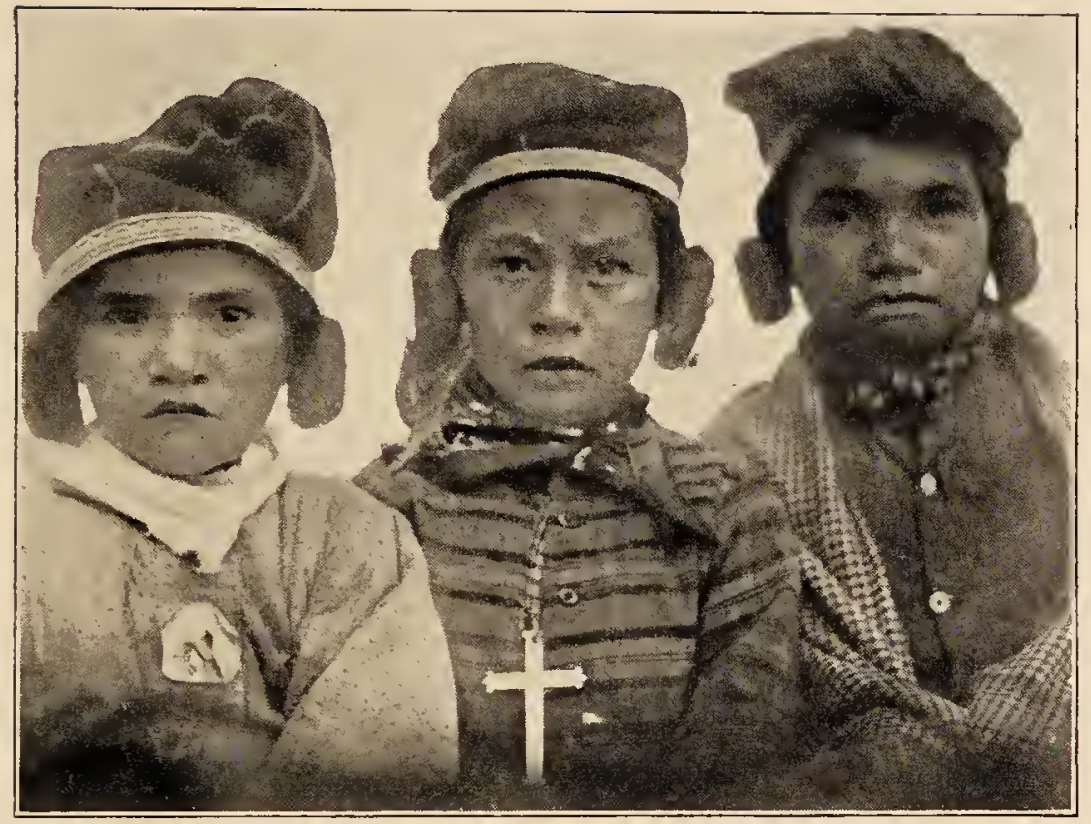

THREE LITTLE INDIAN GIRLS.

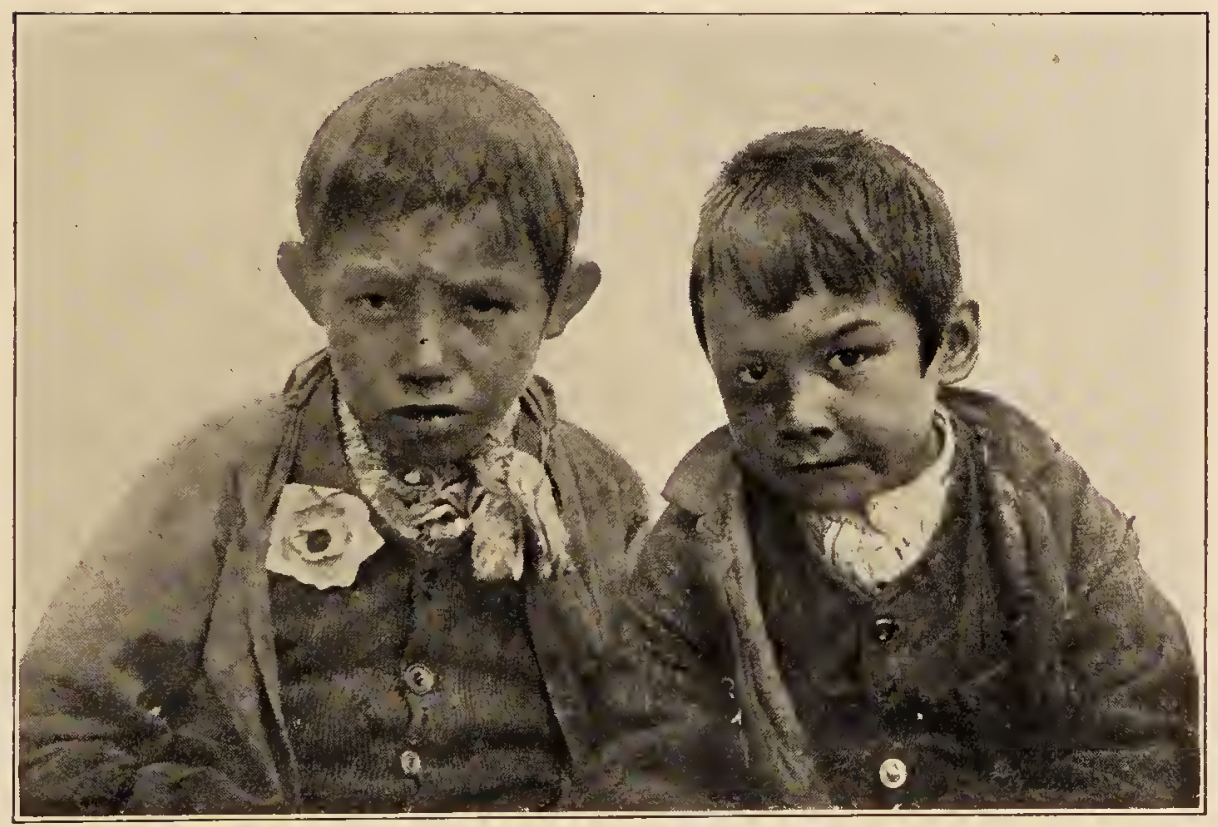

TWO MONTAGNAIS COMPANIONS AT MINGAN. 



\section{THREE MODERN CARTWRIGHTS}

the field he wore a dark green corduroy suit of knickerbockers, and a tall pointed cap made of otters' tails. His gun hung from his shoulder suspended by a strap. A photograph of him I saw in the house of one of his numerous friends on the coast shows him in winter dress. $\mathrm{He}$ is on snow-shoes, and is clad entirely in white with the exception of his dark seal-skin boots and of the embroidery on the cuffs of his mittens. His dark eyes, moustaches and beard contrast well with the white pointed hood which terminates, Eskimo-like, the upper part of the costume. A gun is held over his left shoulder, and a fine black fox, as in the old print of Cartwright, is slung under his right; the handle of a hunter's axe appears behind.

A man is often damned by his neighbours and acquaintances, but everywhere we went on the coast, people of all sorts spoke well of our Belgian Cartwright. They all recognized his capabilities and his constant courtesy. Some spoke of his great accuracy of aim with shotgun or rifle, others of his eccentricity in sitting down to a dinner of fox or some other unheard of meat, and others again of his skill in billiards. The story goes that when fishermen or 


\section{A LABRADOR SPRING}

trappers visit him who have never before met with such a piece of civilization as a billiard table, he has innocently amused himself by showing them grotesque ways of playing, using the butt end of the cue or pushing it with both hands as gravely as if it were the approved method, but, however he plays, he is easily a match for half a dozen of them.

I am sure we shall never forget him nor the dinner at his house. After several days' cruising in "La Belle Marguerite" we landed at his little bay, and paid our respects to him. Our credentials as scientific bird students obtained from the department of Colonization, Mines and Fisheries of Quebec served here as elsewhere to introduce us, and we were soon deep in a laboured conversation on the subject of the birds of Labrador. Laboured the conversation certainly was on our parts, for, as our host spoke only French, we were obliged to resort at times to our guide, companion and friend - a pocket conversational dictionary.

As we beheld ourselves for the first time for many days in the mirror of the dressing-room where our host left us to prepare for dinner, our hearts failed us, and I left my friend con- 


\section{THREE MODERN CARTWRIGHTS}

templating his ragged hunting suit and two weeks' beard in dismay, while I courageously descended to the salon in my a little less ragged khakies. Our host wore green corduroy knickerbockers, silk stockings and pumps, the ladies were becomingly attired in delicate white material of Parisian and not Labrador make, when my friend sailed into the room with great dignity in his flannel shirt sleeves and ancient "fluffy" leather waistcoat. He confessed to me afterwards that the anguish of deciding between a shrunken, stained and torn shooting jacket on the one hand and shirt sleeves on the other was intense, but the "fluffy" leather waistcoat turned the scale in favour of the latter unpardonable costume. However, we endeavoured to make up for the poverty of our clothes by the elegance of our conversation, and we drank the health of the madame and la belle soeur in the red wine of sunny France with carefully chosen phrases from our little dictionary. I could not help thinking of the tramps in Erminie. A five course dinner with all the "frills" on the Labrador coast was certainly a surprise.

The third in this triumvirate of men of 145 


\section{A LABRADOR SPRING}

original ideas presented an entirely different figure from the last. A tall, raw-boned Yankee, a painter by trade, and at first sight an uninteresting personality. As we came to know the man more intimately, however, and as he revealed to us his history, his plans and his views of life, we could not but admire and be attracted by him. Although in appearance, voice and conversation he was a typical Yankee, - he "hailed from" Western Massachusetts, his name was evidently French. His ancestors, it appeared, had come from France and settled at Quebec, where they prospered. His great grandfather, visiting the mother country, left his affairs in the hands of the priests to guard and preserve. He died abroad and his son and grandson, - the latter the father of our hero, - failed to claim their patrimony from the Church, but moved to a little village in New England where our Yankee Cartwright grew up to the humble trade of house-painter. It was evident, however, that the adventurous and independent blood of his ancestors coursed through his veins, and he refused to remain in his native town, but travelled from place to place plying his trade, but fretting all the time 


\section{THREE MODERN CARTWRIGHTS}

at the bondage of the trade-unions. Finally the spirit moved him to visit in a brief vacation the home of his ancestors in Quebec, and while there he stumbled on the mail steamer about to leave for the Labrador Coast. He took passage, intending to return by the same boat, but at Seven Islands he kindly offered to help out for a few days in painting the church, taking the place of a painter who had fallen ill. This was three years ago and he has been the ecclesiastical painter along the coast ever since, kept there partly by the entreaties of the priests, but chiefly, he admitted, by his enjoyment of the independence of the life, and the fact that he was his own master and not subject to walking delegates. He could work over time to his heart's content, and do his very best without fear of disparaging another. $\mathrm{He}$ was particularly enthusiastic about the healthfulness of the climate, and, like Cartwright of old, declared that, although the thermometer went many degrees below zero in the winter, he never felt chilly as at home.

His plans for the future were certainly original and were all carefully arranged. A1though he thoroughly enjoyed his work and the 


\section{A LABRADOR SPRING}

free hand he had in it, he had decided that a year from that summer he would join forces with some good Indian friends of his, and go with them into the interior on their regular hunting and trapping expeditions, not to emerge until the following June. In this way he expected to satisfy his love for adventure and wild life, and to lay in a stock of furs with which to astonish his New England friends.

My modern Cartwrights are all good men and true. 


\section{CHAPTER VII \\ THE MONTAGNAIS INDIANS \\ "Oh, for a lodge in some vast wilderness."}

- Cowper.

THE Labrador peninsula is a region well adapted for fur-bearing animals. Along the edges on the eastern and southern coasts the white settler has long since well-nigh exterminated or driven off these animals with the notable exception of the crafty fox, but the interior still serves as a habitation and fairly safe refuge for many beasts, although their numbers are considerably diminished owing to extensive fires ${ }^{x}$ that have swept the country, and to constant persecution. Most of the interior is unexplored by the white man, yet his influence through powder and ball supplied

${ }^{1}$ According to Hind immense forest fires occurred in Labrador in $1785,1814,1857$ and 1859 , and a very extensive one I was told by Mr. J. A. Wilson, the factor at Mingan, occurred about 40 years ago. 


\section{A LABRADOR SPRING}

to the Indians, and his eagerness for trade has had its effect on the native animals.

Hind has penetrated into the interior about one hundred and fifty miles by way of the Moisie River. Cabot has explored from the eastern coast to the valley of the George River, while Mrs. Leonidas Hubbard, and following closely in her steps, Dillon Wallace, have travelled up the valley of the Nascaupee from the Northwest River, crossed Lake Michikamau and the height of land and descended the George River to Ungava Bay.

But the explorer who has traversed Labrador far more than all of these, and one who has added most to our accurate knowledge of the interior, is the Canadian geologist, A. P. Low. He has done his work quietly and unheralded, and the results are buried among the other documents of the Canadian Geological Survey. To tell of all his doings would be long, but among other things he has crossed Labrador in a canoe from south to north by way of Lake Mistassini, the East Main, Kaniapiskau and Koksoak Rivers. He has also ascended the Hamilton River, portaged by the Grand Falls, - grand indeed, for they descend 760 feet in 


\section{THE MONTAGNAIS INDIANS}

twelve miles and fall 302 feet sheer, - and explored Lake Michikamau. From the Hamilton River he ascended the Attikonak, and, by way of the Romaine and the St. John Rivers, descended to the Gulf of St. Lawrence.

Yet after all the greater part of this interior of Labrador is a vast wilderness, still unspoiled by the whites, still a happy hunting-ground for the Indians. The Eskimos, true sea-dogs that they are, keep to the sea-coast, except in the far north beyond the Kolssoak River. Of the Indians there are two main tribes in Labrador, divisions of the Cree branch of the great Algonquin family. North of the Hamilton River dwell the Nascaupees, while south of this grand natural boundary the Montagnais or Mountaineers have their migratory homes. Besides these is the small tribe of coastal Indians of Hudson Bay.

Originally dwelling further to the west these Algonquins were gradually driven east and north during the 16 th and $\mathrm{I} 7$ th centuries by the terrible Iroquois, whose name even now strikes terror to their hearts and serves as a bogey to frighten their children. The Iroquois 


\section{A LABRADOR SPRING}

were said to have pursued them at one time as far as the Natashquan River. With the Eskimos, whom the Indians always hated and despised and with whom they do not intermarry, they were formerly always at war. While the Eskimos in the time of Jacques Cartier inhabited the whole of the eastern and even some of the southern coast, probably as far west as the Eskimo River, they are now not found south of Hamilton Inlet, or Esquimaux Bay as it was formerly called. Even as late as the time of Cartwright, in the latter part of the I8th century, the Eskimos came as far south as the region about the Straits of Belle Isle. Armed with guns procured from the French, the Indians, although terrified by the Iroquois, were able to strike terror in turn into the hearts of the Eskimos who fell back before their onslaughts and deserted this southern region. Battle Harbour is said to have received its name from one of the last battles fought by these two aboriginal races. This could hardly have been the case, however, for Cartwright mentions the name Battle Harbour in his Journal, although he does not allude to any fight there between the two races, 


\section{THE MONTAGNAIS INDIANS}

and Eskimos at that time dwelt as far south as Cape Charles.

One beautiful day the last of May when "La Belle Marguerite" was anchored in a sheltered little cove among Les Isles des Corneilles, I was delighted by a cry from Mathias of "Les sauvages!" - a cry which, in the earlier history of French-speaking America, has times innumerable struck terror into the heart of the white man. Not so in this case, for les sauvages here are no longer savage, they are but a peaceful remnant of their old selves, and, being well treated by the white man, treat him well in return, as indeed they have always done when dealt with in this unusual manner. Two barges like our own had sailed into a neighbouring cove, and, through the glass, I could see a motley crowd of men, women, children and dogs tumbling into canoes and going ashore. They soon were grouped about a fire and were evidently cooking and eating their breakfast, which, judging from the shells seen later, consisted of roasted eiders' eggs. A brilliant patch of colour they made on the barren hillside, that contrasted well with the gray of the lichen-covered rocks, the green of the firs, and 


\section{A LABRADOR SPRING}

the white of the snowbanks. On visiting them I found a camp well on the way to completion. Each was doing his or her part, - chiefly hers. The women were gathering balsam boughs and thatching them into thick springy beds for their wigwams, which were to be erected in flat places from which they had first scratched away the moss. A man and woman were busily engaged in scraping the hair from a seal skin, keeping it wet in a pot of water placed between them, - the first stage in the manufacture of skin-boots. Children and dogs were everywhere, and while the former showed timidity and even terror, the latter showed belligerency at my approach. The terror displayed by the little Indian children at the sight of a stranger was as marked as was the fearlessness and placidity on the part of the infantin-arms under the same circumstances.

There seemed to be four families, five men and five or six women young and old, seven or eight girls and boys of all ages, and an infant, not to mention numerous Indian dogs and a cat.

My communications with them were interesting to me, but not very satisfactory, as I 


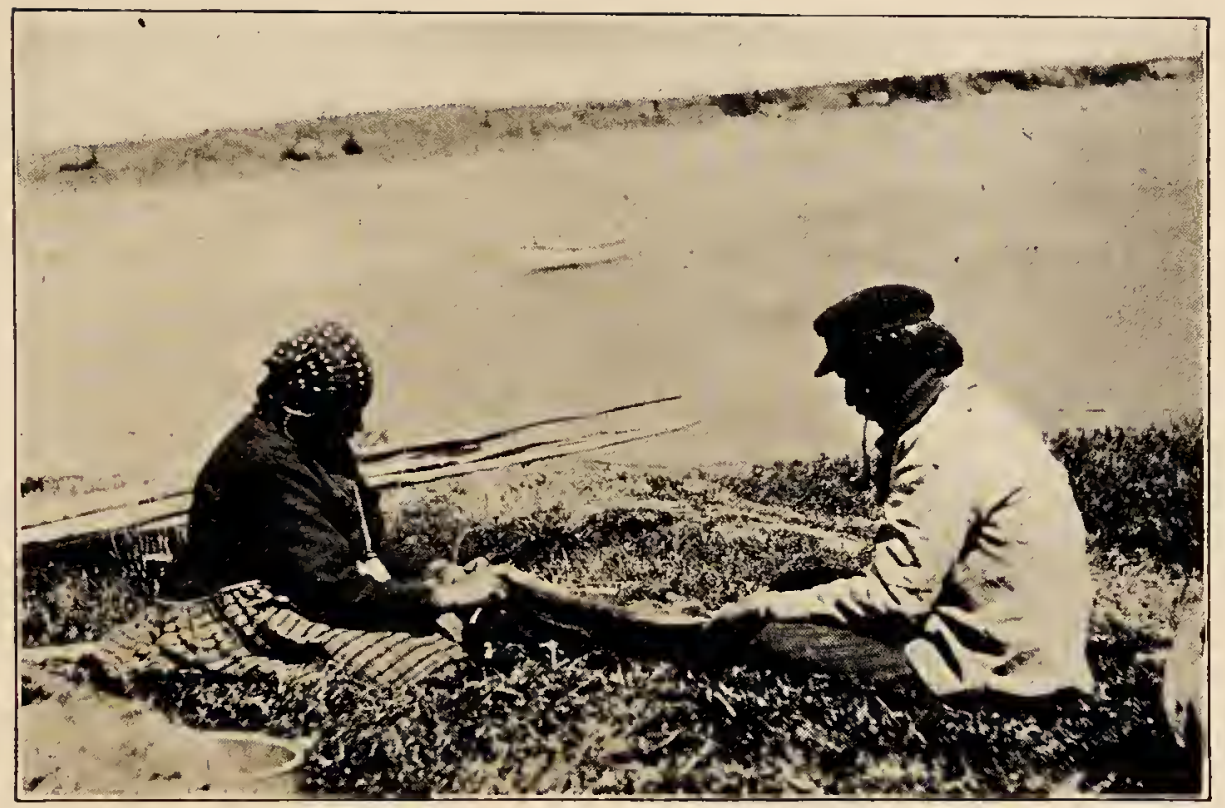

INDIANS SHAVING SEAL SKIN AT THE ISLES DES CORNEILLES.

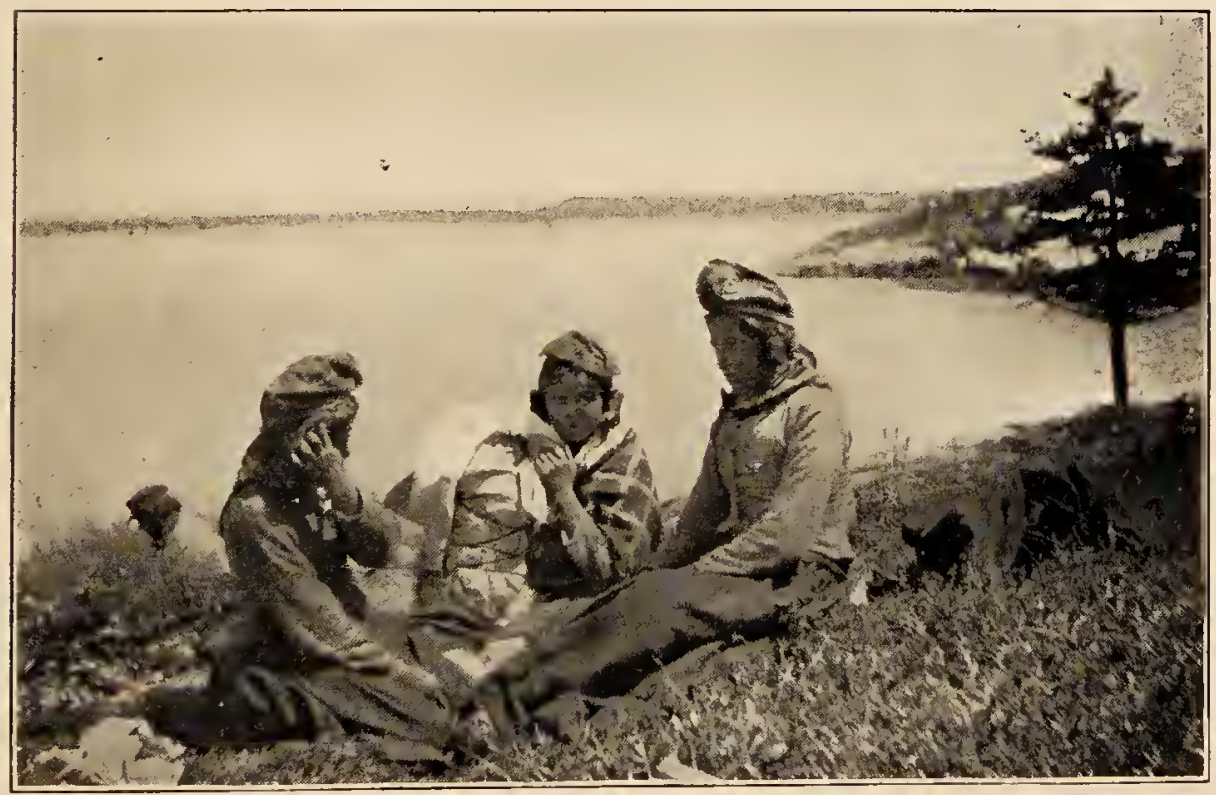

THE PAPOOSE. 



\section{THE MONTAGNAIS INDIANS}

could not understand their language, nor they mine, with one exception in the case of an elderly man, who from time to time ejaculated a few words of French, and who appeared to understand some of my broken sentences in the same language. However, all were pleasant and jolly, and there was considerable laughter, probably at my expense, a laughter in which I joined as I wished to appear sociable and was unable to express myself in any other way.

The faces of these people were dark olive brown in colour, and glistened in the sun as if they had been oiled, - as I suspect was indeed the case with some; their noses were aquiline; their eyes were black and rather narrow and in some set aslant as in the Mongolian type. A few showed signs of admixture with the white race.

While the men wore their straight black hair rather long about the neck, the women and girls had theirs tied up in tight oblong knots or rolls wound with black cloth in front of the ears, forming a conspicuous and characteristic mark of their sex, absent only in very young children. The women and girls all wore pic- 


\section{A LABRADOR SPRING}

turesque caps of red and dark blue broadcloth in alternate stripes in shape like a liberty cap. The bands of these caps were ornamented in bead-work which seemed to increase in extent with the increasing years of the wearer. The men's head gear was a more prosaic black cloth cap with a visor. Both sexes wore either long seal skin boots with the hair shaved off, or, as was usually the case, low caribou skin moccasins, more or less ornamented, and thick woollen stockings, of bright primitive colours, red, green, white, blue and purple, in stripes. These stockings in the case of the men, were pulled up to the knees over the trousers, which were the ordinary cylindrical affairs of civilization, weathered from black or brown, to a good neutral tint. A rough cloth jacket or one of dirty white canvas completed the costume in the men, which was given a touch of colour by a red or blue handkerchief tied about the neck and shoulders.

The women wore stout woollen skirts, generally of dark plaid, their costume completed above by a bodice of red or plaid, fitting snugly about their powerful waists and shoulders, and by a coloured handkerchief that was knotted 156 


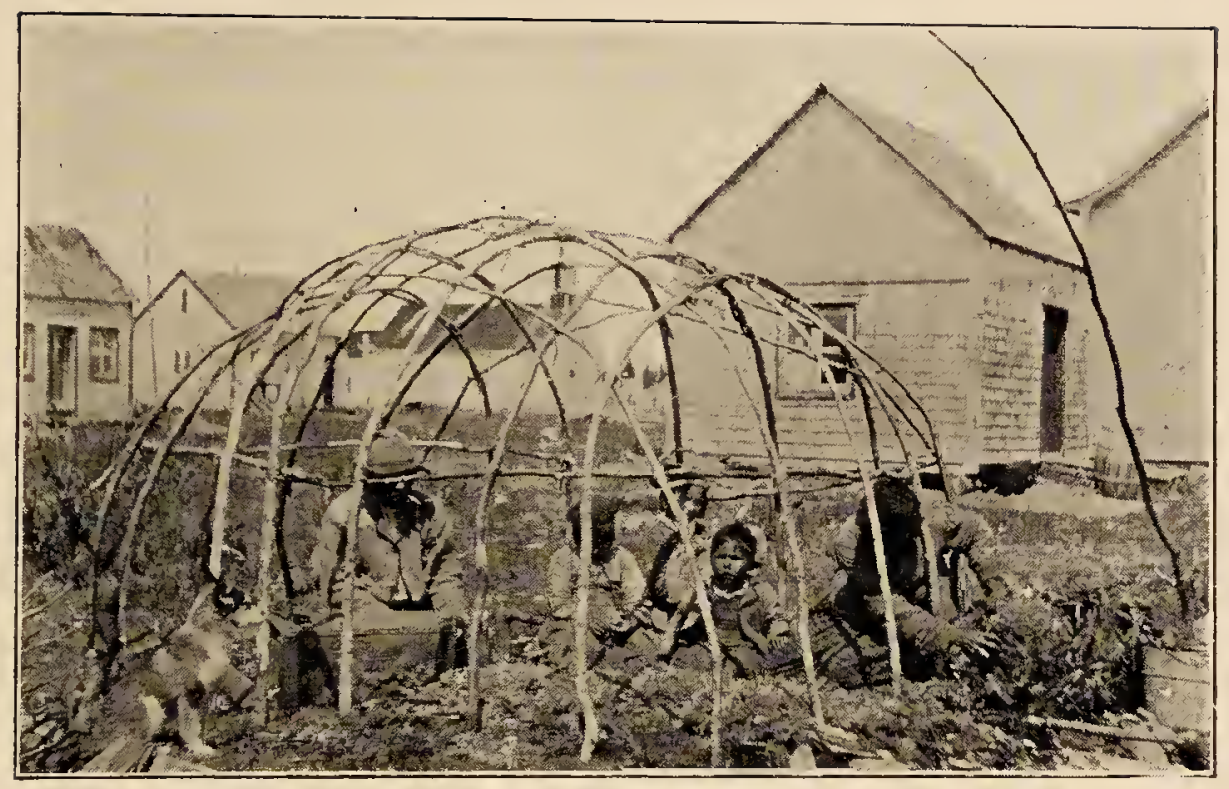

WIGWAM IN PROCESS OF CONSTRUCTION AT MINGAN.

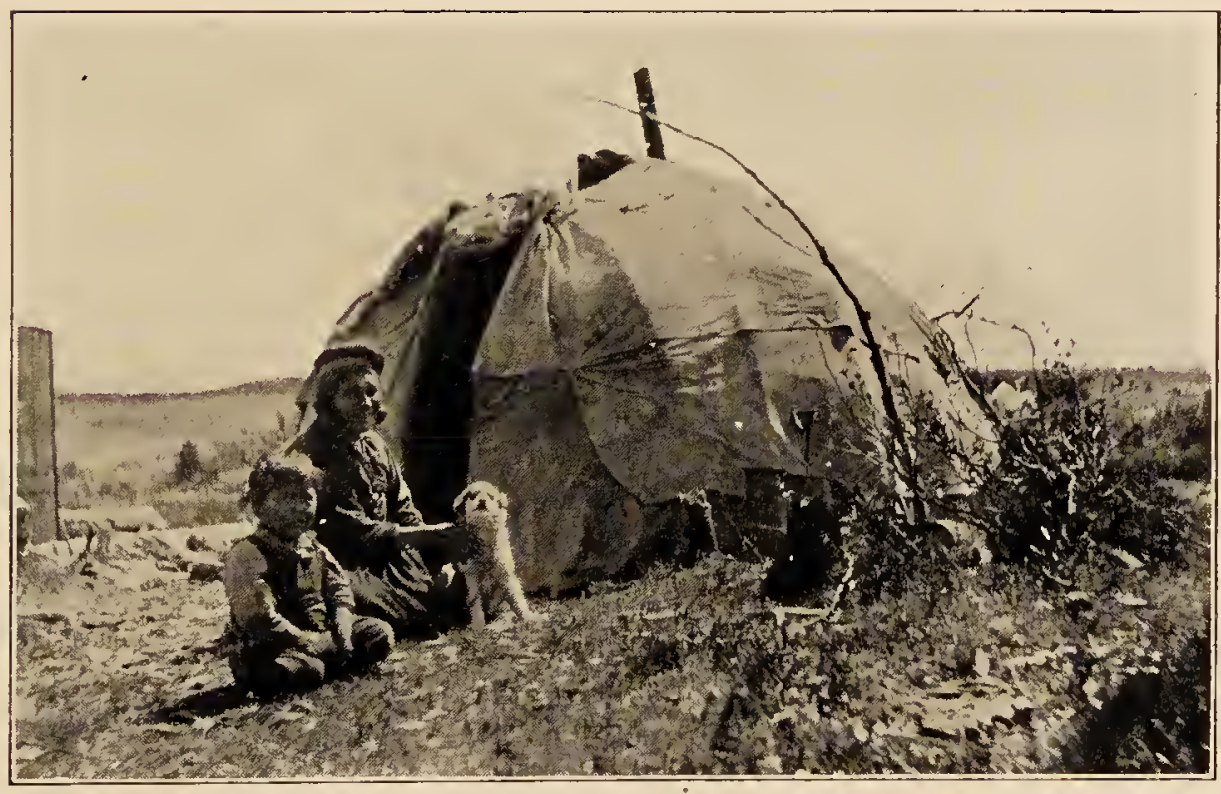

COMPIETED WIGWAM. 



\section{THE MONTAGNAIS INDIANS}

or folded about the neck. The infant was bound up as all proper Indian papooses are, with a criss-cross of lacings over an abundance of wrappings, the whole forming a bundle that could as easily be handled, and that made as little fuss as a small bag of flour.

The common posture taken by these Indians was a kneeling one, with the body resting on the heels as shown in several of the photographs, a position very difficult to maintain for any length of time by a white man. This is the same posture commonly assumed by the Japanese as shown in the familiar pictures of these people grouped about tea-trays. According to Professor Okakura Yoshisaburo of Tokio, the Japanese and Koreans alone of Asiatic peoples habitually adopt this posture, while the Chinese sit as do the Europeans.

The wigwams of this people that I saw at various places along the coast were of three sorts: the ordinary cotton wall-tent of the white man, the wigwam made of straight slender poles set in a circle and leaning in to the centre, and the lodge of birch sticks stuck in the ground in a circle or oval, and bent so as to form a low rounded or oval structure, 


\section{A LABRADOR SPRING}

strengthened by split birch saplings interwoven at right angles. These last two forms of dwelling were covered with canvas, - I saw none covered with skins or birch bark. Nearly all contained small oblong sheet-iron stoves with tiny stove-pipes that emerged between the sticks at the top of the wigwam. Much of their cooking seemed to be done at fires outside, where a large pot was to be seen hanging from a wooden bar between two poles.

These friends of mine, these "savages" at the Isles of the Crow, were not mercenary, they had nothing to sell, but having completed the labours of the year in the interior in trapping for furs, and having sold the products to the traders, they were, like ladies and gentlemen, travelling about visiting their friends and spending their summer's vacation at the sea-side. Later they would attend religious services.

That they were making disastrous inroads on the sea-birds, and contributing to their extermination, there was no doubt, but it must be remembered that before the arrival of the whites, when the Indians were in larger numbers along this coast, the sea-birds easily held their 


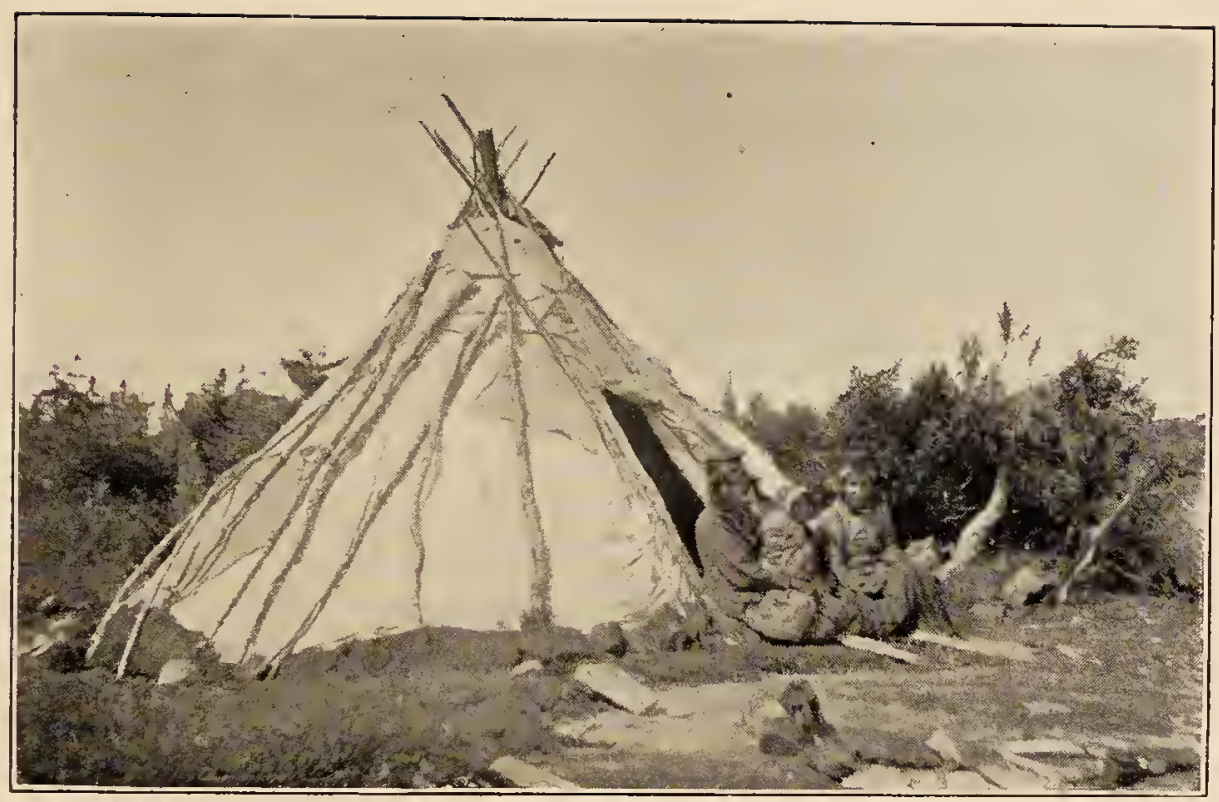

WIGWAM AND INDIAN FAMILY AT PIASHTE-BAI.

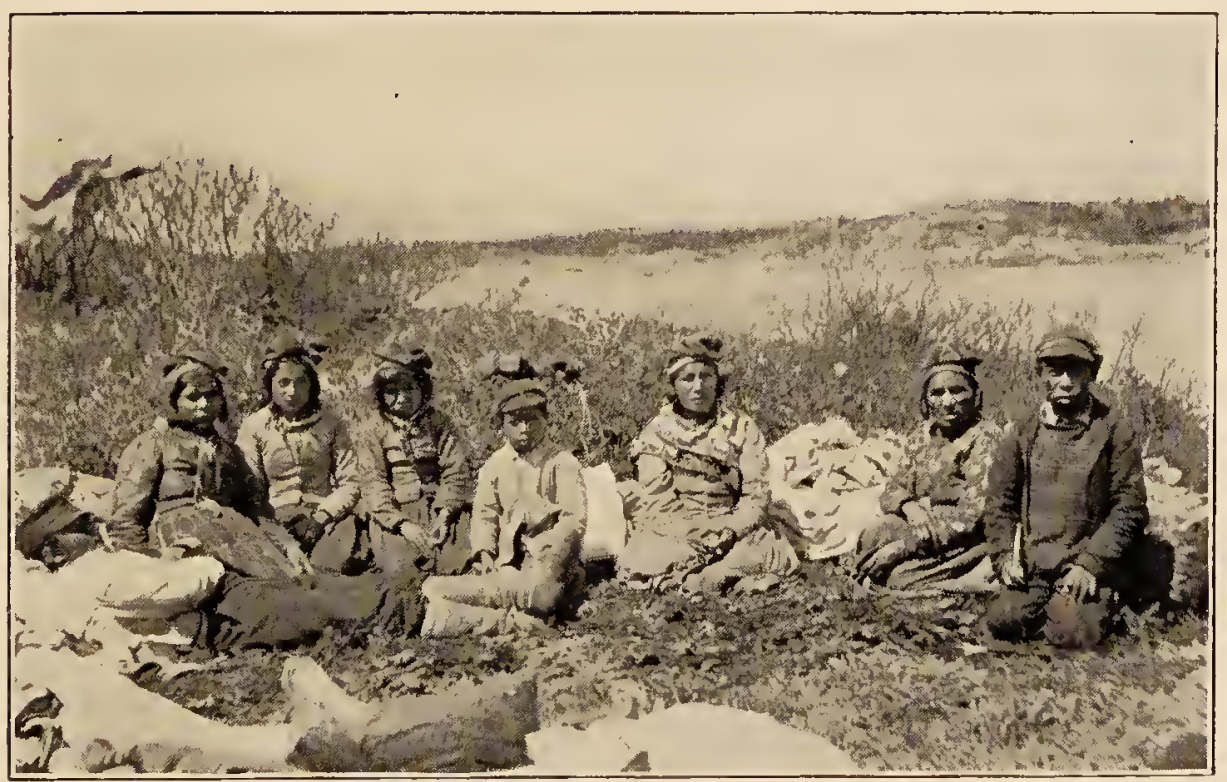

INDIANS AT THE ISLES DES CORNEILLES. 



\section{THE MONTAGNAIS INDIANS}

own. The moderate and natural pruning of the savages did no appreciable harm. It is the white man that has brought the birds so low by systematic egging, and, although the eggs are not exported in schooners to Halifax now as in Audubon's day, a continuous robbery of the eggs by the fishermen is still kept up along the coast. And they can hardly be blamed, for eiders' eggs are easily found and make delicious eating. But, as I have said in another place, ${ }^{\mathrm{I}}$ it is a great pity that these men should be allowed to "kill the goose that lays the golden egg," and that they should not be taught like the Norwegians to protect the birds, and take in return for the trouble a moderate amount of down and eggs. This might be made an industry of immense and increasing value to the entire coast, for there is no region better adapted to the needs of the eider duck, but as long as the reckless methods now employed are continued, and as long as guns are so constantly in use in the nesting season, so long will this war of extermination go on until there are no birds left. Would that a Labrador St. Cuthbert might arise who would bless and tame ${ }^{1}$ Along the Labrador Coast, Bostnn, I904, pp. 263, 264. 


\section{A LABRADOR SPRING}

these eiders! The nesting birds, particularly the females, are easily shot, and at Piashte-bai I saw several of their carcasses spitted and being dried and smoked in front of an Indian wigwam.

We met with several similar camping parties of Indians, although we were rather too early in the season to find many such, but at Mingan and at the Natashquan River we saw large numbers of the Montagnais. At the latter place they have a small village of wooden houses on the right bank of the mouth of the Great Natashquan River some four miles from the white settlement at the Little Natashquan. Having spent the winter in the interior, hunting and trapping, they had arrived here in May, and it happened on May 3 Ist, the day we tramped over through the dunes and along the beach from Natashquan, that we arrived just as the Indians were embarking for Musquarro. This point, some fifteen miles farther down the coast, is an Indian mission, presided over by a Roman Catholic priest, who goes there once a year at this season for the purpose of celebrating the various rites of the church - feasts and fasts, baptisms, marriages and funeral services 


\section{THE MONTAGNAIS INDIANS}

- for the benefit and spiritual health of these Indians. Indeed the Musquarro missionary had come down on the steamer with us, - a tall, austere man, a typical robe noir. It was in I 660 that the Indians of Seven Islands requested the Jesuits at Tadousac to send them a robe noir, as they dared not go to Tadousac for fear of the Iroquois.

At Musquarro the Indians stay several weeks enjoying their religious life, for besides the sale of their furs, one of the chief objects of their visit to the coast is the attainment of a veneer of Christianity. With this veneer they return to the Natashquan River and ascend it in August for another winter's work in the interior, where, doubtless, some of the veneer wears off, and a little paganism crops out.

Cabot says: "Under the strict injunctions of the Gulf missionaries, the sound of the téuehigan, 'the ceremonial drum,' is not heard on the summer reserve, but once beyond hearing of the missions some remnant of the old rites is not far to seek. On the other hand, the church calendar is carried everywhere over the Montagnais country; each day a pin is moved forward and pinned through the paper 


\section{A LABRADOR SPRING}

at the succeeding date, and feast-days and Sundays are pretty well observed." r

The day was a dark and lowering one - this 3 Ist of May; low-lying clouds scudded across the sky, the sand-dunes were gray and forbidding, the river, over a mile wide here at the mouth, the colour of lead. Loons were driving north before the chilling blasts, in a continuous stream, two or three every few minutes, and a migrating band of tree swallows, with promise of summer, flew joyously about the great river, while on the bleak shore a picturesque scene was being enacted by the Indians, the bright colours of whose costumes relieved the sombre grayness of river and sky and shore.

They were all intent on their purpose, these savages of the Natashquan, and paid scant attention to us, as they hastened down over the sands to the shore of the river, carrying their packs and pots and babies, - men, women and children, dogs and even cats, all higgledypiggledy, and all in a great hurry to be off. There were perhaps eight or ten families in all, - men in the prime of life, with erect, wiry

${ }^{1}$ Labrador, by Wilfred T. Grenfell and others, New York, I909, pp. 224, 225. 


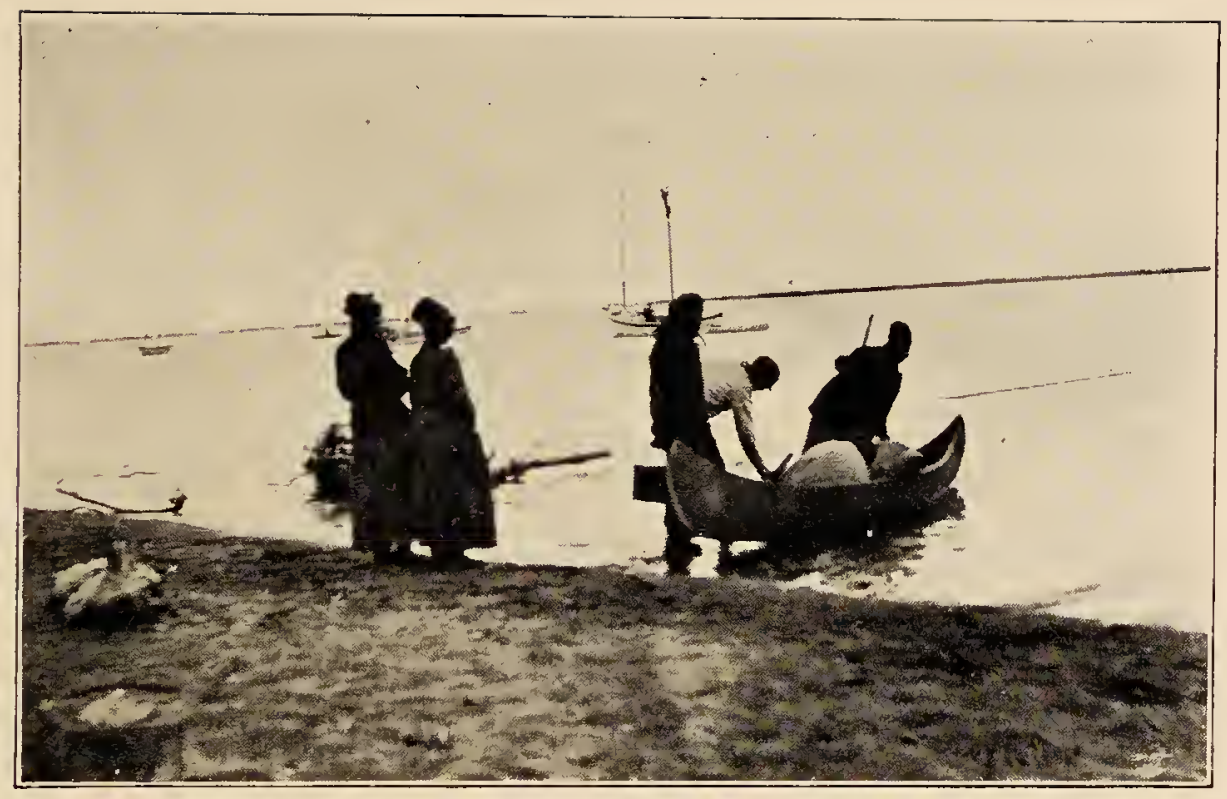

LOADING THE CANOE.

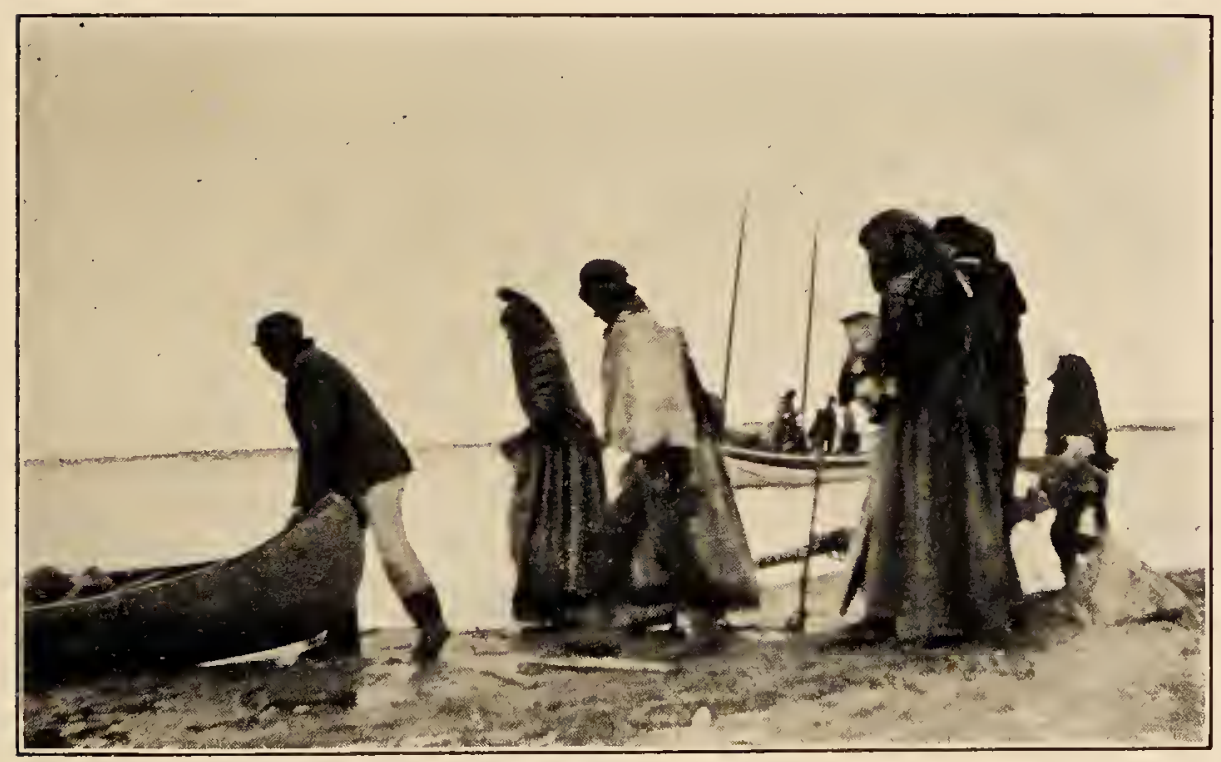

THE EMBARKATION OF THE MONTAGNAIS AT NATASHQUAN FOR MUSQUARRO 



\section{THE MONTAGNAIS INDIANS}

figures and bright, even handsome faces, most of them of medium height but some noticeably tall; old men with stragglng moustaches and beards, and shrunken but still erect figures; women of all ages, the old, wrinkled and haglike with dirty gray complexions, the young, clear-eyed and plump, their smooth, olivebrown skins tinged with rose on the cheeks, attractive to look upon; young boys and girls and stolid papooses. The small slinking foxlike Indian dog, black and tan in colour, was everywhere, each one nervously anxious not to be left behind. Every family possessed a cat, either carried in arms, or harnessed and straining at the leash, or again following free like a dog, anxious not to get its feet wet on the beach, but evidently still more anxious to go with the crowd in the canoes. We were told that the fashion of cats is a recent acquisition by these Mountaineers, and the cats were treated most kindly as pets, in marked contrast to the treatment of the dogs, who lead, indeed, a dog's life.

The costumes were like those of their relatives at Les Isles des Corneilles, but some of the old men wore long skirt-like coats, and had their heads bundled up in red handkerchiefs, or 


\section{A LABRADOR SPRING}

faded pieces of coloured cloth against the weather. One little boy of three or four years wore a long fur coat with skin side out, and a hood that dangled at his back. When I tried to photograph him he screamed with terror and hid behind his mother. Doubtless he thought me an Iroquois. A pitiable cripple, an aged child with shrunken body and twisted extremities, scurried prone like a hideous great spider over the sands, scaled the sides of a canoe and dropped into its depths.

Pipe-smoking was well nigh universal, and not confined to the men, nor to the adults. I shall always remember the picture made on the background of this bleak shore by a buxom young matron, with the usual coquettish rosettes of hair before her ears and her jaunty red and blue liberty cap, a tight fitting red woollen bodice, green plaid skirt, so short as to fully display stout legs clad in thick woollen stockings of red and white and in embroidered moccasins, striding over the sands, smoking a pipe, and bearing, as carelessly and as easily as if they had been of feather-weight, a lusty papoose in her arms and a large pack on her shoulders.

It was a busy and confusing scene, and one 


\section{THE MONTAGNAIS INDIANS}

felt anxious that a child or bundle or dog should not be left behind in the hurry of embarkation. Their canoes were drawn up along the beach, and into these they hastily threw their bundles and deposited themselves, while the dogs and children scrambled in as best they could. I counted two men, four women, two small children, a papoose, a dog and a cat in one canoe, - and the canoes were not large. The cat looked calmly over the gunwale at the alarmingly near-by water, the women smoked, chatted and laughed, while the men paddled skilfully but nonchalantly to the barge anchored in the stream. There were four of these barges, and they were soon well loaded, the sails hoisted, and away they went with the strong wind and the swift current. Some of the canoes were towed, others hauled up on deck, and a belated canoe containing two boys, a large pack and an anxious dog was picked up without disaster by the last barge as it sailed along. They were off for their religious feast of the year. In religious matters at least it is certainly a short feast and a long famine with these Indians. Migrations, whether of bird, beast or savage, are always interesting, and 


\section{A LABRADOR SPRING}

the annual migration of the Montagnais Indians is not the least so.

According to the annual report of the Department of Indian Affairs published in Ottawa in 1908, the number of Montagnais Indians for this strip of southern Labrador coast is 694 ; of these 76 come to the shore at Natashquan, 24I at Mingan and 377 at Seven Islands. The numbers given by Hind for 1857 were 100,500 and 300 respectively. With the exception of a very few who are too old or feeble to travel, all of these Indians spend the greater part of the year in the interior, making their annual migration to the coast in May or early in June when the ice goes out of the rivers, and returning in August. Those whose brief summer residence is at Seven Islands generally reach the interior by the St. Marguerite or by the Moisie River, while the Mingan contingent ascend the St. John River, and, by a series of smaller streams and lakes and many portages, cross to the Romaine, up which they travel into the interior. The Indians coming to the mouth of the Natashquan use that great river as a highway into the interior.

The early return of the Indians to the wilds 166 


\section{THE MONTAGNAIS INDIANS}

in August is partly in order to ascend the rivers before they are frozen, and partly to be in time for the annual migration of the caribou, but it is only in the north that this migration takes place on a large scale, and here the Nascaupees spear the animals in great numbers in the lakes and rivers. Rabbits, ptarmigan, spruce partridges, trout, ducks and geese help out the larders, but the Montagnais are becoming more and more dependent on the flour and other provisions that they obtain in barter for their furs at the Hudson's Bay Company's Posts.

Hind, quoting a former officer of the Hudson's Bay Company, says of the Montagnais: "Their country then abounded with the deer [caribou]. Porcupine were so numerous, that they used to find and kill (when travelling) a daily suffciency for their food without searching for them. Beaver were also plenty, and the white partridge [ptarmigan] seldom failed to visit our shores yearly, about the commencement of December, even from the heights of Hudson's Straits. While at present the deer are extremely scarce, porcupine almost wholly extinct, beaver very rarely to be got, and the white partridge is seen only every third and fourth 


\section{A LABRADOR SPRING}

year. Starvation was in those days unknown both to Montagnais and Nasquapees, but, these eighteen years past, some annually fall victims. At the time when the porcupine were so very numerous in the forest all over the country, and even in the woods lining the seashore, an Indian would then consider 50 pounds of flour a superfluous weight to carry with him to the woods where he intended to pass the winter, from his certainty of finding as many porcupines as he chose to kill, and other animals fit for food in proportion; but at present they have to carry in as much flour as they can, and those who penetrate far inland must carefully economize their provisions until such time as they reach the large lakes where fish are to be found. Another and very serious circumstance the Indian has to contend against, is the yearly decline of the furred animals to what they formerly have been. With all his labours, trapping and hunting, he seldom can pay his debt at the Company's posts, and most often only meets part of his expenses, which are yearly on the increase."

This decline in game is chiefly to be attributed to the extensive fires already mentioned, which 


\section{THE MONTAGNAIS INDIANS}

have destroyed the forest and soil alike, and partly to the excessive killing by fire-arms.

The chief occupation of the long season in the interior from August to May or June, besides the eternal search for food, is trapping of the fur-bearing animals, martens, beaver, lynx, fox, muskrat, mink and otter. In the pursuit of these and others of the family the Indians cover great distances, going at times not only as far as the Hamilton and Northwest River, the southern boundary of the hunting grounds of their cousins the Nascaupees, but even at times to the waters of the George River in Ungava. Occasionally, if they have had a bad season, and they are starving, a few come out for supplies in April, dragging their canoes over the ice or leaving them behind. Occasionally this early return to the coast takes place on account of their early success in obtaining a full supply of furs.

During the winter they live in the conical wigwams already described. In case of death the body is usually brought to the coast to be given Christian burial, and the little graveyard by the Indian church at Mingan is crowded with 


\section{A LABRADOR SPRING}

wooden crosses, on which are written or rudely carved the names of the dead.

At Mingan I had the best opportunity to observe these Indians as we spent a week there from the r 4 th to the 2 Ist of June, close to the Hudson's Bay Company's Post at the house of the old salmon-fisher of the place. The Indians had not all come out of the woods, but new families were arriving every day. The large kitchen of the salmon-fisher's house was an attractive place and was visited in the evening by fur traders, salmon-fishers from the mouth of the Mingan River, the clerks from the H. B. C. Post and Indians. The old salmonfisher himself was a picturesque figure, tall and strong, slim and wiry, but slightly bent with age; his beard was long and white, his eyes blue and kindly. His wife was a dark, black-eyed woman, bright and intelligent, and they had a large family of children of all ages, speaking French among themselves, Indian frequently, and English as occasion demanded. The kitchen was a long, low-studded room whose centre of attraction was a large iron stove always filled with glowing logs. Suspended from the middle of the ceiling above the stove were 


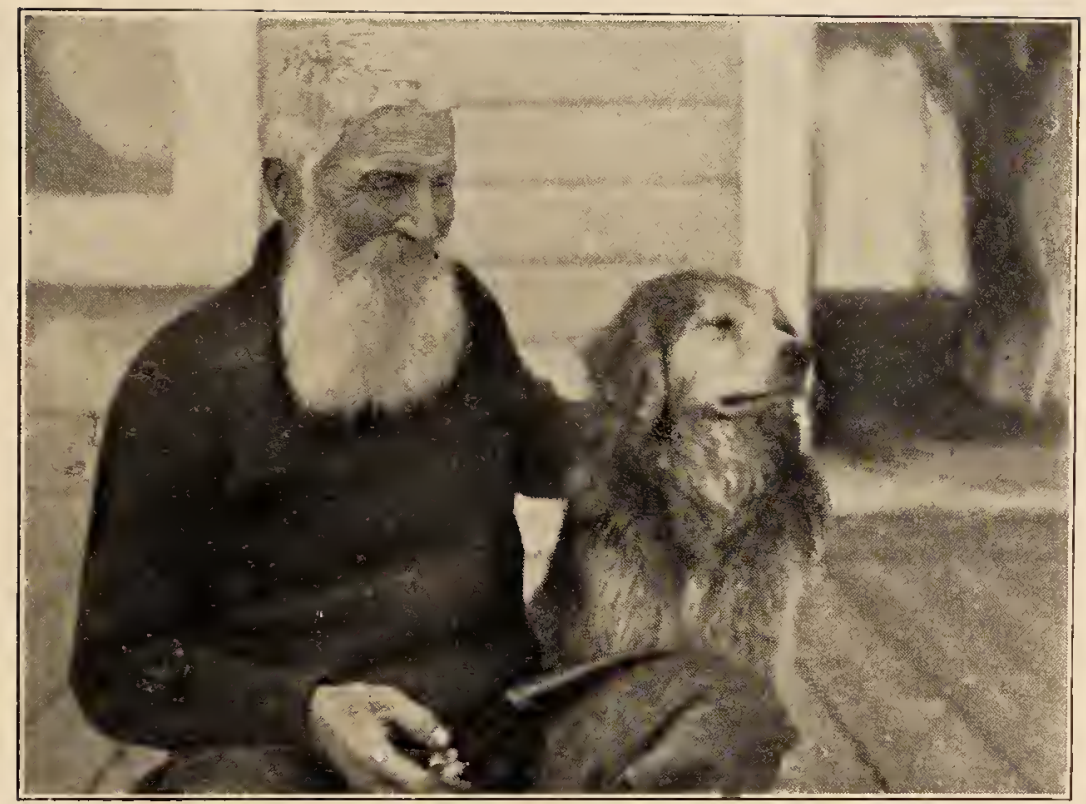

OUR HOST, THE SALMON-FISHER AT MINGAN, AND HIS OLD COMPANION.

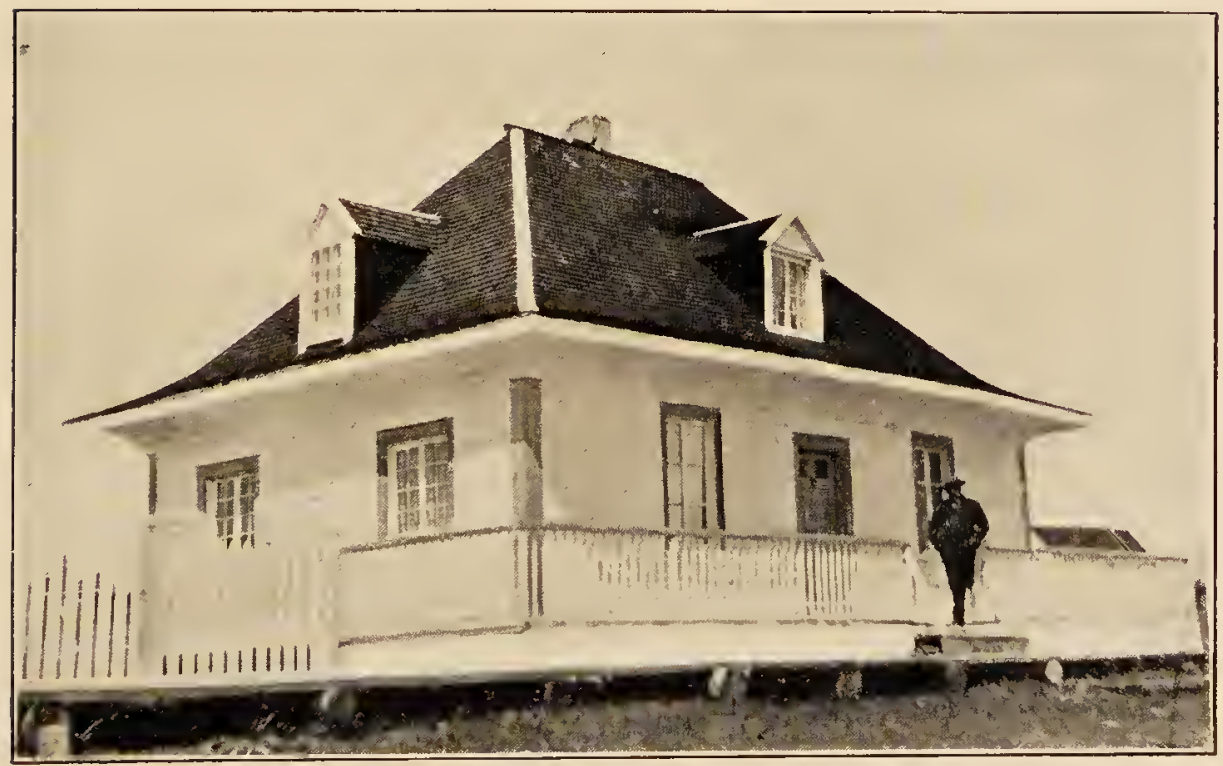

MR. J. A. WILSON, FACTOR AT THE H. B. C. POST AT MINGAN, ON THE STEPS OF THE COMPANY'S HOUSE BUILT BY MR. DONALD ALEXANDER SMITH, NOW LORD STRATHCONA AND MONT ROYAL. 



\section{THE MONTAGNAIS INDIANS}

wooden racks, generally decorated with drying stockings, mittens and moccasins. On hooks on the rafters were five guns of various makes and ages, the most formidable of which was a great muzzle-loader with a barrel three and a half feet long. Long benches were placed around the room for the convenience of the family and the visitors, and the conversation in the three different tongues was chiefly about salmon, although it may have wandered to other channels in the case of the blushing clerk and the eldest daughter.

Mingan has an interesting history. The company of the One Hundred Associates, also called the company of New France, was founded in 1627 by Cardinal Richelieu and five partners. Under them was held the "Terre ferme de Mingan," which was described as extending from Cape Cormorant on the west to "La Grand Anse " or "La Baie des Espagnols " on the east, and two leagues back. This eastern boundary has been liberally interpreted by the company as Bradore, while the crown recently contended that it was Agwanus. In I66I, or nine years before the Hudson's Bay Company received its charter, a charter was granted to 


\section{A LABRADOR SPRING}

Sieur Bissot de la Rivière for this seigniory of Mingan or Labrador Company as it was also called, and to this company the H. B. C. pays rent. The following notice is posted at Mingan:

"Notice is hereby given, that the Hudson's Bay Company are the Lessees of the following section of land in the Seigniory of Mingan, from the Labrador Company, viz.,

"From the west bank of the Mingan River running in a Northwesterly direction along the sea-coast to the east bank of the creek commonly known as Patterson's Brook, situated about half way between Long-Point of Mingan and Mingan proper, and running due North, a distance of two miles from the sea-coast.

"Any person found trespassing in the above defined land will be prosecuted according to law.

"HUDSON'S BAY COMPANY "per M. R. Grahame."

To avoid this rule and yet be able to do business with the Indians, an independent furtrader has built a store house on piles between tides near the Indian village, and carries on a trade with the Indians from a point he claims to be on the high seas, and therefore outside of the Seigniory! Our Belgian friend accomplishes the same purpose by anchoring his boat in the sound by Mingan, and trades with the Indians who bring out their furs in canoes; - "all is fair in trade and war!" 


\section{THE MONTAGNAIS INDIANS}

Hanging in the vestibule of the little office of the Post were several pairs of snow-shoes, discarded for a brief season between snows. The Labrador snow-shoe or racquette is almost everywhere tailless or nearly so; in fact their outline is almost circular or only slightly ovoid, but they make up in breadth what they lack in length. Some of them, however, have short rounded tails and are appropriately called "beaver-tails." The absence of tails makes progress through scrubby woods and brush easier than where the ordinary elongated shoes are used, and the Labrador racquettes are particularly adapted to the quick turns needed by those who hunt and tend traps. On that account they are very useful when one is following and studying birds, for with these shoes one can easily turn completely around in a small space, while with the long ones a considerable amount of backing and filling is necessary, as well as careful attention to the tails of the shoes, during which process the birds may be lost to sight. I have found them very satisfactory.

One of the buildings of the Hudson's Bay Company here at Mingan was built about 60 


\section{A LABRADOR SPRING}

years ago under the direction of Mr. Donald Alexander Smith, who was then the factor at this Post. Mr. Smith is now Lord Strathcona and Mont Royal, the head of this rich and powerful Company of Hudson's Bay. This historic house is not used now, as a larger one has since been built for the factor. It is a small single story square house, painted white, standing just to the eastward of the tiny office building, its platform surrounded by a neat white fence. The dark coloured roof with the usual upcurved edges is relieved by white dormer windows. A great knocker adorns the door, which has two small panes of glass set near the top. Lord Strathcona began his service for the Honourable Company as an apprentice at Rigolet in 1838 , and served for thirteen years on the Labrador coast. I could not help picturing the possible future of the young blue-eyed, fair-haired clerk, but a year out from Scotland, who was tactfully managing the black-eyed, dark-haired Indians at the store-house, and I was amused to hear him conversing with them in their own language with a broad Scotch accent. He seemed to be particularly successful in his sales of a calicc 


\section{THE MONTAGNAIS INDIANS}

that had won the hearts of the women, a real chef d'auvre in the calico line, for it was purple on one side and olive green with yellow spots on the other. The sales proceeded leisurely amid much talk and laughter.

Like the Indians I enjoyed wandering about the store-house, for it was an interesting place and contained everything that heart could desire in these regions. Furs alone were missing, for these are the medium of exchange, and for these the store-goods were bartered by the Indians, and the furs are transported to London. I should dearly have liked to be present during the trading process between the factor of the Post and the Indians, but I was told that the rules of the Company required that no outsider should be present - not even another Indian. The beaver skin is still the standard of exchange at this Post in terms of which all other furs are reckoned.

At the trading in the store, however, I was often present. The Indians are trusted implicitly, and are allowed to wander about the store, even in the absence of the clerk, and pick out what they like. Only once, the factor told me, was this trust misplaced, and it was 


\section{A LABRADOR SPRING}

only necessary to suggest that it might be the rule in future to lock the store except when the clerk was present. The square deal is appreciated by civilized and savage alike.

When one thinks of the treachery and deceit that have been practised by the whites in America in their dealings with the Indians and of the degradation and death wrought by the white man's cupidity, his diseases and his whiskey, one can not but be filled with shame and remorse, that this, the noblest race of primitive men, should have been treated so vilely. The unusually fine character of the unspoiled Indian we are discovering when it is too late, although Catlin pointed it out long ago, and for many years the inhuman saying has been flippantly repeated that there is "No good Indian but a dead one."

In former times the Indians coming from the interior erected their wigwams at Mingan near the trading post. Hind says. "Four hundred Montagnais had pitched their tents at Mingan, a fortnight before we arrived, there to dispose of their furs, the produce of the preceding winter's hunt, and to join in the religious ceremonies of the Roman Catholic church 


\section{THE MONTAGNAIS INDIANS}

under the ministration of Père Arnaud." This was in July, I86r. In 1889 the Hudson's Bay Company, in order to make the place as attractive as possible for the Indians, and as an inducement to bring their furs to this Post, built a small wooden house for the Indians and another three years later. These proved so attractive that the rest of the village was put up, we were told, in the years I901 to I903. However successful these houses may have been in stimulating trade, the effect on the health of the Indians has proved far otherwise. Infectious diseases, such as influenza and tuberculosis, were unknown among the primitive Indians, who have therefore developed no immunity, but, on the contrary, are especially susceptible to them and quickly succumb. When infected from the whites, they retire, like all ignorant people under the same circumstances, to their houses, and crowd together in close overheated rooms with doors and windows shut. The houses become therefore hotbeds of infection, and the course of the disease is hastened to a fatal termination.

Hind, writing of his visit in $186 \mathrm{I}$, records the fact that the Indians who lingered on the 


\section{A LABRADOR SPRING}

coast soon lost their energy and bodily strength and became prone to attacks of influenza, consumption and rheumatism. He speaks of a party of fifteen Nascaupees who had visited the coast at Seven Islands two years before, to see the robe noir. Seven of these had died, four had gone back to their own wilds, and, of the four that remained, all were very weak and one died while he was there. Hind attributed the illness and deaths on the coast to the unaccustomed climate, not recognizing the true cause of infection from the whites. But on the coast, he says, "the damp penetrates to his bones; he sits shivering over a smoky fire, loses heart, and sinks under the repeated attacks of influenza brought on by changes in the temperature."

When my profession was discovered by the Indians, I was in frequent demand, and was asked to prescribe for several patients whom I found to be far advanced in consumption. A pleasanter case to remember was that of a young Indian who told me that for two months he could not see out of one of his eyes; it caused him no pain whatever, and his only regret was that he could see the girls only 178 


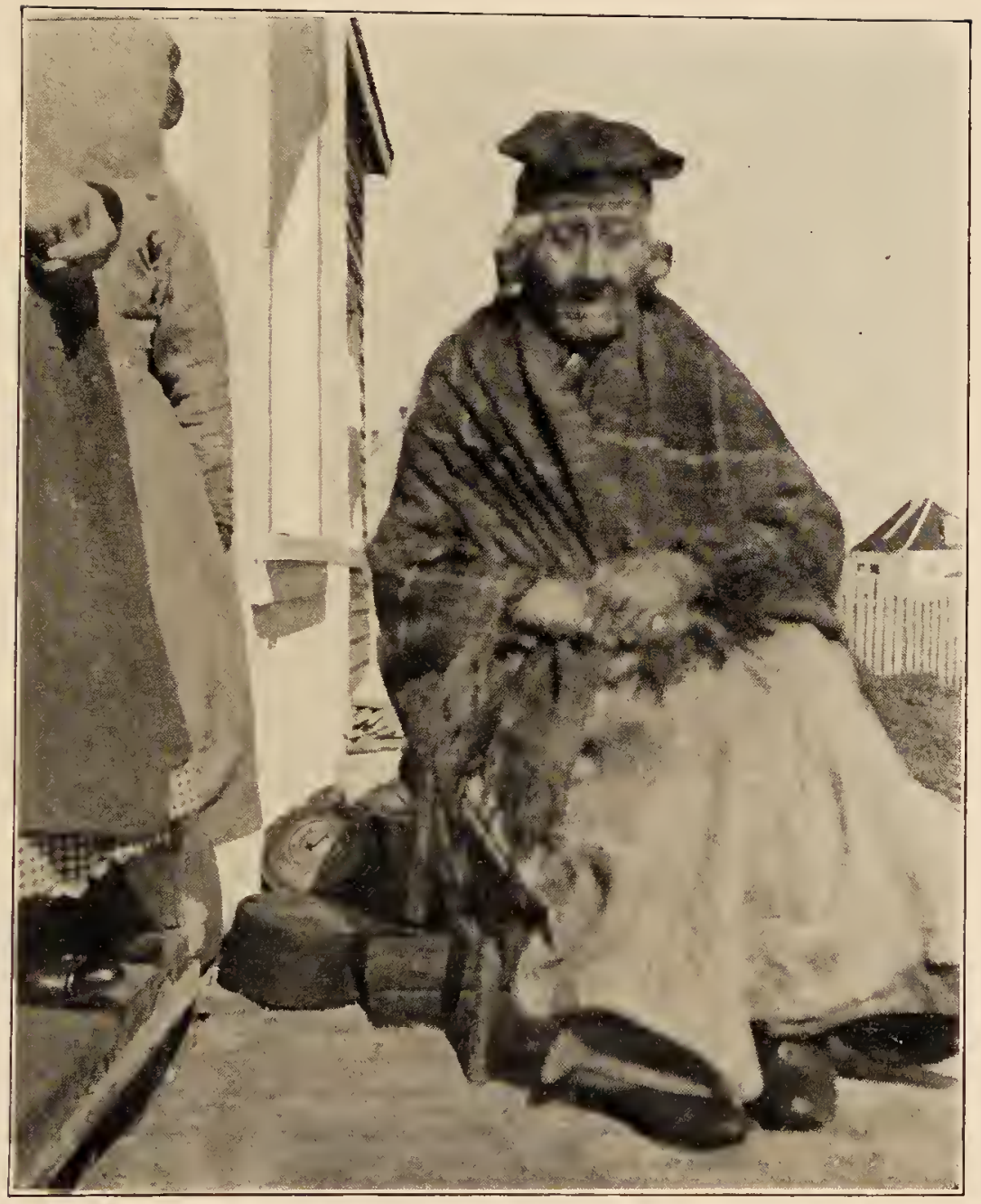

THE LAST LEAF ON THE TREE, SAID TO BE IO4 YEARS OLD. 



\section{THE MONTAGNAIS INDIANS}

through one eye instead of two. My interpreter for this gallant speech was one of the daughters of the salmon-fisher. As there was some slight redness of the eye, but more for the sake of giving the Indian the satisfaction of treatment, I presented him with some tablets for an eye wash. A few days later he reported that he had begun to see again in that eye!

That some of these people manage to survive the onslaught of the white man's germs of disease and live to a considerable age, was illustrated by an aged squaw at Mingan who was said to be 104 years old. The factor, Mr. Wilson, told me that up to within a few years she had spent the long winters with her people in the interior, but that increasing infirmities had at last compelled her to give up this strenuous life. She appeared to be still active mentally, and her small black eyes twinkled with intelligence in her sadly wizened face. When she walked she was bent like a bow, so that her chin almost touched her knees, and she reminded me of some Cape Cod women who are said never to die, but in the end to dry up and blow away like dead leaves. 


\section{CHAPTER VIII}

WINGS AND FEET IN THE AIR AND UNDER WATER

\footnotetext{
- Mark how the feathered tenants of the flood, With grace of motion that might scarcely seem Inferior to angelical, prolong Their curious pastime!"
}

- Wordsworth.

THE good priest at Esquimaux Point said that the devout could see the sign of the cross in the birds as they fly in the heavens. Our ideas of the flying birds may indeed be a conventional one, for their flight is generally so rapid that our impressions are often confused and incorrect unless our attention has been particularly called to some point. Thus in the case of the feet, artists and taxidermists alike generally represent soaring doves and eagles with their feet drawn up in front, and even excellent observers, who have not paid especial attention to the subject, are apt to agree in the accuracy of this stereotyped and conventional attitude. Now a little careful 180 


\section{WINGS AND FEET}

study of the familiar pigeon of our streets shows that in the case of the dove this view is an erroneous one. On rising from the ground the pigeon draws up its feet in front, it is true, but, as it gathers headway, the feet are drawn back and extended under the tail. In this position it soars or executes any flight more than a few yards. When it flies but a short distance it does not have time, or it does not take the trouble, to draw up its feet behind, but carries them in front to be ready to drop them when it alights. In quick turns I have seen them drop their feet a short distance from their tail, and once I saw one drop its legs so that they hung straight down for a few seconds, and were then extended behind again. In alighting the feet are thrown forward, generally at the last moment.

In the case of the eagle and other birds of prey the fact that the feet are carried behind under the tail has been observed over and over again, yet when this fact was announced in the pages of the Ibis in 1894 and 1895 there was at first a hint of protest, but numerous good observers confirmed the statement.

When the new United States twenty dollar 


\section{A LABRADOR SPRING}

gold piece appeared in 1907 with the design by St. Gaudens of an eagle in flight, its legs behind, objections were at once made. A writer in the Boston Transcript said: "Whoever saw an eagle in flight with its legs trailing behind it like a heron?" thus voicing the popular and conventional idea that the legs are carried in front. Although I have seen many wild hawks flying with their feet behind, sometimes trailing them with a distinct gap between the tail and the legs, for all the world like the St. Gaudens' design, my most satisfactory views have been those of ospreys at Bristol, Rhode Island, where the birds are semi-domesticated, for they build their nests on tall poles, erected for their convenience in barn yards, and allow inspection at close range. Here there can be no question but that they carry the feet behind in flight.

Owls also dispose of their legs in the same manner as I have observed in a great horned owl confined in a flying cage, and in a wild barred owl seen flying about its nest.

The same habits exist among the pheasants, grouse and partridges. I have not been able to see the feet in the rapid flight of the ruffed 


\section{WINGS AND FEET}

grouse and bob-white, but in the introduced ring pheasant I once watched a flock of young birds in flight whose only partly grown tails did not conceal the long legs of the birds that extended backwards. In side views of the splendid cock pheasants I have also seen the legs extended behind.

In the case of the water birds that abound on the Labrador coast it is easy to see that the legs are carried behind, and this is the universal habit among all groups of this order. The puffin and sea pigeon with their brilliant scarlet feet make it plain as to their position in flight. The gulls habitually carry their feet behind, and in quick turns generally drop their feet pressed together, suggesting their use as a centreboard, for, as in a centre-board boat, quick turns with the board up are impossible, - with it down these turns become easy. Gulls have also a habit of sometimes drawing up one or both feet in front. Sometimes the feet carried forward show plainly, at other times they are buried all but the toes which appear as dark nobs, and again they are entirely concealed in the feathers of the breast so that the bird appears to be destitute of feet. Birds with one 


\section{A LABRADOR SPRING}

foot concealed in front and one carried behind appear to have only one foot. It is possible that the birds do this to keep the feet warm, but I have observed the habit in mild weather.

The dexterity with which the herons manage their ungainly legs, stretching them behind in flight, is familiar to all. I once saw a great blue heron attacked in mid-air from the rear by a screaming tern. The heron was so startled that it dropped for a moment its long legs, and stretched out and around its snake-like neck. It may be stated as a rule to which, as far as I know, there are no exceptions, that all water birds carry their feet behind in flight.

It is probable that parrots, cuckoos and kingfishers all carry their feet behind, but very few observations have been made in these difficult cases.

In the woodpeckers the feet are I believe carried in front, while instantaneous photographs of humming birds show that in hovering, at least, the feet of this bird are also carried in front.

In the great order of perching birds it would seem natural that the feet should be carried in front as they fly from place to place, so as 


\section{WINGS AND FEET}

to be ready to seize their perch, and as far as I know this is always the case. The crow is our largest common perching bird, but its black colour of plumage and feet alike make it difficult to observe the point in question. A crow in rising on the wing often lets its feet hang at first, and then draws them up in front in an exceedingly leisurely manner. When well under way the feet are close against the breast, and are held there I am inclined to believe, even in long flights, for I have several times observed crows from a point on a sea beach where I could follow their flight for a long distance, and, as they passed me, their feet were always in front. The feet are sometimes dropped slightly so that daylight can be seen between them and the breast, or held so closely to the breast that only the clenched toes can be seen, and these in some cases are entirely buried in the feathers. If the bird had only been so obliging as to have white feet, these observations would have been much easier.

I have also seen the feet when the birds were in full flight in the case of swallows, blackbirds, robins, the familiar house sparrow of the 


\section{A LABRADOR SPRING}

streets and in other perching birds, and they were always held in front.

The modern study of birds by means of powerful prismatic binoculars and occasionally of telescopes reveals much that was concealed from the students that depended on the naked eye and the loaded gun, and those who were brought up in the " collecting age," unless they have fully adopted modern methods, are apt to look with some suspicion on those who use glasses. The student who leaves the gun at home or keeps it judiciously in the background, not only sees more with these glasses, but also with the naked eye, for the birds soon recognize the difference between the man with the gun and the man with the glasses, and behave accordingly, and this is a point that the oldtime student does not appreciate. For years I never got nearer than a long gun-shot from an adult turnstone and never observed him for any length of time at that distance, but, since adopting modern methods, I have spent many interesting half-hours with these birds, at times so close that I could not focus my glasses on them, and have watched every detail of their actions in turning over seaweed and 


\section{WINGS AND FEET}

stones. The case of the Ipswich sparrow, a bird that breeds only at Sable Island and visits the sandy Atlantic shores in winter, is a striking illustration of the difference in the two methods. Formerly ornithologists made visits to the seashore dunes in late fall and early spring, and considered themselves fortunate if they flushed half a dozen of these birds at long range in a day's tramp, and succeeded in shooting two or three on the wing. Now the student watches them within a few yards, and is able to note all the peculiarities of markings and habits. I. have tried both methods and I know whereof I speak. In a comparatively unexplored region like Labrador, however, it is well to have two strings to one's bow.

Being burdened somewhat with a New England conscience, I am glad I began bird-study before the days of hand-books and Audubon societies, in the good old times when a gun was used for identification, for I think that course of study gives one a grounding that it is difficult to get otherwise. Nowadays there is no excuse for the beginner to use a gun, and there is no need of multiplying collections of bird-skins, but it should be impressed on all 


\section{A LABRADOR SPRING}

bird-students - and their name is legion, both masculine and feminine - that it is far better to be silent or confess ignorance than to affirm knowledge unless that knowledge is based on sound observation. It is to be regretted that too many ardent bird-students are not only lacking in powers of observation and in appreciation of the scientific value of truth, but also that they possess imaginations which lead them to see what the text-books have given them to expect. Above all they should avoid embarrassing ornithologists by recording in print imperfect and erroneous observations, and they should remember that by so doing they discredit not only themselves but the whole class of gunless observers.

Turn we now, as dear old Professor Shaler used to say, to another subject. Instantaneous photography shows that birds extend the bastard wing just as they alight. The bastard wing consists of a few stiff feathers attached to the so-called thumb on the front edge of the bird's wing. Ordinarily it lies flat and is not seen, but just as the bird alights from a flight it is extended so as to be partially detached from the main wing. In the domestic pigeon 188 


\section{WINGS AND FEET}

I have often observed this with the naked eye, although I hesitate to record this observation for fear that someone who has been reading Munsterberg will say that I merely visualized what the photograph made me expect to see. It is an observation, however, that any one can make whose eyesight is ordinarily good. A bird comes sailing down from a roof, and, as it approaches the ground, the bastard wing becomes distinctly prominent, the whole wings are then flapped rapidly, during which it is impossible to observe them distinctly, and the bird drops to its feet. The natural explanation of this action of the bastard wing is that it is used to check the progress of the bird, to back water so to speak, but the bastard wing is so small that its power in this direction must be extremely slight. One might suggest, therefore, that the present bastard wing is but a vestige of its former self, and dates back to a time when its use was of value, or, to go back still farther in the family tree, one might suppose, perhaps fancifully, that the bird thus puts out its thumb as did its reptilian ancestors to grasp the perch to which it is speeding.

The Labrador coast is a good place to study 189 


\section{A LABRADOR SPRING}

diving birds, for there are many and of numerous kinds to be found there. It is evident that these birds may be divided into two main classes, those that habitually use the wings alone under water, and those that use the feet alone. Those that use the wings make ready before they disappear below the surface by spreading or flopping them out, while the feet-users keep the wings tightly clapped to the sides, and they often execute graceful curves in diving, sometimes leaping clear of the water.

The puffin is a good example of the former class, and its wings are plainly to be seen in vigorous use as it goes under water, and it often comes out of the waves flying, only to return to the denser element again with the same method of propulsion. All the other members of the auk family dive in the same way. I have twice had excellent opportunities to watch dovkies or little auks swimming close at hand under water, and plainly saw them use their wings. The great auk, long since extinct, with wings reduced to flipper-like proportions, doubtless advanced rapidly through the water by the action of these extremities only, for the feet in the living members of this group are not 


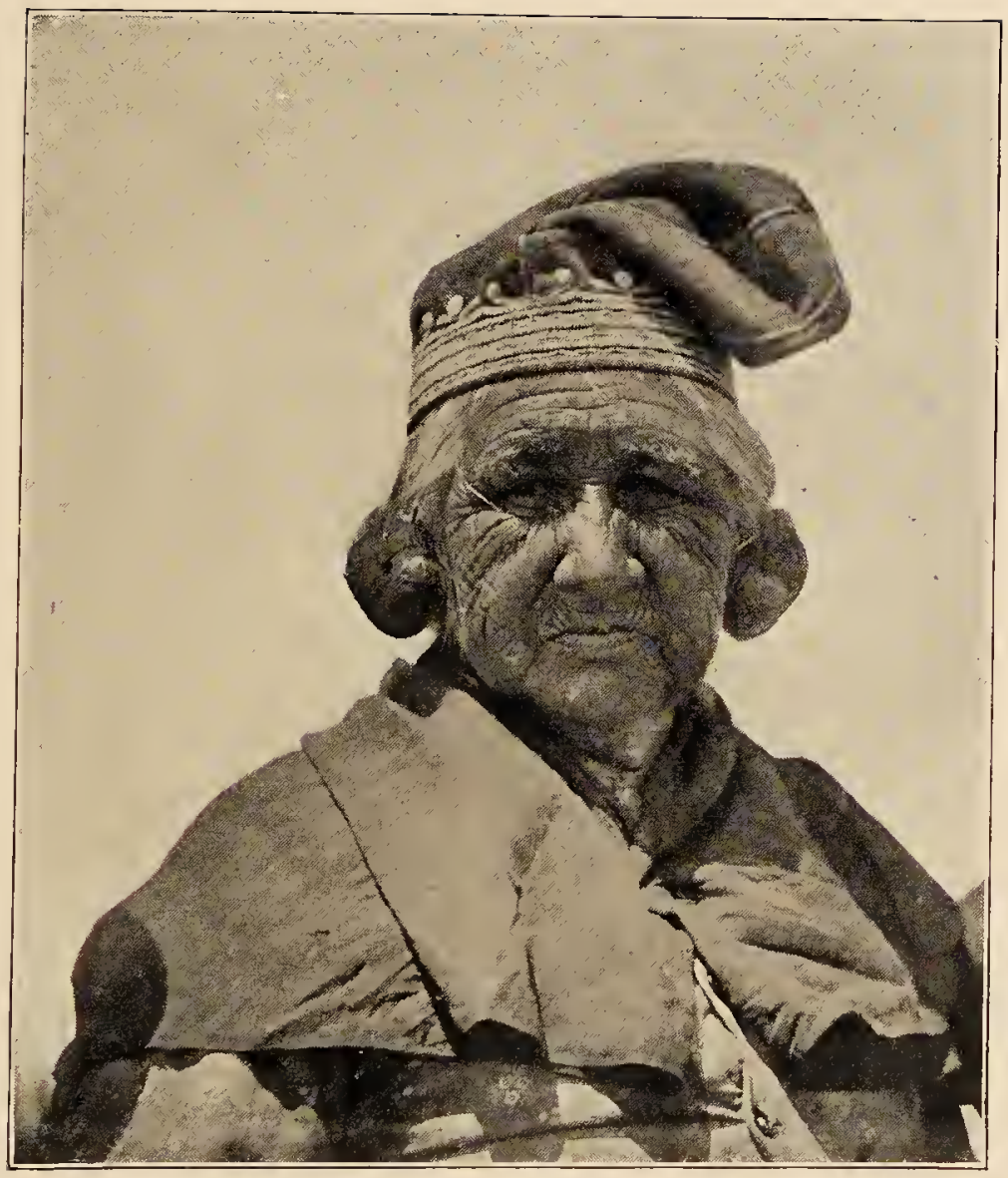

MY ESCORT AMONG THE INDIANS AT MINGAN. 



\section{WINGS AND FEET}

used for propulsion under water. The penguins, although entirely distinct from the auks, fly through the water with their extended flipperlike wings, and, from the testimony of those who have watched them in tanks, it is learned that the feet are not used. Thus Lea ${ }^{\mathbf{I}}$ says of these curious birds: "Their flight may be watched and studied in the large glass tanks at the Zoo. . . With short, rapid strokes of its paddle wings it darts through the water leaving a trail of glistening bubbles behind, and shoots forward with the speed of a fish, turning more rapidly than almost any bird of the air by the strokes of the wing alone, the legs floating apparently inert in a line with the gleaming body, or giving an occasional upward kick to force it to greater depths."

One is apt to assume that "the trail of glistening bubbles " which comes from a diving bird are the expired air bubbles, but I am inclined to think that most if not all of this air is expelled from the feathers in order to make diving more easy or even possible. Some diving birds have the ability to sink gradually out of sight in the water with apparently little

${ }^{1}$ John Lea, The Romance of Bird Life, 1909, pp. 202-203. 


\section{A LABRADOR SPRING}

or no muscular effort, yet these same birds shot on the wing float on the surface when dead as lightly as feathers. Each body feather is governed by tiny muscles, and by their action the feathers can be depressed so that the large amount of air normally held between them is expelled, and the body loses its buoyancy. I was interested to try the experiment on a recently killed eider on this trip on the Labrador coast, and found that while the dead body floated high in the water, by expelling the air from the feathers and replacing it with water the bird sank so deeply that only a small fraction appeared above the surface. This simple experiment, therefore, explains the otherwise mysterious power of some water birds to sink in the water without apparent leg or wing action. After rising to the surface from diving, birds usually shake themselves as if to admit air to their feathers.

Among the ducks, old squaws, scoters, and eiders, all common Labrador birds, plainly use their wings in diving. Once, while watching some old squaws sporting in the water and chasing each other on or just below the surface, I distinctly saw the wing of one of them cut the water from 


\section{WINGS AND FEET}

below like the fin of a great fish, and I have seen a surf scoter near at hand fly under water.

It is a curious thing, when one stops to think of it, that some species of ducks like those named above should vigorously fly under water, while other ducks should keep their wings close to their sides and shoot about under water by the action of their feet alone, yet this seems to be the case. The redhead and the canvasback, the scaups, the whistler or golden-eye and the bufflehead all seem to disregard their wings under water and use the feet alone. This is also true of the mergansers, who always dive with the wings pressed closely to the sides. Edmund Selous, who has watched water birds from vantage points on the cliffs of the Shetland Islands, says: "The merganser dives like the shag or cormorant - though the curved leap is a little less vigorous - and swims like them, without using the wings. His food being fish, he usually swims horizontally, sometimes only just beneath the surface, and, as he comes right into the shallow inlets, where the water almost laps the shore, he can often be watched thus gliding in rapid pursuit." '

${ }^{1}$ Bird Watching, London, I90I, p. I53. 


\section{A LABRADOR SPRING}

The group of river ducks, on the other hand, which includes the teals, mallard, black duck and wood duck, are not skilled in diving but obtain their food by dipping their heads and necks below the surface, while their tails point to the zenith in the ardour of the pursuit. These birds as well as geese and brant do, however, occasionally dive in an awkward manner, and in so doing use both feet and wings.

The family of the loons and grebes is a curious one and its members are characterized by possessing very muscular legs, the thighs short and stout, the lower legs long and provided with keels for the attachment of powerful muscles. The grebes have also a very large knee-cap. In these respects the group resembles the fossil Hesperornis, a toothed bird with wings represented by mere vestiges, but one that was evidently strongly specialized for propulsion through the water by means of the feet alone. Now loons and grebes are expert divers, and, although they occasionally have been seen to use the wings when hard pressed, as a rule they appear to swim, and that too very rapidly, under water with the feet alone. Young loons, 


\section{WINGS AND FEET}

however, scramble away under water, using both feet and wings.

Cormorants are famed for their ability to swim under water with great swiftness, and domesticated ones are used at the present day by the Chinese as catchers of fish, while a ring around the neck prevents the bird from profiting by its labours. Both when confined in tanks and wild in the sea this curious bird uses its feet alone for propulsion. Selous ${ }^{\mathrm{I}}$ says of these birds: "Others, whose young were still with them on the nest, although full fledged and almost as big as themselves, plunged, attended by these into the water. . . It was easy to follow these birds as they swam midway between the surface of the water and the white pebbled floor of the cavern, and I am thus able to confirm my previous conviction that the feet alone are used by them in swimming, without any help from the wings, which are kept all the while closed." The American coot or mud-hen, a bird of the rail family, is a graceful diver, and, like the cormorant, it keeps its wings close to the

${ }^{1}$ The bird Watcher in the Shetlands. London. I905. p. 50 . 


\section{A LABRADOR SPRING}

body. Selous, ${ }^{1}$ however, says of the English moorhen, another rail, that he " may follow no fixed plan in his diving, for I have certainly seen him using his feet only under water, and I believe I have also seen him using his wings."

Very young spotted sandpipers, the familiar teter-tail of beaches fresh and salt, sometimes dive when hard pressed, and in so doing use both wings and feet. The water ousel uses both wings and feet under water.

It would seem, therefore, that with a few exceptions diving birds tend to specialize in two directions, - either towards the use of the feet alone, or of the wings alone. The question naturally arises as to which line is superior, which has produced the swiftest diving bird, - the line that has led to the use of the feet alone or that which has led to the use of the wings alone? It is evident that a method of diving which leaves the wings unimpaired in size or form for the use in the air is a desirable one, and that this is possible where the feet alone are used. In most fishes propulsion is from the rear by means of the tail, for the pectoral fins, which correspond to

I Bird Watching. London, 19oI, p. I56. 


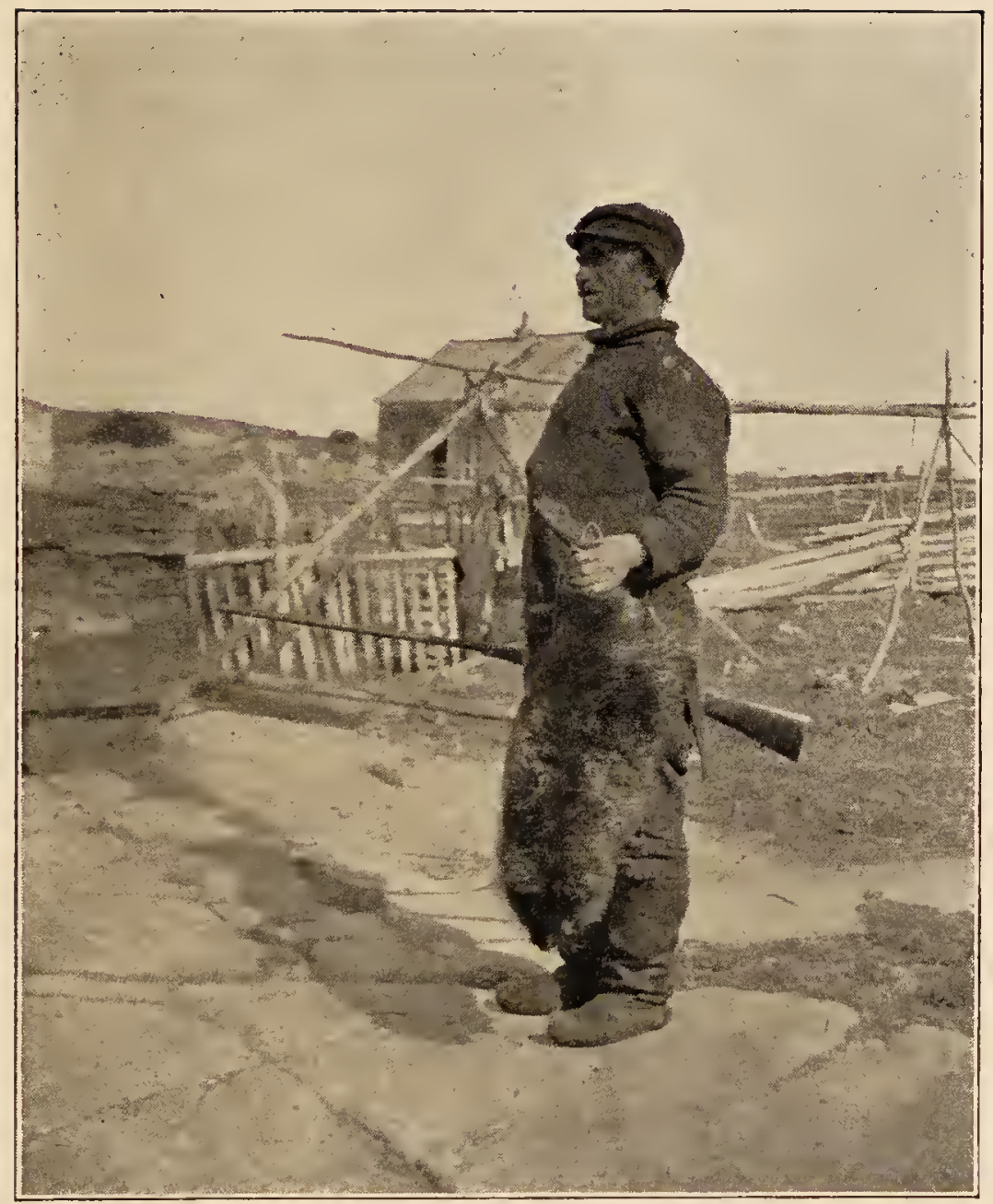

PIERRE OF PIASHTE-BAI AND THE BEAVER, SHOWING WEBBED HIND FOOT OF THE BEAVER, AND "SKIN BOOTS" OF MAN. 



\section{WINGS AND FEET}

the birds' wings, are used chiefly for balancing, and when the fish swims fast these fins are kept close to the sides. Among mammals the cetaceans have developed greatest speed in diving and swimming under water, and here also the tail is the propulsive power, while the anterior extremities are used chiefly for balancing. The beaver, with its posterior extremities alone webbed, uses these only in swimming under water. The modern screw-propeller is superior to the old side-wheeler.

In hesperornis the wing is a mere vestige, but the leg bones are of great strength. It is evident that hesperornis pursued its prey under water by means of the feet alone, and that through many generations it had gradually lost the use of the wings, which must have been, therefore, a hindrance rather than a help in its subaqueous flight. It had long since given up aerial flight. Loons and grebes, however, although apparently allied to hesperornis, do at times, as we have seen, use their wings in addition to their feet under water, yet it seems to me probable from the evidence adduced that as a rule they progress by the feet alone. The young appear to use the wings as well as the 


\section{A LABRADOR SPRING}

feet habitually. These facts would seem to indicate that the method of posterior propulsion in loons and grebes has not been long developed nor permanently fixed, and that the young show the ancestral or primitive form of locomotion. The close resemblance in the legs of the loons and grebes on the one hand, and hesperornis on the other, would suggest either a case of parallelism from similar functions, or that they were all descended from the same stock. In the "Birds of Essex County" I I spoke of the loon as " approaching the wingless conditions." The present studies would, however, lead me to believe that the loon, in perfecting the method of posterior propulsion under water, has no need to reduce the size of its wings for use there. It can, however, with advantage increase their size, provided it does not use them under water, for the wings are now so small that on calm days it is unable to rise into the air.

Cormorants on the other hand have for so long a time perfected the posterior propulsion method that they do not use the wings under water even apparently when young. In con-

${ }^{1}$ Birds of Essex County, Cambridge, 1905, p. 80. 


\section{WINGS AND FEET}

sequence they have been able to retain large wings for aerial flight. That they can develop great speed under water and are very expert fish-catchers is well known.

The other line of evolution, the subaqueous flight by anterior propulsion, or by the use of the wings alone, reaches its height in the penguins, and probably in the extinct great auk, two birds widely separated genetically but converging to the same result in this particular. Both birds in developing speed under water by the use of the wings, reduced them in size to the proportions of seal's flippers, most markedly so in the case of the penguins, thereby showing that large wings are not only unnecessary, but even a hindrance in subaqueous flight. In attaining this end they were obliged to sacrifice aerial flight. This the penguins were able to do owing to the absence of land mammals in their antarctic breeding grounds. The same conditions existed for the greak auk at its chief breeding place in this country on Funk Island, until the arrival of that most destructive land mammal, the white man.

The diving petrel of the Straits of Magellan 


\section{A LABRADOR SPRING}

is a bird that appears to be in danger of sacrificing aerial for subaqueous flight, and illustrates the inconveniences of this line of evolution. Nichol ${ }^{1}$ says of this bird, after describing its short flights in the air and its diving: "In appearance it reminds one forcibly of the little auk. . . The wings are very small and weak, the bird, doubtless, is losing the power of flight."

In the case of the existing auks and of the other birds that habitually use the wings alone in diving, it would be interesting to determine whether they are able to progress under water as fast as those birds that use the feet alone, for the auks are trying to make the same tool work for two purposes, to propel them in the air as well as in the water. One is impressed with the imperfection of their wings for bcth purposes, when one watches a puffin endeavouring to get out of the way of a stesmer. First the bird dives and flies under water. Then in alarm it rises to the surface and attempts to ascend into the air on its wings, but unless there is a strong wind to act on its small aeroplanes, it soon gives up the attempt and

${ }^{1}$ Three Voyages of a Naturalist, London, 1908, p. 160. 200 


\section{WINGS AND FEET}

flops down into the water again. Although it would be difficult to prove, it would seem to me reasonable to suppose that the compressed pointed body of the loon, with the air expelled from beneath the flattened feathers, would make faster progress by feet action alone, than by the wings or by the wings and feet combined, unless the wings were reduced to the proportions of flippers. It is possible that the occasional use of the wings observed in these birds may be explained by fright, which causes them to "lose their heads," and return to the ancestral form of progression, to a reptilian scramble so to speak, without increasing the speed of their progress. It could also be argued that the wings of loons are now so reduced in size that their use in emergencies under water is a help and not a hindrance. Experiments on captive birds in tanks might determine these facts. ${ }^{1}$

${ }^{1}$ The persistent but futile efforts of the loons to rise from the water in flight during a calm on the approach of the steamer as described in the second chapter is, it seems to me, another illustration of the return to primitive methods during extreme fright. Aerial flight was doubtless practised by the ancestors of the loons long before subaqueous flight, and in subaqueous flight it is reasonable to suppose that quadrupedal action antedated that of the feet alone. 


\section{A LABRADOR SPRING}

That loons are able to progress faster under water than on the surface I have concluded from such observations as the following: ${ }^{x}$ "Thus on one occasion I was watching a loon swimming about, dipping his head under water from time to time on the lookout for food. The cry of another loon was heard at a distance and my friend immediately dove in the direction of the other, and, appearing on the surface for a moment, dove again and again until he reached his companion. At another time on the Maine coast while watching a flock of young Red-breasted Mergansers swimming off the shore, I noticed a movement as of a large fish on the water outside. The mergansers at once flapped in alarm along the surface of the water towards the shore where I was hidden, and I soon saw that a loon was chasing them, following them under water." Theoretically a loon should be able to go faster under water than on the surface, for on the surface the bird is retarded by the waves in front and the eddies behind, and the faster it goes the more it is retarded by these factors. The subject of the resistance of submerged

${ }^{2}$ Birds of Essex County, 1905, p. 80. 


\section{WINGS AND FEET}

bodies has been exhaustively studied by naval architects, and it has been shown that a properly shaped body completely submerged under ideal circumstances with the wave eliminated meets with little resistance besides friction. The fact that a loon when swimming rapidly on the surface is apt to depress its body in the water so that its back is awash seems to favour this contention. It may be argued that the bird does this to avoid observation or to escape being shot, but it certainly swims faster when thus submerged. Under water the diving bird has a great advantage in being able to assume a shape best adapted to cleaving the liquid medium.

Incidentally it may be remarked that the loon, in perfecting its legs for use under water, has disabled itself for walking on the land, but as it usually builds its nest on or close to the water, it can well afford to sacrifice terrestrial locomotion.

The combined use of wings and feet, a reptilian form of progression, would naturally be found among birds that had not fully specialized in either direction. Among living birds the cormorant and the penguin represent 203 


\section{A LABRADOR SPRING}

the extremes of specialization for the posterior and anterior extremity respectively. Where either habit is not firmly established we should expect at times a return to the primitive method, and we should expect to find it in young birds. This is well shown in the case of the loon. We should expect to find it at all times in behinners in the art of diving, $i . e$, among birds whose ancestry in the diving line is not a long one. The mallard, the black duck, the moorhen, the spotted sand piper and the water ouzel may perhaps illustrate this contention.

In conclusion the following tentative inferences from these preliminary studies on diving birds may be set down.

Ist. That progression by both the wings and feet under water in diving birds is the primitive method, and is therefore to be looked for among beginners and young birds.

2d. That specialization towards the use of the wings alone leads to a diminution in the size of the wings, and finally to a form of bird that is flightless in the air; for wings of flipper proportions, too small for aerial flight, are more efficient than large wings for subaqueous 


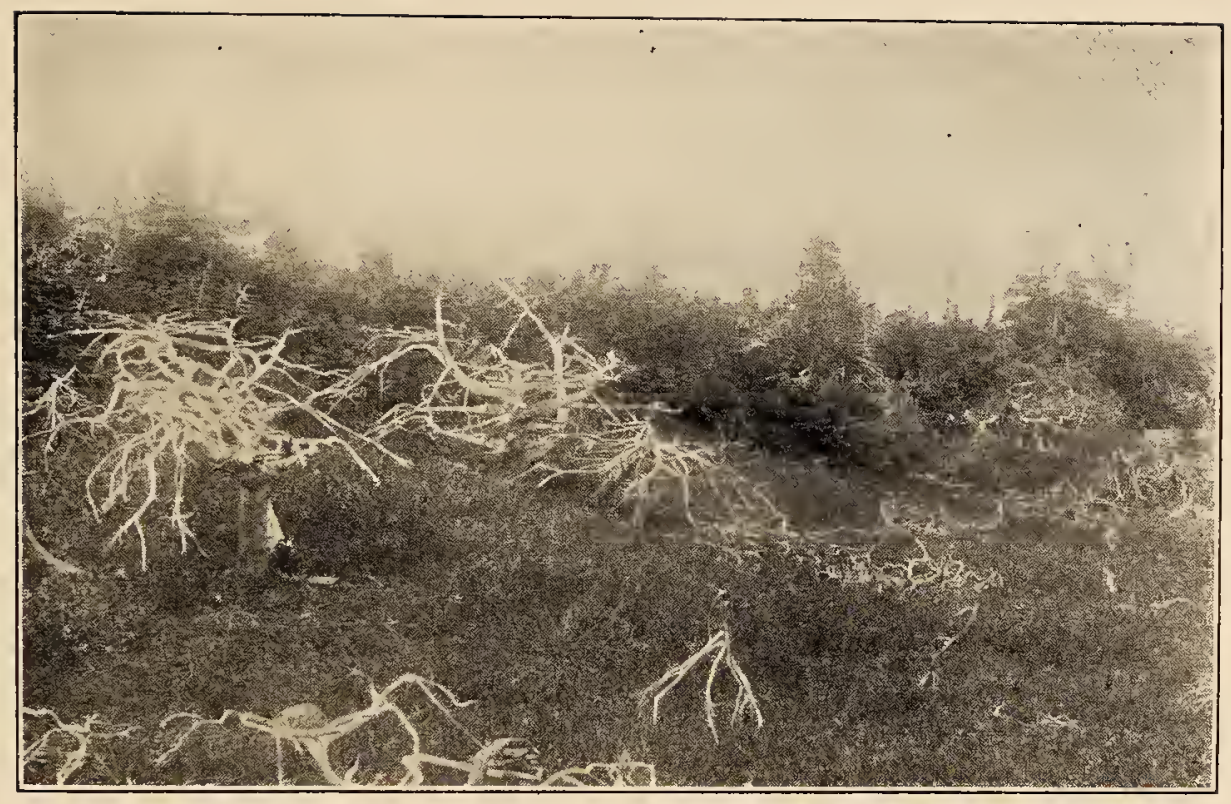

DWARFED SPRUCES DEAD AND ALIVE AT ESQUIMAUX ISLAND.

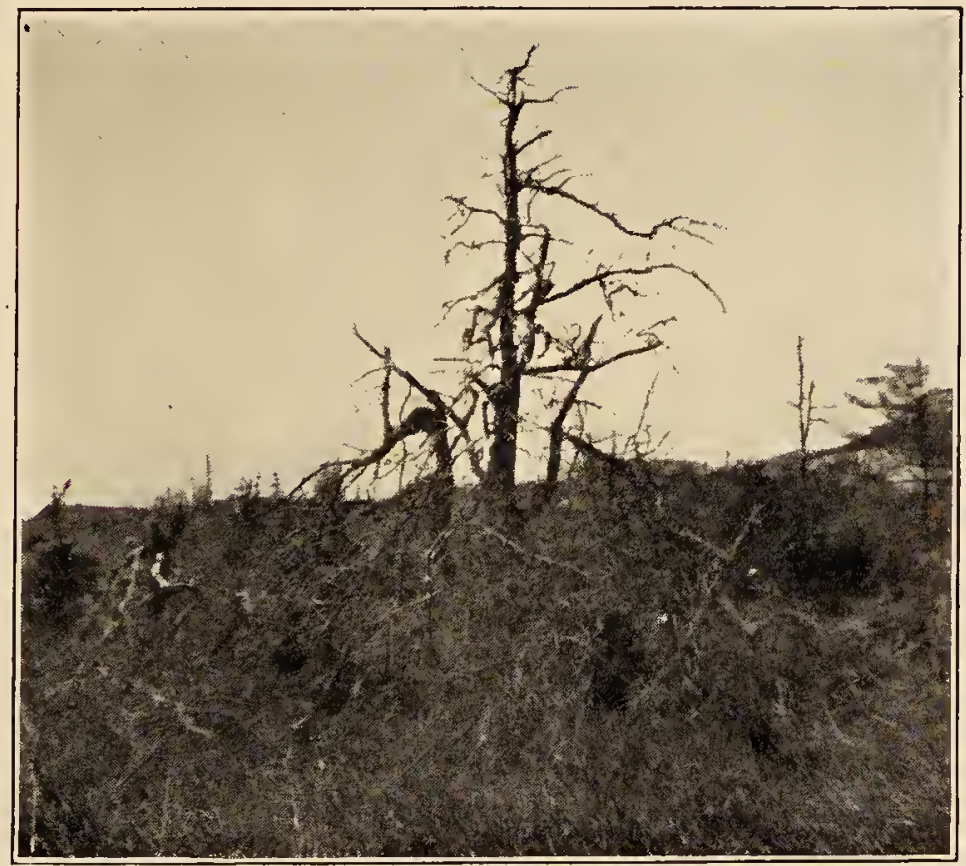

ANCIENT LARCH AT QUATACHOO. 



\section{WINGS AND FEET}

flight, as witness the great auk and penguins.

3d. That specialization towards the use of the feet alone is probably best adapted for the most rapid progression under water, and this method may leave the wings undiminished in size for use in the air. The apparent exception, hesperornis, with powerful feet but with wings degenerated to vestiges through disuse, serves but to confirm the inference of the superiority under water of feet action alone. 


\section{CHAPTER IX}

\section{SOME LABRADOR TREES \\ "Arbores magnae diu crescunt; \\ Una hora extirpantur." \\ - Curtius.}

$\mathrm{E}^{\text {NOS A. MILLS }}$ has recently described the incidents in the life of a giant yellow pine, in the stump of which he counted 1047 rings. From this he concluded that the year of the great tree's birth was somewhere in the ninth century after Christ. A long and careful dissection and study of the fallen monarch that in life had attained a height of over a hundred and fifteen feet, and a trunk eight feet in diameter, revealed many secrets. The rings showed seasons of drought or cold, periods of prosperity and again of stress and injury. Lightning and fire left their indelible marks, as well as the effect of heavy winter snows; two imprisoned stone arrow heads and

${ }^{1}$ Wild Life on the Rockies. Boston, I909, p. 3I. 


\section{SOME LABRADOR TREES}

some rifle bullets suggested interesting incidents, and an imbedded stone on the cliff side of the tree together with fractures of roots that had occurred in the year I 8 I I or I 8 I 2 suggested an earthquake.

Nothing of this spectacular sort did I find in my study of Labrador trees, but I had determined on this trip to make as many sections of the trees as I could, and I had brought a saw for the purpose, because in my previous visit to Labrador I had cut down and sectioned a few of the dwarf specimens with the best instrument I then had, a sheath knife, and found they were all tough and some of them were surprisingly old and interesting. Thus: " A little larch that had successfully risen to the great height of nine inches in a gully, I found on sectioning and counting the rings with a pocket lens to be thirty-two years old. The massive trunk was three-eighths of an inch in diameter. A balsam fir with a spread of branches of twenty-seven inches, whose topmost twig was thirteen inches from the ground, showed fifty-four rings in a massive trunk two inches in diameter. Another balsam fir nine inches high and twenty-one inches in extent 


\section{A LABRADOR SPRING}

showed thirty-five rings in a trunk one inch and a quarter in diameter. A black spruce eleven inches tall and twenty-two in extent, with a trunk only one inch in diameter, had lived over half a century, showing fifty-two rings in its cross section. The sturdy little veteran wreaked his vengeance on me by making a great nick in the sheath-knife with which I laboured to dissect him and learn his secrets." I

In this Labrador spring I counted the rings on the large stumps and in some of the smaller ones on the spot, but most of my studies are from sections that I cut and labelled, and afterwards studied at home, for the Labrador spring is so short. When the tree has grown rapidly the rings are wide and easily counted by the naked eye, but in most of the stunted Labrador trees the growth is so slow that a strong hand lens is necessary, and in some of the smaller, much stunted ones I made the sections with a razor, mounted them in a drop of oil, and counted the rings with the low power of a compound microscope. I found that careful smoothing of the section with a razor or sharp knife and oiling it brought ${ }^{1}$ Along the Labrador Coast. Boston, 1907, pp. 43-44. 


\section{SOME LABRADOR TREES}

out the rings more plainly and it was often possible by shifting around the circle to count the full number of rings, when in a direct line to the periphery from the centre, portions of the rings might be illegible. Pins used in the larger sections to mark off various points in the counting were also of help. Most of the sections were counted two or more times and an average struck in case of disagreement, so that I believe my counts are fairly accurate.

I made in this way an examination of twentysix trees, larches, balsam firs, and black and white spruces that varied in height from one and a half inches to fifty-five feet. The most stunted specimens, the ones that grew the slowest and were least in height, were to be found on the sea-shore and in the bogs. Beyond the Mingan Islands the shore and particularly the islands took on a more arctic appearance, and, in places exposed to the full fury of the wind, the trees were prone on the ground, although, even as far east as Natashquan, trees of twenty feet in height were found close to the shore in fairly protected places. The bogs, with their deep sphagnum moss and acid waters, their underlying ice even in June, 


\section{A LABRADOR SPRING}

and their exposure to the full fury of all the winds that blew, appeared to be particularly difficult places for the growth of trees, yet it was evident that it was only by the slow growth through many years of these trees and bushes that the bog was consolidated and became fitted for the support of a large growth. The forest works in from the sides and extends in islands, so gradually that centuries must elapse before the progress is even noticeable. The truth of this statement is made probable by the following observations on trees of the bogs. Thus in one of the bogs on top of Esquimaux Island, a balsam fir whose trunk was three-quarters of an inch in diameter, whose height was twelve inches and the extent of whose branches was twenty-four inches showed by its rings a struggle of twenty-four years. A black spruce six inches high with a trunk one and one-half inches in diameter was fifty-three years old. Another black spruce nine inches high and one-half an inch in diameter was sixty-two years old.

Larches are common enough in the bogs, but one must look carefully in order to pick up a little tree with a trunk one-eighth of an inch 


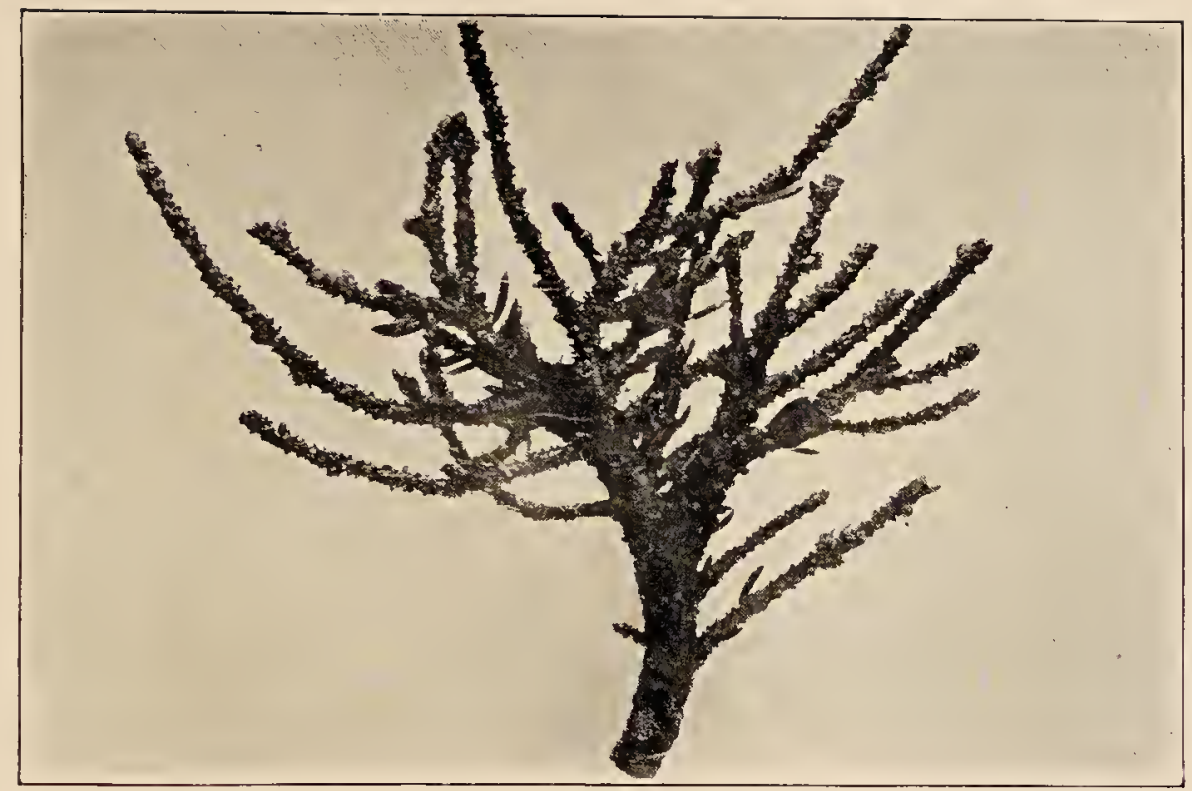

LARCH TREE SIXTEEN YEARS OLD, FROM BOG AT ESQUIMAUX ISLAND* SLIGHTLY ENLARGED.

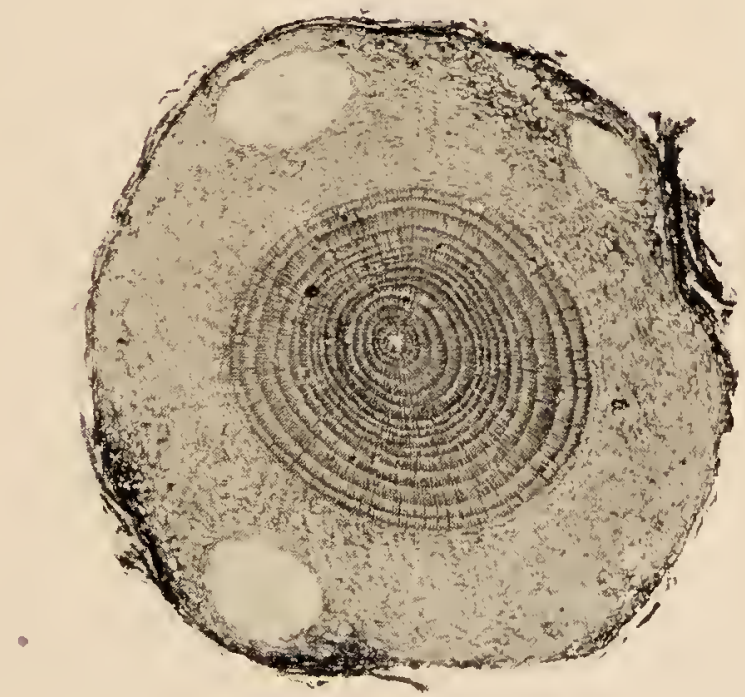

PHOTOMICROGRAPH OF SECTION OF TRUNK SHOWING SIXTEEN ANNUAL RINGS.

Photographs by Prof. E. C. Jeffrey and Mr. E. W. Sinnott. 


\section{SOME LABRADOR TREES}

thick, a height of one and one-half inches and a spread of branches two inches across. Yet this was not a seedling, for sixteen years as shown by its rings under a powerful microscope had passed over its head. It seemed cruel to pluck up such a tree after it had been so well started in life, and tuck it into one's vest pocket. The other larches, and there were ten of them, that I measured, sectioned and counted from the bogs of Esquimaux Island gave the following figures:

\begin{tabular}{|c|c|c|c|}
\hline $\begin{array}{c}\text { Height } \\
\text { of } \\
\text { tree. }\end{array}$ & $\begin{array}{l}\text { Extent } \\
\text { of } \\
\text { branches. }\end{array}$ & $\begin{array}{c}\text { Diameter } \\
\text { of } \\
\text { trunk. }\end{array}$ & Rings. \\
\hline 12 inches & 38 inches & 2 inches & 55 \\
\hline $3 \frac{1}{2} \quad$ " & $8 \quad$ “ & I $\quad 6$ & 42 \\
\hline 6 " & 30 " " & $\frac{5}{8} \quad 11$ & 43 \\
\hline 54 & 84 & $\frac{3}{4} \quad 6$ & $3^{I}$ \\
\hline 124 & $24 "$ & $\frac{1}{2} \quad 16$ & 45 \\
\hline & & $\begin{array}{ll}3 & 1 \\
1 & 1\end{array}$ & $\begin{array}{r}38 \\
8\end{array}$ \\
\hline " & $2 " 1$ & $\frac{1}{8}$ & 8 \\
\hline “ & 4 " & $\frac{1}{2}$ & 19 \\
\hline “ & 3 & $\frac{3}{16} 46$ & IO \\
\hline “ & I8 “ & $\frac{1}{2} \quad 6$ & 40 \\
\hline
\end{tabular}

The lack of uniformity in growth is of course due to the many and complicated problems of 


\section{A LABRADOR SPRING}

environment, for no two of these trees were exposed to exactly the same conditions of sunlight, wind, depth of snow, soil, amount of water, etc.

A larch that grew on the wind swept islands of Quatachoo, that was twenty inches tall and forty-five in extent, with a trunk one and one-half inches in diameter, had taken twenty years to grow. Another larch exposed to the winds of Esquimaux Island for one hundred and ten years had attained a height of three feet, a spread of eleven feet and trunk some two inches in diameter; and after all these years of struggle it was cut down by a traveller, but I trust its memory will long remain green. The only other larch I measured was a giant in a sheltered valley of an island of Quatachoo, and I scaled a steep rocky cliff by the shore and waded through a snow bank to my waist on the 29th of May to take his photograph. A robin and a white-throat sang in this sheltered valley while the surf thundered on the outer shore, and scuds of sea-fog drove over head, and in the stunted spruces close to the snow bank on the upper slopes a white-crowned sparrow, the aristocrat of his tribe, sang his 


\section{SOME LABRADOR TREES}

mournful song. The valley was picturesque in its rugged beauty and full of deep interest. This larch was the largest in a group of gnarled and twisted monarchs that must have defied the storms for many ages. He was still alive and the green buds of promise were appearing on his topmost boughs, which were fully thirty feet up in the air. At a distance of two and a half feet from the ground he measured six feet in circumference. How I should have enjoyed counting his rings, which must have numbered many hundreds, but even if it had been possible to cut him down and smooth off his stump it would have been indeed sacrilegious. May he live for many ages yet to come!

On this same island, however, I did steel my heart and cut down a splendid spreading mat of verdure, a balsam fir that had grown comparatively rapidly on a southern slope, but one that was so exposed to the gales from the gulf that it had reached a height of but three feet. One could walk over its compact top surface, which measured eighteen feet from side to side, but could not rest under the shadow of its branches unless one had been able to burrow 


\section{A LABRADOR SPRING}

into the ground like a fox, or flatten oneself out like paper. The trunk was four inches in diameter and contained sixty-seven rings.

A balsam fir fifteen feet high and two and one-half inches in diameter had grown rather rapidly for nineteen years, then very slowly for fifty-four years, and rapidly again for the last six. One might infer that its neighbours, starting at about the same time, so surpassed it when it was nineteen years old, that for over fifty years the lessened sun-light made its growth slow and painful, but that six years ago a storm had laid so many of its companions low that it plucked up heart in the renewed sunlight and grew like a sapling again, only to be slain in its lusty seventy-ninth year by man the destroyer. And for what purpose? To count its rings forsooth!

The stump of a favoured balsam fir at Esquimaux Point that I examined showed twentyone rings in a diameter of four and one-half inches. Its early life, however, had been rather difficult, for at the end of fifteen years it had reached a diameter of only an inch. Another balsam fir at Mingan had a diameter of trunk of eight inches, and had grown to be over thirty 214 


\section{SOME LABRADOR TREES}

feet in height in nearly a century, for I counted ninety-seven rings. Conditions were favourable for the first fifty years, but during the last forty-seven only a very little additional growth in girth was attained.

A black spruce at Esquimaux Island, growing with a multitude of others in close competition for sun and air, attained a height of ten feet and a diameter of trunk of two inches in fifty-six years. In its early youth, - its first forty years, - it reached a diameter of only five-eighths of an inch. Another black spruce on the same island, one that had to contend on the shore with the winds of the gulf, extended over six feet of ground, but grew to a height of only thirty-two inches. Its trunk was sturdy, three and three-quarters of an inch in diameter, and it contained seventy-seven rings. I counted two large black spruce stumps at Mingan; the first was in a thicket close to the tree containing the pigeon hawks' nest, and had been, if as tall as that tree, about forty-five feet high. There were I $2 \mathrm{I}$ rings in a circumference of thirty-nine inches, eighteen inches from the ground; about half the growth took place in the first forty years, after this progress was 


\section{A LABRADOR SPRING}

slow. The other tree was on the edge of the forest close to a marsh, where conditions for growth were so favourable that it had attained a diameter of fifty-eight inches in ninety-nine years.

A white spruce stump close to the house at Mingan with a circumference of seventy inches two feet from the ground had lived I 32 years; there were thirty-seven rings in the last inch. Another, a veteran, that had been cut down twenty inches from the ground on Mingan Island and left where it fell, had been fifty-five feet tall. Its stump sixty-five inches in circumference and eighteen inches in diameter was sound to the very centre, and showed 226 rings. Between its 50 th and $\mathrm{r} 80$ th years it had grown with uniform rapidity, as the rings were broad, but after that its growth was slow, and in the last three-fourths inch of its circumference it showed forty-six rings. If we suppose the tree had been cut down within a year, it must have begun life in the year ${ }_{1} 68_{3}$, or only three years after the founding of the Hudson's Bay Company.

The distinction between the three different species of spruces is at times confusing. The 216 


\section{SOME LABRADOR TREES}

thick, sturdy yellowish green needles of the red spruce, the slender, more delicate blueishblack foliage of the black spruce, and the handsome blue green branches of the white spruce are generally recognizable at a glance. One recognizes one's friends, however, not by noting that their eyes are black or blue, their noses are aquiline or otherwise, but by their general appearance, their distinctive air, by an intangible something one would be at a loss to define. I have known two brothers, one with black eyes, the other with blue, one with a beard, the other beardless, yet with a such strong family likeness to each other that they have been mistaken at a distance. The ornithologist often recognizes birds by little traits that are unknown to the beginner, who is slowly mastering the recognized field marks of the books. The former knows a blue-bird in the dusk when the blue back and the red breast look all of one colour. In the same way the master of the subject of trees can often tell at a glance the species, although he may not be conscious of the steps by which he arrived at his diagnosis. To an amateur this is a consummation devoutly to be hoped for, and in the 


\section{A LABRADOR SPRING}

case of the spruces, I am endeavouring to hasten the process of familiarity by planting one of each species within a few yards of my country house, so that I can watch them grow and become intimate with every stage in their progress. With the same idea I have planted what I have fondly called my forest where I have devoted an acre of land to New England trees only, - no foreign intruders are allowed. Here some fifty different species and many individuals are growing up. Only a few years ago one had to take care not to step on the forest in the grass, and my forest was the joke of my friends, but now the trees are rapidly extending above my head, and the birds of the air delight to lodge in their branches, for after all the birds are at the bottom of this scheme, but incidentally I am learning much of trees. Until one is perfectly familiar with the general habit, the intangible family air of the different species, it is a good plan to learn some special field marks. The long cones of the white spruce are of course distinctive. In the red and black spruces the cones look much alike, but in one species the cones generally fall off every year, in the other they persist for years. I have 218 


\section{SOME LABRADOR TREES}

been confused like the old lady and her indigo as to these cones until I invented the very simple mnemonic: black bind, red reject - their cones. Labrador trees could tell some very interesting stories if they could only talk, but they teach one lesson at least, that one cannot judge of age by size, - looks are indeed deceptive. 


\section{CHAPTER $\mathrm{X}$ \\ SOME LABRADOR RIVERS \\ "Les rivieres sont des chemins qui marchent."}

- Pascal.

THE Labrador Peninsula, like a mighty 1 sponge, holds much water in its meshes, frozen into flinty ice it is true during the greater part of the year, but abundantly fluid during the brief summer season. As one cruises along the southern coast line in spring, one passes a series of watercourses large and small, each bearing out into the green waters of the Gulf its dark brown floods laden with tree trunks and evergreen branches. Even at a distance of two or three miles from shore, the less dense fresh water is often distinct from the heavier sea-water which it overlays, and a curious effect is produced by the churning up of the green sea-water, so that it contrasts strongly in the steamer's wake with the tea coloured fresh water on either side.

All the rivers are frequented by trout and 220 


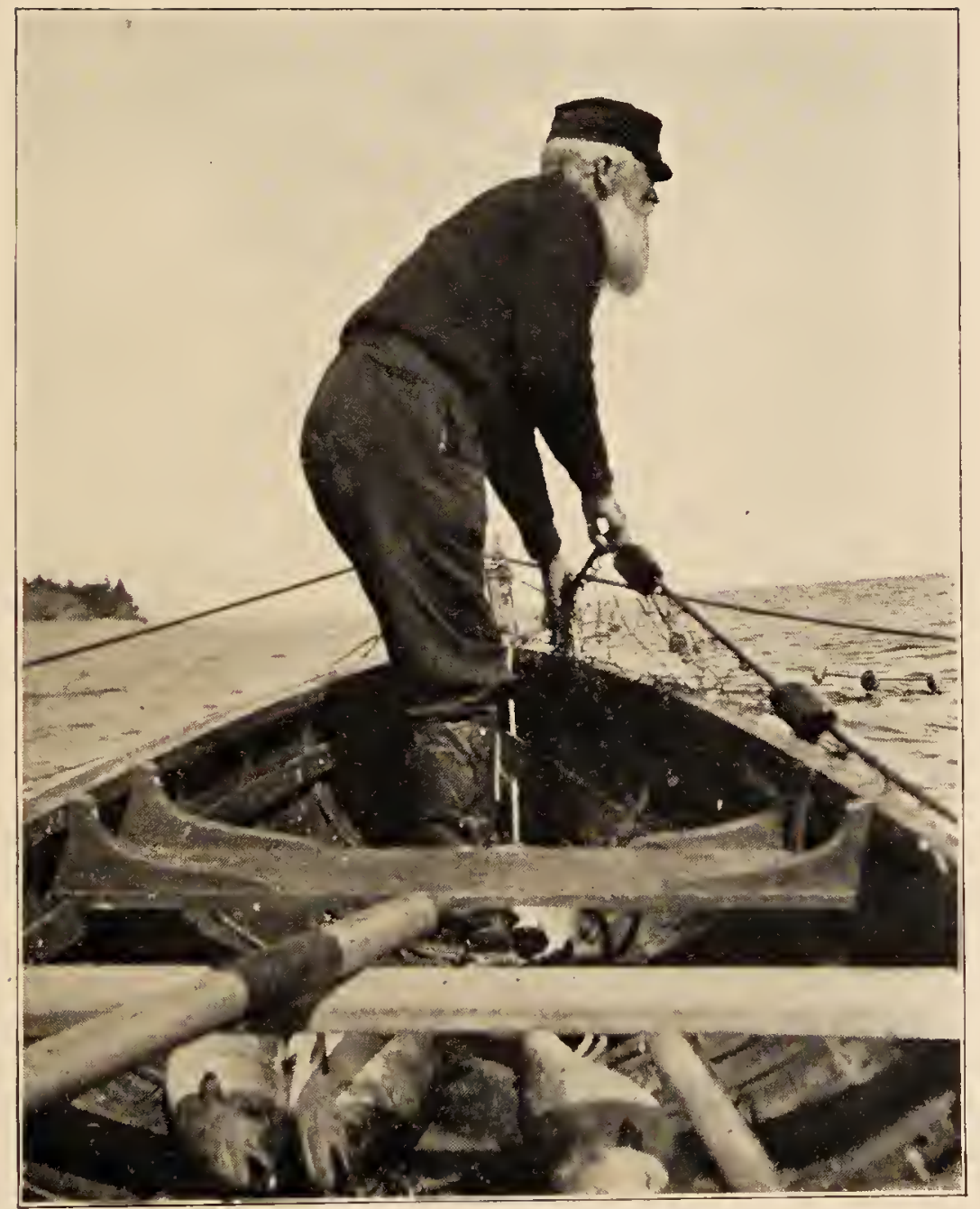

THE OLD SALMON-FISHER OF MINGAN TENDING HIS NETS. 



\section{SOME LABRADOR RIVERS}

nearly all by salmon, and although these southern rivers are leased by sportsmen for fly-fishing, the majority of the salmon are caught not for sport but as a business in nets. For some distance to the east of Seven Islands there is a salmon-net at every mile mark along the sandy shore. At the Moisie River a large salmon-fishery is in operation. At Mingan the Hudson's Bay Company sets several nets, the old salmon-fisher with whom we stayed had four or five more along the beach and at the island opposite, and two Gaspé men, camped at the mouth of the Mingan River, set six or seven more. Nets at the mouths of rivers are allowed if they do not extend more than one third of the way across. With all these nets to intercept the salmon on their way up the Mingan River to spawn it would seem as if few would escape, yet the owner of the river was just beginning his fly-fishing season as we left, and the fishing was generally good in the pools below the falls. We were told that at times the falls were black in places with the fish, tirelessly trying again and again to surmount them. We saw none there on June 2 rst - but it was still rather early in the season. 


\section{A LABRADOR SPRING}

Salmon were plentiful at the mouth of the river, however, and it was always interesting to watch the men take the splendid great fish out of the nets, and pack them in snow to await transportation by steamer to Quebec. The nets were generally supported by upright poles which extended out at right angles with the shore to a distance of two or three hundred yards. V-shaped trap nets were placed at intervals at right angles to the main net on the side from which the salmon came; the opening to the trap was on the shore side, as a bewildered fish always strikes out into deeper water when he fears capture. In their struggle to escape they are securely caught by the gills in the meshes of the net. Cartwright in his poetical epistle on Labrador says:

"The Salmon now no more in Ocean play, But up fresh Rivers take their silent way. For them, with nicest art, we fix the net; For them, the stream is carefully beset; Few fish escape: We toil both night and day. The Season's short, and Time flies swift away."

He spread his nets across the whole river!

Napoleon A. Comeau, the veteran naturalist and hunter of the north shore of the Gulf of St. 


\section{SOME LABRADOR RIVERS}

Lawrence, for forty-nine years guardian of the Godbout salmon river, has written several chapters on the salmon in a recent interesting book. ${ }^{\mathrm{I}}$ He says that these fish move in from the deeper waters of the gulf each year about the middle of May to the shores on both the north and south sides. To the west of Mingan the salmon follow the coast up the St. Lawrence River; at Mingan and below they follow the coast to the eastward. All are intent on entering the rivers to spawn, and this entrance begins about the Ioth of June and continues to the end of July. They remain in the estuaries of the rivers for some time before fighting their way up the swift current and through the rapids and falls of the rivers. The sites chosen for spawning, which takes place in September and October, are clear gravelly bottoms where the current is fairly swift. In the spring the salmon are in the best of condition, fat and silvery, but towards the end of October they are dark in colour and emaciated and the males show "a snout like a pig with an immense hook on the under jaw." "A

${ }^{1}$ Life and Sport on the North Shore of the Lower St. Lawrence and Gulf, Quebec, Igog. 


\section{A LABRADOR SPRING}

considerable proportion of the salmon that spawn early enough, - that is to say before the rivers freeze over, - return to the sea the same fall. But a very large number winter in the rivers and the lakes drained by them. These are the fish that come down the rivers in the spring as soon as the ice breaks up and until the spring freshets are over." These are called kelts or lingards. While the salmon in October are dark and emaciated, the kelts emerge in April with shining scales, a change which Comeau believes due to a process of moulting the old scales and reproduction of new ones.

The newly hatched fry are called parrs, which " pass into the smolt stage in their third and fourth year, going out of the rivers in August and September and sometimes in October." In October they range in weight from half a pound to a pound and a half. The next season they ascend the rivers in July, August and September under the name of grilse, weighing then three to five pounds, still small enough to run through the regulation salmon-nets with a mesh of five inches.

Rivers polluted by saw-mills or in other 224 


\section{SOME LABRADOR RIVERS}

ways are avoided by spawning salmon, while rivers, like the Manitou, with falls of such a size that the fish are unable to ascend them, although there is much good spawning ground above, are also avoided. Eventually these rivers will be treated as are similar rivers in Norway, where fish ladders are built enabling the fish to pass by the falls.

Comeau gives some interesting figures showing that contrary to the usual belief the catch of salmon has increased over thirty per cent. of late years. Thus the average yearly catch of salmon for the whole of the Province of Quebec for the years I 896, '97, '98 was 685,000 pounds, for 1906 , '०7, 'o8 over one million pounds. He also presents some records of fly-fishing on the St. John and Moisie Rivers. During the season of $187 \mathrm{I}$, five sportsmen between June $23 \mathrm{~d}$ and July I8th caught with the fly 416 salmon having a total weight of 4,755 lbs.; the largest fish weighed 26 lbs. In 1869 the result of 16 days' fishing with the fly by one man on the Moisie was 138 salmon weighing $2,4 \mathrm{I} 3 \mathrm{lbs}$., or an average of nearly I 7 I-2 lbs.; the largest fish weighed 37 lbs. In 187 I the records of three rods in the Moisie was 


\section{A LABRADOR SPRING}

325 fish weighing $5,789 \mathrm{I}-2$ lbs., a veraging about I 8 lbs. apiece; the largest fish in this case weighed $34 \mathrm{lbs}$.

During our stay at the old salmon-fisher's at Mingan we saw something of the river of this name, and we paddled up the three navigable miles of its course to where it emerges from the high land of the interior, and falls some thirty feet over the Laurentian rocks to the level of the sandy shore-plateau. Except for the large volume of water, for the setting in the dark forest and the background of the mysterious highland of the interior, these falls do not call for any especial mention. Below the falls the stream is one of considerable beauty, generally about a quarter of a mile wide, flowing through the elevated plateau by banks of windblown sand and spruce forests and bordered by alders and birches.

Just back of the Hudson's Bay Company's Post the river is rapidly wearing away the sand cliffs of the right bank, but, rebounding, it pursues a long S-curve to the sea. The character and extent of this curve is shown by the fact that by one path from behind the salmonfisher's house the distance to the river is about 


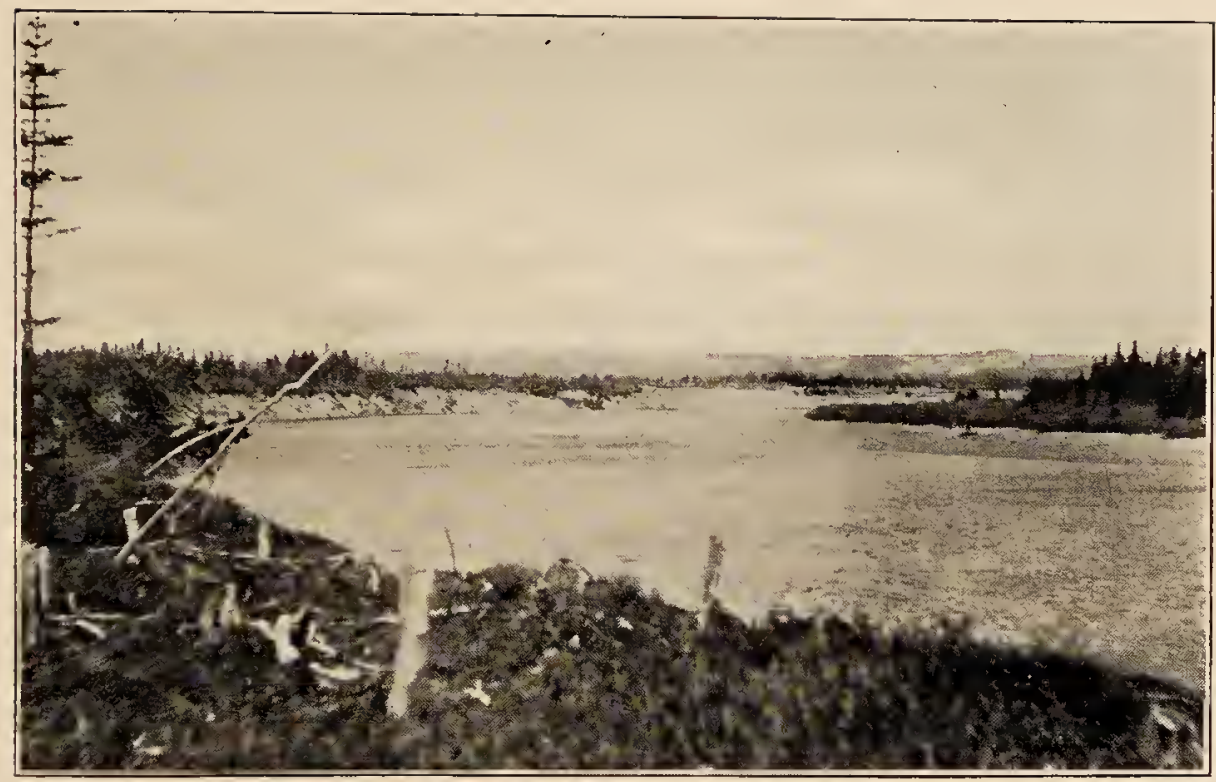

THE MINGAN RIVER BACK OF THE H. B. C. POST.

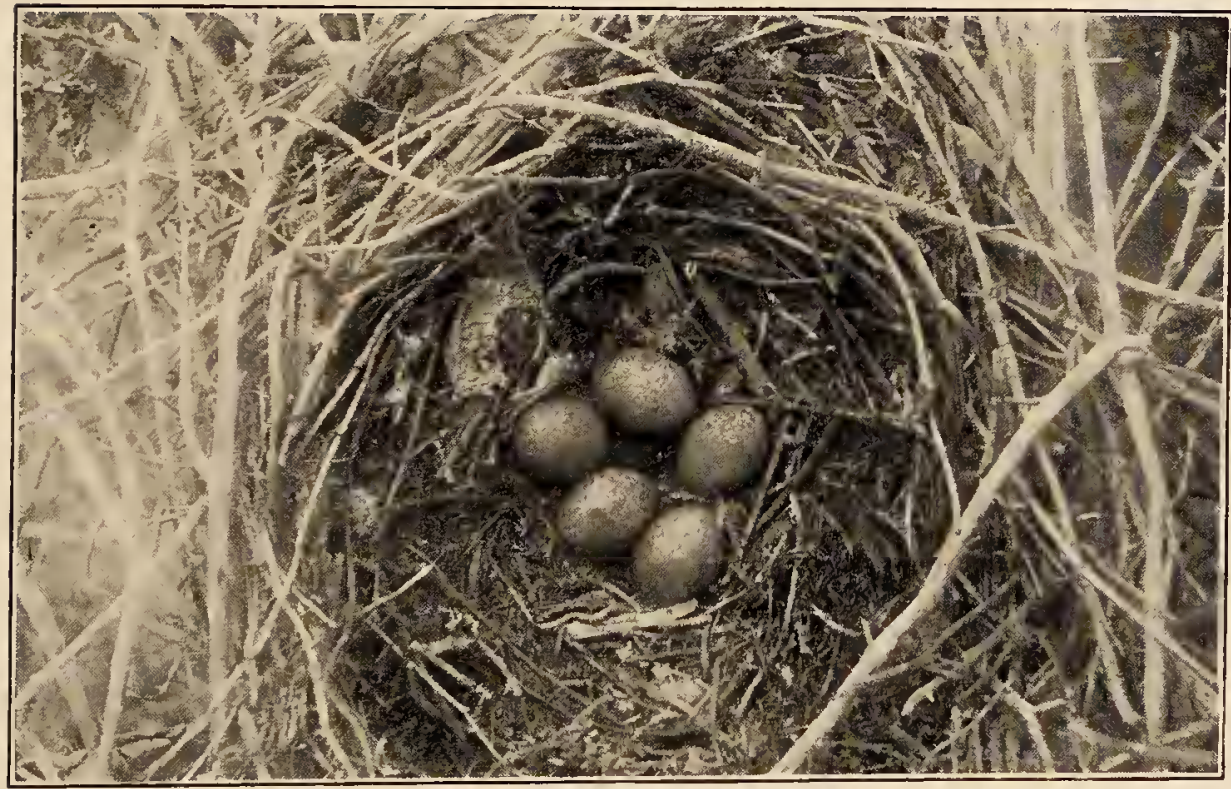

NEST OF THE PIGEON HAWK. 



\section{SOME LABRADOR RIVERS}

two hundred yards, by another, a straight path by the telegraph wires, the river lower down is reached at a distance of over a mile, while along the beach to the mouth of the river the distance is about three-fourths of a mile. The continual wearing back of the right bank by the impact of the river at the summit of the curve threatens the little settlement between it and the gulf, and it would not be difficult to calculate when the river will break through at this point, and wash the Honourable Hudson's Bay Company's Post into the sea.

We were casting our flies for trout one day from a sandy beach at the mouth of the Mingan River when two competitors appeared in the shape of a pair of seals, - loups marines,wolves of the sea the habitants call them, and indeed they are nearly right both from a biological and practical point of view. It was a pretty sight to watch their gambols, as with arched backs they would rush above the surface, and then disappear, or would throw themselves half out of water with a mighty splash in the excitement and enjoyment of the chase. I tried hard to see the trout in their jaws, but 


\section{A LABRADOR SPRING}

the seals were too quick for me. The fish immediately ceased striking, and evidently skulked in alarm. I was only too glad, therefore, on hearing the cries of a pigeon hawk, to lay down my rod and follow the bird until it plainly in its great anxiety pointed out its nest. This was situated about twenty-five feet from the ground in a tall black spruce, and was built of dry sticks and thickly lined with soft rootlets, small twigs and strips of soft bark, and it contained five thickly spotted, chocolate-brown eggs. Both parents flew about with rapidly quivering wings uttering their sharp vibrating ki ki ki; the voice of the smaller male was distinctly higher pitched and less harsh than that of his larger mate. From time to time they swooped down with great fury and swiftness at the intruder, but always glanced up before reaching him.

The Romaine River, one of the largest rivers of the southern part of the Labrador Peninsula, empties into the Gulf of St. Lawrence half way between Mingan and Esquimaux Point. At some distance from the coast it forms the most important highway into the interior, and is annually used by the majority of the Mon228 


\section{SOME LABRADOR RIVERS}

tagnais Indians. As the lower part of its course is interrupted by numerous rapids and falls, the Indians ascend the St. John River and portage, with aid of a series of lakes and small streams to the Romaine, where its waters flow more smoothly. Low, ${ }^{1}$ who has followed this route, says of the Romaine below the place at which the portage-route leaves it: "Nothing is known of the river for over fifty miles below this point, except that it is quite impassable for canoes, probably on account of long rapids with perpendicular rocky walls, where portages are impossible. Nothing but the absolute impossibility of passing up and down this part of the river would induce the Indians to make use of the present portageroute between the Romaine and St. John Rivers, which is the longest and worst of those known to the writer anywhere in north-eastern Canada. Careful inquiries from a score of Indians met coming inland afforded no information concerning this part of the river, which has never been descended by any one so far as known."

${ }^{1}$ A. P. Low, Geological Survey of Canada. Report on explorations in the Labrador Peninsula, Ottawa, I896, p. I70. 


\section{A LABRADOR SPRING}

This point in the Romaine River where the known leaves off and the unknown begins is about 75 miles in a straight line from the sea according to Low's map, or about roo miles by the river. The number of portages from the Romaine to the St. John River, according to Low, is thirty-one, " and their combined length aggregates nineteen miles and a half." The water part of this route between the two rivers, made up of lakcs and small streams, aggregates some forty miles in length. The difficulties of this long portage must be great, but it only serves to emphasize the fact that the lower course of the Romaine is impassable.

Cabot gives an interesting derivation for the name of this river, a derivation very different from the apparent one of Italian origin. He says: "Its Indian name 'Alimun,' meaning difficult, has passed through a rearrangement of sounds unusual in the adjusting of Indian names to French organs of speech. From 'L'Alimun' to 'La Romaine' the transition is easy, - surprisingly so, considering that no less a feat is involved than the introduction of the full rolling $r$ 230 


\section{SOME LABRADOR RIVERS}

into a language which has not the $r$-sound at all."

Although we caught a glimpse from the steamer of the Romaine River as it empties into the sea, our most satisfactory and interesting acquaintance with it was in the wilderness north of Esquimaux Point, for here the river flows from east to west parallel with the coast. Our search for the Romaine was made on July isth, a day on which many of the smaller birds had arrived, and winter was changing to summer, a day when the temperature climbed above $60^{\circ}$ at noon, although it registered only $48^{\circ}$ Far. morning and night.

The path from Esquimaux Point starts at the crucifix behind the village, and goes north through the spruce and balsam woods, - woods that were stunted by frequent cutting. We soon came to a bog, the familiar bog of Labrador, overflowing with moisture, a great sponge of sphagnum moss and reindeer lichen, interspersed with clumps of Labrador tea and laurel and alder, and with scattered larches and spruces, so dwarfed and prostrate as to scarce

${ }^{1}$ Labrador, by W. T. Grenfell and Others. New York, I909, p. 193 . 


\section{A LABRADOR SPRING}

rise above the moss. The botany of these bogs, plains or tundras, whatever one may choose to call them, always interested me and helped on in the difficult work of traversing them. Bog trotting, forsooth, - bog trudging, in truth, for when one sinks at every step nearly to the knee in the wet, elastic moss, one wishes for wings or perhaps snow-shoes. Audubon in a letter to his wife from this coast written July 23, I833, says: "Think of Mosses in which at every step you take you sink in up to your knees, soft as velvet, and as rich in colour." Over four of these bogs we passed, each larger than the last, and we crossed intervening ridges grown up to woods. In one place there was a bare, sandy ridge, the edge of a raised beach, but little changed since its elevation above sea level.

In the bogs were numerous ponds of all sizes from an acre to a square mile or two in extent. These ponds represent the contest between the force of water and of the growth of vegetation. It is evident that these plains were once the sea, and as the land rose and the sea was cut off they became great shallow fresh water lakes, around and in which the bog 


\section{SOME LABRADOR RIVERS}

growth was constantly pressing. Now some of the plains are filled with vegetation, in others the ponds remain with everywhere mossy and bushy edges, which are constantly striving to gain foot hold waterward. In places, especially on the sheltered sides, it is evident that vegetation is conquering the water, extending out in spots in floating islands over the surface. On the opposite side, exposed to the waves created by the strong, prevailing winds, the vegetation is in places undermined and falling in. That the bog will eventually win in this battle is only too evident. Then in turn the bog gives way to the evergreen forest gradually creeping in, the way paved by a growth of bushes which help to consolidate the spongy mass.

In one of the small ponds of a bog was a tiny islet, on which was a mass of goose down. Peer as we might we could not see the goose eggs that we were sure were concealed in this mass, and it was useless to attempt to wade or swim to the island, for the water, although clear on top and but a few inches to a few feet deep, was filled with flocculent peaty mud below of uncertain depth. However, a general photo- 


\section{A LABRADOR SPRING}

graph from a distance of the pond and islet and nest was taken, and this was sufficient to show the fact that Canada geese still nest near the southern Labrador coast. We saw eight or ten geese that day, some of whom honked cheerfully while others appeared to be nervous at our approach, and it was probable that more nests were concealed in the neighbourhood.

The last ridge we crossed that day was of considerable extent and thickly wooded, and, although threaded with several paths which were evidently used in winter wood cutting, there was no sign of a path over the extensive bog beyond. Hitherto we had been guided by an occasional stake, but here there were none. However, we determined to press on due north towards the rocky ridge of mountains which appeared no nearer than when we started, marking carefully the point where we left the woods, near some limestone cliffs that faced the inland sea of moss, just as the cliffs of Esquimaux Island face the tides that flow between them and the shore. Some time, if the upheaval still continues, Esquimaux Sound will be replaced by moss. 


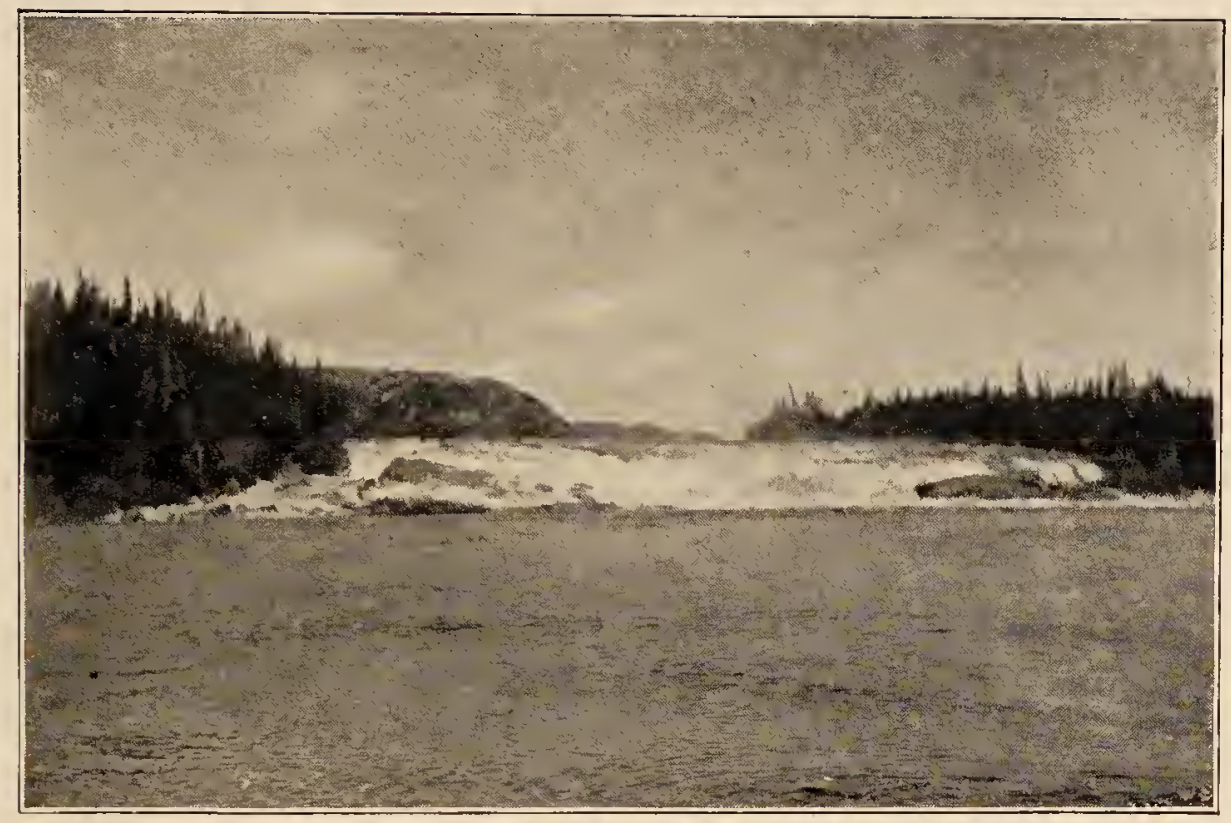

FALLS OF THE MINGAN.

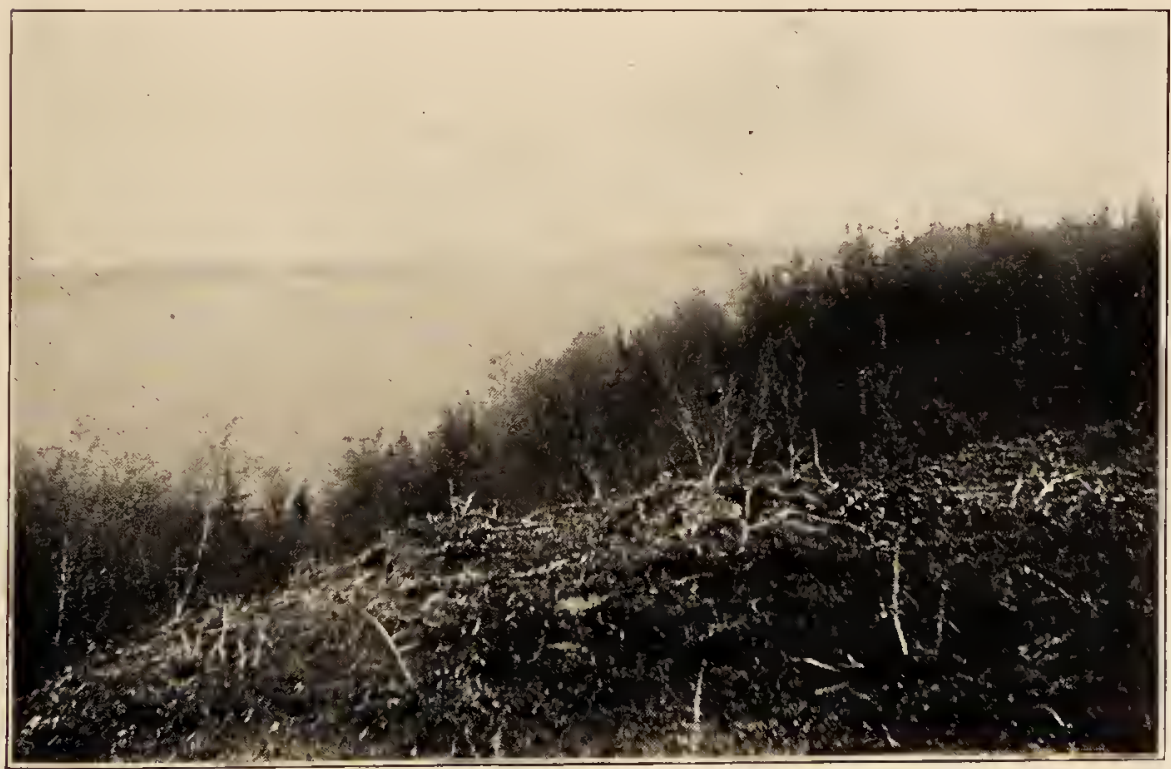

THE ROMAINE RIVER NORTH OF ESQUIMAUX POINT. 



\section{SOME LABRADOR RIVERS}

This was the most extensive bog of all, and although we were occasionally encouraged by dog signs which showed that we were going in the direction taken by the dog-sledges in winter, we had begun to be very sceptical as to the existence of the river at all, for we had trudged on for five hours, and we had been told that the river was only five miles off. These, however, were winter miles with a footing of ice and snow for fast-running dogs. Suddenly right before us, sweeping across our path was the river, and this view alone well repaid us for all our efforts. There was a sudden drop in the tundra, a big snowbank, a fringe of birches just leafing out in delicate green, and waving their yellow tassels of catkins to the breeze, a few spires of spruces almost black in comparison, and then, - but a stone's throw away, and forty or fifty feet below us, the mighty river, dark blue but flecked with whitecaps, flowing swiftly to the westward. Its breadth was about a third of a mile, and beyond stretched a great plain of dark green spruce forest, - the typical forest of the Hudsonian zone, dark, impenetrable, mysterious. A small winding branch stream entered the 


\section{A LABRADOR SPRING}

main river almost opposite. Beyond the forest plain was a wooded ridge of hills, and beyond this at a distance I could not even guess, was the eternal ridge, the foreguard of the rocky heights of the interior, a ridge blue and gray and white.

To the east there was a glorious view of the river flowing swiftly towards us for two or three miles, and issuing from the forest to the north. Here and there on either side of the river were low white sand-banks, their whiteness making a beautiful foil for the dark green spruces and blue water. Near at hand, on the south side of the river above the fringe of birches which skirted the edge, was a forest of tall gaunt spruces, a few giants standing out bare and leafless save for a tuft of dark green which crowned their summits. Below us to the west the river was parted by a wooded island, and the roar of the rapids on either side came to our ears like the surging of a mighty wind. Above the blue sky was flecked with fleecy clouds, and great cumuli were boiling up from the mountains in the north.

W'e climbed down over the snowbank into the wet, tangled forest below, but could not approach 236 


\section{SOME LABRADOR RIVERS}

the water on account of the thick fringe of alders, so we scaled again the bank, and found a warm sunny spot just below the edge, where, sheltered from the chilly wind which blew across the tundra, we could feast our eyes on the river to our heart's content. Close at our feet the snowbank still held many trees and bushes in its fetters. They were still leafless, while those below were clothed in the green of early summer. A larch near at hand, bent and twisted by the weight of many winters, had just emerged black and bare from the winter's blanket, yet it already showed on its topmost branches a promise of faint green buds. In the narrow valley below another larch hid its black branches under a green veil, and rejoiced in its strength. Near the snow drift the ground was naked, or brown and sere, while a few feet away it was clothed in the delicate green of young grasses and tender herbs. The bank above my head was blossoming with the white flowers of the cassandra, while the purple buds of the andromeda and the pale yellows once of the Labrador tea were just ready to open. In all three of these the leaves were fully out, for they are ever237 


\section{A LABRADOR SPRING}

green, and had remained from the previous summer.

A redstart, the "little torch" of the Cubans, and a magnolia warbler, gems of beauty which to the uninitiated would appear to be birds of the tropics only, were flitting about among the treetops, constantly expressing their love and joy of life in songs. That of the redstart was " sibilant and insistent," that of the magnolia warbler recalled the famous words veni, vidi, vici. A lonely loon was swimming in the surges below and then rose and flew into the dark forest beyond.

The snowbank, the soft, tender birches and larches, the mysterious, mighty river, the dark, trackless forest, the distant mountains, the shadowy high land of the north, the land of the ptarmigan, the caribou and the Indian, all made a picture I shall never forget. The spirit and the charm of wild beauty and mystery pervaded it all.

It was possible to enjoy all this ethereal beauty and mystery, and yet to be of the earth, earthy, and I hold that there is no shame in the latter, for we enjoyed a dinner of the best on this glorious day. After some erbsewurst soup, 238 


\section{SOME LABRADOR RIVERS}

hot in the frying-pan, a kindly provision of circumstances which forcibly, and at times painfully, checks too much haste, we were able to eat our cake as well as to keep it, for we partook of a Labrador spruce partridge whose skin we preserved as a specimen, and topped off - oh! ye gods - with what we were pleased to cali chocolate ice cream - a mixture of scraped sweet chocolate and snow.

As we returned over the tundra a sudden cold wind swept down on us from the north bearing with it a few drops of rain. Four geese flew low against the blast, and, setting their wings, alighted on the margin of a lakelet, where they kept up a continuous conversational honking. Two great black-backed gulls soared over head, and the roar of the river was intensified in the gusts. Gaining the first forested ridge, we looked back to the mocking mountains which appeared nearer than ever, as the north wind had cleared the atmosphere. As we approached our little village at the end of the day, we were so fortunate as to see a pair of marsh hawks, sailing over a bog, a bird that was recorded by Audubon from Labrador and by only one other observer, for Stearns obtained a specimen there 


\section{A LABRADOR SPRING}

nearly thirty years ago. Our expedition to the Romaine River was well worth while.

The Moisie River is an old Indian route into the interior, by way of an east branch of the Cold Water River, Lake Ashuanipi and the Ashuanipi River, Lake Petitskapau and the Grand River. It was the Moisie River that Henry Yule Hind ascended in I86I, and of which he published in 1863 a most interesting work in two volumes entitled: "Explorations in the Interior of the Labrador Peninsula, the Country of the Montagnais and Nasquapee Indians." Hind began the ascent of the river by canoes on June Ioth, I86I, and, after many difficulties and trying portages, reached on July 2 d, by way of the east branch, the height of land 2,240 feet above the sea, and over a hundred miles from it in a straight line. On his return he ran some of the six formidable rapids and, on reaching the mouth of the Moisie early in July, he says "we . . . took up our quarters under the hospitable roof of Mr. Holliday, the lessee of the Moisie Salmon Fishery," which is continued by the sons - who also own the line of mail steamers - to this day.

I was glad to see the mist of the mighty falls 


\section{SOME LABRADOR RIVERS}

of the Manitou River rising up in the dark forest as we steamed along the coast, even if I could not see the falls themselves, which are a mile and a half from the shore. The river is the third or fourth in magnitude on the coast, and the falls, which make a sheer descent of I 3 feet, must be of considerable grandeur and beauty. Hind relates that the "Manitou River takes its name from the following incident, which is often described in Montagnais wigwams to eager listeners never weary of repetition. About 200 years ago, when the Lower St. Lawrence was first visited by the Jesuits, the Montagnais were at war with the Souriquois or Micmacs of Acadia, who inhabited the south shore of the St. Lawrence and the country now called New Brunswick. A large party of Micmacs had crossed over the estuary of the St. Lawrence at its narrowest point and coasted towards Seven Islands, but not finding any Montagnais there, they descended during the night-time to the Moisie, and thence to the Manitou River, down which stream a few Montagnais bands were accustomed to come from the interior to the coast, to fish for salmon and seals. The Micmacs landed some miles before they reached the 241 


\section{A LABRADOR SPRING}

Manitou River, hid their canoes in the woods and stole towards the falls of the Manitou, to lie in ambush until the Montagnais should descend to the portage. The Montagnais knew their strength, and in the dim morning light began the fight at once, and after severe loss succeeded in killing or taking all but the leader of the Micmacs' band, a noted warrior and conjuror, and one whom the Montagnais were most anxious to take alive. Finding escape hopeless, he sprang to the edge of the cataract, and, crouching behind a rock, began to sing a defiant war-song, occasionally sending an arrow with fatal effect at those who were bold enough to show themselves. The Montagnais, sure of their prey, contented themselves with singing their songs of triumph. The Micmac chief and conjuror suddenly jumped upon the rock behind which he was hidden, and ap. proached the Montagnais, telling them to shoot. But the Montagnais wanted their prisoner alive, so they let their arrows rest. The conjuror next threw away his bows and arrows, and invited them to come and attack him with their knives. The Montagnais chief, anxious to display his courage, rose from his conceal- 


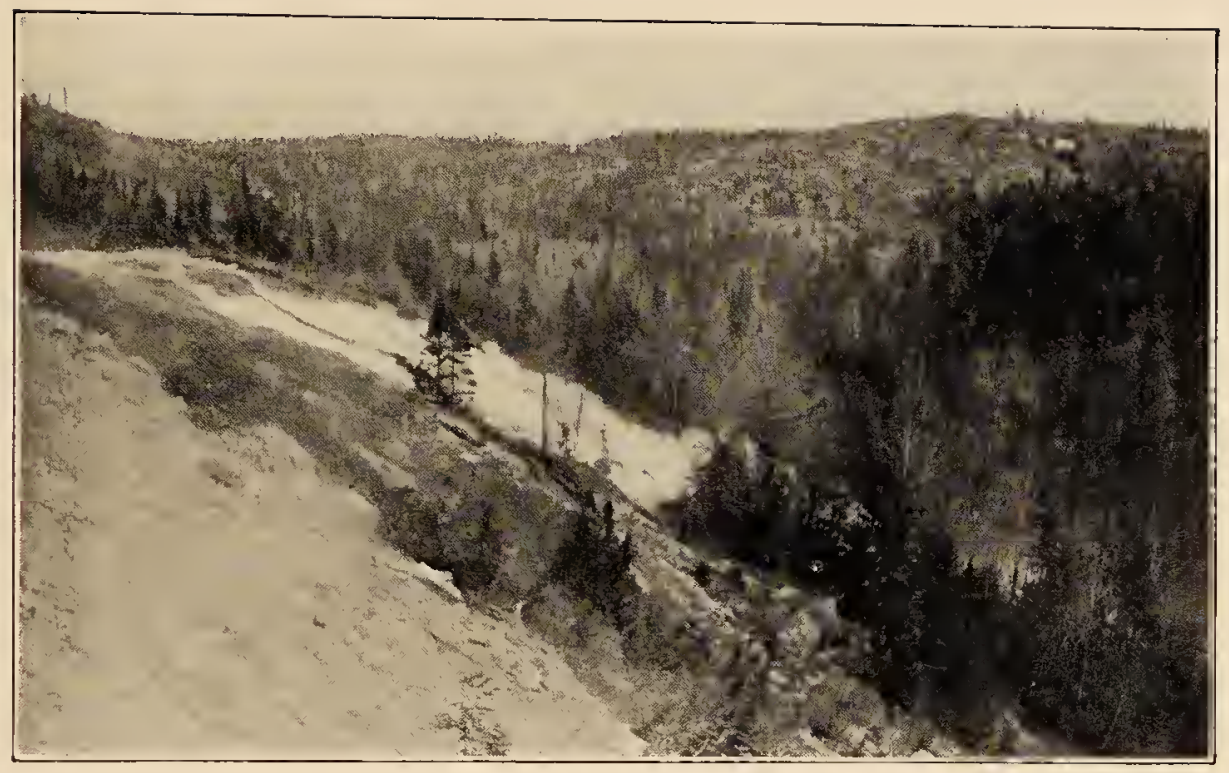

FALLS OF PIASHTE-BAI RIVER.

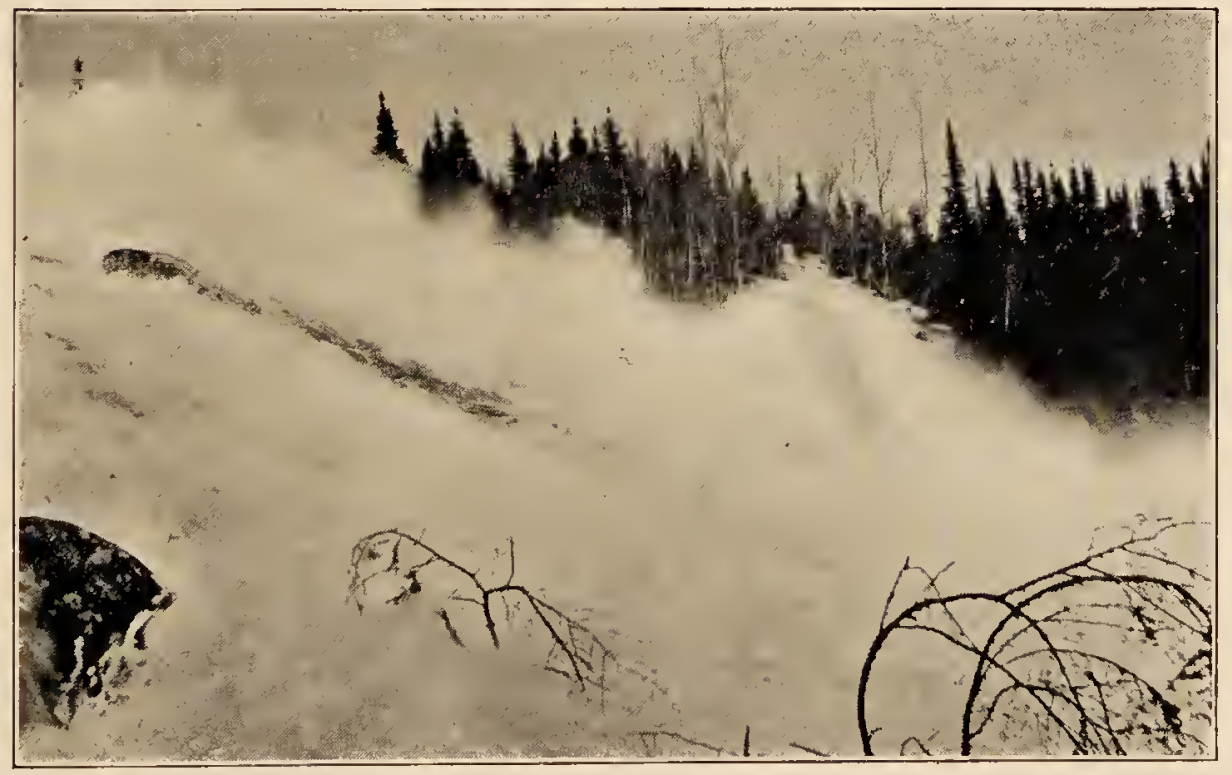

NEAR THE FOOT OF THE FALLS. 



\section{SOME LABRADOR RIVERS}

ment, knife in hand, and, throwing away his bow and arrows, sprang towards the Micmac, who, to the amazement of all beholders, retreated towards the edge of the rock overhanging the falls, thus drawing his enemy on, when, with sudden spring, he locked him in a fatal embrace, and, struggling towards the edge of the precipice, leaped with a shout of triumph into the foaming waters, and was instantly swept away over the tremendous cataract, which has since borne the name of the conjuror's or the Manitousin Falls."

On the 28th of May we paddled and rowed in a modified or " evolved" canoe up the Piashtebai River. A mile from the bay brought us to a considerable expansion of the river, and, had it not been for our guide, we might have spent many hours in searching the shores of this lake for the continuation of the river above. As it was we were shown the river where we least expected it, flowing for a mile through a drowned muskeg, and then emerging from the forest with rapid course. The swift current finally prevented further progress, and, landing on the right bank near an old bear trap, we followed through the thick spruce woods an Indian 243 


\section{A LABRADOR SPRING}

portage path that soon began to ascend the rocky barren hills we had seen before us. This path ends on the high land at a small lake from which the river discharges, and throws itself in a broken fall of great beauty down a hundred and fifty feet or more into the forest below. Although the falls are not a sheer descent, but form an angle of about forty-five degrees, the effect is grand, as the great volumes of white waters come bounding down the decline, appearing to burst and throw themselves thirty or forty feet into the air in their progress. The setting in the wild forest added much to the beauty of the scene, for, with the exception of the faintly marked Indian portage-path, there was no sign of man to be found, - there was no park, no " path to view the falls." By gradually working my way through the thick spruces and birches that grew luxuriantly in the constant spray, I managed to reach a point of advantage at the foot of the falls. Both the air and the fallen tree on which I stood were quivering and throbbing with the pulse-beat of the cataract, which roared loudly in my ears, and the trees swayed with the force of the blasts of air and spray. The leaping, spouting waters, 


\section{SOME LABRADOR RIVERS}

plunging down with a front of over a hundred feet, contract to half this width at the foot and take an abrupt turn to the right to form the rapids and whirlpools below.

All the rivers were not large, and we spent many happy hours bird-watching and exploring in the neighbourhood of an attractive stream near Esquimaux Point. Inquiring of our good friend the government doctor stationed at this village as to its name, for the stream was not noticed on the chart, he modestly confessed that the villagers called it La Rivière $d u$ Docteur, because he kept a canoe on it in. summer above the rapids, and fished it for trout. As we frequently dined on its bank we occasionally cast a fly, but the waters were still too cold with melting snow, and we never beguiled a trout from them into the pan. I can testify not only to the coldness of its waters, but also to the swiftness of its current and the sharpness of its limestone bed, for interesting birds had an annoying habit of flying to the opposite bank. My companion, more thoughtful than I, had provided himself with hip rubber boots, but he generously paid the penalty by acting the part of the old man of the sea, on 


\section{A LABRADOR SPRING}

the rare occasions when we did not lose each other.

Perhaps the most frequent and certainly the most prominent bird song heard near this river was that of the fox sparrow. Its wonderfully clear flute-like notes came forth from the spruces at all times of day, delivered with a great precision, and with a mastery of technique that can scarcely be rivalled in the bird chorus. One who has heard only the imperfect songs of this bird in its brief passage through the eastern States, and before the ecstasy of its passion has been attained, can not realize the intensity and scope of its love utterances in its breeding home. It was a song that one could not but admire for the beauty and richness of its performance, but at the same time one felt that it lacked the charm, the soul, the spirituality or whatever one may call it that applies so forcibly to the divine song of the hermit thrush or the simpler melody of the whitethroated sparrow, songs of which one never tires.

Sometimes the brightest gems are buried in obscure and unexpected places. In one of the scientific publications of the Boston Society 


\section{SOME LABRADOR RIVERS}

of Natural History for the year $188_{3}$, the following by Mr. William Brewster, who paid a flying visit to southern Labrador in I88I, more clearly expresses these thoughts, and well describes the song of the fox sparrow and its settings: "What the Mocking-bird is to the South, the Meadow Lark to the plains of the West, the Robin and Song Sparrow to Massachusetts, and the White-throated Sparrow to northern New England, the Fox Sparrow is to the bleak regions bordering the Gulf of St. Lawrence. At all hours of the day, in every kind of weather late into the brief summer, its voice rises among the evergreen woods filling the air with quivering, delicious melody, which at length dies softly, mingling with the soughing of the wind in the spruces, or drowned by the muffled roar of the surf beating against neighbouring cliffs. To my ear the prominent characteristic of its voice is richness. It expresses careless joy and exultant masculine vigour, rather than delicate shades of sentiment, and on this account is perhaps of a lower order than the pure, passionless hymn of the Hermit Thrush; but it is such a fervent, sensuous and withal perfectlyrounded carol that it affects the ear much as 


\section{A LABRADOR SPRING}

sweet-meats do the palate, and for the moment renders all other bird music dull and uninteresting by comparison."

Another small stream, yet of considerable size, was one whose distant roaring added to the charms of the little protected harbour among the Isles des Corneilles, where we had cast anchor. This stream, this River of the Crow, for such I suppose was its name, gave me but a glimpse of its rushing, turbid waters as it came pouring down through the spruce forest, whose melting snows were silently adding to its volume. From these dark and tangled evergreen thickets not only here but also along the whole coast, a wonderfully varied and delightful bird-song would emerge at frequent intervals and at all times of day. Like most of the inhabitants of this coast the bird spoke French, and, with great clearness and insistence, it would frequently and repeatedly call tout de suite. At least so it seemed to me, but perhaps it was because of my recently acquired sensitiveness to the French language, for in Newfoundland and other English-speaking countries I had never noticed this French phrase. It would also say loudly and clearly 


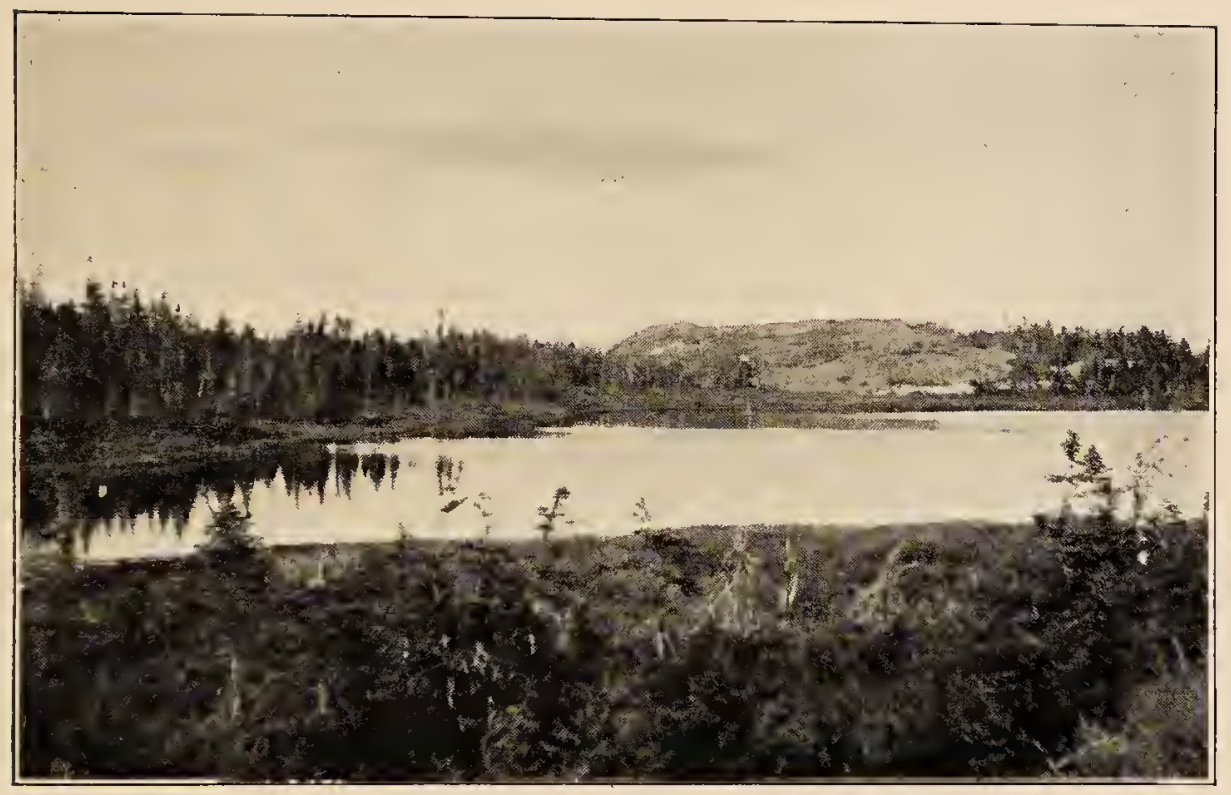

BOG ENCROACHING ON POOL AND FOREST ENCROACHING ON BOG.

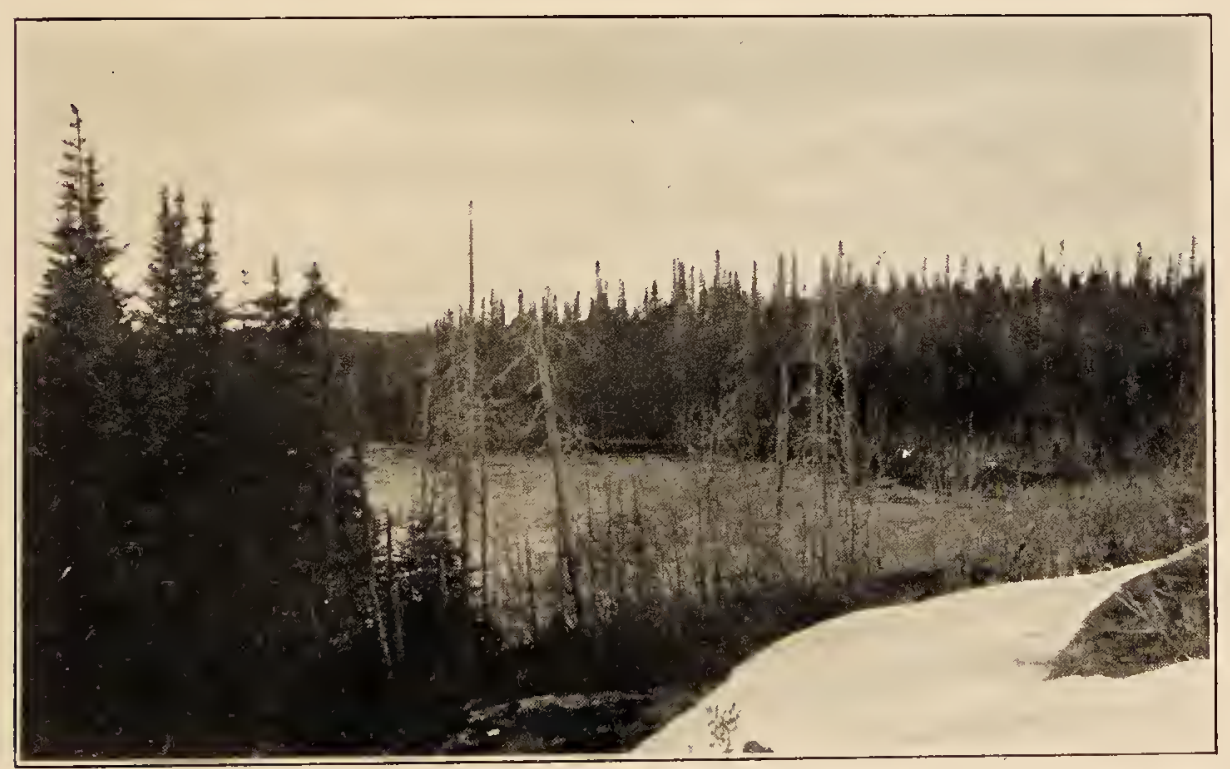

SPRUCE FOREST, SNOW-BANK AND THE RIVER OF THE CROW. 



\section{SOME LABRADOR RIVERS}

pop-a-teet, sweet sweet, or repeat the sweet, sweet continuously for minutes at a time. These and many other notes were but the preludes or interludes to the real song which varied with the singer or his mood, but, in what I deemed its classical form, consisted of three parts: the first faint and lisping, suggestive of the black and white warbler; the second clear and flutelike recalling some of the notes of the robin, while the third part, the climax, is a wonderful succession of delightfully musical triplets with rising inflection. One might imagine that not one, but several birds were thus performing, or if there were but one performer, he would be at least as large as a bullfinch. This wonderful singer, the ruby-crowned kinglet, is, however, about the bigness of one's thumb, and how he manages to get so much melody out of his little frame, or so much inspiration from a wilderness, is to me an unexplained mystery.

While the eastern Labrador coast is conspicuous for its rocky headlands, its deep harbours and narrow fiords, this portion of the southern coast is equally conspicuous for its long reaches of sandy shores, its coastal plain and its barrier : sountain range, and while the drainage on the 


\section{A LABRADOR SPRING}

eastern coast concentrates the chief part of its floods at one point, the Grand River in Hamilton Inlet, the southern coast is remarkable for the number and size of its rivers, which pour out at frequent intervals along the shore. These rivers are, with but trifling exceptions, still unknown by the white man except at their mouths where they are leased for salmon-fishing, and, although they lie at our doors, their opportunities for exploration and adventure still remain unheeded.

THE END 


\section{Index}

Note. - The scientific names of the birds and plants are given after their common names.

Acadia, 64.

Acadians, 64, 65 .

Acadians, Religion of, 73-8I.

Agriculture, 70, $7 \mathrm{I}$.

Alder, Speckled (Alnus incana), I3, I8, 237.

Andromeda (Andromeda glaucophilla), I6, 237.

Aspen (Populus tremuloides), 46.

Audubon, 26, 125, 129, 232, 239.

Auk, Razor-billed (Alca torda), 58, I28.

Avens, Mountain (Dryas integrifolia), 22.

Bake-apple, see Cloudberry.

Balsam Fir (Abies balsamea), 15, I9, 210, 213-215.

Barge, I05, I65.

Battle Harbour, 52.

Bay, Piashte-bai, II5, II7.

Bay of Seven Islands, 37.

Bay, Yellow, I2I.

Bay, Washtawooka, I23.

Bearberry (Arctostaphylos Uva-ursi and A. alpina), I7.

Beaver, II5, I16, I67. 


\section{INDEX}

Bendire, Charles, Ior.

Betchewun, II I.

Billiards, 143, I44.

Birch, Canoe (Betula alba), I4, I9, 37, 46, 235.

Bird Song, Evolution of, 27.

Bissot, Sieur de la Rivière, 4I, I72.

Blanche, Monseigneur Gustave, 77.

Bluebird (Sialia sialis), I2.

Bog, 15, 24, 48, 63, 209, 210, 23I-233.

Bonnycastle, Sir Richard, 96.

Boudrot, Ferman, 65.

Boulders, Glacial, see Erratics.

Brant (Branta bernicla), 38, 39.

Brass bracelet, II 5 .

Brewster, William, 98, 247.

Burgomaster, see Gull, Glaucous.

Burrows of puffin, I27.

Cabot, John and Sebastian, 40, 4I.

Cabot, W. B., I50, I6I, 230.

Calli on trees, 19.

Canoe, Indian, 104, I20, 165.

Cartier, Jacques, 39, 40, I 52.

Cartwright, Capt. George, I3, 32, I30, I31, I 52, 222.

Cartwrights, Three modern, I30-I48.

Cassandra (Chamaedaphne calyculata), I6, 237.

Catlin, George, I76.

Cats, I62, I63, I65.

Church of St. Peter, 69, 74-76.

Clark City, 38.

Cloudberry (Rubus Chamaemorus), II, 26, 49.

Coastal plain, 49, I23, 226.

Collins, Robin Company, 54. 


\section{INDEX}

Cod, 7I, 73.

Comeau, N. A., 222-226.

Cook, Capt., 4I.

Cormorant, Double-crested (Phalacrocorax auritus), IIII I3, II 7 , I I8.

Cornel, Dwarf (Cornus canadensis), I6, 49.

Corpus Christi, Feast of, 78-8I.

Corte-Real, Gaspar, 4I.

Courtship of black duck, 95, 96 .

Courtship of eider, $84-89$.

Courtship of golden-eye, 89-95.

Courtship of some Labrador birds, 83-I03.

Courtship of ruffed grouse, $98,99$.

Courtship of spruce partridge, I00, гог.

Courtship of ptarmigan, 99, Ioo.

Courtship of puffin, 96, 97.

Cow parsnip (Heracleum lanatum), I4, 20, I27.

Crêpes, I24.

Currant (Ribes triste, also $R$. prostratum and gooseberry, $R$. oxycanthoides), $13,20$.

Dogs, Eskimo, I34.

Dogs, Indian, I63.

Dress of Indians, see Indians, dress of.

Dress of French inhabitants, 43, 7I, 75.

Duck, Barrow's golden-eye (Clangula islandicus), 94, I4I.

Duck, Black (Anas rubripes), 95, I32.

Duck, Eider (Somateria dresseri), 63, 84-89, I07, I I4, I 59.

Duck, Harlequin (Histrionicus histrionicus), i 19.

Duck, Long-tailed (Harelda hyemalis), 52, 53.

Duck, Golden-eye (Clangula clangula americana), 89-95.

Eel-grass (Zostera marina), 38.

Egging and eggers, 159. 


\section{INDEX}

Eider, see Duck, Eider.

Eider-down, 159.

Elevation of the land, 109, I23, 232.

Erratics, Glacial, 47.

Eskimos, I5I, I52.

Esquimaux Point, 13, 65-82.

Eudist fathers, 77 .

Falls of the Manitou River, 240-243.

Falls of the Mingan River, 226.

Falls of the Piashte-bai River, 244, 245.

Falls of the Rivière Blanche, 53.

Ferland, Abbé, 8I.

Fires, Forest, 46, 149, 168.

Fishermen, 67, 73, 74 .

Fish-flakes, 54.

Fishing boats, 42, 54, 72, 73 .

Flies, 32.

Flight song, 49.

Flycatcher, Least (Empidonax minimus), 27.

Flycatcher, Yellow-bellied (Empidonax flaviventris), 26-30, 32.

Foxes, Black, Breeding of, 136-140.

Frazar, M. Abbott, 125.

Fur-trader, 115, I69, I72.

Gannet (Sula bassana), 54, 58, 59 .

Gaspé, 37.

Gilbert, Sir Humphrey, 39.

Glacial phenomena, 37, 47, 48, 6r.

Goldthread (Coptis trifolia), 16, 20.

Goose, Canada (Branta canadensis), 114, 234, 239.

Granitic rocks, 37, 49, 118 .

Grenfell, Dr. W. T., 68, 106, 126. 


\section{INDEX}

Grilse, 224.

Guillemot, Black (Cephus grylle), 62.

Gulf of St. Lawrence, 36.

Gull, Glaucous (Larus glaucus), 51.

Gull, Great black-backed (Larus marinus), 63, I09-III, 239.

Hakluyt, 33, 39.

Harrington, I26.

Hâvre des Sauvages, I22.

Hawk, Marsh (Circus hudsonicus), 239.

Hawk, Pigeon (Falco columbarius), 228.

Hearn, Capt., I26.

Hind, Henry Yule, 44, I49, I50, I66, I67, I76, 240.

Holliday Brothers, 50, 240.

Horned Lark (Otocoris alpestris), 45.

Hubbard, Mrs. Leonidas, I 50.

Hudson's Bay Company, 42, 59, I67, I70-175, 216.

Hylas, 17.

Ice, 24,25 .

Indians, Algonquin, I5I.

Indians, Diseases of, I77-179.

Indians, Dress of, I55-157, 163, I64.

Indians, Dwellings of, I57, I58, 177.

Indians, Iroquois, I 5I, I52.

Indians, Migration of, $\mathbf{1 6 6 .}$

Indians, Montagnais, 149-179, 229, 24I-243.

Indians, Nascaupee, I5 I, 167.

Indians, Religion of, I60, I6I, I65.

Indian Trading House, I74, $\mathbf{1 7 5}$.

Island of Anticosti, 49 .

Island, Bald, I27, I 28. 


\section{INDEX}

Island, Charles, ro8.

Islands of the Crow, see Isles des Corneilles.

Island, Esquimaux, 17, 21, 61-63, 108.

Island, Faux Pas, Iog.

Islands, Perroquets, 58.

Island, Hunting, 108, III.

Island, Little St. Charles, I28.

Islands, Mingan, 59.

Island, St. Genevieve, 60.

Island, Sea-cow, ro8.

Isles des Corneilles, I I4, I53.

Jay, Blue (Cyanocitta cristata), I4I.

Jolliet, Louis, $4 \mathrm{I}$.

Junco (Junco hyemalis), 30.

Juniper (Juniperus communis var. depressa and J. horizontalis), I5.

Kelt, 224.

Kinglet, Ruby-crowned (Regulus calendula), 30, 248, 249.

Kingbird (Tyranus tyranus), 26.

Kneeling posture, I20, I57.

La Belle Marguerite, Cruise of, I03-129.

Labrador Company, I72.

Labrador Fur-trading Co., I24.

Labrador Peninsula, Definition of, 36 .

Labrador Tea (Ledum groenlandicum), I I, I6, 231, 237.

Language, French, 43, 65-67.

Language, Indian, 170.

Larch (Larix laricina), 14, 19, 210-213, 237.

Lark, Horned, see Horned Lark.

Laurel (Kalmia polifolia and K. angustifolia), I6, 48, 23 I. 


\section{INDEX}

Legs in traps, 133.

Lichens, I5, 46, 47.

Limestone, I7, 22, 60, 61, 62, 234.

Lobsters, II3, I22, I37.

Long Point, 58.

Loon (Gavia immer), 5.1. 52, 162, 238.

Loss of hair, Story of, I24, I25.

Low, A. P., 44, 49, I50, I5I, 229.

Lucas, F. A., 59.

Margot, sce Gannet.

Marigold, Marsh (Caltha palustris), 20.

Martial, I04, 105, I06, I20.

Maryland yellow-throat (Geothlypis trichas), 3I.

Mathias, 104, I05, 107, II5, I2I.

Mica mine, I 7 .

Mills, Enos A., 206.

Mingan, 59, I70.

Mingan, Seigniory of, 4I, I7I, I72.

Modern bird-study, I86-I88.

Moisie, 50.

Mosquitoes, 32, 33.

Mountains, 38, 43-50, 234, 236.

Mountain Ash (Pyrus americana), I4, 20.

Mount St. John, 44, 58.

Murre (Uria troille), I32.

Musquarro, I60, І6г.

Natashquan, 20, I23, 124.

Nest of Canada goose, 233, 234 .

Nest and eggs of double-crested cormorant, I I2, I I3.

Nest and eggs of eider, II 4 .

Nest and eggs of golden-eye, 90 . 


\section{INDEX}

Nest and eggs of great black-backed gull, I09, I IO.

Nest and eggs of spruce partridge, I29.

Nest and eggs of pigeon hawk, 228 .

Nest and eggs of puffin, I27.

Old Squaw, see Duck, Long-tailed.

Omelet, II6, I17.

Orchid, Calypso (Calypso bulbosa), 21.

Ox, Magpie, 54-57.

Parr, 224.

Partridge, Hudsonian spruce (Canachites canadensis), I00, IOI, I29.

Pashasheeboo, I22.

Perroquet, see Puffin.

Phalarope, Northern (Lobipes lobatus), rog.

Pipit (Anthus rubescens), 30, 45.

Pitcher-plant (Sarracenia purpurea), I5.

Plongeur, see Duck, Golden-eye.

Plover, Piping (Agialitis meloda), 125 .

Porcupine, I67, 168.

Priests, 76-80, І25, І60, І61.

Primrose, Mealy (Primula farinosa var. incana), 22.

Protection to nesting birds, 159.

Ptarmigan, willow (Lagopus lagopus), 45, I41, I67.

Puffin (Fratercula arctica), 58, 96, 97, 127, 128.

Purple finch (Carpodacus purpureus), 49.

Quatachoo, II8.

Raquettes, sec Snow-shoes.

Raspberry, Arctic (Rubus arcticus), 30.

Raven (Corvus corax principalis), 62. 


\section{INDEX}

Red-osier (Cornus stolonifera), I4, 20.

Redstart (Sctophaga ruticilla), I8, 2I, 3I, 238.

Refrigerating plant, I4I.

Rhodora (Rhodora canadense), 48.

Richelieu, Cardinal, ı

River, Agwanus, I22.

River, Crow or Corneille, II3, 248.

River, Grand or Hamilton, 46, I 50.

River, Grand or Sandy, 53.

River, Little Natashquan, I23, I24.

River, Magpie, 54.

River, Manitou, 225, 240-243.

River, Mingan, 30, 45, 221, 226, 227.

River, Moisie, 50, I66, 225, 240.

River, Nabesippi, I22.

River, Natashquan, I25, I60, 166.

River, Piashte-bai, 243-245.

River, Romaine, I8, 24, I21, I66, 228-240.

River, St. Marguerite, 37, I66.

River, St. John, I5I, I66, 225, 229.

River, St. Lawrence, 37.

River, Shelldrake, 54.

River, Thunder, 54.

Rivers, Some Labrador, 220-250.

Rivière Blanche, 53.

Rivière Du Docteur, 245, 246.

Robes noirs, Les, see Priests.

Robin (Planesticus migratorius), I4, 30, I07.

Ross, Dr., 42.

Ruffed grouse, Drumming of, 98,99 .

Sails, Dyed, I05.

Saint Cuthbert, 159. 


\section{INDEX}

Salmon, 50, 22I-226.

Salmon-fisher's house, II3, I70.

Salmon, Migration of, 223-225.

Salmon Nets, 221, 222, 224.

Salmon, Yearly catch of, 225 .

Sand dunes, I25, I26, I62.

Sandpiper, Spotted (Actitis macularia), I07.

Saxifrage, Mountain (Saxifraga oppositifolia), I7.

Scoter, Surf (Oidemia perspicillata), 193.

Sea-birds, Extermination of, I58-160.

Sea-pigeon, see Guillemot, Black.

Seals, I23, I34, 227.

Selous, Edmund, 97, I93, 195, 196.

Seal Rock, II I.

Seven Islands, 36, 42.

Sexual selection, 89, 97 .

Shechootai, see Cloud-berry.

Skunk cabbage (Symplocarpus foetidus), I2.

Sleeping-bag, I07.

Smolt, 224.

Snow, II, I4, I9, 2I, 23, 30, 50, II4, 235, 237.

Snowberry (Chiogenes hispidula), I6.

Snow bunting (Plectrophenax nivalis), 14, 30, 132.

Snow-shaes, I73.

Sparrow, Fox (Passerella iliaca), I4, 30, 80, I07, II4, 246248.

Sparrow, Lincoln's (Melospiza lincolni), I4, 32.

Sparrow, Tree (Spizella monticola), II4.

Sparrow, White-crowned (Zonotrichia leucophrys), I4, I I4.

Sparrow, White-throated (Zonotrichia albicollis), I4, 30, I07, I I4, I32.

Sphagnum, I5, 25, 23I.

Spring, A Labrador, II-35. 


\section{INDEX}

Spruce, Black (Picea mariana), I5, 210, 215, 216, 217.

Spruce, Red (Picea rubra), 15, 217.

Spruce, White (Picea canadensis), I5, I24, 216, 217.

Stearns, W. A., 239.

Strathcona, Lord, 74.

Sun-baths, 35 .

Submersion of the land, 48, 49.

Swallow, Bank (Riparia riparia), I08, rog.

Swallow, Tree (Iridoprocne bicolor), I62.

Temperature, 24, 26, 34 .

Tern, Caspian (Sterna caspia), I25.

Tern, Common (Sterna hirundo), I22.

Thayer, A. H., on Concealing-coloration, 89.

Thrush, Hermit (Hylocichla guttata pallasii), 30, 80, I32.

Tickle, 50, I2I.

Toads, Trilling of, 17 , I8.

Traps, 133, 243.

Trees, Some Labrador, 206-2rg.

Tremblay, Dr. J. E., I04.

Trout, 220, 227.

Tundra, see Bog.

Turner, L. M., 99.

Village, An Acadian, 64-82.

Violet, White (Viola incognita), 20.

Wallace, Dillon, 150.

Walrus, 4I, I08.

Warbler, Black-poll (Dendroica striata), 30, $3 \mathrm{I}$.

Warbler, Magnolia (Dendroica magnolia), 2I, 3I, 238.

Warbler, Nashville (Vermivora rubricapilla), 3I.

Warbler, Wilson's (Wilsonia pusilla), 3r, 49. 


\section{INDEX}

Watcheeshoo, II 9.

Whale Factory, 38 .

Whales, 50, $5^{\text {I. }}$

Wilson, J. A., 46, I49, I79.

Whitbourne, 33 .

Willow (Salix groenlandica, S. vestita, S. anglorum, $S$. candida), II, 20.

Wing, Bastard, Use of, I88, I89.

Wings and feet in the air and under water, I80-205.

Wood pewee (Myiochanes virens), 26.

Wood-pulp, 38 .

Wren, Winter (Nannus hiemalis), 32. 



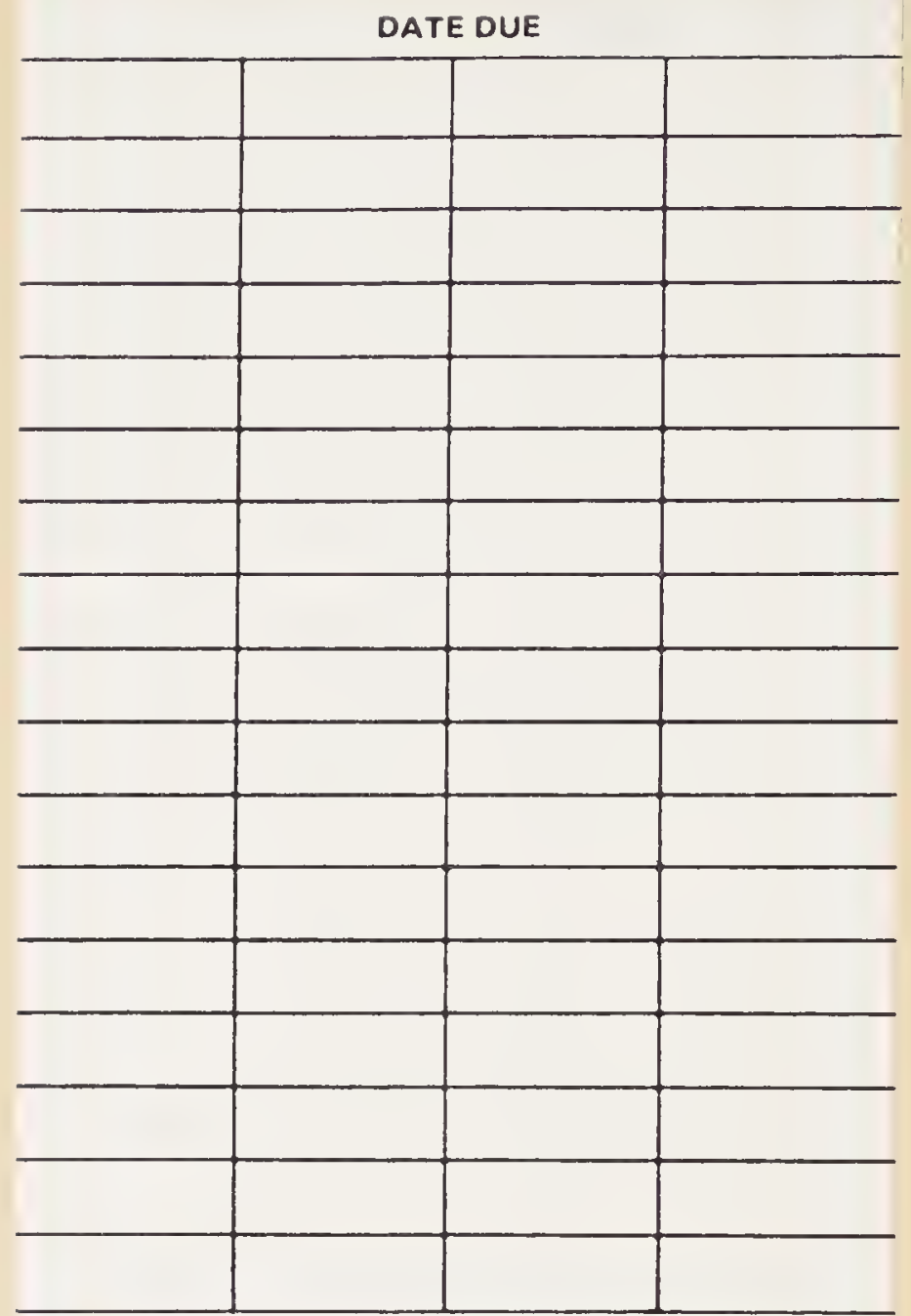

CARR MCLEAN, TORONTO FORM $* 38.297$ 


\section{QH $106 . T 781910$ \\ Townsend, Charles Wendel \\ A Labrador spring/ by Charles \\ 010101000 \\ |.|. \\ 0116300007519 \\ TRENT UNIVERSITY}

QH106 . T78 1910

Townsend, Charles Wende11,1859-

A Labrador spring 
$4 x$

की

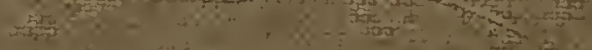

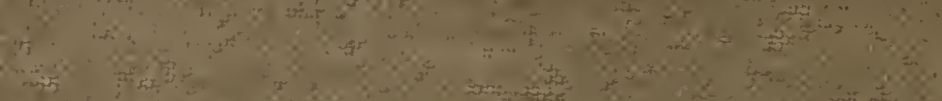

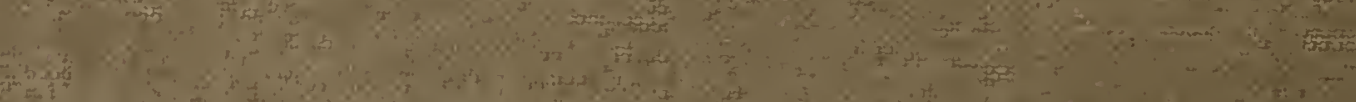

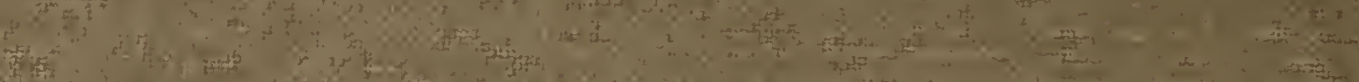

(5)

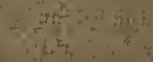

and 6)

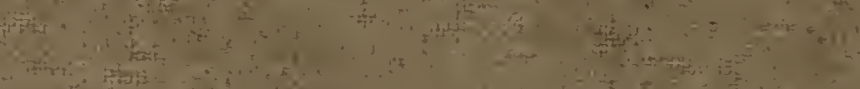
(n) स 1.. If

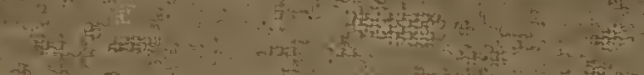
$\therefore$

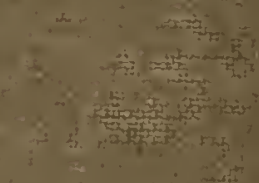

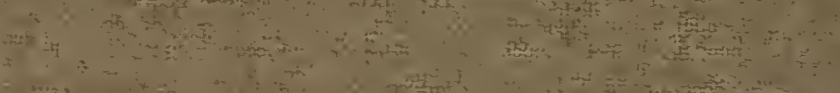

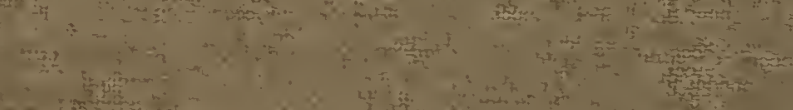

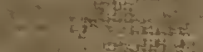

thing

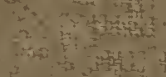

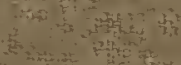

and

,

in

to

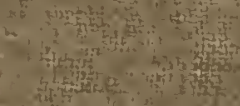

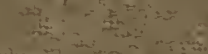

is

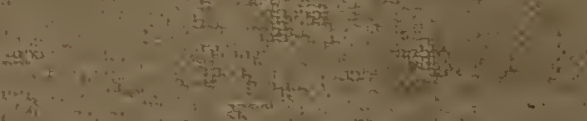

(n)

(1)

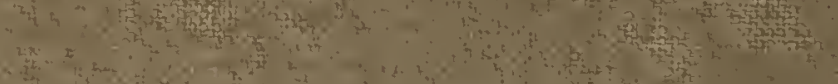

a

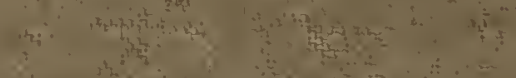

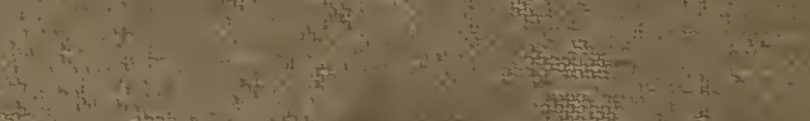

\%

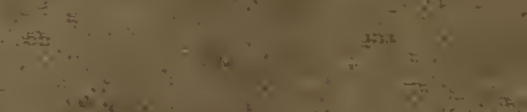

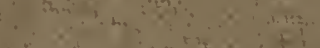

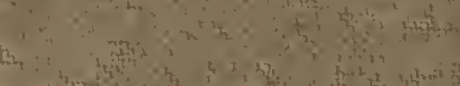

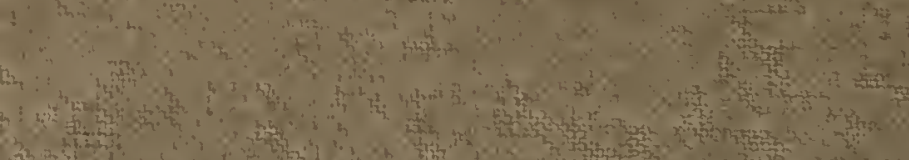
and

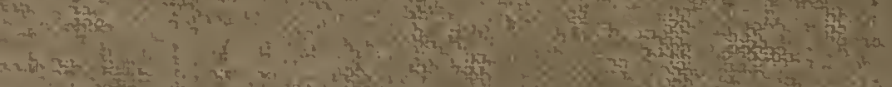
and

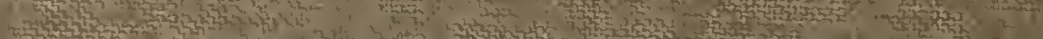
ingases 